TA7

E8

no.ERDC/GSL

TR-04-10

c.3

\section{LIBRARY}

USE ONLY ismil

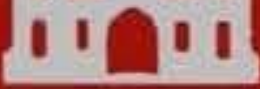

US Army Corps

of Engineers ${ }_{\circledast}$

Engineer Research and Development Center

\title{
Evaluation of Expedient Methods for Mitigating Dust on Helipads
}

Jeb S. Tingle, Andrew Harrison, and John F. Rushing

September 2004

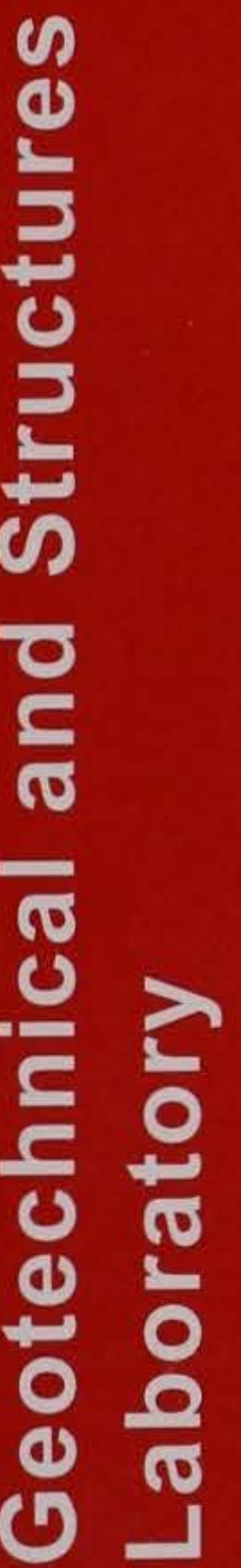


Evaluation of Expedient Methods for Mitigating Dust on Helipads

Jeb S. Tingle, Andrew Harrison, and John F. Rushing c. 3

Geotechnical and Structures Laboratory

U.S. Army Engineer Research and Development Center 3909 Halls Ferry Road

Vicksburg, MS 39180-6199

Final report

Approved for public release; distribution is unlimited 


\begin{abstract}
:
The U.S. Army Engineer Research and Development Center (ERDC) was tasked by the Marine Corps Systems Command to develop two dust control systems, one for expeditionary use on Forward Area Refueling Points (FARPs) and one for sustainment use on roads and other large area applications. The project consisted of the evaluation of various dust palliatives and application equipment under controlled laboratory conditions and during field tests. The products of this effort include equipment recommendations, palliative recommendations, and complete application guidance. This report addresses testing performed to evaluate commercial palliatives and palliative distribution systems for expeditionary use in constructing and maintaining FARP sites. Eighteen helipads were constructed at Marine Corps Air Station Yuma using both experimental and commercial palliatives for dust abatement. The application methods were principally topical (spray-on) and expeditionary in nature. Each helipad was subjected to $\mathrm{CH}-46$ rotary-wing aircraft traffic, and selected helipads were subjected to $\mathrm{CH}-53$ traffic. The helipads were evaluated based upon effectiveness in controlling dust, durability, foreign object damage (FOD) potential, and overall surface condition. Pertinent conclusions from the testing conducted are noted, and recommendations for selecting dust abatement methods and materials are provided.
\end{abstract}

DISCLAIMER: The contents of this report are not to be used for advertising, publication, or promotional purposes. Citation of trade names does not constitute an official endorsement or approval of the use of such commercial products. All product names and trademarks cited are the property of their respective owners. The findings of this report are not to be construed as an official Department of the Army position unless so designated by other authorized documents. 


\section{Contents}

Conversion Factors, Non-SI to SI Units of Measurement...................................

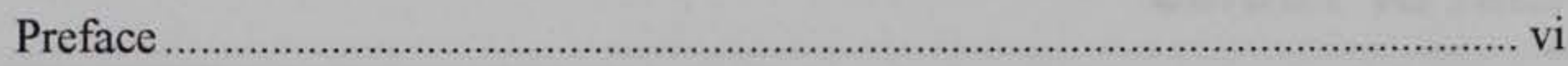

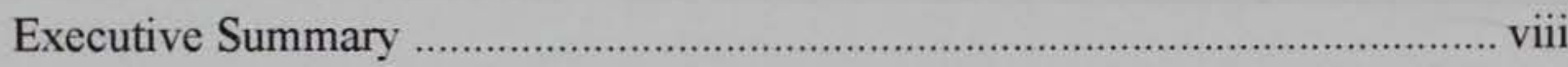

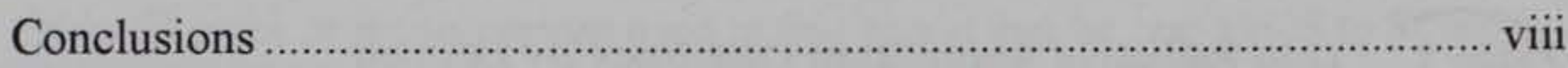

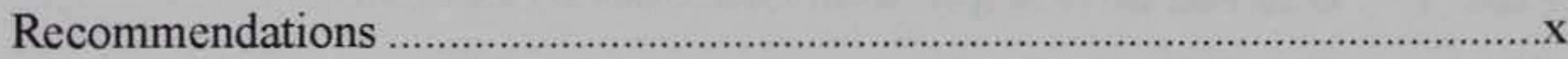

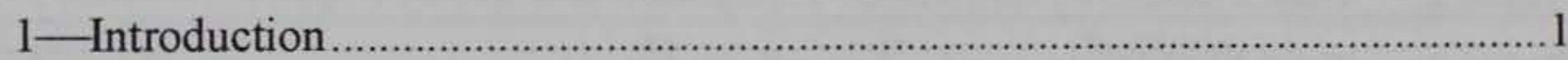

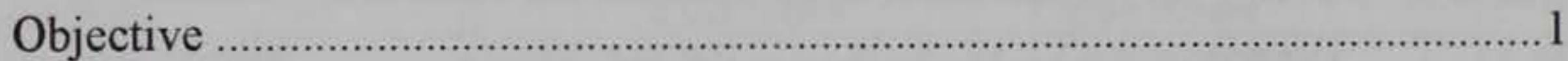

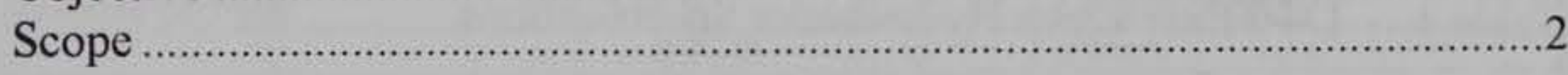

2- Laboratory Evaluation of Dust Palliatives ................................................... 3

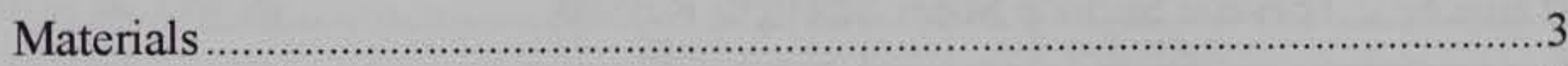

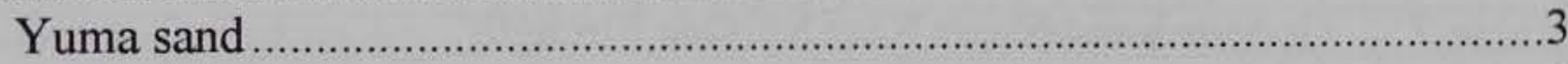

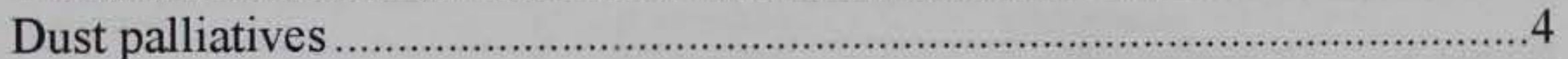

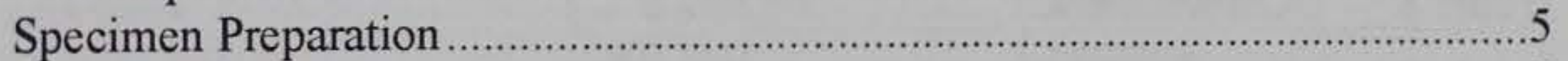

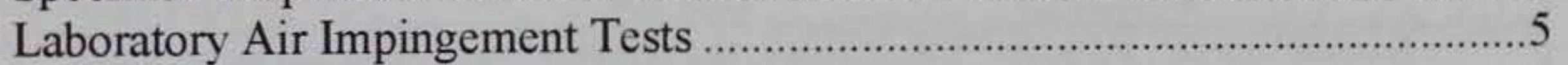

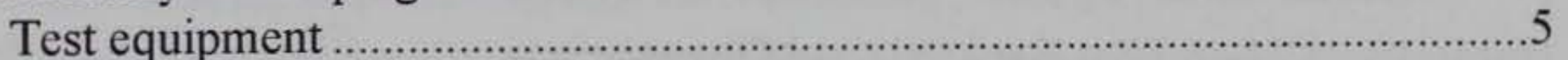

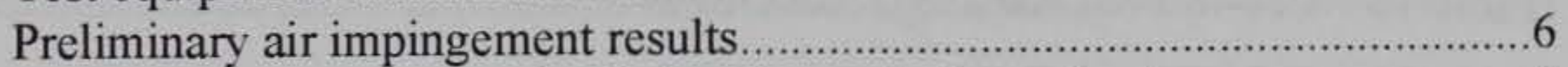

Air impingement results simulating Yuma field applications ..................... 7

3-Evaluation of Palliative Application Methods .......................................... 10

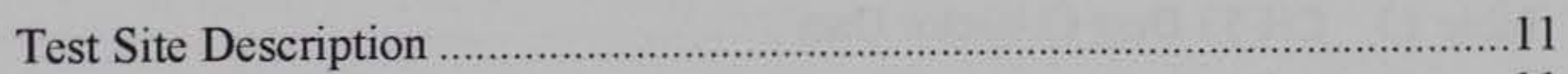

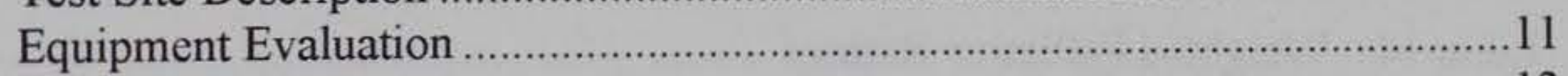

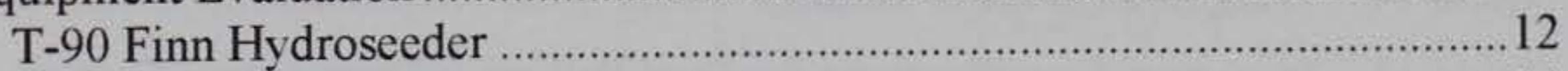

L-90 Easy Lawn Hydroseeder .....................................................................14

Marine Corps HMMWV Dust Abatement Vehicle (DAV) ........................14

Specifications on the MTVR

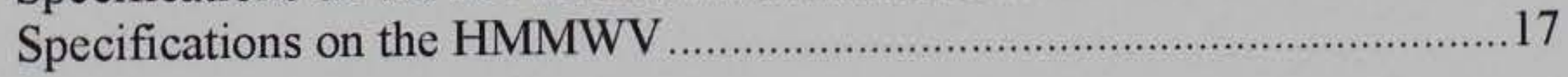

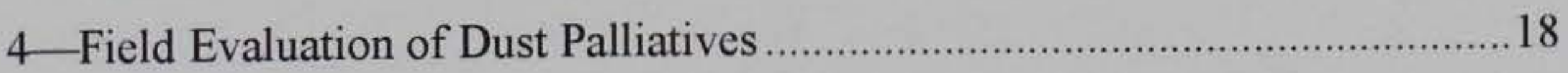

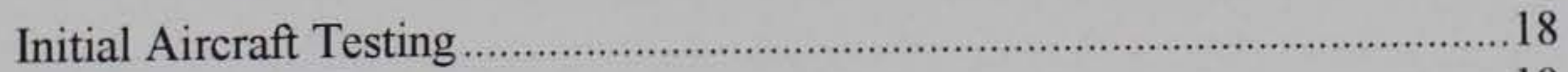

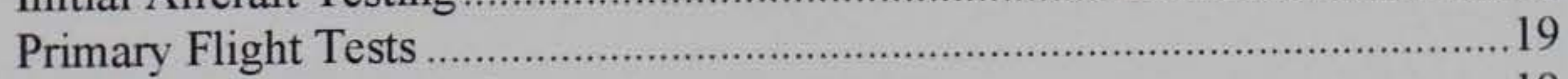

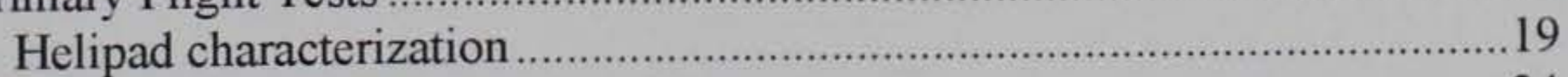

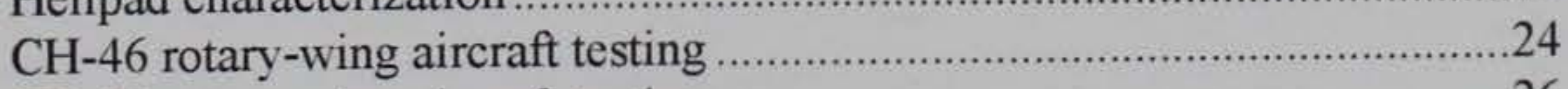

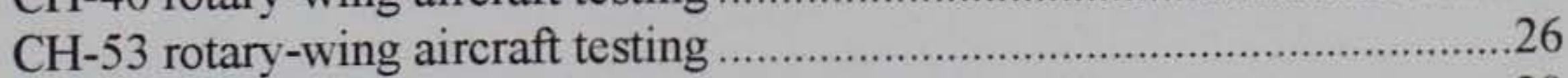

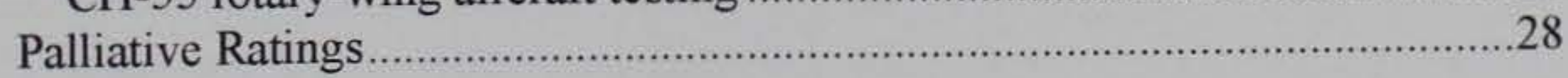




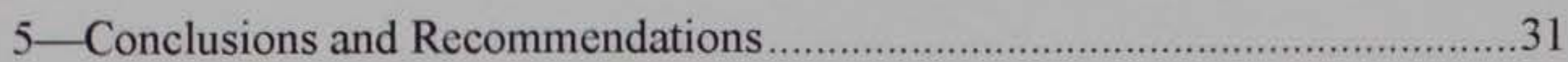

Conclusions

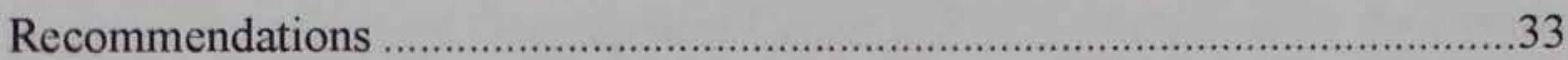

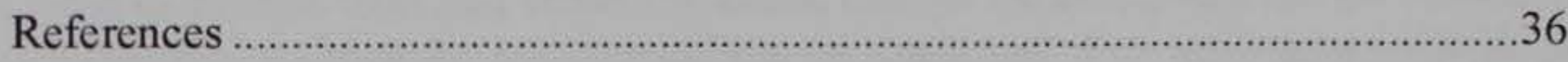

Figures 1-8

Photos 1-72

SF 298

\section{List of Tables}

Table 1. Dust Palliative Application Quantities By Helipad .............................9

Table 2. Dust Palliative Application Equipment and Time .............................12

Table 3. T-90 Finn Hydroseeder Specifications ............................................13

Table 4. L-90 Easy Lawn Hydroseeder Specifications ....................................15

Table 5. Pre-Test Visual Helipad Soil Surface Data .......................................20

Table 6. Torvane Surface Shear Strength Results ...........................................21

Table 7. Geonor Vane Shear Near Surface Strength ......................................22

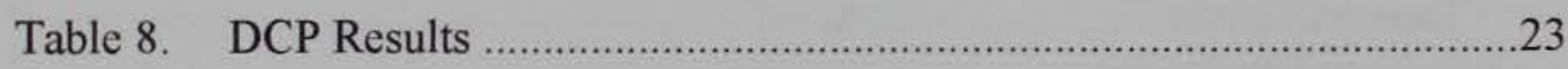

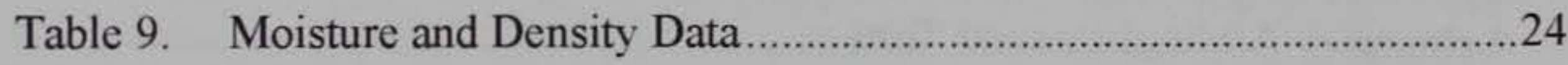

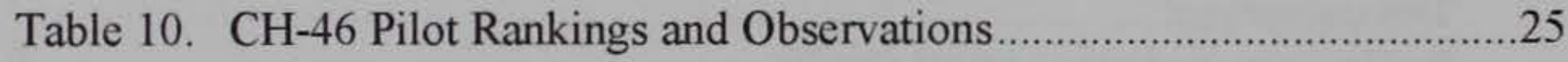

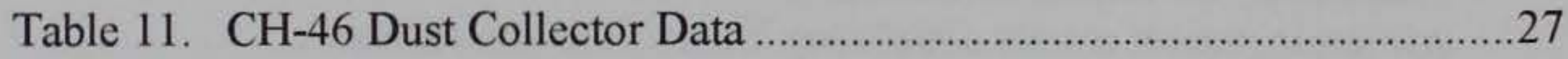

Table 12. CH-53 Pilot Rankings and Observations.......................................28

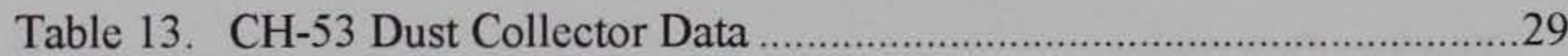

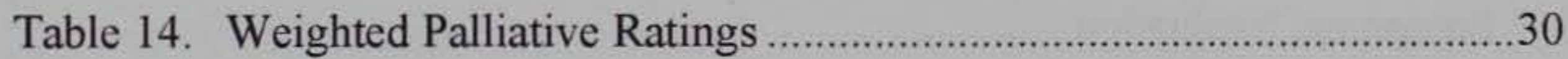

Table 15. Minimum Specifications for Dust Palliative Distribution System ......35 


\section{Conversion Factors, Non-SI to SI Units of Measurement}

Non-SI units of measurement used in this report can be converted to SI units as follows:

\begin{tabular}{||l|l|l||}
\hline \hline Multiply & \multicolumn{1}{l|}{ By } & To Obtain \\
\hline \hline cubic feet & 0.02831685 & cubic meters \\
\hline Fahrenheit degrees & $5 / 9$ & Celsius degrees \\
\hline feet & 0.3048 & meters \\
\hline gallons (U.S. liquid) & 3.785412 & liters \\
\hline $\begin{array}{l}\text { horsepower (550 foot-pounds } \\
\text { force) per second) }\end{array}$ & 745.6999 & watts \\
\hline inches & 25.4 & millimeters \\
\hline pounds (force) per square inch & 3.894757 & kilopascals \\
\hline pounds (mass) & 0.4535924 & kilograms \\
\hline square yards & 0.8361274 & square meters \\
\hline tons (short, 2000 lb) & 907.1847 & kilograms \\
\hline \hline $\begin{array}{l}\text { To obtain Celsius (C) temperature readings from Fahrenheit (F) readings, use the following } \\
\text { formula: C }=(5 / 9)(F-32) .\end{array}$ & \\
\hline
\end{tabular}




\section{Preface}

The purpose of this report is to present results from the evaluation of expedient methods for mitigating dust on helipads subjected to rotary-wing aircraft traffic. An expedient method, as defined in this experiment, is a dust abatement material or method that is rapidly applied using reduced logistical footprint equipment. The dust abatement materials and application methods must effectively control dust for at least 30 days. This report includes the evaluation of commercially available and experimental dust palliatives, as well as the evaluation of alternative methods for applying the products. Data are provided for the following:

a. Evaluation of commercially available dust palliatives for mitigating dust on helipads under rotary-wing traffic.

b. Evaluation of expeditionary palliative distribution techniques for rapid product application using reduced footprint technologies.

c. Selection of palliative application rates for topical treatment of helipads in expeditionary environments.

d. Selection of palliative dilution ratios for topical treatment of helipads in expeditionary environments.

Users of this report include the United States Marine Corps' Systems Command (MCSC), units charged with expedient helipad construction, and agencies assigned operations planning responsibilities.

The project described in this report is part of the Dust Abatement Program currently sponsored by Headquarters, U.S. Marine Corps Systems Command, Quantico, VA.

This publication was prepared by personnel from the U.S. Army Engineer Research and Development Center (ERDC), Geotechnical and Structures Laboratory (GSL), Vicksburg, MS. The findings and recommendations presented in this report are based upon a series of laboratory tests conducted at ERDC/GSL and field tests conducted at Marine Corps Air Station, Yuma, AZ, from January to March 2004. The research team consisted of Messrs. Jeb S. Tingle, Andrew Harrison, John F. Rushing, Timothy McCaffrey, Quint Mason, Roosevelt Felix, Chad Gartrell, Ernest Berney, and Thuan Nguyen, Airfield and Pavements 
Branch (APB), GSL. Messrs. Tingle, Harrison, and Rushing prepared this publication under the supervision of Mr. Don R. Alexander, Chief, APB, and Dr. David W. Pittman, Acting Director, GSL.

COL James R. Rowan, EN, was Commander and Executive Director of ERDC, and Dr. James R. Houston was Director.

Recommended changes for improving this publication in content and/or format should be submitted on DA Form 2028 (Recommended Changes to Publications and Blank Forms) and forwarded to Headquarters, U.S. Army Corps of Engineers, ATTN: CECW-EWS, Kingman Bldg, Rm 321, 7701 Telegraph Road, Alexandria, VA 22315. 


\section{Executive Summary}

The ERDC was tasked by the MCSC to develop two dust control systems, one for expeditionary use on Forward Area Refueling Points (FARPs) and one for sustainment use on roads and other large area applications. The project consisted of the evaluation of various dust palliatives and application equipment under controlled laboratory conditions and during field tests. The products of this effort include equipment recommendations, palliative recommendations, and complete application guidance. This report addresses testing performed to evaluate commercial palliatives and palliative distribution systems for expeditionary use in constructing and maintaining FARP sites. Eighteen helipads were constructed at MCAS Yuma using both experimental and commercial palliatives for dust abatement. The application methods were principally topical (spray-on) and expeditionary in nature. Each helipad was subjected to $\mathrm{CH}-46$ rotary-wing aircraft traffic, and selected helipads were subjected to $\mathrm{CH}-53$ traffic. The helipads were evaluated based upon effectiveness in controlling dust, durability, FOD potential, and overall surface condition. Pertinent conclusions from the testing conducted are noted below and recommendations for selecting dust abatement methods and materials are provided in the following text.

\section{Conclusions}

The following conclusions were derived from the application and testing of selected dust palliatives from February to March 2004:

a. The commercial water trucks and distributors used to apply the products during the experiment were effective in agitating and distributing a uniform product. However, the cost and poor mobility of the vehicles make them unsuitable for extended military use.

$b$. The agricultural trailer with flotation tires demonstrated very good mobility, but did not include an agitation system for producing a consistent product and required a tow vehicle. In addition, the uniformity of product application was poor.

c. The two hydroseeders used during the experiment provided three methods of distribution, each useful in applying the products. The poor mobility of the hydroseeders due to the weight of the trailer-mounted 
systems reduced their overall effectiveness. However, the devices provided good agitation of the product and excellent uniformity of product distribution over the helipad. These devices provided a rapid means of topically distributing dust palliatives in an expeditionary environment.

d. The dust abatement vehicle (DAV) required the greatest time and manpower for product application of the methods evaluated. The DAV system required calibration of the drop spreader for dry palliative distribution due to the fineness of the dry powder. The system required additional manpower for hand raking the dry palliative into the helipad surface and guiding the vehicle during product distribution. The application of the water-polymer emulsion was time consuming due to the limitations of the spray nozzles used and the requirement to refill the tank. The DAV system was limited in the amount of water it could carry due to axle load limitations and will require additional assets such as an MTVR with water containers to provide the amount of water required for the Tri-PAM process.

e. The NRL experimental products and Soiltac $\mathbb{R}$ were effective in controlling the dust compared to the untreated helipad sections immediately after application with 3 days curing.

f. The following products performed well during testing of the helipads

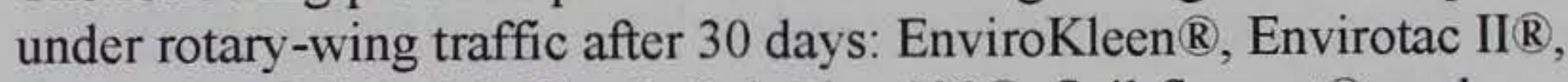

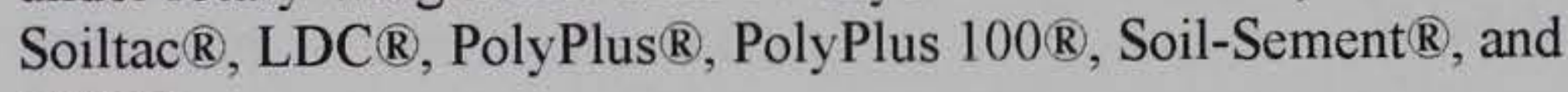
LDCR.

g. ECO $110 \AA$ and Tri-PAM were moderately effective in controlling the dust under helicopter traffic after 30 days.

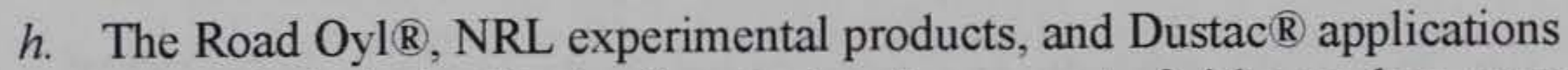
were relatively ineffective in reducing the amount of airborne dust generated during rotary-wing aircraft operations after 30 days. However, these products were applied at very low application rates, which impacted their effectiveness. The NRL products and Road Oyl were effectively leached from the helipad during a 0.5 -in. rainfall event and were ineffective in controlling dust in the subsequent test cycle.

i. Topical application of dust palliatives is typical of an expeditionary application where construction equipment is nonexistent or limited. Products may perform better using more rigorous construction processes and equipment.

j. Crust forming products tended to provide effective dust abatement under limited traffic, but light applications less than 0.5 gal per square yard broke up during flight operations producing a potential FOD problem.

k. Tri-PAM, PolyPlus ${ }^{\circledR}$, and PolyPlus $100 \AA$ provided varying degrees of effectiveness controlled by the intimacy of the mixing process and the 
formation of polymer nodules binding the soil particles together. These products, polyacrylamides, are water absorbing and produced a very tacky surface following a 0.5 -in. rainfall event.

\section{Recommendations}

Based on equipment testing completed by ERDC at the WES and field experience obtained during the exercise, the following recommendations are provided:

a. The palliative distribution system must be maneuverable in soft sand conditions. This requirement dictates that the system be either a selfpropelled all wheel drive system, a trailer-mounted high flotation towable system that can be towed by a MTVR or TRAM, or a skidmounted system that can be put on a high flotation trailer or on the back of the MTVR.

b. The distribution system should have multiple methods for applying dust palliatives. These methods include a spray hose system, a tower gun system, and a distribution bar system. Each system will have applications in the theater, including the distribution bar, which was evaluated at WES by ERDC personnel. The distribution bar will be extremely useful where site mobility permits its use and on larger areas such as roads and airfields.

c. The hydroseeder type equipment is recommended for the distribution system with the minimum requirements indicated in Table 15 . However, the requirements noted in Table 15 should be evaluated for $\mathrm{CH}-53$ and/or C-130 compatibility.

d. Due to the difficulty in securing repair/replacement parts for COTS equipment, it is recommended that two sets of nozzles, two sets of hose clamps and couplings, a hose repair kit, pump parts, and a small engine repair kit are included in the system procured. A toolbox should be included to store the extra parts.

$e$. Both the towed and skid-mounted application systems require a means of transferring the palliatives from 275 -gal totes into the system. Thus, a small pump with $20 \mathrm{ft}$ of 2 -in. hose on each end is recommended for inclusion in the system to transfer palliative from shipping containers to the application equipment. Include an in-line quick-connect ball valve on the suction end of the hose.

f. The systems evaluated included rudimentary gages of remaining product. An improved system capable of measuring within 25 gal of product should be included in the system selected. The ability to estimate the amount of product remaining is essential to achieving the desired application rate with limited material quantities. 
g. The pulverizer systems commonly included on some hydroseeders are not necessary unless they also serve to agitate the material contained within the tank. As noted, a mechanical system is preferred due to the viscosity of the palliatives evaluated.

$h$. The frame of the trailer or skid-mounted system must be strong enough to support the weight of the loaded system and allow sling loading of the system for rotary-wing transport. The system should include adequate tie-down strong points for sling loading and mounting on an MTVR.

i. It is further recommended that a minimum of two 900 -gal towed systems and two 1,200-gal skid-mounted systems be procured with the recommended amounts of product for immediate fielding. Feedback from designated units should be used to refine system parameters.

$j$. The COTS products were commonly shipped in 275-gal totes. It is recommended that the products procured should be packaged in 275-gal totes according to DoD shipping standards as a compromise between capacity and logistical footprint. The possibility of using 200 -gal totes should be pursued to minimize product waste.

k. Based upon the limited traffic applied to the helipads and pilot feedback, it is recommended that the USMC procure EnviroKleen $\mathbb{R}$ and apply the undiluted product "neat" at a minimum application rate of 0.36 gsy and a maximum application rate for sandy soils of $0.5 \mathrm{gsy}$. Gray water and salt water may be used for dilution.

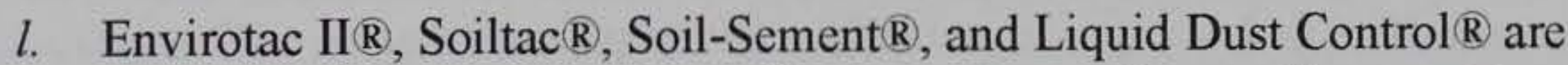
recommended for use as dust palliatives where a firm surface crust is desired. The concentrated product (approximately 50 percent solids) should be diluted with 2 parts water to 1 part concentrate or a $2: 1$ dilution ratio. The diluted product should be applied at a minimum application rate of $0.65 \mathrm{gsy}$.

$m$. It is further recommended that the hydroseeder distribution systems and the dust palliatives recommended be fielded to units for evaluation and feedback. It is recommended that MCSC monitor the units' feedback and lessons learned to develop long-term solutions for dust control on FARP sites.

This report includes the results of laboratory and field evaluations of selected dust abatement products and distribution equipment for rapid dust control of expeditionary helipads. The conclusions and recommendations provided in this report serve as guidance for rapidly mitigating dust generated by rotary-wing aircraft in an expeditionary environment with reduced logistical footprint products and equipment. The laboratory tests are described in Chapter 2, and the equipment evaluation is discussed in Chapter 3 of this report. A detailed description of the field tests conducted at MCAS Yuma on 18 helipads is documented in Chapter 4. Conclusions and recommendations are presented in Chapter 5. 


\section{Introduction}

The U.S. military was plagued by fugitive dust during Operations Enduring Freedom and Iraqi Freedom. The generation of airborne dust during aircraft operations significantly impacted both fixed-wing and rotary-wing aircraft missions. Rotary-wing aircraft often experienced "Brown Out" conditions in which the density of airborne dust was such that the pilots lost site of the ground resulting in hazardous operating conditions. Aircraft and personnel were lost due to accidents resulting from "Brown Out" conditions. In addition, the widespread accumulation of dust during ground vehicle operations and in base camps adversely impacted the ability of military personnel to effectively conduct combat operations.

The U.S. Army Engineer Research and Development Center (ERDC) was tasked by the U.S. Marine Corps Systems Command (MCSC) to develop two dust control systems, one for expeditionary use on Forward Area Refueling Points (FARPs) and one for sustainment use on roads and other large area applications. The project consists of the evaluation of various dust palliatives and application equipment under controlled laboratory conditions and during field tests. The products of this effort include equipment recommendations, palliative recommendations, and complete application guidance. This report addresses testing performed to evaluate commercial palliatives and palliative distribution systems for expeditionary use in constructing and maintaining FARP sites.

\section{Objective}

The primary objectives of this phase of the evaluation were to develop recommendations for dust palliatives and distribution equipment alternatives for applying products in an expeditionary environment. This report provides data for the following:

a. Evaluating commercially available dust palliatives for mitigating dust on helipads under rotary-wing traffic.

b. Evaluating expeditionary palliative distribution techniques for rapid product application using reduced footprint technologies.

c. Selection of palliative application rates for topical treatment of helipads in expeditionary environments. 
d. Selection of palliative dilution ratios for topical treatment of helipads in expeditionary environments.

The testing initiated in this evaluation represents the first phase of a comprehensive dust abatement program designed to develop two dust control systems, one for expeditionary use on Forward Area Refueling Points (FARPs) and one for sustainment use on roads and other large area applications. The results of the overall program will provide the USMC with the equipment, products, and criteria for mitigating dust in the theater of operations.

\section{Scope}

This phase of the program consisted of the laboratory evaluation of commercially available dust palliatives, the field evaluation of dust palliatives, and the field evaluation of palliative application equipment. The laboratory component of this evaluation was used to evaluate the performance of different products and combinations of products under simulated helipad conditions. These data were used to screen products for future field experiments and to evaluate the performance of different products, multiple dilution ratios, and selected application rates. Commercial application equipment were evaluated under controlled conditions at the Waterways Experiment Station and individual systems were selected for field evaluation in conjunction with a "Desert Talon" exercise being conducted at Marine Corps Air Station (MCAS) Yuma. Seventeen helipads were treated with different dust palliatives during the Desert Talon exercise to evaluate the performance of different palliatives and application equipment under field conditions. Unfortunately, adverse weather conditions prevented the complete testing of all of the helipads immediately after application. However, each helipad was subjected to both $\mathrm{CH}-46$ and $\mathrm{CH}-53$ helicopter landings after the helipads were permitted to dry for a period of approximately 30 days. The results of the laboratory tests conducted on the commercial dust palliatives, the field evaluation of application equipment, and the flight tests of the helipads at MCAS Yuma are presented in this report. The laboratory results are described in Chapter 2, and the evaluation of application equipment is described in Chapter 3. Chapter 4 summarizes the results of the rotary-wing flight tests conducted on the treated helipads at MCAS Yuma. Conclusions and recommendations for expeditionary helipad dust abatement methods and materials are provided in Chapter 5. 


\section{Laboratory Evaluation of Dust Palliatives}

There are numerous commercially available products currently marketed for dust control and/or soil stabilization. However, case studies and literature report mixed results using many of these products. The absence of standardized test procedures for evaluating products and the lack of unbiased quantitative performance results inhibits thoughtful product selections. In this investigation, experimental laboratory procedures were developed for the testing and evaluation of dust palliatives in order to provide a means of rapidly comparing product effectiveness under simulated conditions without the high cost of performing field demonstrations. The objective of the laboratory experiment was to determine the effectiveness of commercial dust palliatives at resisting wind erosion and dust cloud formation under simulated helicopter rotor wash on unsurfaced soils. The laboratory study was divided into two parts. First, numerous products touted as being effective at controlling airborne dust were tested during the period from December 2003 to January 2004. These included various application rates of polymer emulsions, lignosulfonates, and the polyacrylamide-based Tri-PAM developed by the U.S. Marine Corps Warfighting Laboratory (MCWL). The second phase of the laboratory study was designed to replicate the application rates of products used in the field demonstration performed between January and February 2004 in which helipads were constructed at the MCAS in Yuma, AZ.

\section{Materials}

\section{Yuma sand}

The soil used to prepare the laboratory specimens was obtained from aeolian deposited dunes near Yuma, Arizona. This sand, referred to hereafter as Yuma sand, was selected for its small particle sizes prone to dust formation and the presence of a locally available stockpile. The gradation curve for this sand is shown in Figure 1. The sand contained no gravel-sized particles and less than 7 percent minus No. 200 U.S. standard sieve size material. It was classified as a poorly graded silty sand (SP-SM) according to the Unified Soil Classification System. 


\section{Dust palliatives}

A market survey of available dust abatement products was conducted to identify products for expeditionary helipad dust mitigation. Products were selected based upon prior experience and documented case studies. The products tested during this investigation can be divided into several categories, acrylic polymer emulsions, lignosulfonates, synthetic oils, polyacrylamides, and organic sugars.

The emulsified acrylic polymers and copolymers included LDC (liquid dust control), Envirotac II, and Soiltac. These products typically contain approximately 40 percent solid particles by weight of emulsion. They are capable of being diluted with water in the emulsion form and are intended to be sprayed onto the soil surface. Water evaporation promotes the coalescence of the polymer chains and the formation of a binding network in the soil that provides particle cohesion and strength.

Dustac, Dustac 100 and Road Oyl are classified as lignosulfonates. They are naturally derived from tree rosins and serve as binding agents in soils. Road Oyl and Dustac are shipped in an emulsified state while Dustac 100 is a fine powder, intended to be mixed with water prior to application.

EK-35 and EnviroKleen are both products containing synthetic fluids and rosins that create a reworkable binder in the soil. They are insoluble in water and designed for "neat" application. These palliatives do not dry or cure with time.

Tri-PAM is a development of the MCWL using a polyacrylamide (PAM) based mixture of materials for water retention and soil binding. The highly absorbent material is applied as a powder and then sprayed with a diluted PAM emulsion for activation. Samples were prepared as recommended by the MCWL using $6 \mathrm{~g}$ of PAM, $1 \mathrm{~g}$ of super absorbent, and $1 \mathrm{~g}$ of aluminum chlorohydrate per square foot followed by an application of $0.6 \mathrm{gal} / \mathrm{sq}_{\mathrm{yd}} \mathrm{d}^{1}$ of the PAM emulsion diluted to 0.05 percent by weight in water. Testing was also performed on individual components of the Tri-PAM palliative for observation. A modified version of the PAM powder with added calcium was evaluated as an alternative dust palliative.

The Navy Research Laboratory (NRL) product is an experimental product composed of a polysaccharide solution with an added surfactant for dispersion and penetration. It is water soluble and therefore susceptible to leaching from the soil surface after exposure to precipitation. The product is designed for short duration dust control in arid conditions and is biodegradable.

\footnotetext{
${ }^{1}$ A table of factors for converting non-SI units of measurement to SI units is presented on page $\mathrm{v}$.
} 


\section{Specimen Preparation}

During previous investigations involving the evaluation of soil stabilization products, a rather simple and reproducible method of preparing laboratory specimens with chemical additives was developed (Santoni et al. 2002). For the initial laboratory evaluation of this program, a moisture content of 13 percent was selected in order to effectively mold the essentially cohesionless Yuma sand. However, for the polymer emulsions and lignosulfonates, a moisture content of 10 percent had to be used due to the lubricating effects of the materials in the sand and the shift of the moisture density curve to the dry side. At the target moisture content of 13 percent, pore water was exuded from the specimens during compaction. The Yuma sand was first oven dried to remove all moisture. Each palliative was then added in the desired concentration to $7000 \mathrm{~g}$ of Yuma sand and mixed thoroughly with an electric drill and rotary mixing bit (Photo 1) Any additional water needed to reach optimum moisture content was mixed into the sand prior to palliative addition. Once the sand, additive and water were thoroughly mixed, $2,200 \mathrm{~g}$ of treated material was weighed and placed into the mold. The cylindrical samples were compacted using a Pine ${ }^{\circledR}$ gyratory compaction machine using a 4-in.-diam mold at a ram pressure of $870 \mathrm{kPa}$ and 90 revolutions in order to produce the same density as ASTM D 1557 (Photo 2). Three 4-in.-diam by 6 -in.-high cylindrical specimens, each containing 2,200 $\mathrm{g}$ of treated soil, were made for each test. This method of sample preparation allowed for the rapid production of a large number of samples with consistent properties. After compaction, the samples were extruded from the mold, weighed, and immediately placed under curing lamps at $120^{\circ} \mathrm{F}$ for 4 or $24 \mathrm{hr}$ to simulate desert ground surface temperature conditions (Photo 3 ) and to investigate the effect of curing time on product effectiveness.

\section{Laboratory Air Impingement Tests}

\section{Test equipment}

The design for the laboratory evaluation was based upon the work of Styron and Eaves (1973) and Grau (1993). The primary laboratory tool used for evaluating dust control products for helipads was an air impingement apparatus. The air impingement device subjects samples to various wind velocities to subjectively determine the effectiveness of the dust palliative under simulated rotor wash velocities. The results, however, were not quantified in the original studies according to their technique. For this evaluation, soil weight loss due to surface erosion was used to quantify each material's effectiveness at controlling dust.

The air impingement device used in this evaluation is shown in Photo 4. The device generates wind velocities of up to $150 \mathrm{mph}$ through an electric blower with a modified nozzle thermally cast from schedule 40,3 -in. PVC pipe. The pipe was molded to create a rectangular-shaped opening 4.50 -in.-wide and 0.625 -in.-high at the exit. The $150 \mathrm{mph}$ wind speed was selected to simulate severe conditions created under an approaching helicopter. A 4-in. return flow duct circulates the air along with any suspended particles and relieves pressure in 
the chamber. An injection system introduces Ottawa sand into the air stream just below the blower to accelerate the surface erosion and simulate the "sand blasting" effect that existing dust particles may have in a helicopter's rotor wash. This sand was chosen for its narrow size distribution to enhance consistency in measurements. An air hose is connected to the sand injector with a pressure of 5 psi to overcome the pressure developed within the pipe. Samples are loaded through a hole in the center of the bottom plate and positioned to the desired height using the adjustable pedestal for testing. Upon curing, the specimens were weighed and placed in the testing chamber. They were then subjected to $10 \mathrm{sec}$ of $150 \mathrm{mph}$ wind with $200 \mathrm{~g}$ of injected Ottawa sand and then reweighed. Those showing the least weight loss during the testing were deemed to be most effective as dust palliatives. The air impingement test was designed to provide a relatively harsh environment such that the results of the test would clearly distinguish between the performance of different products.

\section{Preliminary air impingement results}

A preliminary series of specimens was prepared to evaluate selected commercial dust palliatives using the air impingement device while refining the procedures used to perform the impingement test. For the preliminary evaluation, the water-soluble products were evaluated at three different concentrations to determine appropriate dilution ratios for field application. These products were applied "neat" at $0.5 \mathrm{gal} / \mathrm{yd}^{2}$, diluted $2: 1$ (water:palliative) and applied at $0.5 \mathrm{gal} / \mathrm{yd}^{2}$, and diluted $2: 1$ and applied at $0.25 \mathrm{gal} / \mathrm{yd}^{2}$. The results of the preliminary air impingement tests for the commercial palliatives are shown graphically in Figures 2 and 3 for the 4-hr and 24-hr cured specimens, respectively. Each test represents an average erosion value or weight loss of three specimens.

The untreated specimens were observed to have the most severe surface erosion during testing (Photo 5 ). All of the products evaluated did provide some dust suppression, but the effectiveness of the material was dependent on both the chemical type and formulation. The untreated control sample had a higher erosion potential at longer curing times due to the evaporation of water and loss of capillary tension binding sand particles. This was not the case, however, with the acrylic polymer emulsions that were tested (Photo 6). The acrylic polymer emulsions performed more effectively at longer curing times due to the emulsion particle coalescence and film formation that occurs with the evaporation of excess water. For the 4-hr cured specimens, only the high concentrations of emulsions were able to exhibit strong enough binding properties to be effective at controlling wind erosion. These results may serve not only as an indicator of the long-term durability of these products under natural environmental conditions, but also may indicate the necessity to allow the curing process to take place before effective dust control can be expected.

The lignosulfonates and oil-based products tended to lose effectiveness with additional curing times. The samples containing Road Oyl and both Dustac products did exhibit significant binding effects but these effects were very concentration dependent. Road Oyl had excellent effectiveness but only at concentrations 
higher than that desired for expeditionary applications with limited material quantities. The two Dustac products were as effective as the polymer emulsions with $24 \mathrm{hr}$ of curing, but they displayed a hard surface crust covering a soft, moist sublayer that could possibly be ineffective in field conditions where even light traffic may exist. These products, however, were the best performing materials when tested after $4 \mathrm{hr}$ of curing. The samples containing EK-35 and Envirokleen, the oil-based products, displayed little binding properties and were relatively ineffective during laboratory testing (Photo 7). The Envirokleen samples did perform better than those treated with EK-35 for both 4- and 24-hr cure times in Yuma sand. The samples were very soft and appeared to have very little moisture or solvent loss during the times exposed to the elevated temperatures. The performance mechanism for these products was noticeably different than the other products in the evaluation. These oil-based products appear to lubricate and produce agglomeration between particles without producing a brittle physical bond like the other products. Thus, the air impingement test may not adequately reflect the erosion resistance of these products since the specimens didn't become brittle and were relatively fragile.

During the laboratory phase of the evaluation, the Marine Corps Warfighting Laboratory (MCWL) provided samples of the raw materials used to produce the "Tri-PAM" product. Specimens of Tri-PAM and each of its individual components were tested to determine the origin of the dust control. Quantities of individual components were used to replicate those of the original Tri-PAM formulation. The results of the 4-hr and $24-\mathrm{hr}$ cured specimens are shown in Figures 4 and 5, respectively. Tri-PAM was observed to reduce the wind surface erosion by approximately 50 percent compared to the control specimens for both 4- and 24-hr curing times (Photo 8). Further investigation revealed that the powdered PAM contributes to most of the Tri-PAM effectiveness. Samples mixed with the PAM emulsion were relatively ineffective in the laboratory tests probably due to the highly diluted nature of the emulsion. Samples made with the suggested quantities of the super absorbent material alone could not be tested due to the instability of the sample from localized swelling. These samples exhibited no binding effects and were highly cracked. The samples containing only the powdered PAM actually outperformed the Tri-PAM, especially after $24 \mathrm{hr}$ of curing. The reformulated powder containing calcium was ineffective and had a weight loss value similar to the control. The super absorber material, like the oilbased products, may not be adequately characterized by the air impingement test due to its primary mechanism of water retention. In the field, the ability to retain water in the soil in a desert environment may provide additional stability to the surface material.

\section{Air impingement results simulating Yuma field applications}

In order to more accurately evaluate the laboratory screening process, additional laboratory specimens were prepared with the dilution ratios and application rates that were applied in the field demonstration in Yuma, AZ. These products and amounts are listed in Table 1. A penetration depth of 1 in. was assumed for determining the product quantities to be used in preparing the laboratory specimens. The specimens were molded and compacted as described previously. For 
the evaluation of the simulated field applications, the specimens were placed under the curing lamps at $120^{\circ} \mathrm{F}$ for $24 \mathrm{hr}$ before testing to ensure complete curing. The testing procedure remained the same as the one described previously. The average weight loss of the three replicate specimens was determined and compared to the untreated specimen results. The untreated specimens were prepared with 6 percent water in order to obtain a free-standing sample after compaction. Figures 6 and 7 show the weight loss of the recreated helipads after testing.

Note that the dilution ratios and application rates used in the field were not identical for different products for direct comparison. This was due to the joint nature of the testing in Yuma, where multiple agencies with different objectives were responsible for applying different commercial and experimental palliatives. The specimens are divided into groups based upon the application rate applied to the helipads. The products with low product concentrations, less than $0.5 \mathrm{gsy}$, were evaluated as a truly expeditionary capability, where the application rate was based upon the minimum amount of product required to provide acceptable dust abatement based upon the preliminary laboratory testing. These expeditionary application rates and dilution ratios were expected to display the worst performance of all tested since they contained less product. The laboratory specimens comprised of some of these products at the expeditionary application rates did not significantly reduce the amount of erosion or weight loss during the air impingement testing. Both of the Dustac applications, the Road Oyl, and the two EnviroKleen applications had weight loss values similar to the control samples. The Liquid Dust Control and SoilTac B applications were the only products effective at such low concentrations. Again, the oil-based products may not be adequately represented under the air impingement tests since their performance mechanism does not include the formation of a physically bonded crust.

Three products were tested at medium application rates, greater than 0.5 gsy and less than $0.9 \mathrm{gsy}$. The two polymer emulsions, Envirotac B and Soil-Sement, were both effective in resisting the erosion under the air impingement tests at these concentrations. The NRL B specimens did not exhibit effective dust control in the middle range of application rates.

Specimens with application rates greater than 0.9 gal per square yard were considered to have high application rates. These application rates were considered high due to the amount of logistics required to treat helipads in the field. These were expected to produce the most effective dust abatement. The three polyacrylamide-based products did not follow this trend. Samples created from each of the variations were unstable due to the localized expansion of the super absorbent material and subsequent cracking. Thus, the obvious effect of the super absorbent material upon the specimens impacted the test results for the TriPAM and PolyPlus specimens. As noted the air impingement test may not be capable of adequately evaluating these products due to their performance mechanism being a combination of both near-surface water retention and physical bonding. The Soiltac A and Envirotac A specimens were the most effective of those tested. They had very little surface erosion from the air impingement test. The NRL A sample was also relatively effective and displayed its concentration dependence on dust palliation. 
Of the specimens tested using the air impingement device, the acrylic polymer emulsions performed best, significantly reducing the dust at low concentrations. The products containing lignosulfonates have little effectiveness at controlling dust for this soil type. These include the Dustac and Road Oyl products. The polyacrylamide products performed very poorly during this test but mostly from the low density stemming from desiccation of the compacted samples. Under alternate sample preparation techniques, they would be expected to be somewhat effective. The NRL formulation does seem to have soil binding properties that reduce dust emission at higher concentrations. The sample prepared with EnviroKleen had little resistance to the testing procedure. As noted the air impingement test procedure may not serve as an indicator of the effectiveness of the oil-based products and the products containing water retention additives like super absorbers and water-absorbing polyacrylamides. While the PAM products create some physical bonding and retain moisture within the sample, the bonding matrix is not uniform and results in isolated nodules of strong material surrounded by unbonded sand particles that may erode as shown in Photo 8. Thus, some surface erosion can be expected where the treatment matrix is inadequate.

\begin{tabular}{|c|c|c|c|c|c|c|}
\hline \multicolumn{7}{|c|}{$\begin{array}{l}\text { Table } 1 \\
\text { Dust Palliative Application Quantities by Helipad }\end{array}$} \\
\hline \multirow[b]{2}{*}{ Product } & \multirow{2}{*}{$\begin{array}{l}\text { Helipad } \\
\text { Number } \\
\text { (Fig. 6) } \\
\end{array}$} & \multicolumn{3}{|c|}{ Additive Amounts, gal } & \multirow{2}{*}{\begin{tabular}{l|} 
Application \\
Rate, \\
gsy
\end{tabular}} & \multirow{2}{*}{$\begin{array}{l}\text { CH-46 } \\
\text { Traffic } \\
\text { 21-Jan-04 } \\
\end{array}$} \\
\hline & & Product & Water & $\begin{array}{l}\text { Total } \\
\text { Applied } \\
\end{array}$ & & \\
\hline PolyPlus 100 & 1 & $\begin{array}{l}400 \mathrm{lb} \text { or } 44.4 \mathrm{gal} \\
4.4 \mathrm{gal} \text { of Emulsion }\end{array}$ & 1646 & 1694 & 1.02 & 0 \\
\hline PolyPlus & 2 & $\begin{array}{l}400 \mathrm{lb} \text { or } 44.4 \mathrm{gal} \\
4.4 \mathrm{gal} \text { of Emulsion }\end{array}$ & 1860 & 1909 & 1.15 & 0 \\
\hline Tri-PAM & 3 & $\begin{array}{l}400 \mathrm{lb} \text { or } 44.4 \mathrm{gal} \\
4.4 \mathrm{gal} \text { of Emulsion }\end{array}$ & 1996 & 2044 & 1.23 & 0 \\
\hline Envirotac A & 4 & 400 & 1200 & 1600 & 0.96 & 3 \\
\hline Soiltac A & 5 & 598 & 1661 & 2259 & 1.36 & 3 \\
\hline Soiltac B & 6 & 299 & 532 & 831 & 0.50 & 3 \\
\hline Envirotac B & 7 & 400 & 700 & 1100 & 0.66 & 3 \\
\hline ECO 110 & 8 & 275 & 1000 & 1275 & 0.77 & 0 \\
\hline LDC & 9 & 250 & 600 & 850 & 0.51 & 0 \\
\hline NRLA & 10 & 200 & 1400 & 1600 & 0.96 & 3 \\
\hline NRL B & 11 & 130 & 870 & 1000 & 0.60 & 4 \\
\hline Road Oyl & 12 & 165 & 665 & 830 & 0.50 & 0 \\
\hline Envirokleen B & 13 & 475 & 0 & 475 & 0.29 & 0 \\
\hline Dustac A & 14 & 140 & 691 & 831 & 0.50 & 0 \\
\hline Envirokleen A & 15 & 850 & 0 & 850 & 0.51 & 0 \\
\hline Soil-Sement & 16 & 240 & 960 & 1200 & 0.72 & 0 \\
\hline Dustac B & 17 & 70 & 761 & 831 & 0.50 & 0 \\
\hline Untreated & 18 & 0 & 0 & 0 & 0.00 & 5 \\
\hline Wet Control & 19 & 0 & TBD & TBD & TBD & 0 \\
\hline \multicolumn{2}{|c|}{ Range of Values: } & 48.8 to 850 & 0 to 1996 & 475 to 2259 & 0.29 to 1.36 & 0 to 5 \\
\hline
\end{tabular}




\section{Evaluation of Palliative Application Methods}

A major component of ERDC's tasking by the Marine Corps Systems Command was to evaluate equipment alternatives for applying dust palliatives in an expeditionary environment. General criteria used to evaluate palliative distribution systems included:

a. Uniformity of product distribution.

b. Simplicity of the distribution process.

c. Effectiveness of a variety of palliative types.

d. Manpower requirements for product application.

e. Logistical footprint of equipment.

(1) Goal: CH-53 Deployable.

(2) Threshold: C-130 Deployable.

f. Cost of equipment.

Selected commercially available equipment was borrowed, leased, or purchased by the ERDC and evaluated at the Waterways Experiment Station (WES) in Vicksburg, MS, prior to the Yuma experiment. Different devices were evaluated for the application of both dry and liquid palliatives. However, the dry palliative distribution equipment was not deemed suitable for immediate demonstration during the Yuma experiment due to the necessity of modifying the equipment for USMC use prior to fielding. Each system was evaluated using the criteria listed previously. Specific recommendations for acquisition are provided at the end of this report. This chapter briefly describes the commercial application equipment evaluated and their performance during field evaluations conducted at the WES and the Yuma test site. 


\section{Test Site Description}

The test site for the field experiment consisted of open desert immediately north of the Auxiliary 2 paved landing zone on MCAS Yuma. The site was cleared of native vegetation prior to product application using a motor grader and bucket loader (TRAM). Once the surface crust was disturbed, the graded sand was very loose to a depth of 10 to $12 \mathrm{in}$. The remolded shear strength of the loose sand was measured using a Geonor vane shear device and averaged $22 \mathrm{kPa}$ or $3.2 \mathrm{psi}$, which correlates to a $0.7 \mathrm{CBR}$ or a cone index of 30 . The test area was divided into two lanes. Lane 1 was approximately 130 - $\mathrm{ft}$-wide by 1,635 -ft-long immediately north of the paved Aux 2 Landing Zone. An open desert buffer of $75 \mathrm{ft}$ minimum width was left between lanes 1 and 2 . Lane 2 was approximately 130 -ft-wide by 1,330 -ft-long. Sixteen 115 - by 130 -ft helipads were outlined in the two lanes with each helipad separated by a $75-$ by $130-\mathrm{ft}$ graded sand untreated buffer zone. Two additional helipads were outlined immediately east of Lane 2 including one treated helipad (Helipad 17) and one untreated control helipad (Helipad 18). A general site layout is shown in Figure 8. Photo 9 shows the graded site prior to product application. The sites were prepared for product application on 17 January 2004.

\section{Equipment Evaluation}

Several types of application systems were used to apply dust control palliatives on seventeen 115 - by 130 -ft helipads as shown in Figure 8 from 18 to 20 January 2004. The application systems included a heavy-duty T-90 Finn Hydroseeder (Photo 10), a light-duty L-90 Easy Lawn Hydroseeder (Photo 11), a HMMWV application system developed by the Marine Corps (Photo 12), a 2400-gal CRC tanker truck with a fire hose type distributor (Photo 13), a commercial water truck with a fire hose distributor (Photo 14), and an 1800-gal agricultural trailer-mounted tank (Photo 15). A trailer-mounted asphalt emulsion system equipped with a five-nozzle distribution bar was brought to the site to apply dust palliatives; however, due to maneuverability issues in the soft sands, the system was not used during this exercise. Table 2 lists the helipads constructed and identifies the equipment used, required manpower and overall application time.

The original plan was to tow the hydroseeders using a Marine Corps HMMWV vehicle. This vehicle proved to be inadequate due to the soft sands at the field site (Photo 16). Due to hitch height limitations on the hydroseeders, the HMMWV had to be used as the tow vehicle; therefore, an unloaded MTVR was used to tow both the HMMWV and each of the hydroseeders during the entire exercise (Photo 17). Both hydroseeders have three methods for applying dust control palliatives: a hose distributor, a tower gun, and a distributor bar (not on Finn model used). The distributor bar was not provided on the Finn model used and the bar on the Easy Lawn system was not used due to maneuverability issues in the soft sands. 


\section{T-90 Finn Hydroseeder}

The T-90 Finn Hydroseeder was used on eight of the helipad test areas. Two application methods were used to apply the palliatives; the hand-spray hose system was used on three sites (Photo 18), the tower gun system on three sites (Photo 19), and a combination of the hose and tower gun systems on two sites. Pressure at the distribution end of the spray hose and tower gun was controlled by the motor rpm; volume was controlled with an in-line ball valve located at or near the distribution end.

\section{Table 2}

Dust Palliative Application Equipment and Time

\begin{tabular}{|l|l|l|l|l||}
\hline \hline & $\begin{array}{l}\text { Helipad } \\
\text { Number } \\
\text { (Fig. 6) }\end{array}$ & Equipment & Manpower & $\begin{array}{l}\text { Time, } \\
\text { min }\end{array}$ \\
\hline \hline PolyPlus 100 & 1 & DAV \& 4,000-gal Water Truck & 5 & 118 \\
\hline PolyPlus & 2 & DAV \& 4,000-gal Water Truck & 5 & 168 \\
\hline Tri-PAM & 3 & DAV \& 4,000-gal Water Truck & 5 & 191 \\
\hline Envirotac A & 4 & 1800-gal Gravity Fed Trailer w/Tractor & 3 & 23 \\
\hline Soiltac A & 5 & 2400-gal CRC Tanker with 200-ft Hose & 4 & 93 \\
\hline Soiltac B & 6 & 2400-gal CRC Tanker with 200-ft Hose & 4 & 44 \\
\hline Envirotac B & 7 & 1800-gal Gravity Fed Trailer w/Tractor & 3 & 18 \\
\hline ECO 110 & 8 & 2000-gal Water Truck with 200-ft Hose & 4 & 40 \\
\hline LDC & 9 & Finn Hydroseeder - Tower Gun System Only & 2 & 7 \\
\hline NRLA & 10 & Finn Hydroseeder - 200-ft Hose System Only & 4 & 65 \\
\hline NRL B & 11 & Finn Hydroseeder - Tower Gun \& Hose & 4 & 41 \\
\hline Road Oyl & 12 & Finn Hydroseeder - Tower Gun System Only & 2 & 14 \\
\hline EnviroKleen B & 13 & Easy Lawn Hydroseeder - Tower Gun \& Hose & 4 & 51 \\
\hline Dustac A & 14 & Finn Hydroseeder - 200-ft Hose System Only & 4 & 17 \\
\hline EnviroKleen A & 15 & Finn Hydroseeder - Tower Gun \& Hose & 4 & 24 \\
\hline Soil-Sement & 16 & Finn Hydroseeder - Tower Gun System Only & 2 & 60 \\
\hline Dustac B & 17 & Finn Hydroseeder - Tower Gun System Only & 2 & 5.5 \\
\hline Untreated & 18 & Not Applicable & 0 & 0 \\
\hline \hline & & & 2 to 5ange of Values: & 191 \\
\hline \hline
\end{tabular}

The spray hose system required a minimum of four personnel to efficiently operate, three maneuvering the hose around the pad and one operating the pump at the hydroseeder. Generally, the wide fan nozzle ( $30 \mathrm{gpm}$ at $60 \mathrm{psi}$ ) and $200-\mathrm{ft}$ hose was used for this application. Periodic comparisons between the surface area covered and the hydroseeder tank fluid level ensured adequate coverage to the pad. The overall rating of the spray hose system was good. The length of hose was adequate, the application coverage was good, the pressure on the distribution end of the hose remained constant until the tank was emptied, and the nozzles were easily changeable. 
The tower gun system required a minimum of two personnel to operate, one to operate the gun and one to monitor the fluid level in the tank. Generally, two nozzles were used to ensure coverage, the high-volume long distance nozzle and the narrow fan nozzle. Again, comparing the surface area covered with the hydroseeder tank fluid level ensured adequate coverage to the helipad. The overall rating of the tower gun system was good to fair. The application coverage was somewhat dependent on wind direction and speed. In two instances, the application was applied to the entire test helipad from one location, a distance of $130 \mathrm{ft}$. On the other site, the hydroseeder had to be maneuvered to a second location to ensure good coverage due to adverse wind conditions. The pressure at the distribution end of the gun remained constant until the tank was emptied, and the nozzles were easily changeable.

The diesel engine on the Finn hydroseeder operated flawlessly during the course of this exercise. The engine exhaust was expelled in the horizontal direction just above the trailer frame, which did not create additional dust problems at the hydroseeder. The overall diesel engine and system on the Finn device was rated excellent. The pump system also performed excellent during the course of this exercise; however, it required an operator at the hydroseeder to engage and disengage during operations. The pump system did not have an adequate bypass for the pump to operate when the distribution end valve was closed. The mechanical agitator on the T-90 worked excellent during the course of the exercise. Most of the dust control palliatives were viscous in nature and required extensive agitation to ensure uniform mixture. The agitation system was probably overkill for this operation; however, it worked great when needed. Specifications for the T-90 Finn Hydroseeder used are shown in Table 3.

\begin{tabular}{|c|c|}
\hline \multicolumn{2}{|c|}{$\begin{array}{l}\text { Table } 3 \\
\text { T-90 Finn Hydroseeder Specifications }\end{array}$} \\
\hline Tank & $\begin{array}{l}\text { Metal with } 940 \text {-gal capacity } \\
\text { Mechanical agitator variable-speed reversible hydraulic motor } \\
\text { Liquid recirculation }\end{array}$ \\
\hline Engine & Diesel 4 cylinder water cooled, 33.5-hp, 15-gal fuel capacity \\
\hline Pump & $\begin{array}{l}\text { Centrifugal } 4-\text { by } 2 \text {-in., } 170 \mathrm{gpm} \text { at } 100 \mathrm{psi} \\
\text { Solid clearance adjustable, direct drive with center clutch }\end{array}$ \\
\hline Tower Gun & $\begin{array}{l}\text { Spray distance up to } 180 \mathrm{ft} \\
\text { Nozzles-Set of } 4: 2 \text { long distance, } 1 \text { wide fan, } 1 \text { narrow fan }\end{array}$ \\
\hline Spray Hose & $\begin{array}{l}200 \text { feet, } 1-1 / 2 \text { in. rubber } \\
\text { Nozzles-Set of } 3: 1 \text { long distance, } 1 \text { wide fan, } 1 \text { narrow fan }\end{array}$ \\
\hline Trailer & $\begin{array}{l}7,000 \text {-lb tandem axles, rubber torsion suspension, } \\
\text { Electric brakes } \\
12.4 \text { cu ft storage box } \\
\text { Highway tires: } 9.5 \text { - by } 16.5 \text {-in. tubeless, load range E }\end{array}$ \\
\hline Hitch & $\begin{array}{l}\text { Heavy-duty hitch eye or } 2-5 / 16 \text {-in. ball } \\
\text { Adjustable height: } 12 \text { to } 23 \text { in.; Weight: } 1,900 \mathrm{lb}\end{array}$ \\
\hline Empty Weight & $5,420 \mathrm{lb}$ \\
\hline Working Weight & $14,670 \mathrm{lb}$ \\
\hline $\begin{array}{l}\text { Overall } \\
\text { Dimensions: }\end{array}$ & Length $-16 \mathrm{ft} 2$ in.; Width $-7 \mathrm{ft} 1 \mathrm{in}$.; Height $-9 \mathrm{ft}$ (top of tower gun) \\
\hline Unit Cost & $\$ 34,395$ \\
\hline Point of Contact & $\begin{array}{l}\text { John Imm, Sales Manager } \\
\text { Finn Corporation, } 9281 \text { LeSaint Drive, Fairfield, Ohio } 45014 \\
1-800-543-7166 \text { (office) or } 513-290-3057 \text { (cell) }\end{array}$ \\
\hline
\end{tabular}




\section{L-90 Easy Lawn Hydroseeder}

The light-duty Easy Lawn hydroseeder was only used on one of the helipad test areas. Both, the spray hose and tower gun systems were used to apply the palliative (Photo 20). Pressure at the distribution end of the spray hose and tower gun was controlled by the motor rpm and volume was controlled with an in-line ball valve located at or near the distribution end.

The spray hose system required a minimum of four personnel to operate, three maneuvering the hose around the pad and one monitoring the tank fluid level at the hydroseeder. The wide fan nozzle ( $10 \mathrm{gpm}$ at $40 \mathrm{psi})$ was used to apply the palliative for this application. Comparing the surface area covered with the hydroseeder tank fluid level ensured adequate coverage to the helipad. The overall rating of the spray hose system was fair. The $100-\mathrm{ft}$ length of hose was not adequate to cover the test site from one location; therefore, the hydroseeder was maneuvered to a second location. The application coverage was good until the tank reached a low fluid level (approximately $75 \mathrm{gal}$ ) where the agitation incorporated air into the system, thus reducing pressure. The reduced pressure significantly impaired coverage.

The tower gun system required a minimum of two personnel to operate, one to operate the gun and one to monitor the fluid level in the tank. The tower gun was used in conjunction with the spray hose system on this site. Generally, two nozzles were used to ensure coverage, the high volume long distance nozzle and the narrow fan nozzle. The overall rating of the tower gun system was fair. The application coverage was dependent on wind direction and speed. The system seemed to lack pressure to reach areas beyond $75 \mathrm{ft}$. The pressure at the distribution end of the gun was very unstable when the fluid level in the tank was low (approximately $75 \mathrm{gal}$ ), significantly impairing coverage.

The gasoline engine on the Easy Lawn hydroseeder operated excellent during the course of this exercise, but the engine exhaust was expelled in the vertical direction just below the motor. This created some dust around the engine area of the hydroseeder. The pump system operated fair during the course of this exercise. The pump system on this hydroseeder was always engaged and did not require an operator at the hydroseeder during operation. The pump system, however, was not able to completely drain the Hydroseeder tank due to the agitation incorporating air into the system. This system did not have a ball valve to close off the return fluid agitator. Specifications for the L-90 Easy Lawn Hydroseeder used are shown in Table 4.

\section{Marine Corps HMMWV Dust Abatement Vehicle (DAV)}

The palliative application system developed by the Marine Wing Support Group (MWSG) 27 was used to apply the MCWL's Tri-PAM and PolyPlus products to three of the helipads. The application system consisted of a HMMWV with a 6-ft-wide mechanical drop spreader mounted on the front of the vehicle. A 500 -gal plastic water tank was mounted in the bed of the vehicle with a pressurized pump and two 35 - to 50 -gpm spray nozzles powered by a Honda generator. 


\begin{tabular}{|c|c|}
\hline \multicolumn{2}{|c|}{$\begin{array}{l}\text { Table } 4 \\
\text { L-90 Easy Lawn Hydroseeder Specifications }\end{array}$} \\
\hline Tank & $\begin{array}{l}\text { Plastic, 900-gal capacity } \\
\text { Hydraulic Agitator/Recirculation Pipe }\end{array}$ \\
\hline Engine & $\begin{array}{l}\text { OHV V-Twin Electric Start, } 25 \text {-hp Robin Subaru } \\
\text { Fuel capacity - } 16 \text { gal }\end{array}$ \\
\hline Pump & $\begin{array}{l}\text { Centrifugal } 4 \text { - by } 3 \text {-in., } 620 \mathrm{gpm} \text { max or } 85 \mathrm{psi} \mathrm{max} \text {, } \\
75 \text { psi operating pressure }\end{array}$ \\
\hline Tower Gun & $\begin{array}{l}\text { Spray distance up to } 145 \mathrm{ft} \\
\text { Nozzles-Set of } 4: 2 \text { long distance, } 1 \text { wide fan, } 1 \text { narrow fan }\end{array}$ \\
\hline Spray Hose & $\begin{array}{l}100 \mathrm{ft} \text { Poly: } 1.5 \text {-in.-diam } \\
\text { Nozzles: variable up to } 50 \mathrm{gpm} \text { at } 40 \mathrm{psi}\end{array}$ \\
\hline Trailer & $\begin{array}{l}\text { 6,000-lb tandem axles, spring suspension } \\
7 \text {-cu ft storage box } \\
\text { Tires }-16.5 \text {-in. tubeless with highway tread, load range } E\end{array}$ \\
\hline Hitch & $\begin{array}{l}\text { Heavy-duty hitch eye or } 2-5 / 16 \text {-in. ball } \\
\text { Adjustable height:12 to } 24 \text { in.; Hitch weight: } 900 \mathrm{lb}\end{array}$ \\
\hline Empty Weight & $4,700 \mathrm{lb}$ \\
\hline Working Weight & $12,000 \mathrm{lb}$ \\
\hline Overall Dimensions & $\begin{array}{l}\text { Length: } 15 \mathrm{ft} \text { and } 9 \text { in. } \\
\text { Width- } 7 \mathrm{ft} \text { and } 11.5 \text { in. } \\
\text { Height: } 8 \mathrm{ft} \text { and } 3 \text { in. (top of tower gun) }\end{array}$ \\
\hline Unit Cost & $\$ 18,500$ \\
\hline Point of Contact & $\begin{array}{l}\text { Bob Lisle, } \\
\text { Easy Lawn, Inc., } 9599 \text { Nanticoke Business Park Drive, Greenwood, DE } \\
19950 \\
1-800-638-1769 \text { or } 302-349-0800\end{array}$ \\
\hline
\end{tabular}

A 6-ft-wide chain link fence drag mounted under the belly of the vehicle was used to scarify the helipad surface.

The dust palliative applied by MCWL personnel is commonly referred to as Tri-PAM. The typical application method for the product is described below:

a. The entire site was leveled using the HMMWV's belly-mounted fence and hand rakes by 3 personnel. This process took approximately $15 \mathrm{~min}$ to complete (Photo 21).

b. Then, the Tri-PAM dry powder was applied with the 6-ft-wide mechanical drop spreader by completely traversing the site with multiple passes of the HMMWV (Photo 22).

c. Following the dry palliative application, the HMMWV's belly-mounted fence drag, was used to incorporate the material into the surface approximately 1 in. Hand rakes were also used to ensure material was incorporated into surface by 2 to 3 personnel (Photo 23).

d. Once the dry material was scarified into the surface, approximately 1,650 to 2,000 gal of water combined with emulsified PAM was applied to the surface of the test area (Photo 24). A hand sprayer using a 1-in. hose was used to overspray areas that appeared to have inadequate emulsion coverage. Thus, the DAV system will require an additional water storage asset such as a water truck or an MTVR with at least three sixcons of water. 
The MWSG 27 DAV application system required a minimum of five personnel to operate including: a HMMWV operator, marshaller/controller, and support for filling/raking. Several problems were noted during operation:

a. The dry palliative was too fine for the mechanical drop spreader, which resulted in uncontrolled leakage of the powder. The drop spreader storage capacity was limited to approximately $40 \mathrm{lb}$ of material requiring numerous refillings and a Marine to hand-level the material for better distribution after every pass of the device.

$b$. The belly-mounted fence drag was provided by the ERDC but was deemed only marginally effective for leveling the loose sand and scarifying the dry palliative into the helipad surface.

c. Although the HMMWV was equipped with a 500 -gal water tank, it could only be filled with approximately 250 gal of water or PAM emulsion due to axle load limitations on the HMMWV. This required as many as eight refillings of the tank (Photo 25).

d. The two nozzles used with the DAV to distribute the liquid emulsion were 35 -gpm nozzles and were not deemed sufficient to effectively apply the emulsion. A distribution bar would be more effective in distributing the liquid emulsion.

\section{Specifications on the MTVR}

Due to the very poor site mobility conditions resulting from 10 to $12 \mathrm{in}$. of loose sand, a MTVR was used to tow the HMMWV and hydroseeder equipment around the site. The lack of flotation tires on the hydroseeders leased for the exercise only added to the mobility problems. Thus, a conclusion from the application phase of the experiment was that some sites in theater might have extremely limited mobility similar to that experienced at Yuma, although expeditionary airfield (EAF) personnel indicated that such sites would routinely be avoided during FARP site selection. EAF personnel observing the experiment indicated that MTVRs would be available during the establishment of new FARP sites. Thus, it was deemed appropriate to evaluate the possibility of mounting a palliative distribution system on the back of an MTVR for added mobility. Relevant dimensions were taken from the MTVR during the exercise to assist in unit specifications for future work. Dimensions provided below are approximate:

Flat Bed Dimensions $=225$-in.-long and 91-in.-wide

Eleven Tie Down Anchors are located on each side of the bed. The locations as measured from the rear of the bed are $2.5,33,72,83,112.5,123.25,134.5$, 145.5, 179, 194, and 215 in. Eight Cam lock tie downs are also located on each side of the bed and are located at 2.5, 72, 83, 112.5, 123.25, 134.5, 145.5 and 215 in. from the rear of the bed. 
Hitch height $=37.5$ in. (measured to center of hitch)

Rear drop bumper height $=29$ in.

Pay load $=7.5$ tons cross country

Tow load $=11$ tons

\section{Specifications on the HMMWV}

Relevant dimension were also taken from the HMMWV, A2 Model, during the exercise to assist in unit specifications for future work. Dimensions provided below are approximate:

Hitch height $=28.5$ in.

Pay load $=4,575 \mathrm{lb}$ 


\section{Field Evaluation of Dust Palliatives}

As shown in Figure 8, seventeen helipads were treated with dust palliatives including three experimental helipads treated with MCWL's PAM products, two helipads treated with the NRL's experimental products, and 12 helipads treated with one of eight commercial-off-the-shelf (COTS) products. Table 1 provides a description of each helipad in terms of the product name, amount of product used, quantity of water used, total amount of diluted product used, and the initial number of CH-46 aircraft operations conducted on 21 January 2004 after 3 days of curing. As shown, only seven helipads were tested on 21 January 2004 to allow equivalent curing times on the remaining helipads prior to traffic (Photos 26 through 29). Additional traffic was scheduled for these and the remaining helipads from 22 through 24 January including UH-1, AH-1, CH-46, and $\mathrm{CH}-53$ aircraft. However, the additional traffic was postponed due to receiving up to $0.5 \mathrm{in}$. of rainfall on the evenings of 21 and 22 January 2004. Thus, the data collection was incomplete and interim recommendations for initial procurement of dust palliatives were based upon the limited tests conducted, logistical requirements for products, and procurement availability. Additional flight tests were conducted with $\mathrm{CH}-46$ and $\mathrm{CH}-53$ aircraft in February 2004 and will be discussed in detail in this chapter.

\section{Initial Aircraft Testing}

As noted, Table 1 lists the seven helipads that received traffic on 21 January 2004 and the initial number of $\mathrm{CH}-46$ aircraft operations conducted. The six treated helipads tested were allowed to cure for approximately three days from the time of application, primarily due to aircraft scheduling. Since the initial flight tests were suspended, only three products were assessed including two variations of the NRL experimental product (Helipads 10 and 11), two application rates of Soiltac $\mathbb{R}$ (Helipads 5 and 6), and two application rates of Envirotac II ${ }^{\circledR}$ (Helipads 4 and 7). Each landing sequence consisted of a vertical approach and landing, followed by a vertical climb, a 50 - $\mathrm{ft} \mathrm{hover,} \mathrm{another}$ landing, then a vertical climb and departure. Each sequence was repeated three times for data collection. In addition, an initial landing and departure were conducted on some helipads to "dust off" the helipad due to accumulated dust from operations conducted on adjacent helipads prior to data collection. Table 1 
lists the number of initial aircraft operations conducted on selected helipads on 21 January 2004.

Based upon the limited $\mathrm{CH}-46$ landings initially applied to the helipads on 21 January 2004 and subsequent pilot feedback, the NRL products (Helipads 10 and 11) performed excellent and were successful in reducing the amount of airborne dust generated during landings and providing pilots with excellent ground visibility (Photo 26$)$. The heavy application rate of Soiltac $\mathbb{R}($ Helipad 5$)$ performed nearly as well as Helipads 10 and 11 and provided excellent dust abate-

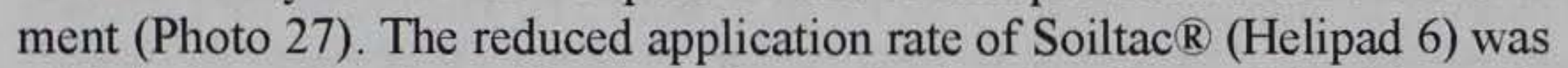
slightly less effective with minor dust and minor break-up of the thin surface crust (Photo 28 ). The two Envirotac II ${ }^{\circledR}$ helipads, 4 and 7, performed similarly and were moderately effective in reducing the amount of airborne dust. The pilots indicated that all of the treated helipads significantly reduced the dust generated during landings compared to the untreated control helipad (Helipad 18) shown in Photo 29.

\section{Primary Flight Tests}

On 21 and 22 January 2004, rainfall events produced approximately 0.5 in. of precipitation on the site. The remaining flight tests were postponed and rescheduled for 18 and 19 February to allow the site to dry. $\mathrm{CH}-46$ aircraft were rescheduled for operations on 18 February 2004, and CH-53 aircraft were rescheduled for operations on 19 February 2004. These test dates are approximately 30 days after initial product application. The following paragraphs describe the tests conducted.

\section{Helipad characterization}

Each helipad was subjected to a variety of tests in order to define the characteristics of each helipad for performance comparison. Helipad characterization consisted of visual observations, strength testing, and nuclear moisture and density measurements. The visual observations consisted of crust thickness, moisture depth, and surface texture. The strength testing included the use of a Torvane shear device for measuring near surface strength (depths less than 3 in.), a Geonor vane shear device for measuring shear strength from 3 to 6 in., and dynamic cone penetrometer (DCP) tests for measuring soil strength at depths up to 36 in. A Troxler ${ }^{\circledR} 3430$ nuclear gage was used to measure the moisture content and density of each helipad. The device was used in the 6-in. direct transmission mode.

Table 5 presents the results of the pre-flight visual observations of the palliatives. These data were collected on 17 February prior to the primary flight tests. Although the site was allowed to dry for several weeks, moisture was still present in the untreated zones at a depth of 1.75 to 2.0 in. (Photo 30). For the treated helipads, moisture was visually identified at depths ranging from 1.5 to $2.3 \mathrm{in}$. below the surface. Thus, there was no significant difference in the depth to moisture between the untreated and treated helipads. The crust thickness, if any, was also 
measured for each helipad. As shown in Table 5, a light crust of 0.25 to 0.5 in. existed for the untreated areas due to the natural saturation and drying process. This light crust was very fragile and disintegrated under the lightest physical touch. The data indicate that Helipads 10 (NRL A), 11 (NRL B), 14 (Dustac $\left.{ }^{\circledR}\right) A$ ), and 17 (Dustac $(B)$ ) had crusts ranging from 0.31 to 0.75 in.; however, these crusts were almost as fragile as the untreated areas indicating that the dust palliatives had been significantly leached by the rainfall. Helipads 1 (PolyPlus 100ß), 2 (PolyPlus ${ }^{\circledR}$ ), and 3 (Tri-PAM) produced moderately brittle crusts ranging in thickness from 0.5 to 1.0 in. (Photo 31 ). The crusts for Helipads

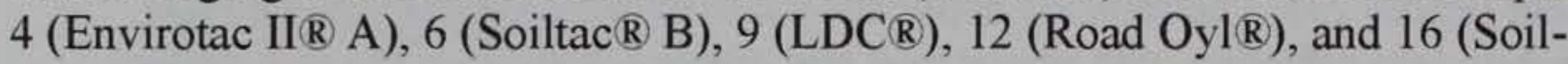
Sement $\mathbb{R}$ ) ranged from 0.31 to 0.69 in., but these crusts were somewhat hard and brittle (Photo 32). Helipads 13 (EnviroKleen ${ }^{\circledR}$ B) and 15 (EnviroKleen ${ }^{\circledR}$ A) did not have brittle crusts as the synthetic oil serves to lubricate and agglomerate

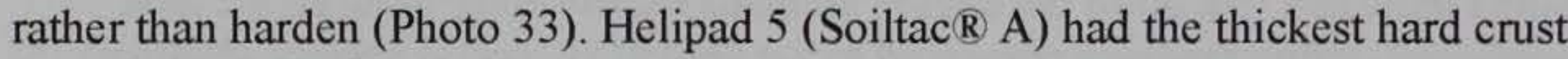
(1.44 in.) of all of the helipads as shown in Photo 34.

\begin{tabular}{|c|c|c|c|c|c|c|c|}
\hline \multicolumn{8}{|c|}{$\begin{array}{l}\text { Table } 5 \\
\text { Pre-Test Visual Helipad Soil Surface Data }\end{array}$} \\
\hline \multirow{2}{*}{\begin{tabular}{|l|} 
Helipad \\
Buffer $1-2$
\end{tabular}} & \multicolumn{2}{|c|}{$\begin{array}{l}\text { Depth to } \\
\text { Moisture, in. }\end{array}$} & \multirow{2}{*}{$\begin{array}{l}\text { Average } \\
\text { Depth, in. } \\
2.0\end{array}$} & \multirow{2}{*}{$\begin{array}{l}\begin{array}{l}\text { Surface } \\
\text { Temp., }\end{array}{ }^{\circ} \mathrm{F} \\
78.0\end{array}$} & \multicolumn{2}{|c|}{$\begin{array}{l}\text { Crust } \\
\text { Thickness, in. }\end{array}$} & \multirow{2}{*}{$\begin{array}{l}\begin{array}{l}\text { Average } \\
\text { Crust, in. }\end{array} \\
-\end{array}$} \\
\hline & 2.0 & 2.0 & & & -- & - & \\
\hline Buffer 4-5 & 2.0 & 2.0 & 2.0 & 78.0 & - & - & - \\
\hline Buffer 8-9 & 1.8 & 1.8 & 1.8 & 78.0 & - & - & - \\
\hline Buffer 10-11 & 1.8 & 1.8 & 1.8 & 78.0 & - & - & - \\
\hline Buffer 13-14 & 1.7 & 1.8 & 1.8 & 78.0 & - & - & - \\
\hline Buffer 15-16 & 1.8 & 1.8 & 1.8 & 78.0 & - & - & $\overline{-}$ \\
\hline 1 & 1.5 & 1.5 & 1.9 & 85.0 & 0.75 & 0.75 & 0.75 \\
\hline 2 & 1.8 & 1.8 & 1.8 & 84.8 & 1.00 & 1.00 & 1.00 \\
\hline 3 & 1.8 & 1.8 & 1.8 & 82.1 & 0.50 & 0.50 & 0.50 \\
\hline 4 & 1.8 & 1.8 & 1.6 & 85.9 & 0.75 & 0.50 & 0.63 \\
\hline 5 & 1.5 & 1.5 & 2.0 & 85.1 & 1.38 & 1.50 & 1.44 \\
\hline 6 & 2.5 & 2.3 & 2.3 & 88.3 & 0.38 & 0.50 & 0.44 \\
\hline 7 & 2.3 & 1.5 & 1.6 & 85.0 & 0.75 & 1.25 & 1.00 \\
\hline 8 & 1.8 & 2.0 & 2.1 & 97.0 & 0.63 & 1.00 & 0.81 \\
\hline 9 & 2.3 & 2.0 & 1.9 & 98.8 & 0.63 & 0.75 & 0.69 \\
\hline 10 & 1.8 & 1.8 & 1.6 & 95.3 & 0.75 & 0.75 & 0.75 \\
\hline 11 & 1.5 & 2.1 & 2.3 & 91.7 & 0.13 & 0.75 & 0.44 \\
\hline 12 & 2.5 & 2.5 & 2.1 & 100.7 & 0.25 & 0.38 & 0.31 \\
\hline \begin{tabular}{|l|}
13 \\
\end{tabular} & 1.8 & 2.0 & 1.8 & 102.5 & 0.50 & 0.50 & 0.50 \\
\hline 14 & 1.5 & 2.0 & 1.9 & 88.7 & 0.75 & 0.75 & 0.75 \\
\hline 15 & 1.8 & 2.0 & 2.1 & 98.6 & 1.50 & 2.75 & 2.13 \\
\hline 16 & 2.3 & 2.0 & 2.0 & 93.4 & 0.38 & 0.25 & 0.31 \\
\hline 17 & 2.0 & 1.5 & 1.6 & 92.3 & 0.75 & 0.63 & 0.69 \\
\hline 18 & 1.8 & 1.5 & 1.5 & 101.3 & 0.50 & 0.50 & 0.50 \\
\hline
\end{tabular}


Various strength tests were conducted to evaluate the effect of the dust palliative on the soil. The strength testing included the use of a Torvane shear device for measuring near surface strength at depths less than 3 in. (Photo 35), a Geonor vane shear device for measuring shear strength from 3 to 6 in. (Photo 36), and dynamic cone penetrometer (DCP) tests (Photo 37) for measuring the strength at depths up to 36 in. The Torvane test results are shown in Table 6, and the Geonor vane shear results are shown in Table 7. The DCP test results are summarized in Table 8 . Since the Torvane shear strength data represent the surface shear strength, its data should be the most meaningful strength data collected due to the shallow depth of palliative application.

\begin{tabular}{|c|c|c|c|c|c|c|c|}
\hline \multicolumn{8}{|c|}{\begin{tabular}{||l} 
Table 6 \\
Torvane Surface Shear Strength Results
\end{tabular}} \\
\hline \multirow{2}{*}{ Helipad } & \multirow{2}{*}{$\begin{array}{l}\text { Vane } \\
\text { Size }\end{array}$} & \multicolumn{5}{|c|}{ Shear Strength, $\mathrm{kPa}$} & \multirow{2}{*}{$\begin{array}{l}\text { Average } \\
\text { Values, kPa }\end{array}$} \\
\hline & & 1 & 2 & 3 & 4 & 5 & \\
\hline Buffer $1-2$ & Large & 0.38 & 0.50 & 0.82 & 0.28 & 0.52 & 0.50 \\
\hline Buffer 45 & Large & 0.32 & 0.40 & 0.40 & 0.26 & 0.38 & 0.35 \\
\hline Buffer 8-9 & Large & 0.22 & 0.42 & 0.36 & 0.36 & 0.48 & 0.37 \\
\hline Buffer 10-11 & Large & 0.44 & 0.48 & 0.50 & 0.54 & 0.42 & 0.48 \\
\hline Buffer 13-14 & Large & 0.44 & 0.44 & 0.32 & 0.46 & 0.44 & 0.42 \\
\hline Buffer $15-16$ & Large & 0.42 & 0.40 & 0.34 & 0.40 & 0.38 & 0.39 \\
\hline 1 & Medium & 7.70 & 8.00 & 5.40 & 7.50 & 7.30 & 7.18 \\
\hline 2 & Medium & 7.60 & 2.00 & 5.40 & 4.60 & 5.70 & 5.06 \\
\hline 3 & Medium & 6.80 & 6.10 & 4.60 & 7.30 & 5.80 & 6.12 \\
\hline 4 & Small & 25.00 & 16.25 & 25.00 & 25.00 & 25.00 & 23.25 \\
\hline 5 & Small & 25.00 & 25.00 & 25.00 & 25.00 & 25.00 & 25.00 \\
\hline 6 & Small & 25.00 & 25.00 & 25.00 & 25.00 & 25.00 & 25.00 \\
\hline 7 & Small & 15.00 & 18.00 & 15.50 & 15.25 & 9.75 & 14.70 \\
\hline 8 & Small & 25.00 & 25.00 & 25.00 & 25.00 & 25.00 & 25.00 \\
\hline 9 & Small & 25.00 & 25.00 & 25.00 & 25.00 & 25.00 & 25.00 \\
\hline $\mid 10$ & Medium & 1.80 & 3.60 & 2.40 & 3.00 & 3.30 & 2.82 \\
\hline $\mid 11$ & Medium & 2.50 & 2.80 & 4.20 & 2.90 & 4.00 & 3.28 \\
\hline 12 & Medium & 4.00 & 2.50 & 3.00 & 3.75 & 3.00 & 3.25 \\
\hline 13 & Large & 0.56 & 0.80 & 0.76 & 0.54 & 0.86 & 0.70 \\
\hline 14 & Large & 0.30 & 0.34 & 0.25 & 0.20 & 0.30 & 0.28 \\
\hline 15 & Large & 0.52 & 0.72 & 0.78 & 0.85 & 0.74 & 0.72 \\
\hline 16 & Medium & 4.75 & 3.40 & 6.50 & 3.50 & 7.00 & 5.03 \\
\hline $\mid 17$ & \begin{tabular}{|l|} 
Large \\
\end{tabular} & 0.38 & 0.55 & 0.50 & 0.55 & 0.58 & 0.51 \\
\hline 18 & Large & 0.32 & 0.30 & 0.25 & 0.40 & 0.40 & 0.33 \\
\hline
\end{tabular}

The Torvane data show that the surface shear strength of the untreated areas ranged from 0.33 to $0.50 \mathrm{kPa}$. The two Dustac $\AA$ helipads (14 and 17) produced similar surface strengths to the untreated areas, and the two EnviroKleen $\mathbb{R}$ helipads (13 and 15) demonstrated only slightly better shear strengths. While the Dustac $\mathbb{R}$ product appeared to have been leached from the surface due to rainfall, the EnviroKleen ${ }^{\circledR}$ product controls dust by lubrication and agglomeration, which does not produce significant strength increases. The two NRL helipads (10 and 11 ) along with the Road Oyl ${ }^{\circledR}$ (Helipad 12) produced only moderate increases in surface strength ranging from 2.82 to $3.28 \mathrm{kPa}$. The three polyacrylamide 
helipads $(1,2$, and 3$)$ along with the Soil-Sement ${ }^{\mathbb{R}}$ helipad (16) produced significant strength increases ranging from 5.03 to $7.18 \mathrm{kPa}$. Finally, the acrylic polymer emulsions (Helipads 4 through 9) produced the highest surface strength increases.

The Geonor vane shear near-surface strength data are presented in Table 7 . The Geonor vane shear data represents the soil strength at a depth of 3 to 6 in. below the surface. For topical applications, this represents the strength immediately beneath the treated zone. As shown in Table 7, the shear strength in this zone is similar for all items and ranges from 11 to $37 \mathrm{kPa}$. Helipads 5 (Soil-

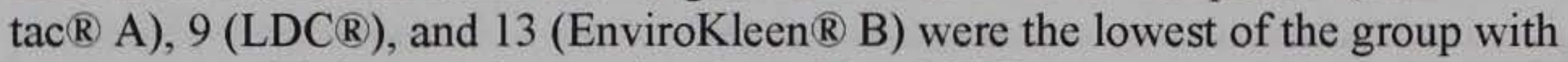
average remolded strengths ranging from 11 to $18 \mathrm{kPa}$.

\begin{tabular}{|c|c|c|c|c|c|c|}
\hline \multicolumn{7}{|c|}{$\begin{array}{l}\text { Table } 7 \\
\text { Geonor Vane Shear Near Surface Strength }\end{array}$} \\
\hline \multirow[b]{2}{*}{ Helipad } & \multirow{2}{*}{$\begin{array}{l}\text { Vane } \\
\text { Size }\end{array}$} & \multirow{2}{*}{$\begin{array}{l}\text { In Situ } \\
\text { Strength, } \\
\text { KPa }\end{array}$} & \multicolumn{3}{|c|}{ Remolded Shear Strength, kPa } & \multirow{2}{*}{$\begin{array}{l}\text { Average } \\
\text { Remolded, } \\
\text { kPa }\end{array}$} \\
\hline & & & Remolded 1 & Remolded 2 & Remolded 3 & \\
\hline Buffer 1-2 & Large & 55 & 27 & 27 & 27 & 27 \\
\hline Buffer 4-5 & Large & 47 & 28 & 28 & 27 & 28 \\
\hline Buffer 8-9 & Large & 35 & 18 & 14 & 16 & 16 \\
\hline Buffer 10-11 & Large & 46 & 22 & 22 & 25 & 23 \\
\hline Buffer $13-14$ & Large & 28 & 16 & 16 & 16 & 16 \\
\hline Buffer 15-16 & Large & 49 & 31 & 26 & 27 & 28 \\
\hline 1 & Medium & 66 & 39 & 38 & 34 & 37 \\
\hline 2 & Medium & 54 & 32 & 28 & 26 & 29 \\
\hline 3 & Medium & 52 & 28 & 27 & 26 & 27 \\
\hline 4 & Medium & 68 & 36 & 32 & 30 & 33 \\
\hline 5 & Medium & 34 & 18 & 18 & 19 & 18 \\
\hline 6 & Medium & 45 & 22 & 24 & 25 & 24 \\
\hline 7 & Medium & 64 & 35 & 36 & 34 & 35 \\
\hline 8 & Medium & 64 & 32 & 30 & 29 & 30 \\
\hline 9 & Medium & 26 & 11 & 12 & 11 & 11 \\
\hline 10 & Medium & 52 & 25 & 28 & 27 & 27 \\
\hline 11 & Medium & 44 & 20 & 22 & 20 & 21 \\
\hline 12 & Medium & 56 & 29 & 28 & 28 & 28 \\
\hline 13 & Medium & 28 & 14 & 15 & 15 & 15 \\
\hline 14 & Medium & 45 & 24 & 22 & 24 & 23 \\
\hline 15 & Medium & 44 & 24 & 26 & 25 & 25 \\
\hline 16 & Medium & 34 & 22 & 20 & 19 & 20 \\
\hline 17 & Large & 40 & 23 & 23 & 23 & 23 \\
\hline 18 & Large & 49 & 26 & 26 & 25 & 26 \\
\hline
\end{tabular}

The DCP data are provided in Table 8 . The DCP data represents the soil strength at different depths. However, in loose sands the device requires approximately 11 in. to provide adequate confinement around the rod in order to measure meaningful results. For the treated helipads with firm crusts, the DCP can 
provide meaningful measurements at shallower depths. The near surface CBR of the loose sand for the treated helipads ranged from 2 to 10 with an average value of 4 . These data represent the layer immediately below the surface crust, if any. The lower sand layer from 12 to 24 in. below the surface ranged in CBR from 4 to 23 . These data show that the test site was very soft, and incapable of withstanding significant aircraft traffic without deformation or improvement.

\begin{tabular}{|c|c|c|c|c|}
\hline $\begin{array}{l}\text { Table } 8 \\
\text { DCP Results }\end{array}$ & & & & \\
\hline Helipad & Depth, in. & CBR, $\%$ & Depth, in. & CBR, $\%$ \\
\hline Buffer 1-2 & - & - & $9-24$ & 9 \\
\hline Buffer 4-5 & - & - & $16-24$ & 10 \\
\hline Buffer 8-9 & - & - & $12-24$ & 23 \\
\hline Buffer $10-11$ & - & - & $12-24$ & 7 \\
\hline Buffer 13-14 & - & -- & $16-24$ & 6 \\
\hline Buffer $15-16$ & - & - & $19-24$ & 8 \\
\hline 1 & $4-16$ & 5 & $16-24$ & 4 \\
\hline 2 & 4-18 & 4 & $18-24$ & 8 \\
\hline 3 & $8-13$ & 10 & $13-24$ & 16 \\
\hline 4 & $8-11$ & 5 & $11-24$ & 7 \\
\hline 5 & $8-18$ & 5 & $18-24$ & 9 \\
\hline 6 & 5-11 & 4 & $11-24$ & 8 \\
\hline 7 & $9-15$ & 3 & $15-24$ & 10 \\
\hline 8 & $5-10$ & 4 & $10-24$ & 15 \\
\hline 9 & 6-14 & 3 & $14-24$ & 20 \\
\hline 10 & $4-8$ & 5 & 8-24 & 10 \\
\hline 11 & $7-13$ & 3 & $13-24$ & 10 \\
\hline 12 & $7-15$ & 6 & $15-24$ & 5 \\
\hline 13 & $7-10$ & 2 & $10-24$ & 4 \\
\hline 14 & 6-13 & 4 & $13-24$ & 8 \\
\hline 15 & $4-11$ & 4 & $11-24$ & 9 \\
\hline 16 & 7-14 & 2 & $14-24$ & 4 \\
\hline 17 & $5-10$ & 2 & $10-24$ & 8 \\
\hline 18 & 7-14 & 2 & 14-24 & 6 \\
\hline
\end{tabular}

A Troxler ${ }^{\circledR} 3430$ nuclear gage was used to measure the moisture content and density of each helipad (Photo 38 ). The device was used in the 6-in. direct transmission mode. Table 9 presents the moisture and density data collected during the flight tests. The average dry density and moisture content of the untreated sections were $108.5 \mathrm{pcf}$ and 1.7 percent, respectively. The average dry density and moisture content of the treated helipads were $108.1 \mathrm{pcf}$ and 1.5 percent, respectively. Thus, there were no significant differences between the density and moisture content of the treated helipads versus untreated areas. Helipads 8 (ECO $110 \mathbb{R})$ and 15 (EnviroKleen $\left.{ }^{\circledR} A\right)$ did display higher moisture contents than the

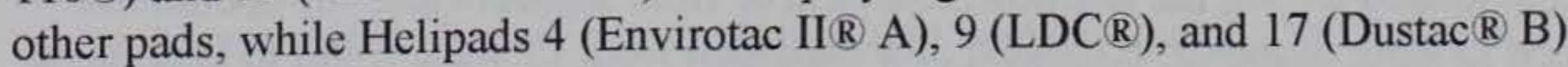




\section{Table 9}

Moisture and Density Data

\begin{tabular}{|c|c|c|c|c|}
\hline Helipad & Wet Density, pcf & Moisture, pcf & Dry Density, pcf & Moisture, $\%$ \\
\hline \multicolumn{5}{|c|}{ Control Zone Buffer Data } \\
\hline Buffer 1-2 & 111.2 & 2.6 & 108.5 & 2.4 \\
\hline Buffer 45 & 110.7 & 1.5 & 109.3 & 1.4 \\
\hline Buffer 8-9 & 112.5 & 1.7 & 110.8 & 1.5 \\
\hline Buffer 10-11 & 109.8 & 1.8 & 108.0 & 1.7 \\
\hline Buffer 13-14 & 107.4 & 1.7 & 105.7 & 1.6 \\
\hline Buffer $15-16$ & 110.8 & 1.2 & 109.5 & 1.1 \\
\hline Average: & 110.3 & 1.9 & 108.5 & 1.7 \\
\hline \multicolumn{5}{|c|}{ Helipad Soil Test Data } \\
\hline 1 & 110.2 & 1.4 & 108.9 & 1.2 \\
\hline 2 & 111.0 & 1.2 & 109.7 & 1.1 \\
\hline 3 & 109.5 & 1.9 & 107.5 & 1.8 \\
\hline 4 & 105.6 & 1.2 & 104.4 & 1.2 \\
\hline 5 & 112.2 & 1.5 & 110.7 & 1.3 \\
\hline 6 & 108.5 & 1.6 & 106.9 & 1.5 \\
\hline 7 & 110.7 & 1.6 & 109.1 & 1.5 \\
\hline 8 & 112.8 & 3.0 & 109.8 & 2.7 \\
\hline 9 & 106.6 & 1.5 & 105.1 & 1.4 \\
\hline 10 & 112.8 & 1.7 & 111.1 & 1.5 \\
\hline 11 & 110.3 & 1.9 & 108.3 & 1.8 \\
\hline 12 & 108.3 & 1.1 & 107.2 & 1.1 \\
\hline 13 & 109.0 & 1.8 & 107.2 & 1.7 \\
\hline 14 & 108.7 & 1.5 & 106.7 & 1.4 \\
\hline 15 & 113.3 & 2.5 & 110.8 & 2.3 \\
\hline 16 & 109.5 & 1.5 & 108.0 & 1.4 \\
\hline 17 & 106.3 & 1.2 & 105.0 & 1.2 \\
\hline 18 & 111.3 & 1.5 & 109.8 & 1.3 \\
\hline Average: & 109.8 & 1.6 & 108.1 & 1.5 \\
\hline
\end{tabular}

demonstrated significantly lower dry densities than the other treated surfaces, but this variability is attributed to site conditions.

\section{$\mathrm{CH}-46$ rotary-wing aircraft testing}

$\mathrm{CH}-46$ rotary-wing flight tests were resumed on 18 February 2004, approximately 30 days after initial product application. Each helipad was subjected to one "dustoff" and three landing sequences. The initial "dustoff" consisted of landing the aircraft on each helipad to blow off any loose debris that had accumulated during the test postponement or from adjacent aircraft operations. Each landing sequence consisted of a transition from forward flight to landing, a 
vertical climb, 50 - $\mathrm{ft}$ hover, and departure. The landing sequence was modified from the initial flight test to reduce the time per cycle in order to complete the testing within the allotted flight window. Stationary dust collectors were used along with visual observations by the pilots and ground personnel to rate the effectiveness of each pad in control the dust.

Two $\mathrm{CH}-46$ pilots from HMM-165 conducted the $\mathrm{CH}-46$ flight tests on 18 February 2004. Photos 39 through 56 depict $\mathrm{CH}-46$ operations on the helipads. The pilots' observations represent the vantage point of the warfighter, the ultimate user of the technology. The $\mathrm{CH}-46$ pilots' observations and ranking of the 18 helipads is provided in Table 10 . Based on the combined $\mathrm{CH}-46$ pilot rankings, the heavy concentration of EnviroKleen ${ }^{\mathbb{R}}$ was clearly noted as the most

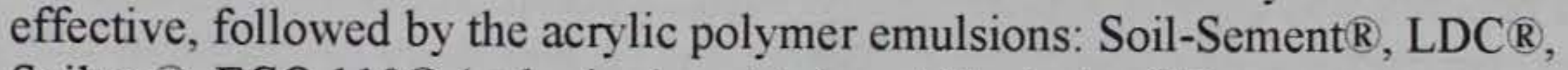

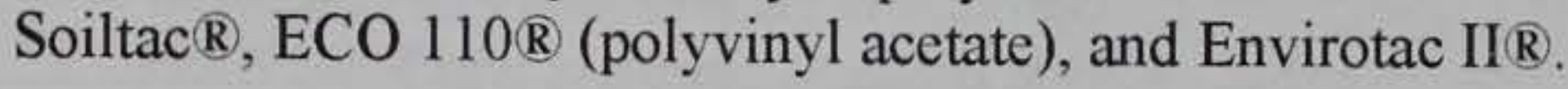

\begin{tabular}{|c|c|c|c|c|}
\hline \multicolumn{5}{|c|}{$\begin{array}{l}\text { Table } 10 \\
\text { CH-46 Pilot Rankings and Observations }\end{array}$} \\
\hline Helipad & Palliative & \begin{tabular}{|l|} 
Pilot \\
Ranking \\
\end{tabular} & \begin{tabular}{|l|} 
Test \\
Order \\
\end{tabular} & Observations \\
\hline 15 & EnviroKleen A & 1 & 9 & Minor dust, almost nothing; Great visibility. \\
\hline 16 & Soil-Sement & 2 & 5 & Better than Helipads 1,4 , and 7. \\
\hline 9 & LDC & 3 & 12 & Minor dust, some flaking. \\
\hline 5 & Soiltac A & 4 & 7 & Little dust; no problem. \\
\hline 8 & ECO 110 & 5 & 8 & Minor dust. \\
\hline 4 & Envirotac A & 6 & 3 & Better than Helipad 1; better each pass. \\
\hline 7 & Envirotac B & 7 & 4 & Similar to helipad 4; improved each landing. \\
\hline 3 & Tri-PAM & 8 & 10 & Dusty. \\
\hline 6 & Soiltac B & 9 & 11 & Dusty; crust beginning to peel. \\
\hline 13 & EnviroKleen B & 10 & 15 & Better than 10 and 14 ; better with each pass. \\
\hline 1 & PolyPlus 100 & 11 & 2 & Slightly better than untreated. \\
\hline 2 & PolyPlus & 12 & 6 & As dusty as Helipad 1 ; Worst of first 5 tested. \\
\hline 12 & Road Oyl & 13 & 18 & Palliative broke up. \\
\hline 10 & NRLA & 14 & 14 & Bad helipad, but better than 14 . \\
\hline 11 & NRL B & 15 & 17 & Same as 10 , progressively worse. \\
\hline 14 & Dustac A & 16 & 13 & Very dusty, worst helipad so far. \\
\hline 17 & Dustac B & 17 & 16 & Worse than Helipad 10. \\
\hline 18 & Untreated & 18 & 1,19 & Worst helipad, but not as bad as Iraq. \\
\hline
\end{tabular}

The ground personnel consisted of representatives of ERDC, MCSC, MCWL, MAWTS-1, and EAF officers from various units. The ground personnel's observations were significantly affected by their location during each test, whether they were downwind or upwind. In addition, the relatively small helipad size, 115- by 130 -ft due to site limitations, impacted the view of ground personnel. While the center of the treated helipads may have generated very little dust, the proximity of the untreated buffers around each pad produced significant dust between the ground personnel and the aircraft. Thus, the pilots' view and the ground personnel's view were not consistent in many instances, and the pilots' 
view should be considered more valid. A consensus ranking of product performance from the ground personnel could not be achieved other than noting which helipads were in the lower half of the evaluation in terms of performance. The ground personnel noted that the following were the worst helipads in terms of reducing airborne dust from worst to marginal: the untreated (18), NRL B (11), Dustac A (14), Dustac B (17), NRL A (10), Road Oyl (12), and the original Tri-PAM (3).

As noted, stationary dust collectors (Photo 57) were located approximately $5 \mathrm{ft}$ from the southeast and southwest sides of the helipad. The dust collectors consisted of a filter placed over a wire mesh screen through which a slight vacuum pressure was drawn using an electric vacuum pump. The dust collectors were manufactured by General Metal Works, Inc., a subsidiary of Andersen Samplers, Inc. The model number of the stationary samplers was BM2200H. Additionally, gravity buckets were placed in the ground at the southwest corner of each helipad (Photo 58). However, the rotor wash may affect the fidelity of the samples collected by gravity methods by blowing collected material out of the buckets upon liftoff. The dust collectors were uncovered after the initial "dustoff" of each helipad, and dust data were collected for the three landing sequences for each helipad. The filters were then removed and weighed to provide a quantitative estimate of the dust generated during landing operations on each helipad. These data were used for direct comparison of helipad performance without the subjectivity of human observations. The dust collector data for the $\mathrm{CH}-46$ landings are presented in Table 11.

\section{$\mathrm{CH}-53$ rotary-wing aircraft testing}

$\mathrm{CH}-53$ rotary-wing flight tests were conducted on 19 February 2004, also approximately 30 days after product application. Each helipad was subjected to one "dustoff" and only two landing sequences. The "dustoff" procedure for initially clearing accumulated surface debris was used again prior to testing each helipad. Each landing sequence consisted of a transition from forward flight to landing, a vertical climb, 50-ft hover, and departure. Photos 59 through 71 show $\mathrm{CH}-53$ operations on selected helipads. Helipad 8, ECO 110 $\mathrm{R}$, was subjected to only one landing sequence due to time limitations of the aircraft on station. The

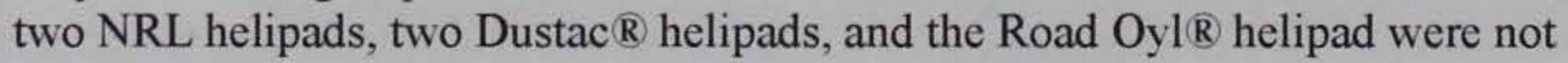
tested due to poor performance under $\mathrm{CH}-46$ traffic and time limitations.

One pilot from HMH-462 conducted the $\mathrm{CH}-53$ flight tests, and the pilot's observations represent the vantage point of the ultimate user of the technology. The CH-53 pilot's observations and rankings of the 18 helipads are provided in Table 12 . Based on the $\mathrm{CH}-53$ pilot's rankings, the EnviroKleen $\mathbb{R}$ was clearly noted as the most effective followed by the acrylic polymer emulsions: Envirotac II ${ }^{\mathbb{R}}$, Soiltac ${ }^{\circledR}, \operatorname{LDC}\left(\mathbb{R}\right.$, and Soil-Sement ${ }^{\circledR}$. The PolyPlus ${ }^{\circledR}$ polyacrylamide helipads were rated similar to the acrylic polymer emulsions.

The ground personnel consisted of representatives of ERDC, MCSC, MCWL, MAWTS-1, and EAF officers from various units. The ground personnel's observations were significantly affected by their location during each test, whether they were downwind or upwind. In addition, the relatively small helipad size, 115- by 


\begin{tabular}{|c|c|c|c|c|}
\hline \multicolumn{5}{|c|}{$\begin{array}{l}\text { Table } 11 \\
\mathrm{CH}-46 \text { Dust Collector Data }\end{array}$} \\
\hline Helipad & Palliative & $\begin{array}{l}\text { Test } \\
\text { Order } \\
\end{array}$ & Dust Collectors, g & Gravity Buckets, g \\
\hline 13 & EnviroKleen B & 15 & 5.8 & 12.2 \\
\hline 8 & ECO 110 & 8 & 6.4 & 8.4 \\
\hline 1 & PolyPlus 100 & 2 & 7.0 & 3.6 \\
\hline 15 & EnviroKleen A & 9 & 7.8 & 11.5 \\
\hline 12 & Road Oyl & 18 & 8.1 & 76.3 \\
\hline 5 & Soiltac A & 7 & 8.2 & 14.1 \\
\hline 9 & LDC & 12 & 8.3 & 4.6 \\
\hline 7 & Envirotac B & 4 & 9.2 & 15.7 \\
\hline 4 & Envirotac A & 3 & 9.4 & 24.6 \\
\hline 16 & Soil-Sement & 5 & 10.0 & 8.1 \\
\hline 10 & NRL A & 14 & 10.9 & 198.5 \\
\hline 6 & Soiltac B & 11 & 12.3 & 52.9 \\
\hline 3 & Tri-PAM & 10 & 14.5 & 43.7 \\
\hline 17 & Dustac B & 16 & 15.6 & 89.2 \\
\hline 18 & Untreated & 1,19 & 16.4 & 358.9 \\
\hline 2 & PolyPlus & 6 & 16.8 & - \\
\hline 11 & NRL B & 17 & 18.5 & 362.3 \\
\hline 14 & Dustac A & 13 & 19.1 & 707.8 \\
\hline
\end{tabular}

$130-\mathrm{ft}$ (due to site limitations), impacted the view of ground personnel, especially with the larger $\mathrm{CH}-53$ aircraft. While the center of the treated helipads may have generated very little dust, the proximity of the untreated buffers around each pad produced significant dust between the ground personnel and the aircraft. Thus, the pilot's view and the ground personnel's view were not consistent in many instances, and the pilot's view should be considered more valid. A consensus ranking of product performance from the ground personnel could not be achieved other than noting which helipads were in the lower half of the evaluation in terms of performance. The ground personnel noted that the following were the worst helipads from in terms of reducing airborne dust: untreated (18), the original TriPAM (3), and the light application of Soiltac $\mathbb{R}$ (6). The light application of Soiltac $\mathbb{R}(6)$ was rated poorly due to isolated break up of the surface crust.

As noted, two stationary dust collectors used for each helipad, each located approximately $5 \mathrm{ft}$ from the southeast and southwest sides of the helipad. The dust collectors were uncovered after the initial "dustoff" of each helipad, and dust data were collected for the two landing sequences for each helipad, except Helipad 8 , which received only one landing sequence. The filters were then removed and weighed to provide a quantitative estimate of the dust generated during landing operations on each helipad. These data are presented in Table 14 and were used for direct comparison of helipad performance; however, due to the small helipad size and large $\mathrm{CH}-53$ aircraft, some variability in data may exist. 


\begin{tabular}{l}
\hline \multicolumn{5}{|l||}{$\begin{array}{l}\text { Table } 12 \\
\text { CH-53 Pilot Rankings and }\end{array}$} \\
\hline \hline
\end{tabular}

\section{Palliative Ratings}

The data presented in the preceding paragraphs presents both subjective and quantitative data used to evaluate the effectiveness of the various palliatives tested. However, some factors influencing the results must be considered. First, the size of the helipads was only 115 - by 130 -ft, which was deemed marginal for the $\mathrm{CH}-46$ and too small for the $\mathrm{CH}-53$ based upon the flight tests conducted. The small helipad size limited the ability of ground personnel to visually evaluate the performance of each helipad. The inclusion of untreated loose sand buffers, 75- by $130-\mathrm{ft}$, between each helipad is not representative of the manner in which a FARP site would be constructed but was necessary to prevent adjacent products from influencing the evaluation of other products. This loose sand buffer zone generated significant amounts of airborne dust due to the small size of the helipads. Post-test interviews with the pilots indicated that most of the helipads were effective in reducing the dust compared to the untreated control helipad (18). Thus, the palliative ratings discussed herein serve to compare the levels of effectiveness between palliatives.

Each helipad was rated using a weighted point system based upon four factors. The resistance to rotor wash was selected as the single most important factor. 


\begin{tabular}{|c|c|c|c|c|}
\hline \multicolumn{5}{|c|}{$\begin{array}{l}\text { Table } 13 \\
\text { CH-53 Dust Collector Data }\end{array}$} \\
\hline Helipad & Palliative & $\begin{array}{l}\text { Test } \\
\text { Order }\end{array}$ & Dust Collectors, $\mathrm{g}$ & Gravity Buckets, $\mathrm{g}$ \\
\hline 15 & EnviroKleen A & 9 & 2.0 & Bucket Dislodged \\
\hline 16 & Soil-Sement & 5 & 2.2 & Bucket Dislodged \\
\hline 5 & Soiltac A & 7 & 2.9 & 3.2 \\
\hline 9 & LDC & 12 & 4.3 & 3.5 \\
\hline 2 & PolyPlus & 6 & 4.4 & 28.9 \\
\hline 13 & EnviroKleen B & 15 & 4.4 & 4.4 \\
\hline 4 & Envirotac A & 3 & 5.6 & 19 \\
\hline 6 & Soiltac B & 11 & 6.2 & 63.1 \\
\hline 8 & ECO $110^{1}$ & 8 & 6.3 & 7.4 \\
\hline 3 & Tri-PAM & 10 & 7.7 & 21.1 \\
\hline 7 & Envirotac B & 4 & 8.1 & 9.5 \\
\hline 1 & PolyPlus 100 & 2 & 8.7 & 12.5 \\
\hline 18 & Untreated & 1,19 & 9.2 & 679.8 \\
\hline 10 & NRLA & 14 & Not Tested & Not Tested \\
\hline 11 & NRL B & 17 & Not Tested & Not Tested \\
\hline 12 & Road Oyl & 18 & Not Tested & Not Tested \\
\hline 14 & Dustac A & 13 & Not Tested & Not Tested \\
\hline 17 & Dustac B & 16 & Not Tested & Not Tested \\
\hline
\end{tabular}

The resistance to rotor wash was rated from 0 to 10 based upon the amount of dust measured using the dust collectors and visual observations from the pilots. The resistance to rotor wash represents the effectiveness of the palliative in mitigating dust and represents 50 percent of the overall rating. The durability of the treated helipad was the second factor considered, and it consisted of a rating from 0 to 10 based upon the ability of the product to withstand environmental changes and occasional traffic. The durability factor represents 20 percent of the final score. The third factor was Foreign Object Debris (FOD) potential, representing 20 percent of the final rating. The FOD potential was rated from 0 to 10 based upon the observed potential of each product in generating FOD for the operating aircraft, as well as adjacent parked aircraft. Finally, the overall surface condition was rated from 0 to 10 based upon the texture of the surface and the impact on military operations such as refueling operations. Table 14 summarizes the ratings of each helipad tested. 


\section{Table14}

\section{Weighted Palliative Ratings ${ }^{1}$}

\begin{tabular}{|c|c|c|c|c|c|c|}
\hline \multirow[b]{2}{*}{ Helipad } & \multirow[b]{2}{*}{ Palliative } & \multicolumn{4}{|c|}{ Rating Factors } & \multirow[b]{2}{*}{$\begin{array}{l}\text { Weighted } \\
\text { Rating } \\
\text { (Up to 100) } \\
\end{array}$} \\
\hline & & $\begin{array}{l}\text { Rotor Wash } \\
\text { Resistance } \\
\text { (Rating } \times 5 \text { ) } \\
\end{array}$ & \begin{tabular}{|l} 
Palliative \\
Durability \\
(Rating X 2) \\
\end{tabular} & $\begin{array}{l}\text { FOD } \\
\text { Potential } \\
\text { (Rating } \times \text { 2) } \\
\end{array}$ & \begin{tabular}{|l} 
Surface \\
Condition \\
(Rating $X 1)$ \\
\end{tabular} & \\
\hline 15 & EnviroKleen A & 50 & 20 & 20 & 10 & 100 \\
\hline 13 & EnviroKleen B & 45 & 15 & 20 & 10 & 90 \\
\hline 4 & Envirotac A & 40 & 20 & 15 & 10 & 85 \\
\hline 5 & Soiltac A & 40 & 20 & 15 & 10 & 85 \\
\hline 7 & Envirotac B & 40 & 20 & 15 & 10 & 85 \\
\hline 9 & LDC & 40 & 20 & 15 & 10 & 85 \\
\hline 1 & PolyPlus 100 & 35 & 20 & 15 & 7 & 77 \\
\hline 2 & PolyPlus & 35 & 20 & 15 & 7 & 77 \\
\hline 16 & Soil-Sement & 40 & 20 & 10 & 7 & 77 \\
\hline 8 & ECO 110 & 30 & 20 & 15 & 10 & 75 \\
\hline 6 & Soiltac B & 30 & 15 & 10 & 7 & 62 \\
\hline 3 & Tri-PAM & 20 & 20 & 10 & 7 & 57 \\
\hline 12 & Road Oyl & 20 & 10 & 5 & 5 & 40 \\
\hline 10 & NRLA & 5 & 5 & 5 & 7 & 22 \\
\hline 11 & NRL B & 5 & 5 & 5 & 7 & 22 \\
\hline 17 & Dustac B & 0 & 0 & 0 & 3 & 3 \\
\hline 14 & Dustac A & 0 & 0 & 0 & 2 & 2 \\
\hline 18 & Untreated & 0 & 0 & 0 & 0 & 0 \\
\hline
\end{tabular}




\section{Conclusions and Recommendations}

The ERDC was tasked by the MCSC to develop two dust control systems, one for expeditionary use on FARPs and one for sustainment use on roads and other large area applications. The project consisted of the evaluation of various dust palliatives and application equipment under controlled laboratory conditions and during field tests. The products of this effort include equipment recommendations, palliative recommendations, and complete application guidance. This report addresses testing performed to evaluate commercial palliatives and palliative distribution systems for expeditionary use in constructing and maintaining FARP sites. Eighteen helipads were constructed at MCAS Yuma using both experimental and commercial palliatives for dust abatement. The application methods were principally topical and expeditionary in nature. Each helipad was subjected to $\mathrm{CH}-46$ rotary-wing aircraft traffic, and selected helipads were subjected to $\mathrm{CH}-53$ traffic. The helipads were evaluated based upon effectiveness in controlling dust, durability, FOD potential, and overall surface condition. Pertinent conclusions from the testing conducted and recommendations for selecting dust abatement methods and materials are provided in the following text.

\section{Conclusions}

The following conclusions were derived from the application and testing of selected dust palliatives from February to March 2004:

a. The commercial water trucks and distributors used to apply the products during the experiment were effective in agitating and distributing a uniform product. However, the cost and poor mobility of the vehicles make them unsuitable for extended military use.

$b$. The agricultural trailer with flotation tires demonstrated very good mobility, but did not include an agitation system for producing a consistent product and required a tow vehicle. In addition, the uniformity of product application was poor.

c. The two hydroseeders used during the experiment provided three methods of distribution, each useful in applying the products. The poor 
mobility of the hydroseeders due to the weight of the trailer-mounted systems reduced their overall effectiveness. However, the devices provided good agitation of the product and excellent uniformity of product distribution over the helipad. These devices provided a rapid means of topically distributing dust palliatives in an expeditionary environment.

d. The dust abatement vehicle (DAV) required the greatest time and manpower for product application of the methods evaluated. The DAV system required calibration of the drop spreader for dry palliative distribution due to the fineness of the dry powder. The system required additional manpower for hand raking the dry palliative into the helipad surface and guiding the vehicle during product distribution. The application of the water-polymer emulsion was time consuming due to the limitations of the spray nozzles used and the requirement to refill the tank. The DAV system was limited in the amount of water it could carry due to axle load limitations and will require additional assets such as an MTVR with water containers to provide the amount of water required for activating polyacrylamides like Tri-PAM.

$e$. The NRL experimental products and Soiltac ${ }^{\circledR}$ were effective in controlling the dust compared to the untreated helipad sections immediately after application with 3 days curing.

f. The following products performed well during testing of the helipads under rotary-wing traffic after 30 days: EnviroKleen $\mathbb{R}$, Envirotac II $\mathbb{R}$,

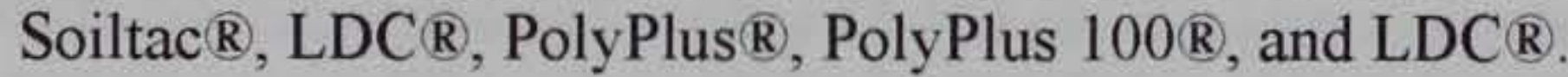

g. ECO 110 $\mathbb{R}$ and Tri-PAM were moderately effective in controlling the dust under the helicopter traffic after 30 days.

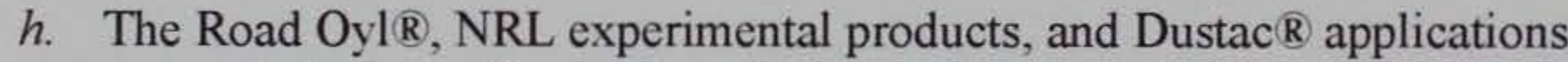
were relatively ineffective in reducing the amount of airborne dust generated during rotary-wing aircraft operations after 30 days. These products were applied at very low application rates, which impacted their effectiveness. The NRL products and Dustac $\AA$ were effectively leached from the helipad during a 0.5 -in. rainfall event and were ineffective in controlling dust in the subsequent test cycle.

$i$. Topical application of dust palliatives is typical of an expeditionary application where construction equipment is nonexistent or limited. Products may perform better using more rigorous construction processes and equipment.

j. Crust forming products tended to provide effective dust abatement under limited traffic, but light applications less than 0.5 gal per square yard broke up during flight operations producing a potential FOD problem.

k. Tri-PAM, PolyPlus $\AA$, and PolyPlus $100 \AA$ provided varying degrees of effectiveness controlled by the intimacy of the mixing process and the 
formation of polymer nodules binding the soil particles together. These products, polyacrylamides, are water absorbing and produced a very tacky surface following a 0.5 -in. rainfall event.

\section{Recommendations}

Based on equipment testing completed by ERDC at the WES and field experience obtained during the exercise, the following recommendations are provided:

a. The palliative distribution system must be maneuverable in soft sand conditions. This requirement means the system must either be a selfpropelled all wheel drive system, a trailer-mounted high flotation towable system that can be towed by a MTVR or TRAM, or a skidmounted system that can be put on a high flotation trailer or on the back of the MTVR.

$b$. The distribution system should have multiple methods for applying dust palliatives. These methods include a spray hose system, a tower gun system, and a distribution bar system. Each system will have applications in the theater, including the distribution bar, which was evaluated at WES by ERDC personnel. The distribution bar will be extremely useful where site mobility permits its use and on larger areas such as roads and airfields.

c. The hydroseeder type equipment is recommended for the distribution system with the minimum requirements indicated in Table 15 . However, the requirements noted in Table 15 should be evaluated for $\mathrm{CH}-53$ and/or C-130 compatibility.

d. Due to the difficulty in securing repair/replacement parts for COTS equipment, it is recommended that two sets of nozzles, two sets of hose clamps and couplings, a hose repair kit, pump parts, and a small engine repair kit are included in the system procured. A toolbox should be included to store the extra parts.

$e$. Both the towed and skid-mounted application systems will require a means of transferring the palliatives from 275-gal totes into the system. Thus, a small pump with $20 \mathrm{ft}$ of 2 -in. hose on each end and extra seals are recommended for inclusion in the system to transfer palliative from shipping containers to the application equipment. Include an in-line quick-connect ball valve on the suction end of the hose.

$f$. The systems evaluated included rudimentary gages of remaining product. An improved system capable of measuring within 25 gal of product should be included in the system selected. The ability to estimate the amount of product remaining is essential to achieving the desired application rate with limited material quantities. 
g. The pulverizer systems commonly included on some hydroseeders are not necessary unless they also serve to agitate the material contained within the tank. As noted, a mechanical system is preferred due to the viscosity of the palliatives evaluated.

$h$. The frame of the trailer or skid-mounted system must be strong enough to support the weight of the loaded system and allow sling loading of the system for rotary-wing transport. The system should include adequate tie-down strong points for sling loading and mounting on an MTVR.

$i$. It is further recommended that a minimum of two 900 -gal towed systems and two 1,200-gal skid-mounted systems be procured with the recommended amounts of product for immediate fielding. Feedback from designated units should be used to refine system parameters.

$j$. The COTS products were commonly shipped in 275-gal totes. It is recommended that the products procured should be packaged in 275-gal totes according to DoD shipping standards as a compromise between capacity and logistical footprint. The possibility of using 200 -gal totes should be pursued to minimize product waste.

$k$. Based upon the limited traffic applied to the helipads and pilot feedback, it is recommended that the USMC procure EnviroKleen $\AA$ and apply the undiluted product "neat" at a minimum application rate of 0.36 gsy and a maximum application rate for sandy soils of 0.5 gsy. Gray water and salt water may be used for dilution.

l. Envirotac II $\mathbb{R}$, Soiltac $\mathbb{R}$, Soil-Sement $\mathbb{R}$, and Liquid Dust Control $\mathbb{R}$ are recommended for use as dust palliatives where a firm surface crust is desired. The concentrated product (approximately 50 percent solids) should be diluted with 2 parts water to 1 part concentrate or a 2:1 dilution ratio. The diluted product should be applied at a minimum application rate of 0.65 gsy.

$m$. It is further recommended that the hydroseeder distribution systems and the dust palliatives recommended be fielded to units for evaluation and feedback. It is recommended that MCSC monitor the units' feedback and lessons learned to develop long-term solutions for dust control on FARP sites. 


\begin{tabular}{|c|c|}
\hline \multicolumn{2}{|c|}{$\begin{array}{l}\text { Table } 15 \\
\text { Minimum Specifications for Dust Palliative Distribution System }\end{array}$} \\
\hline Tank & $\begin{array}{l}\text { Metal (Not Plastic) } \\
1200 \text {-gal capacity for Skid Mounted Systems } \\
1200 \text {-gal capacity for Towed Systems } \\
\text { Mechanical Agitator variable speed reversible } \\
\text { Valve-Control Liquid Re-circulation }\end{array}$ \\
\hline Engine & Diesel, 33.5-hp, Fuel capacity: 15 gal \\
\hline Pump & Centrifugal, $170 \mathrm{gpm}$ at $100 \mathrm{psi}$ \\
\hline Tower Gun & $\begin{array}{l}\text { Minimum Spray Distance of } 150 \mathrm{ft} \\
\text { Nozzles-Set of } 4: 2 \text { long distance, } 1 \text { wide fan, } 1 \text { narrow fan }\end{array}$ \\
\hline Spray Hose & $\begin{array}{l}200 \mathrm{ft}, 1-1 / 2 \text { in. rubber hose for durability } \\
\text { Nozzles-Set of } 4: 2 \text { long distance, } 1 \text { wide fan, } 1 \text { narrow fan }\end{array}$ \\
\hline Distributor Bar & $\begin{array}{l}\text { Minimum of 2-in. line with } 4 \text { sets of } 5 \text { wide-fan nozzles } \\
-1 \text { set of nozzles with a minimum } 10 \mathrm{gpm} \text { at } 40 \mathrm{psi} \\
-1 \text { set of nozzles with a minimum } 20 \mathrm{gpm} \text { at } 40 \mathrm{psi} \\
-1 \text { set of nozzles with a minimum } 30 \mathrm{gpm} \text { at } 40 \mathrm{psi} \\
-1 \text { set of nozzles with a minimum } 40 \mathrm{gpm} \text { at } 40 \mathrm{psi} \\
\text { Adjustable Bar height from } 18 \text { to } 36 \text { in. }\end{array}$ \\
\hline $\begin{array}{l}\text { Trailer } \\
\text { (Towed System) }\end{array}$ & $\begin{array}{l}\text { Tandem axles with sufficient load rating } \\
\text { Electric brakes on both axles } \\
24 \text {-volt compatible light/brake connectors } \\
10 \text { cu ft storage box } \\
\text { Tires - Flotation tires, load range E }\end{array}$ \\
\hline Hitch & $\begin{array}{l}\text { Heavy duty hitch eye or } 2-5 / 16 \text {-in. ball } \\
\text { Adjustable Hitch Height: } 12 \text { to } 40 \text { in. }\end{array}$ \\
\hline Empty Weight & $6,000 \mathrm{lb} \max$ \\
\hline Working Weight & $14,200 \mathrm{lb}$ max \\
\hline Overall Dimensions & $\begin{array}{l}\text { Length }-16 \mathrm{ft} 2 \text { in.; Width }-7 \mathrm{ft} 1 \text { in.; Height }-9 \mathrm{ft} \text { (top of tower gun) } \\
\text { The tower gun and railing must be detachable for achieving a } \\
\text { maximum shipping height of } 78 \text { in. }\end{array}$ \\
\hline
\end{tabular}




\section{References}

Grau, R. H. (1993). "Evaluation of methods for controlling dust," Technical Report GL-93-25, U.S. Army Engineer Waterways Experiment Station, Vicksburg, MS.

Santoni, R. L., Tingle, J. S., and Webster, S. L. (2002). "Stabilization of silty sand with nontraditional additives," Transportation Research Record 1787, pp. 61-72.

Styron, C. R., and Eaves, R. C. (1973). "Investigation of dust control materials," Miscellaneous Paper S-73-70, U.S. Army Engineer Waterways Experiment Station, Vicksburg MS. 


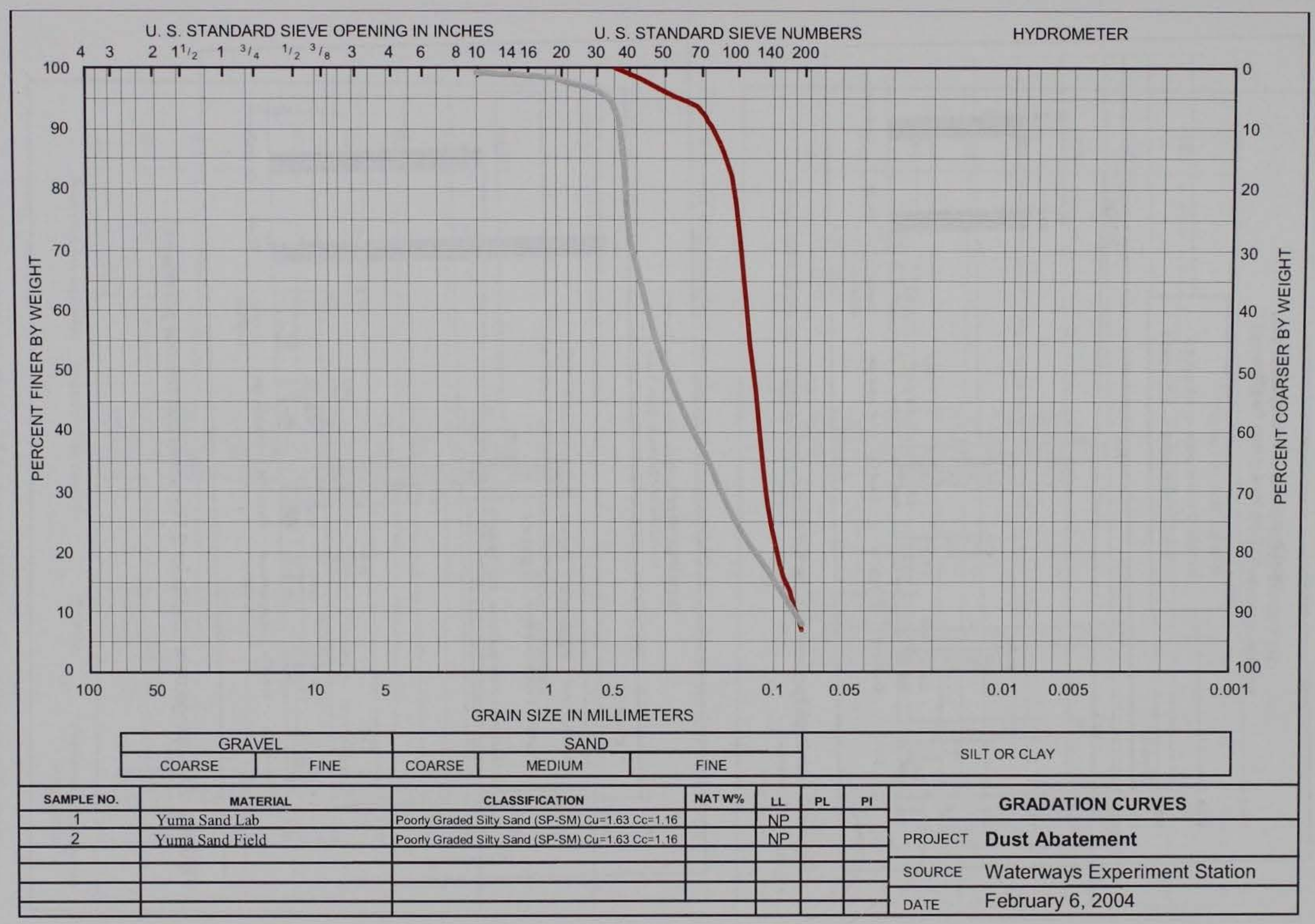

Figure 1. Gradation curve for Yuma sand (SP-SM) 


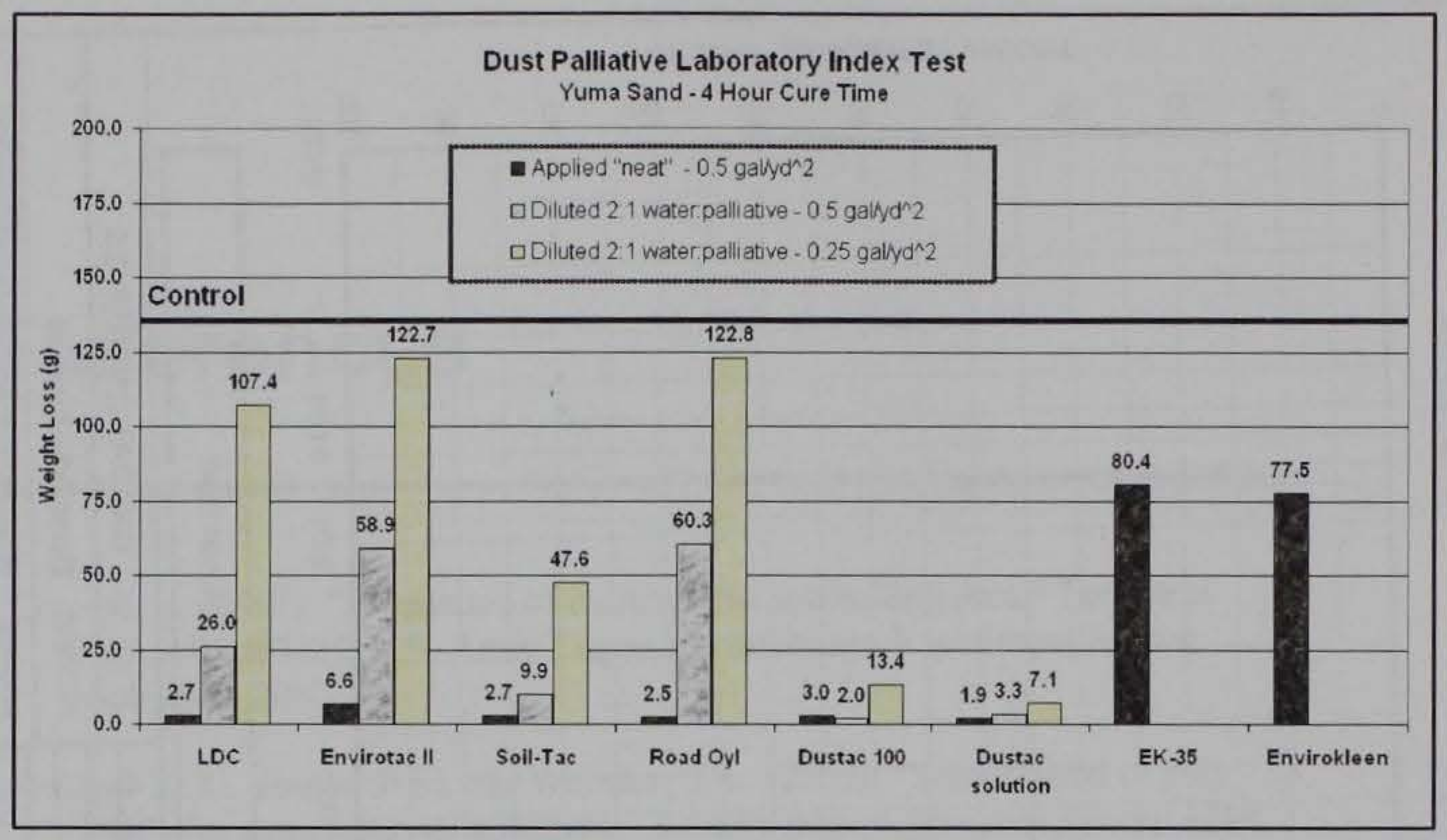

Figure 2. Air impingement results for 4-hr cured commercial palliatives

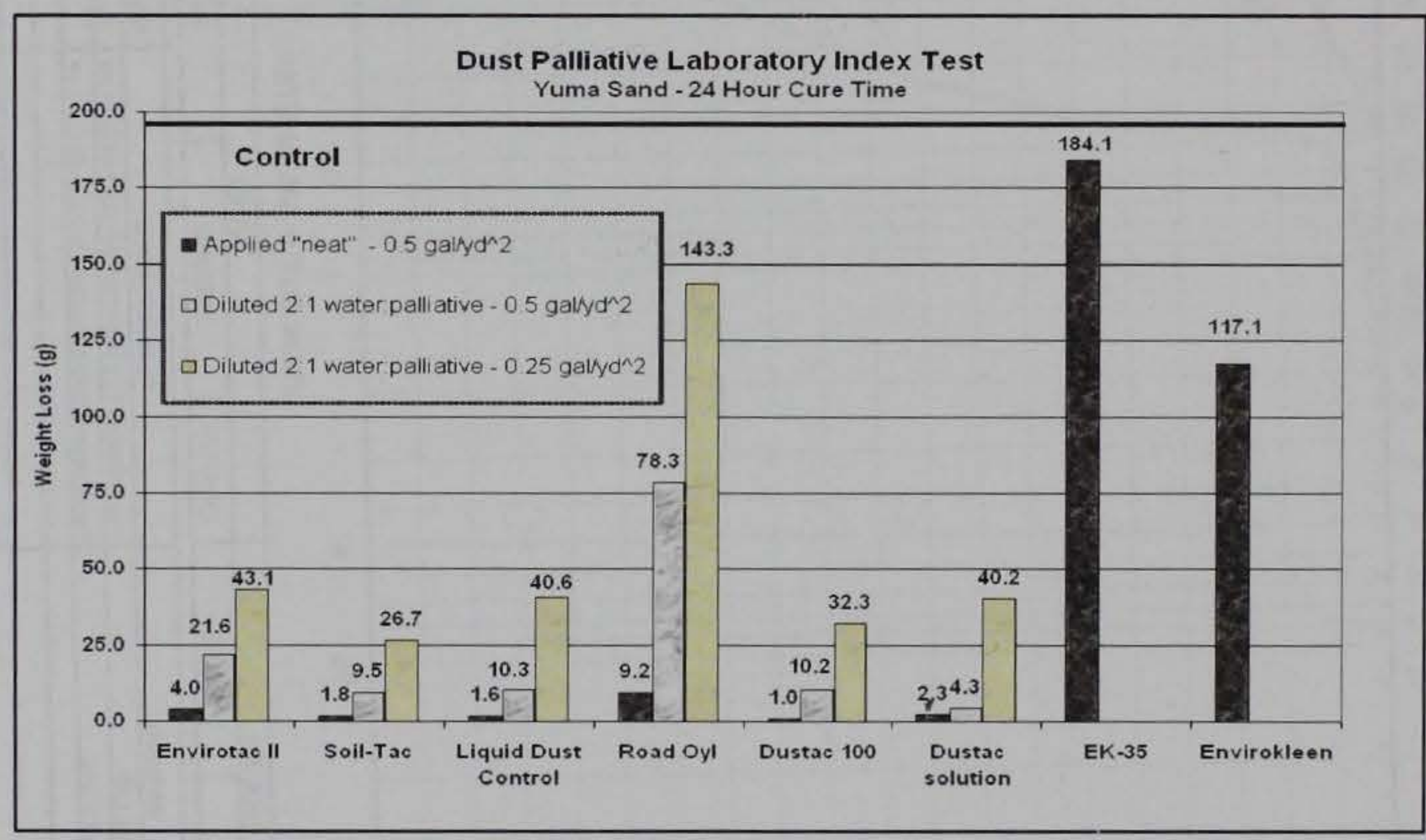

Figure 3. Air impingement results for 24 -hr cured commercial palliatives 


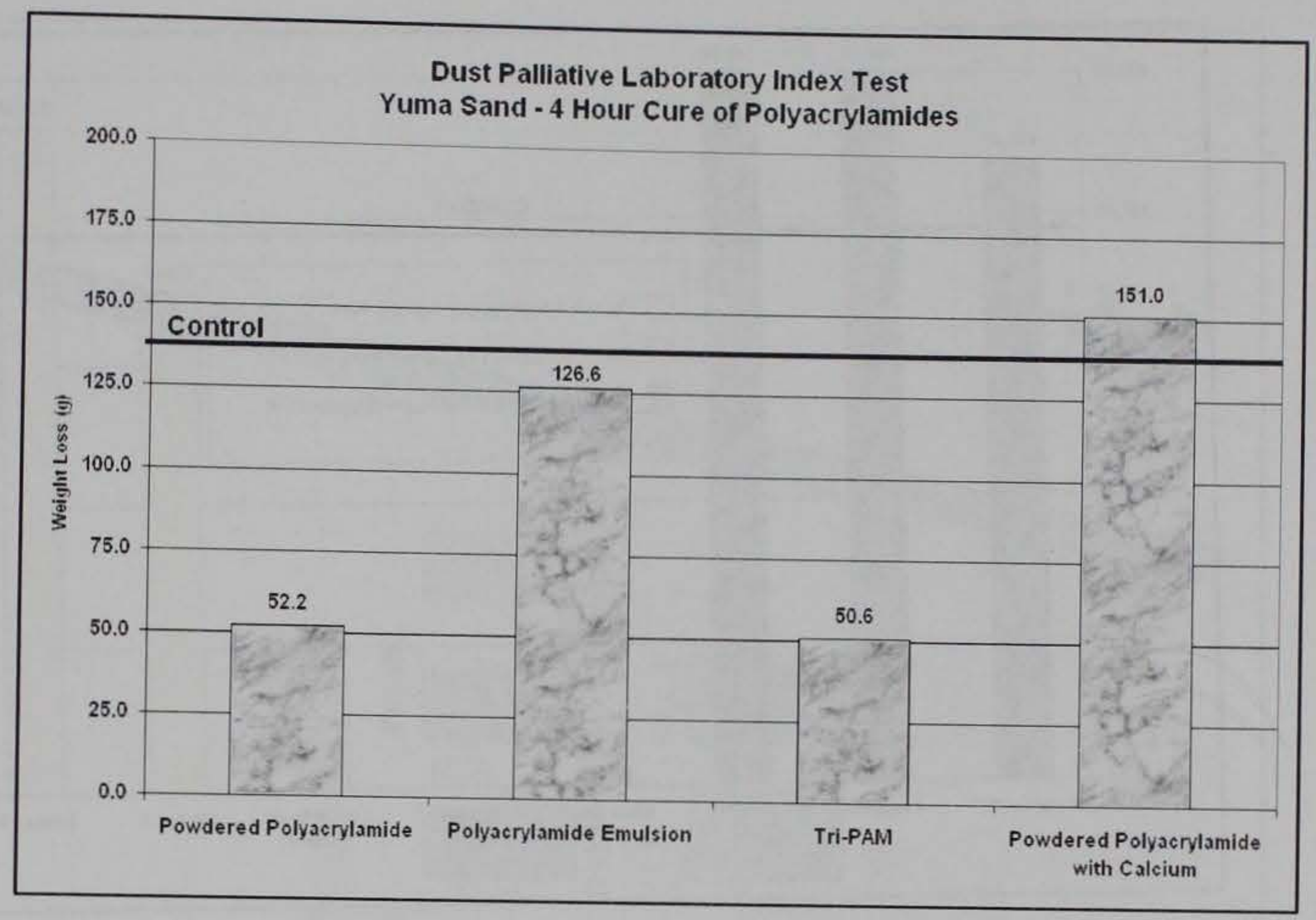

Figure 4. Air impingement results for 4-hr cured MCWL polyacrylamide palliatives

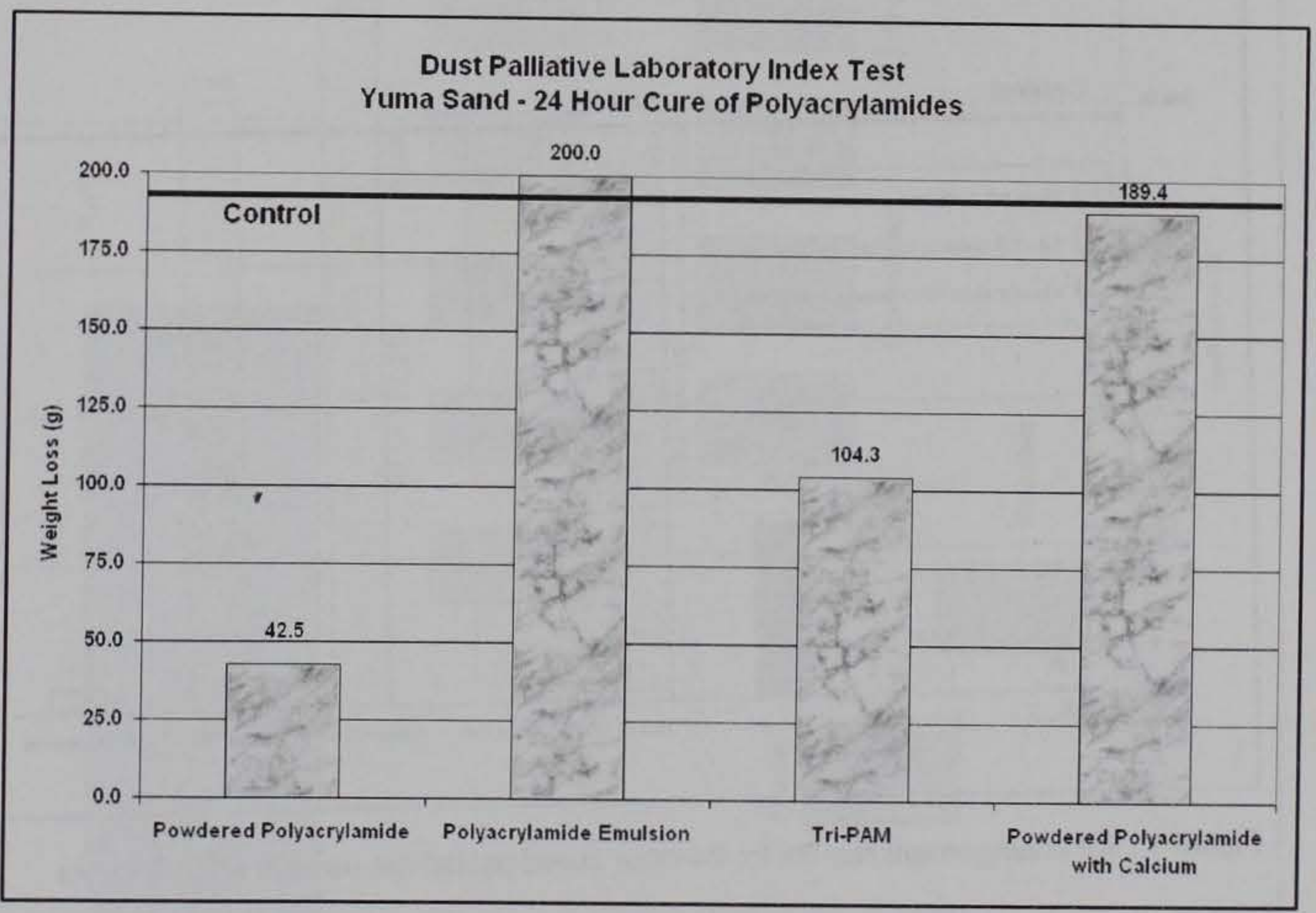

Figure 5. Air impingement results for $24-\mathrm{hr}$ cured MCWL polyacrylamide palliatives 


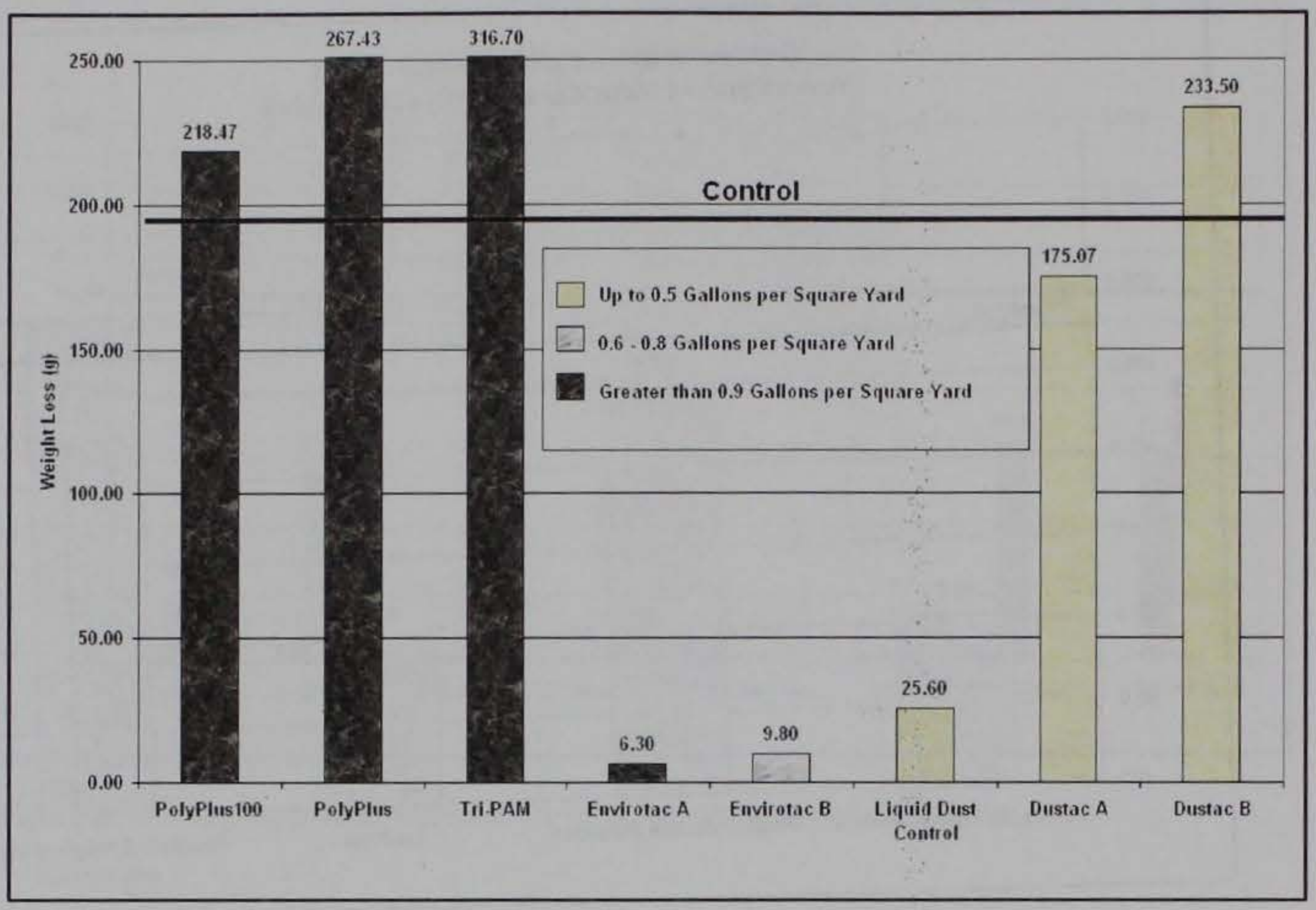

Figure 6. Air impingement results for 24-hr cured palliatives used at MCAS Yuma

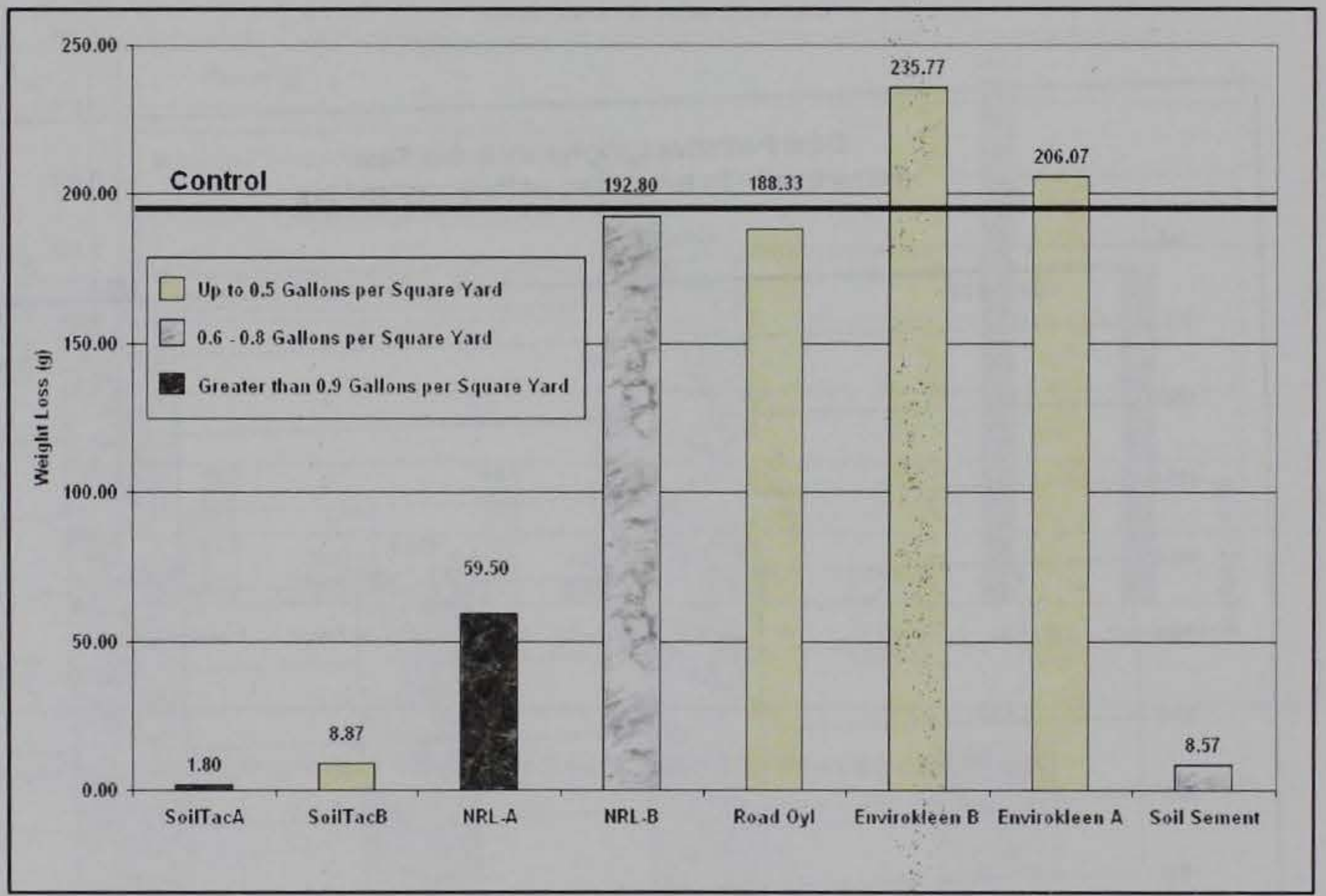

Figure 7. Air impingement results for 24-hour cured palliatives used at MCAS Yuma 


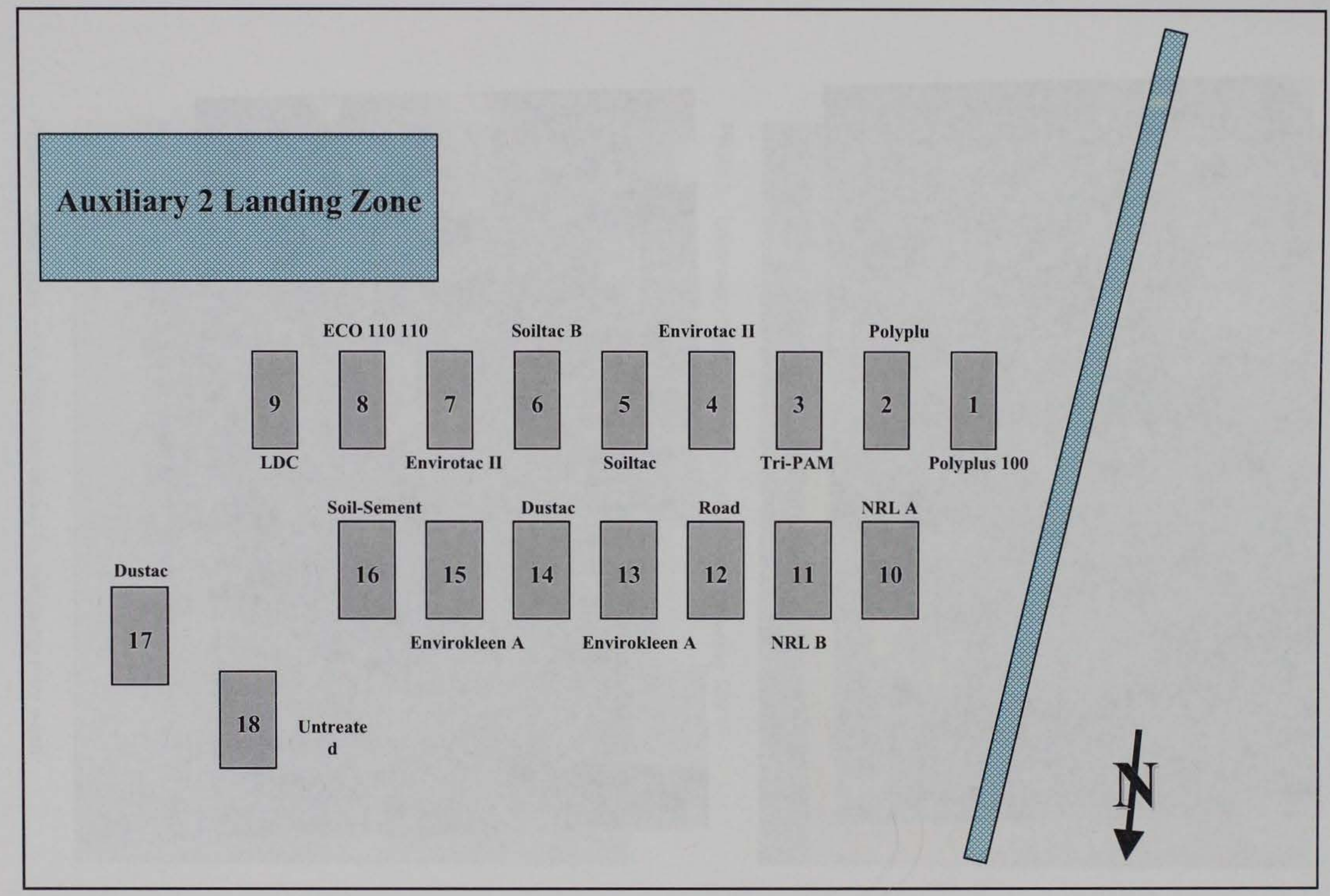

Figure 8. Dust abatement test site layout near Auxiliary 2 Landing Zone, MCAS Yuma 


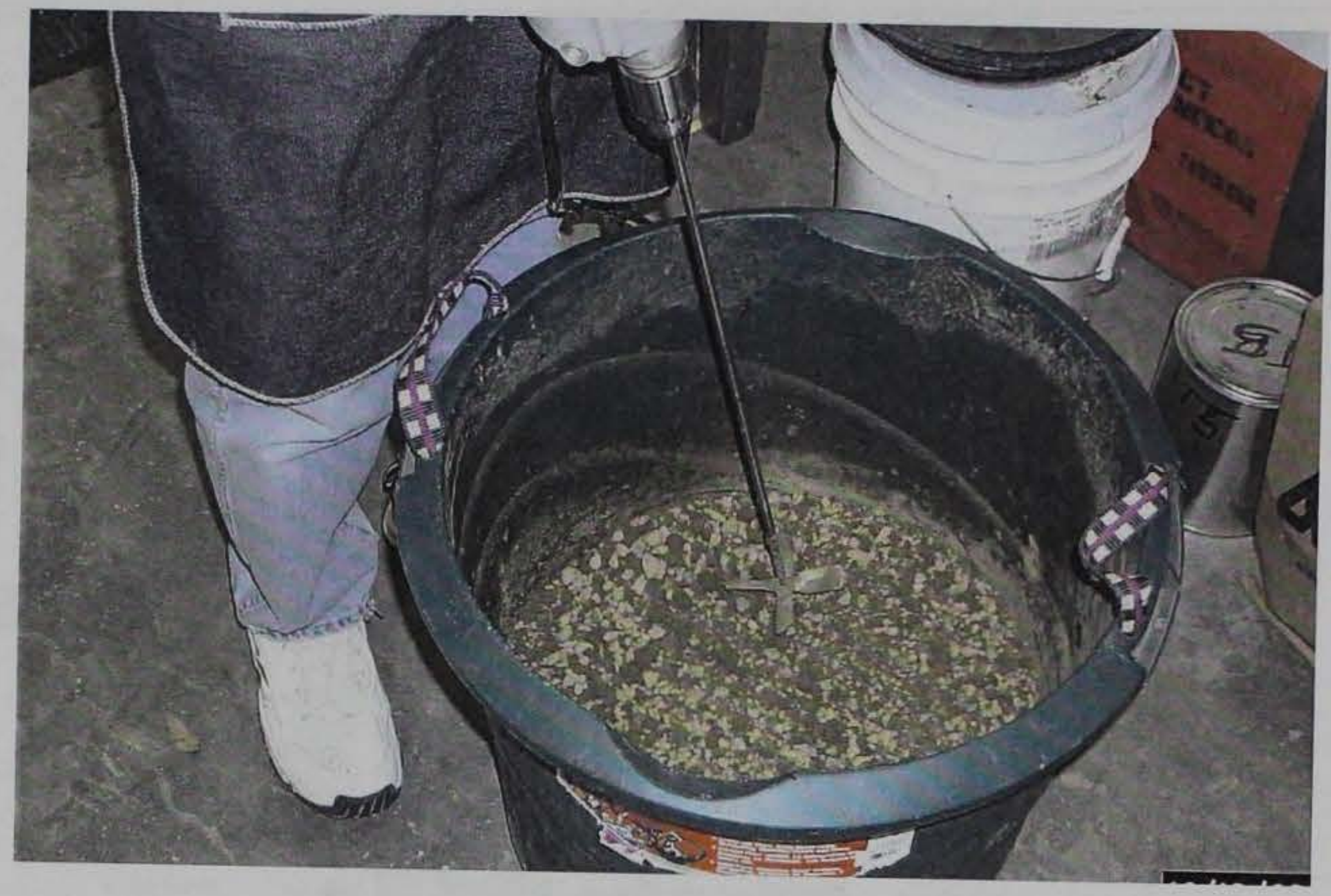

Photo 1. Rotary mixing of palliatives and soil in the laboratory

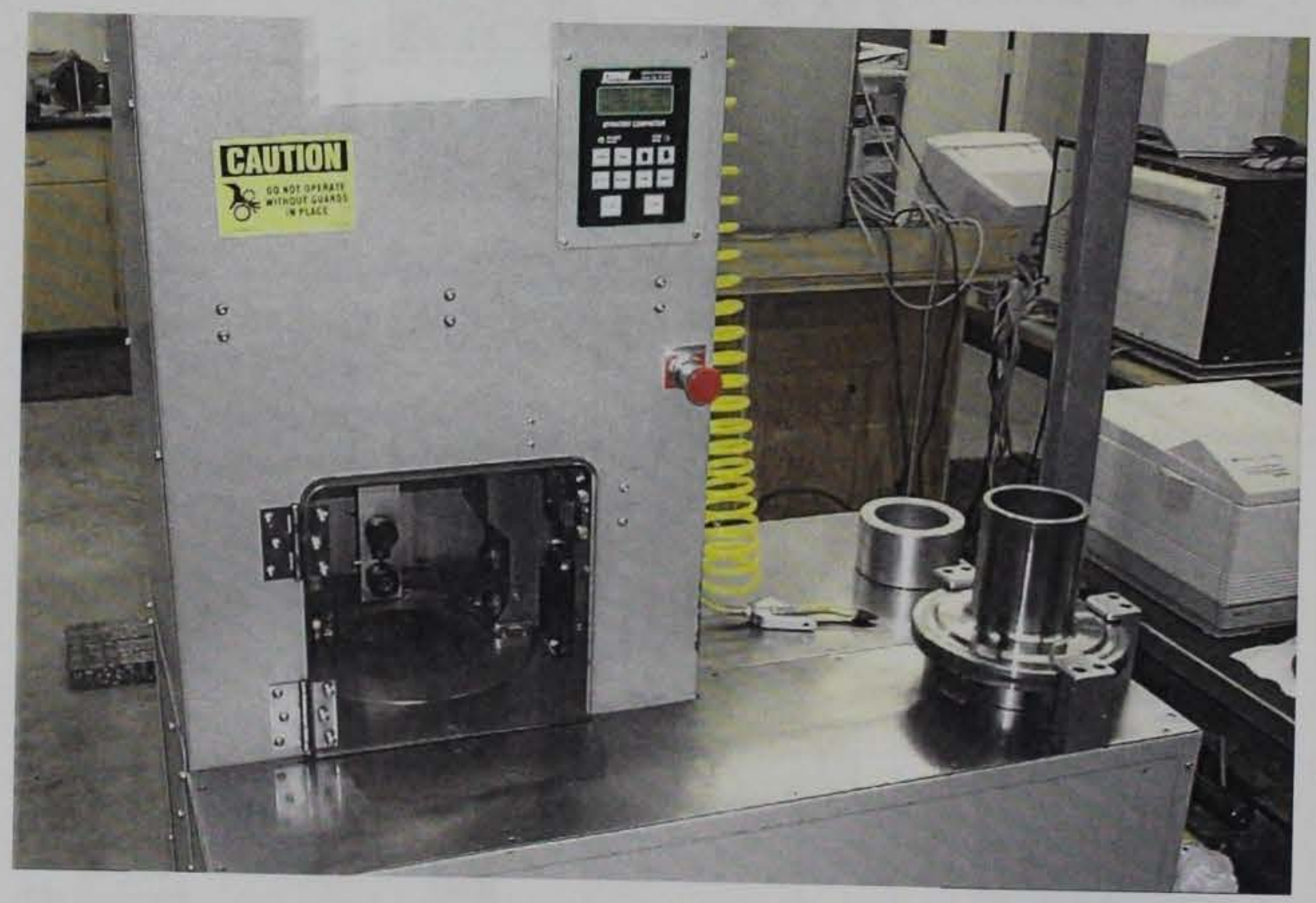

Photo 2. Gyratory testing machine for sample preparation 


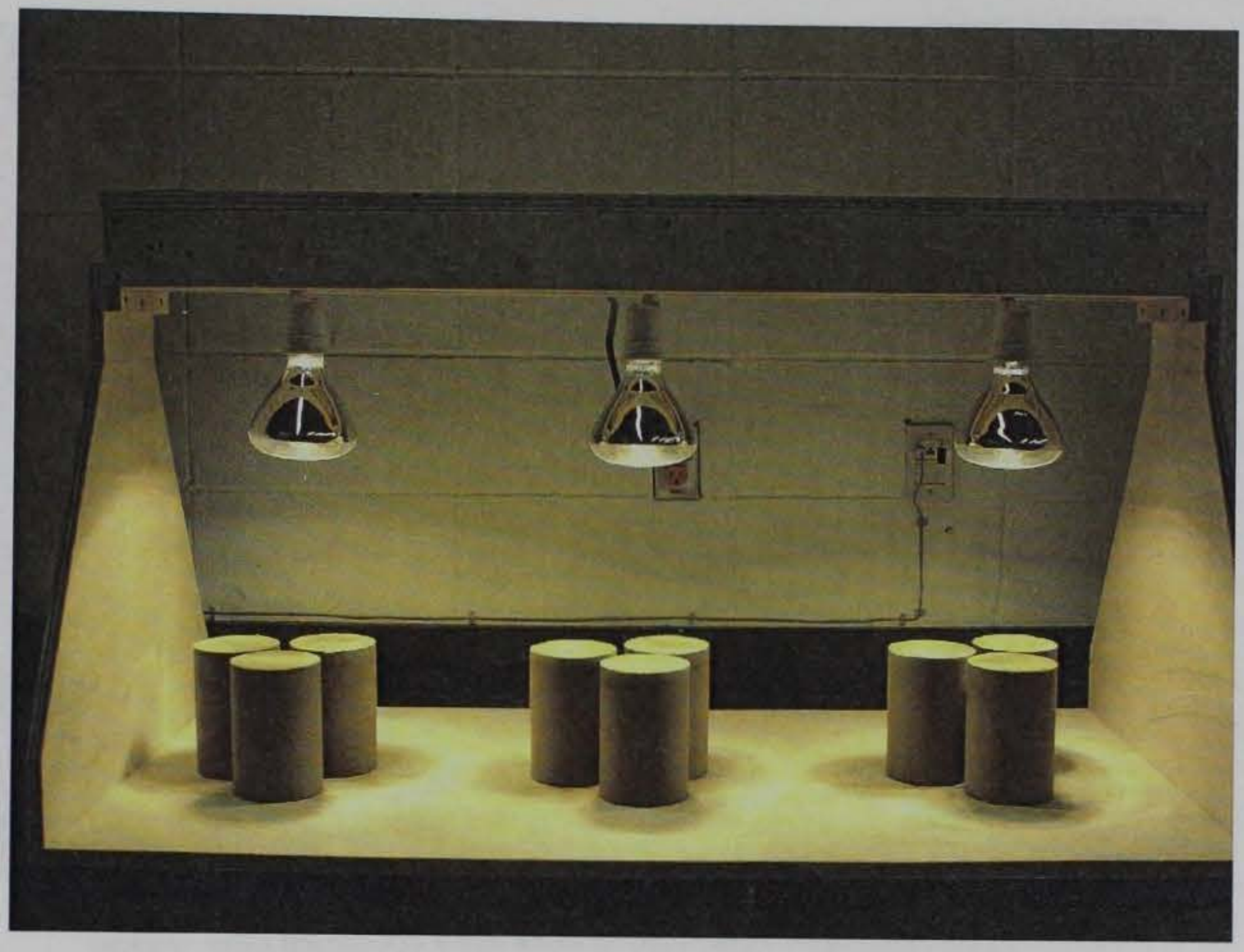

Photo 3. Laboratory curing of treated specimens simulating $120^{\circ} \mathrm{F}$

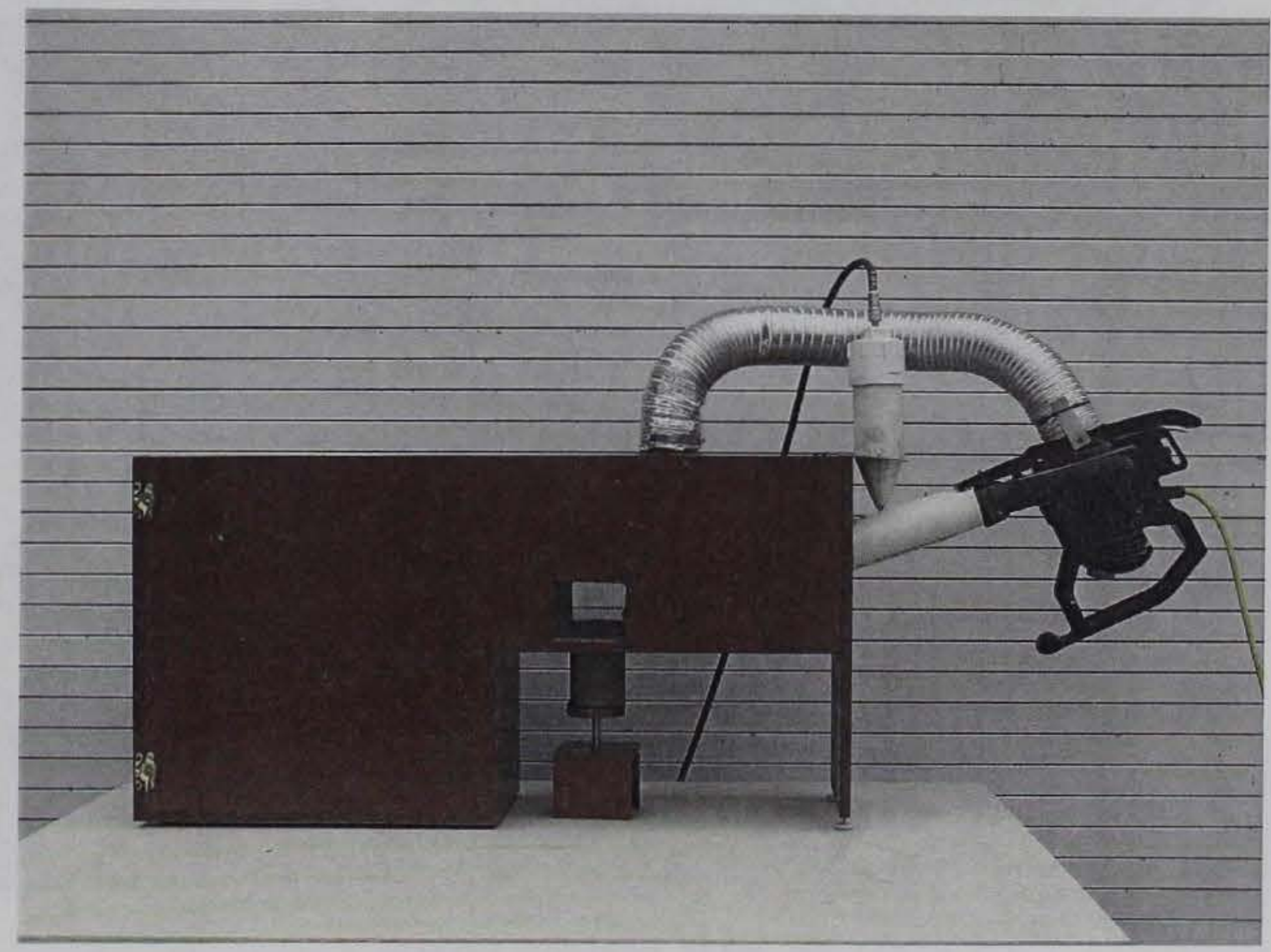

Photo 4. Laboratory air impingement device for simulating rotor wash 


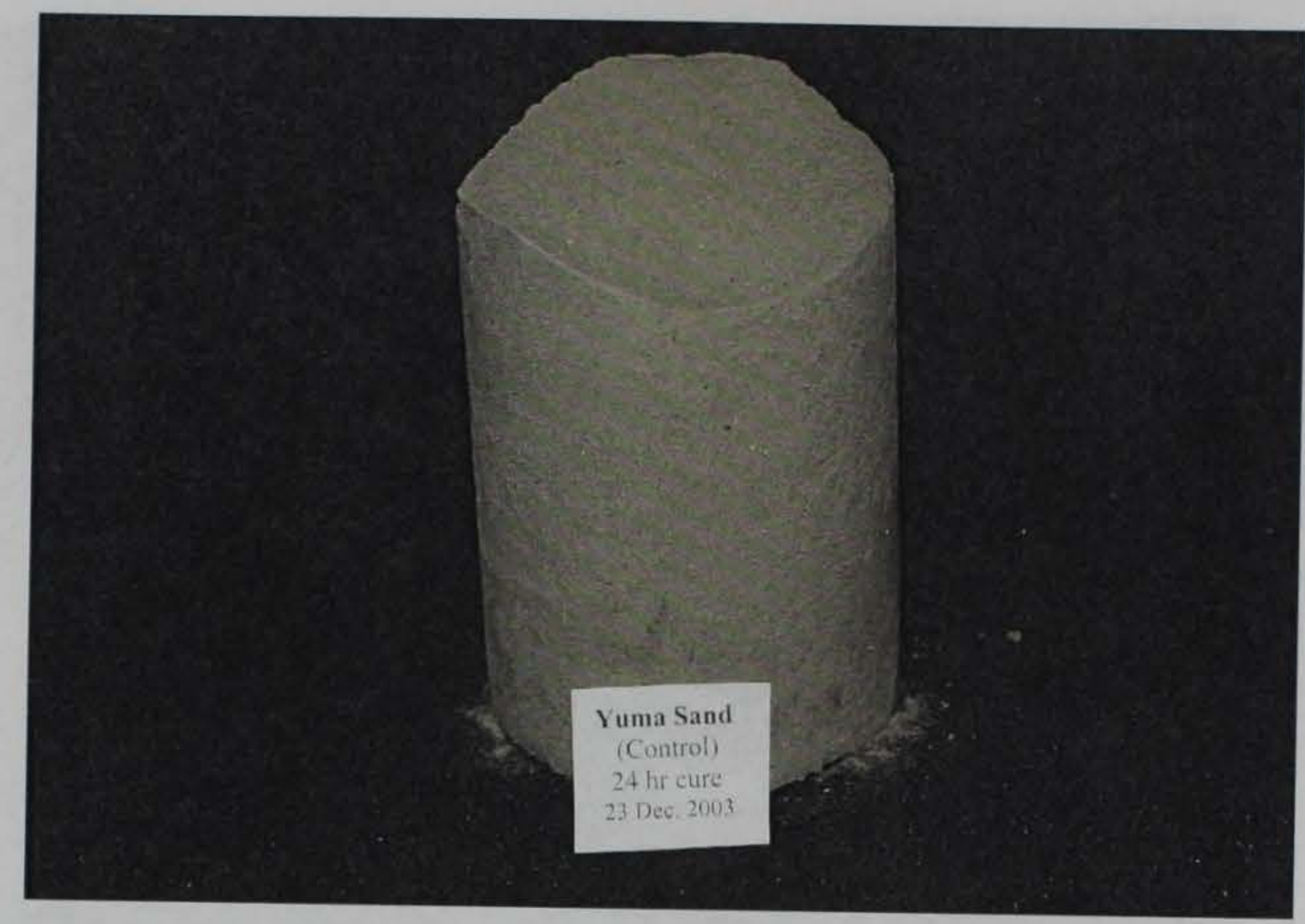

Photo 5. Untreated Yuma sand control laboratory specimen after testing

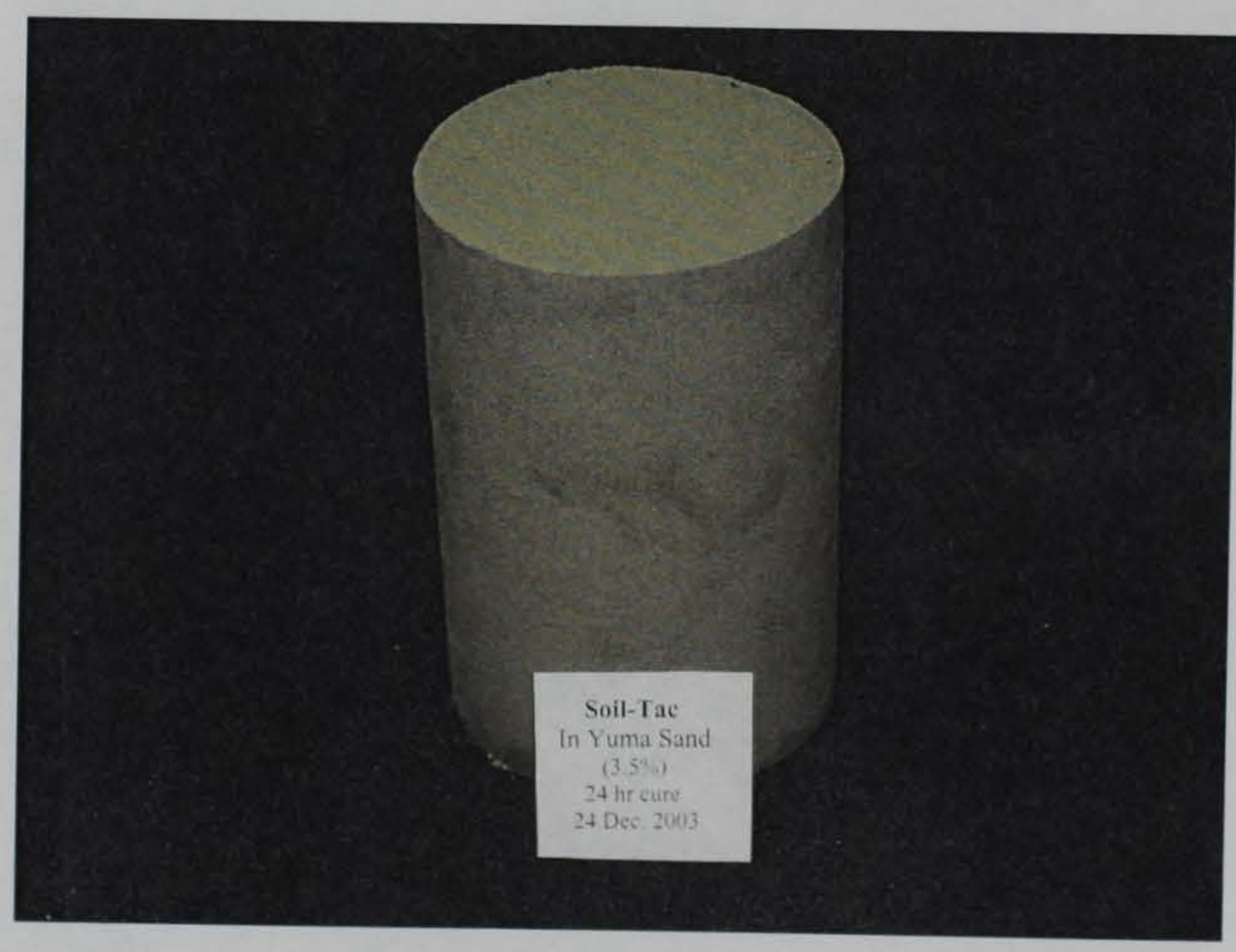

Photo 6. Soiltac(R) specimen (24-hr cure) after testing 


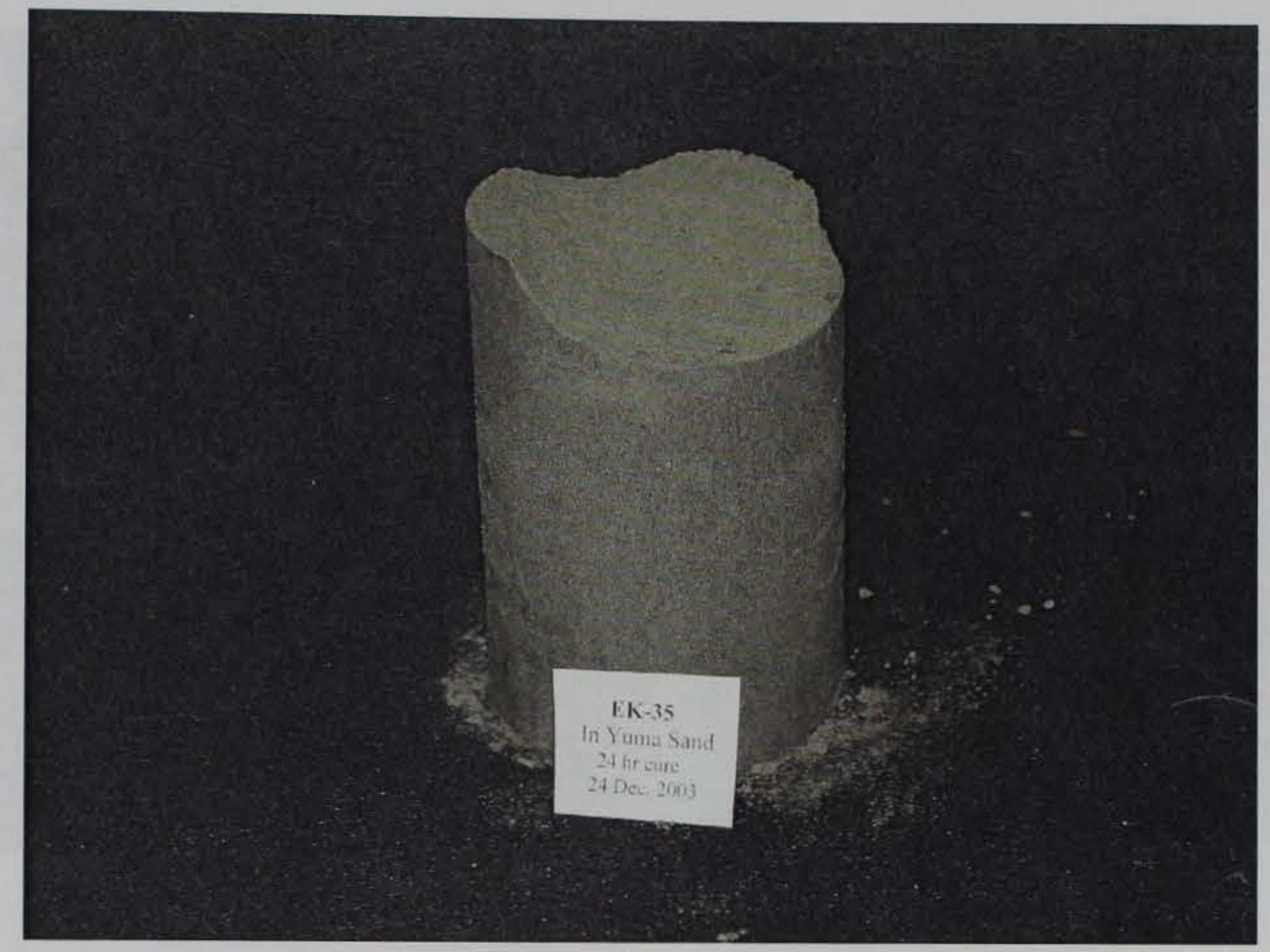

Photo 7. EK-35 specimen (24-hr cure) after testing

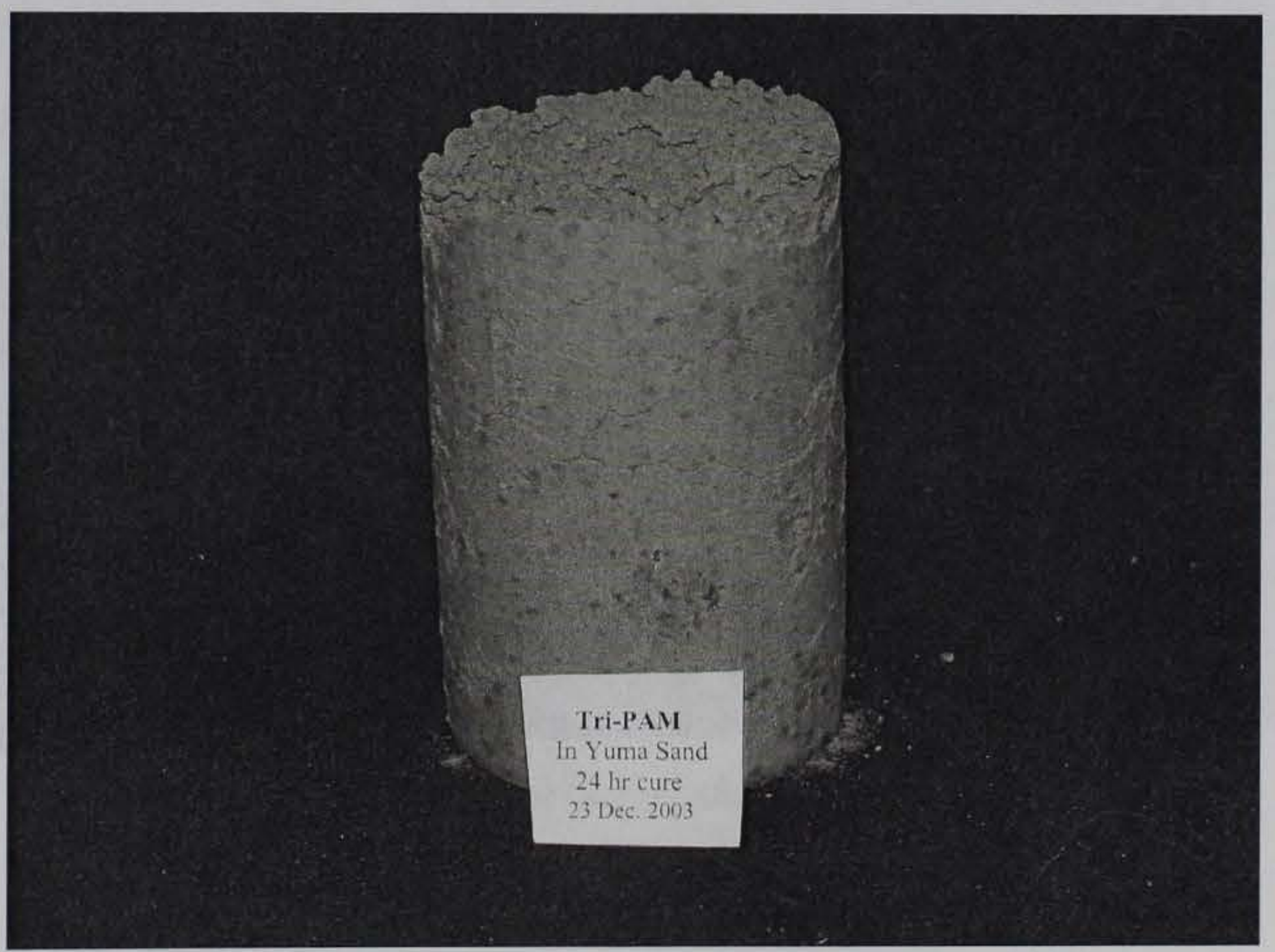

Photo 8. Tri-PAM specimen (24-hr cure) after testing 


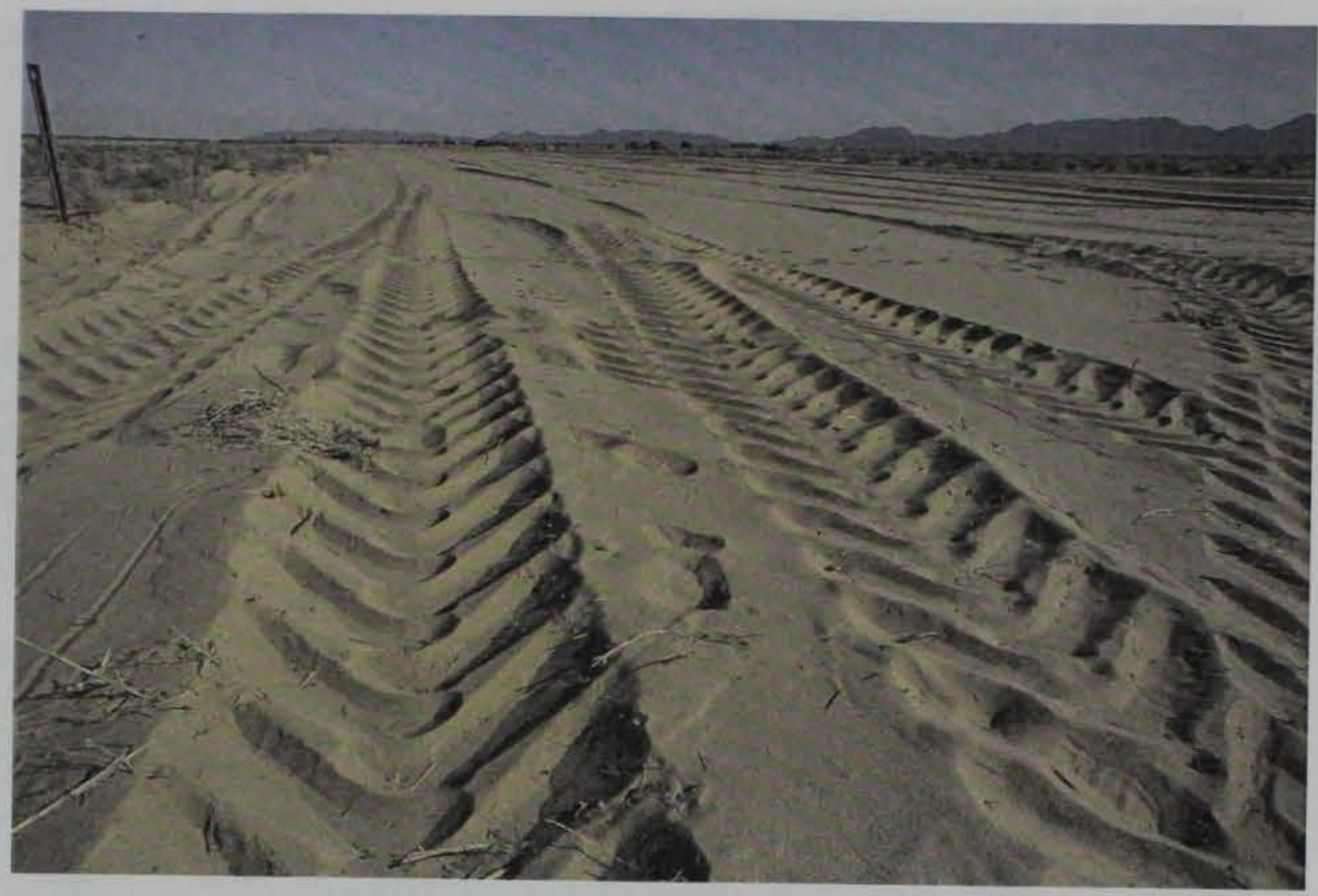

Photo 9. Graded site prior to product application

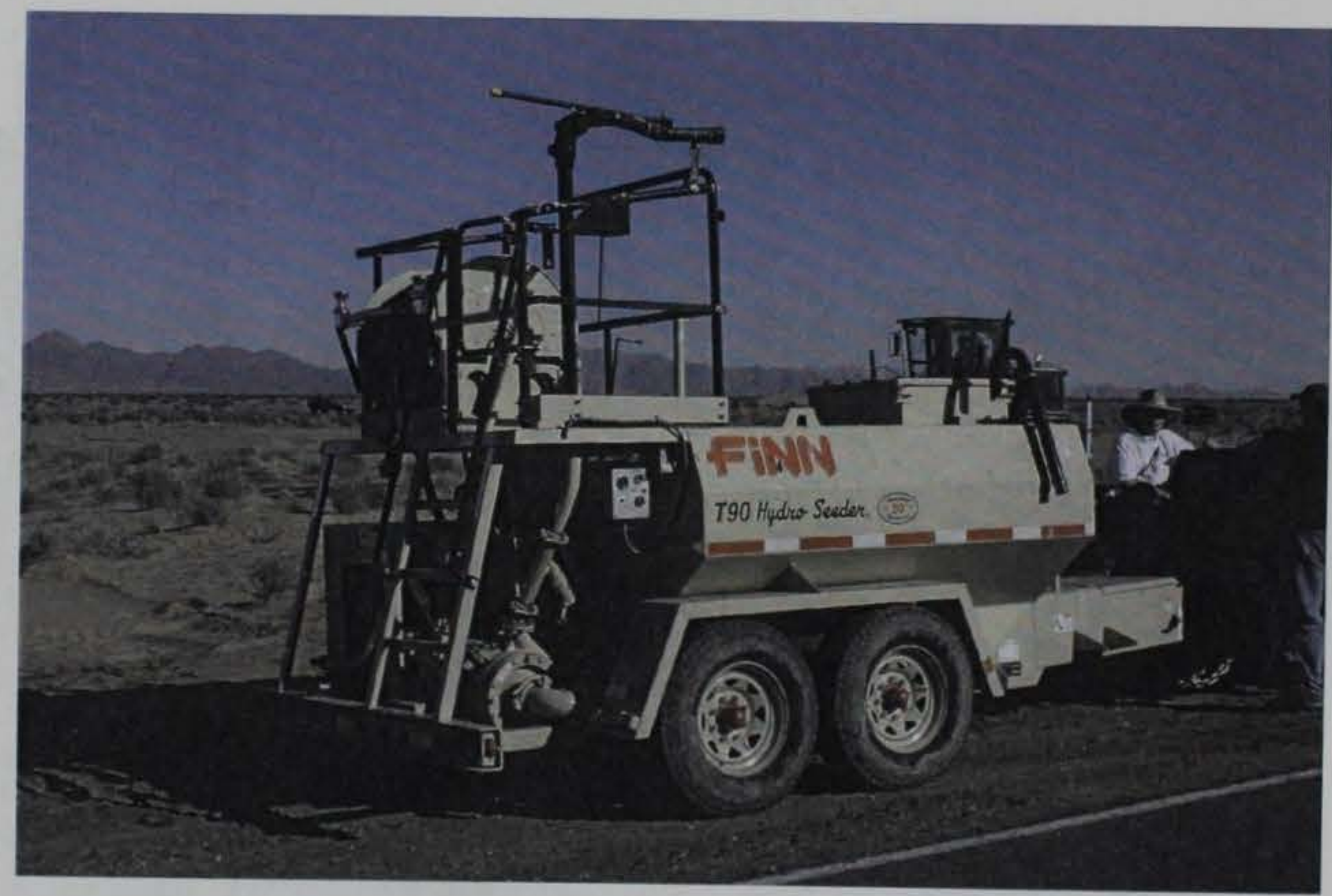

Photo 10. Finn T-90 hydroseeder 


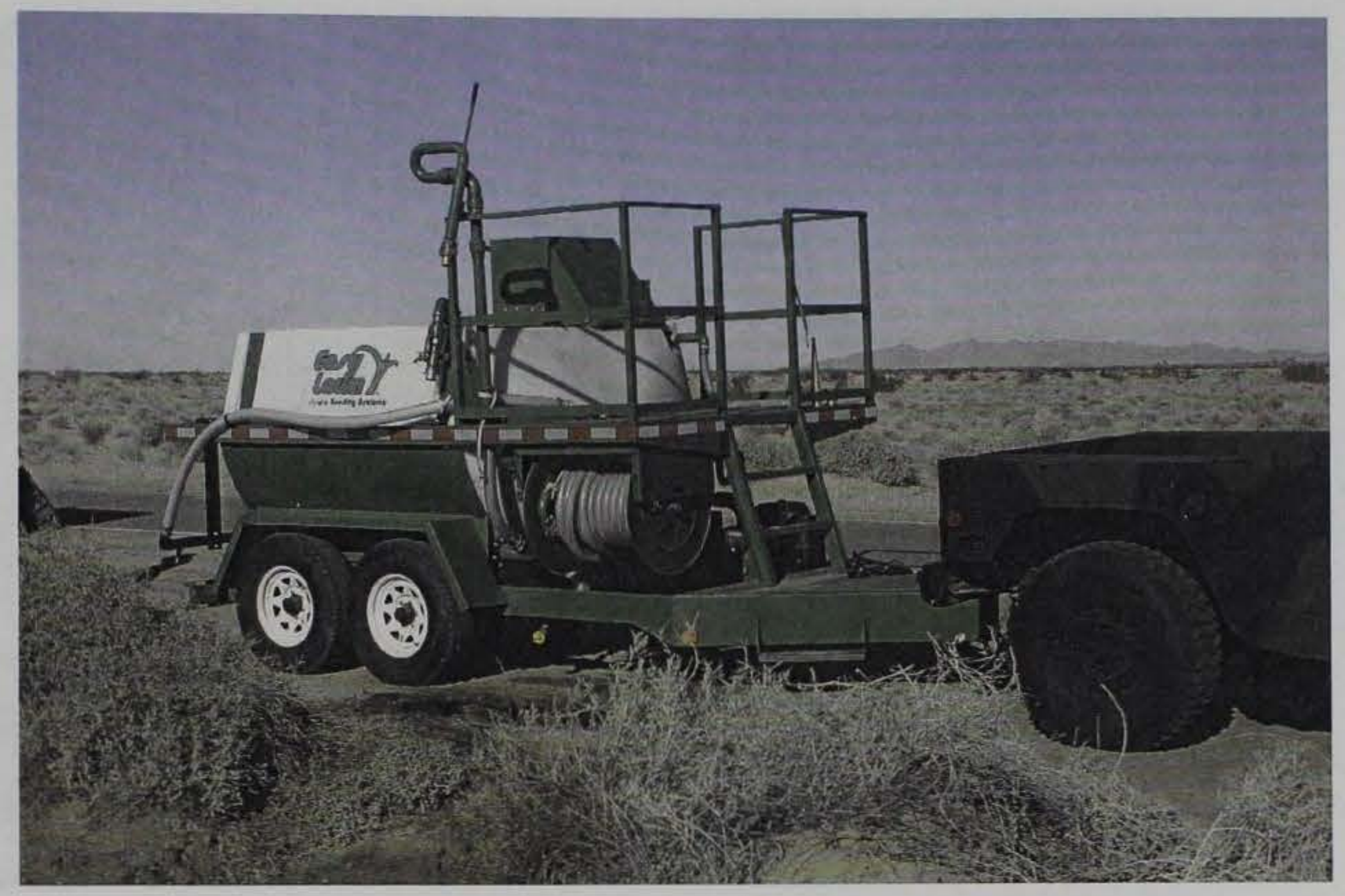

Photo 11. Easy Lawn L-90 hydroseeder

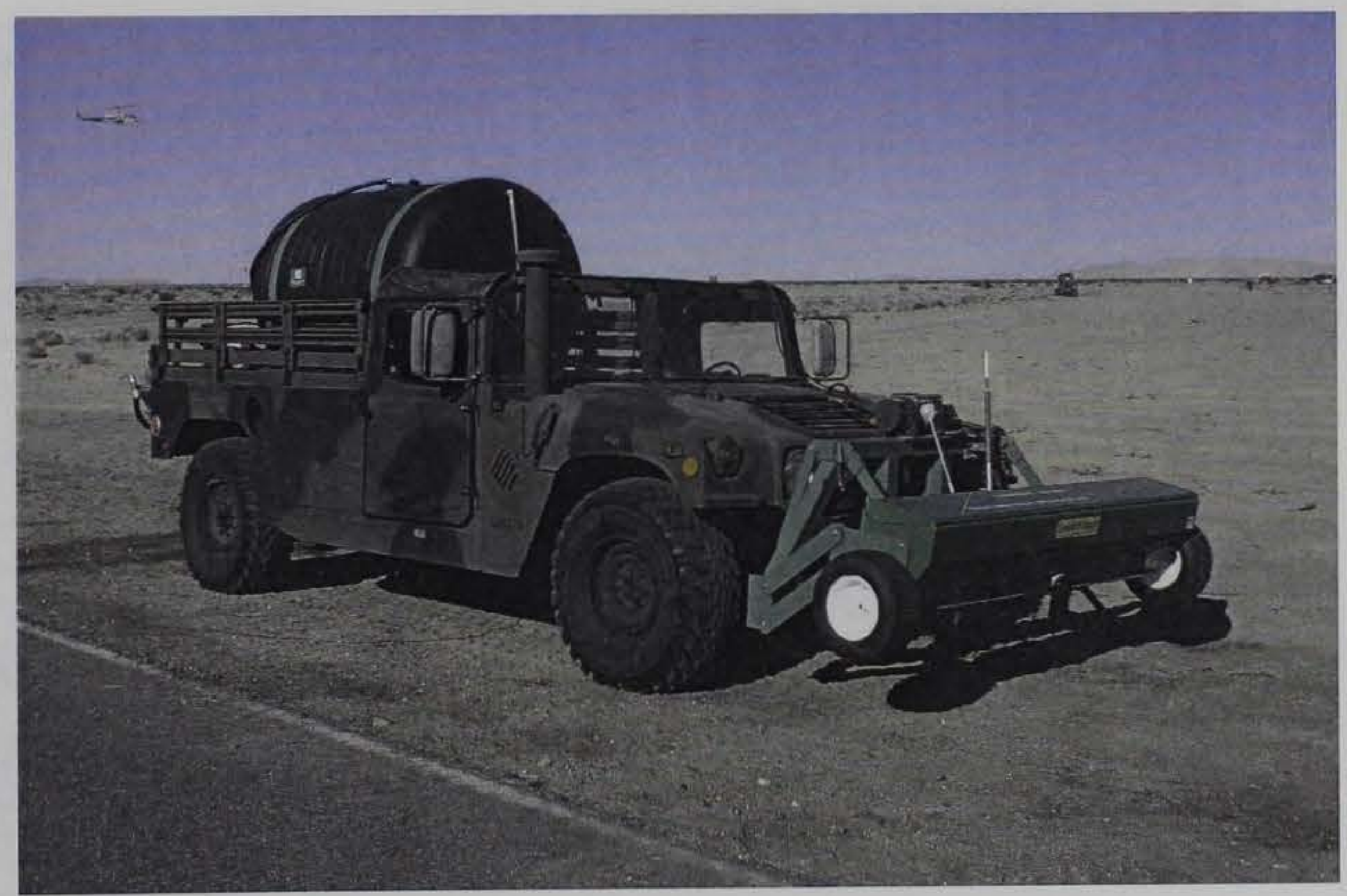

Photo 12. Marine Wing Support Group (MSWG) 27 Dust Abatement Vehicle (DAV) 


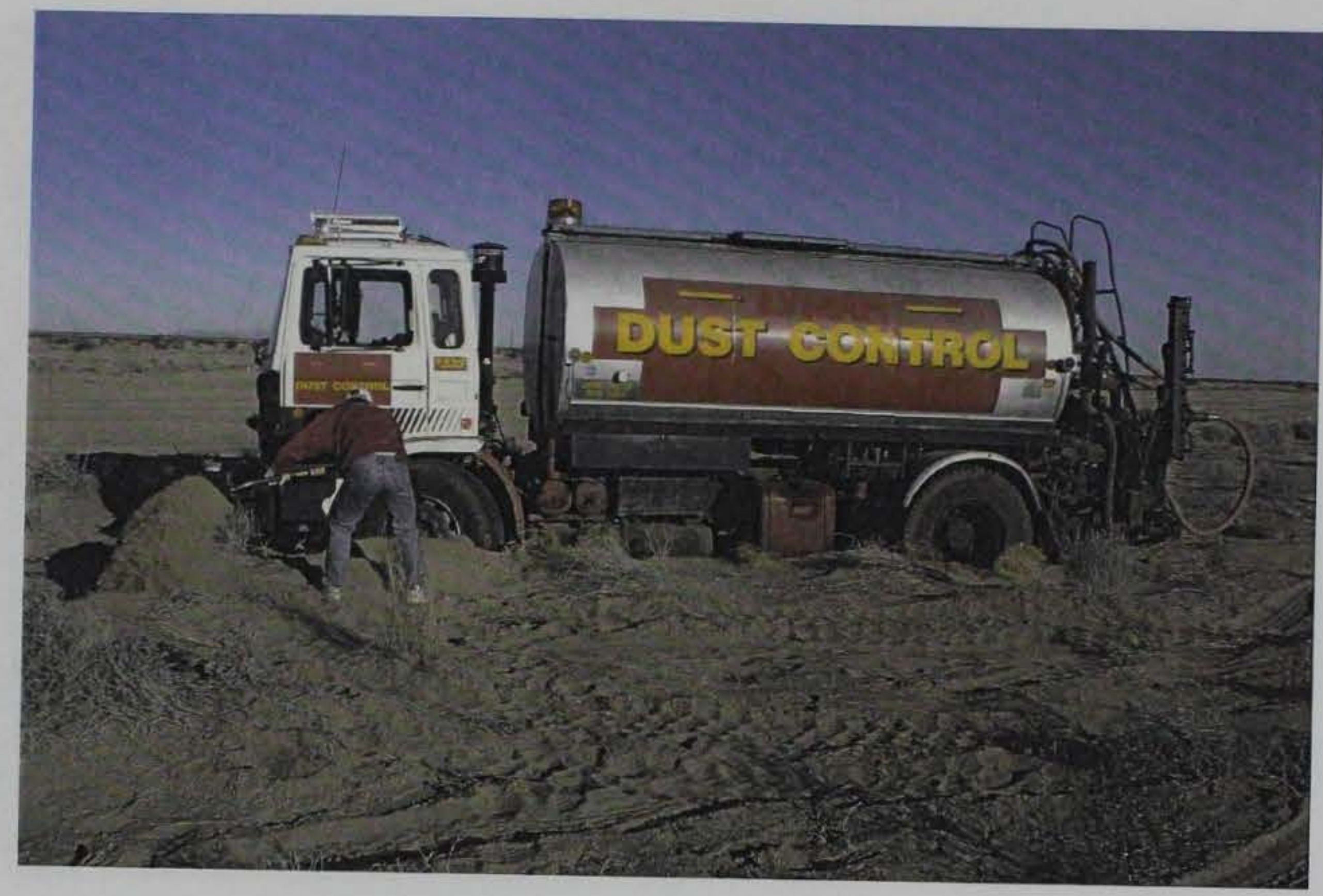

Photo 13. Computerized rate control (CRC) distributor truck stuck in loose sand

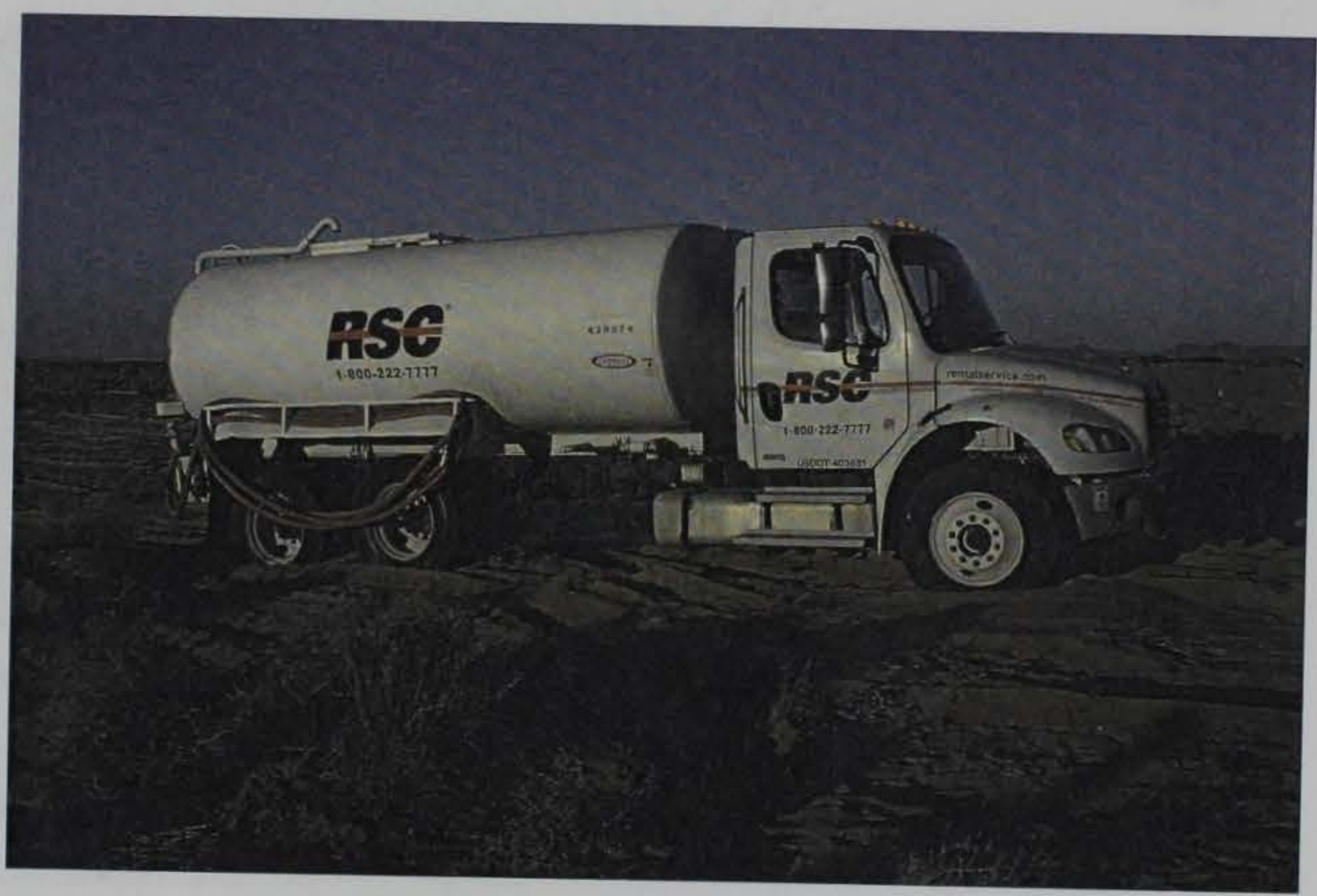

Photo 14. Commercial water truck stuck in loose sand 


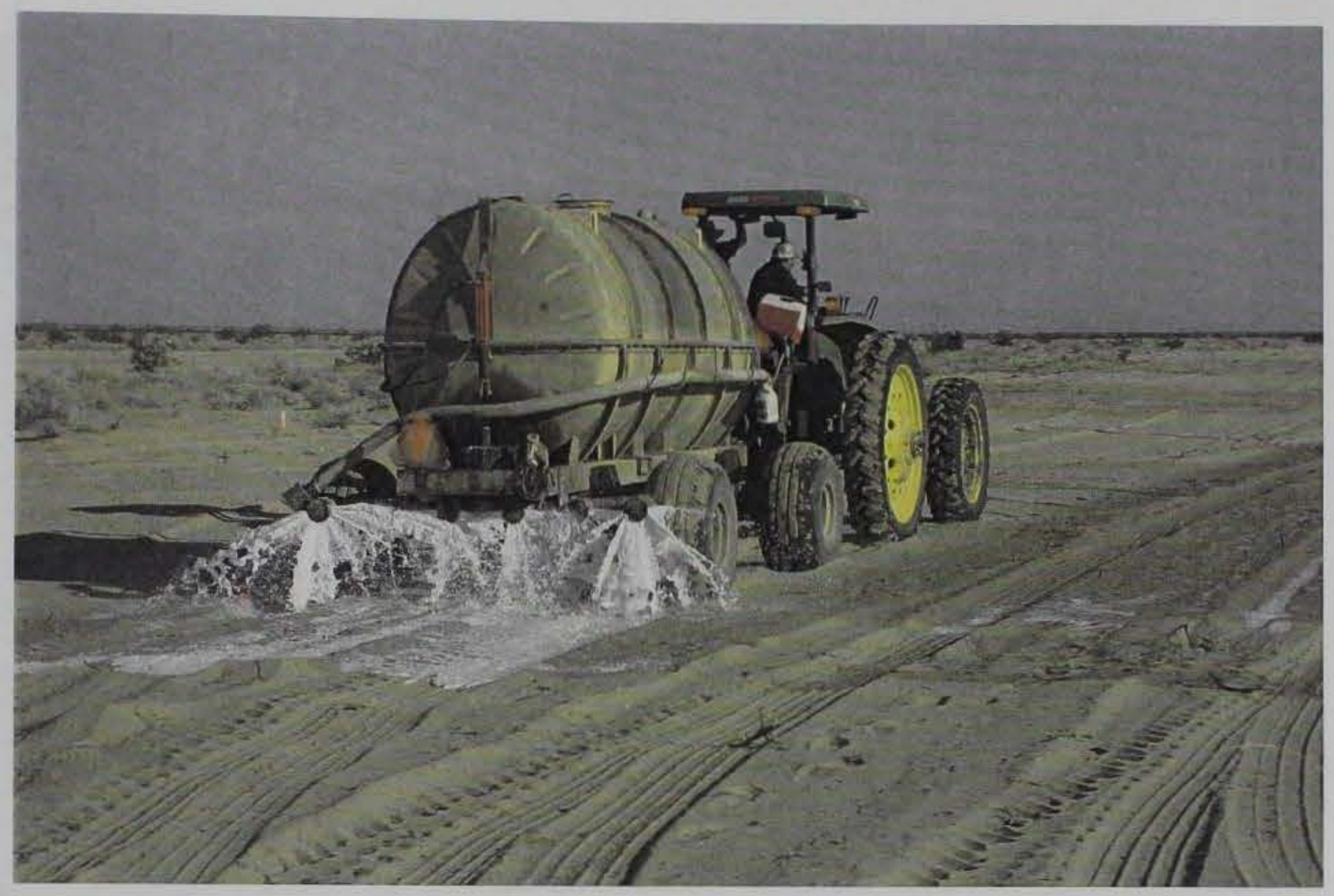

Photo 15. Agricultural trailer with flotation tires

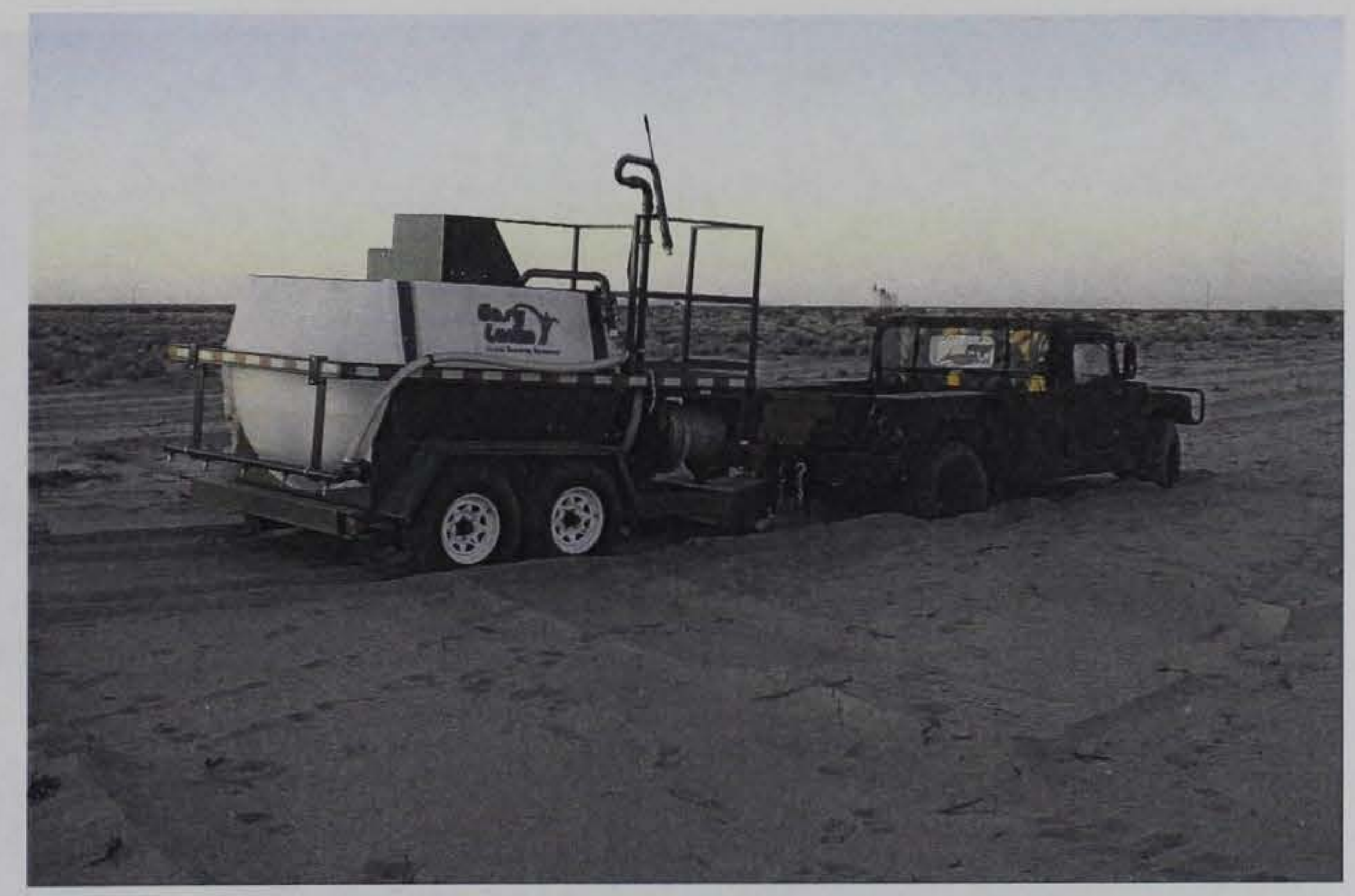

Photo 16. HMMWV and Easy Lawn hydroseeder immobilized in loose sand 


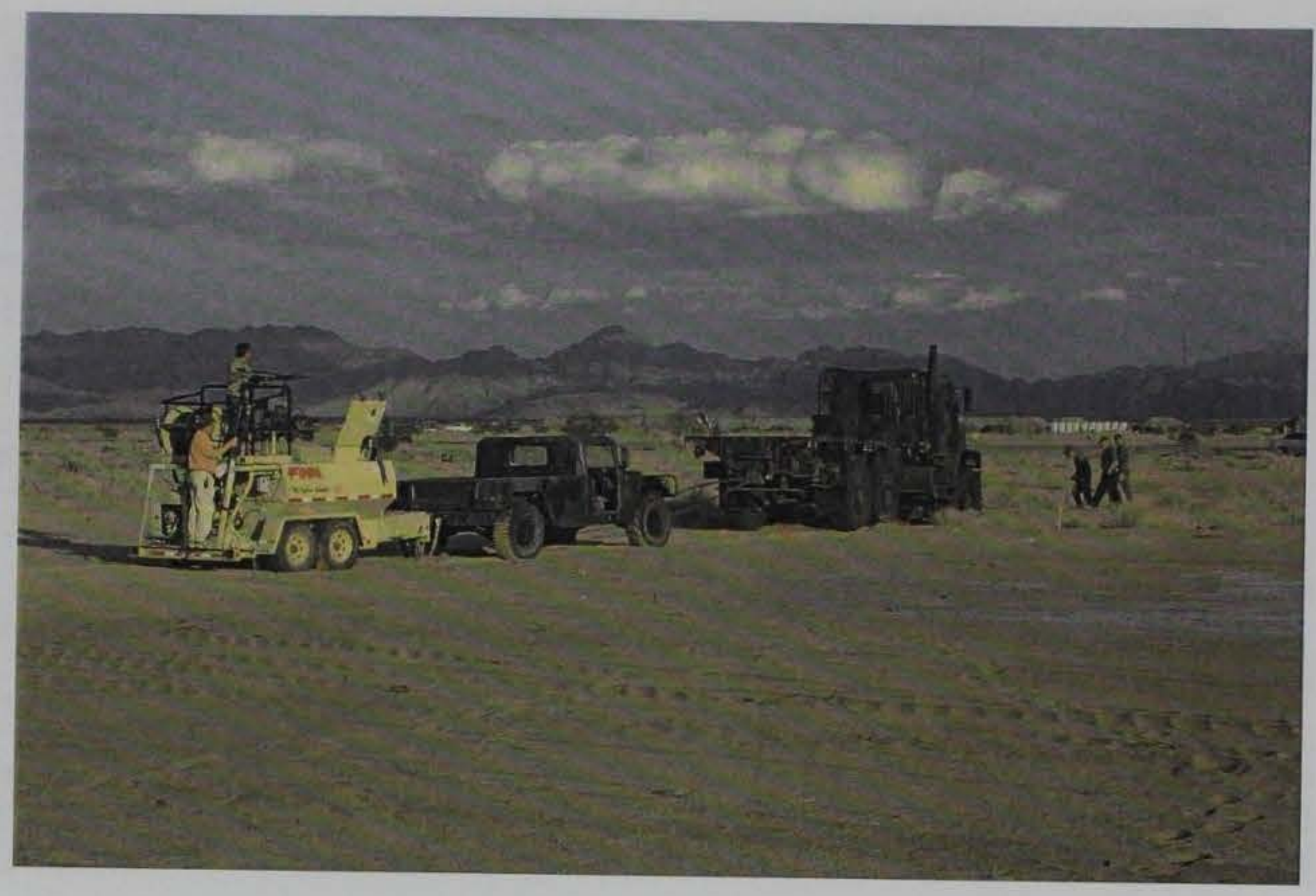

Photo 17. MTVR towing HMMWV and Finn T-90 hydroseeder due to loose sand

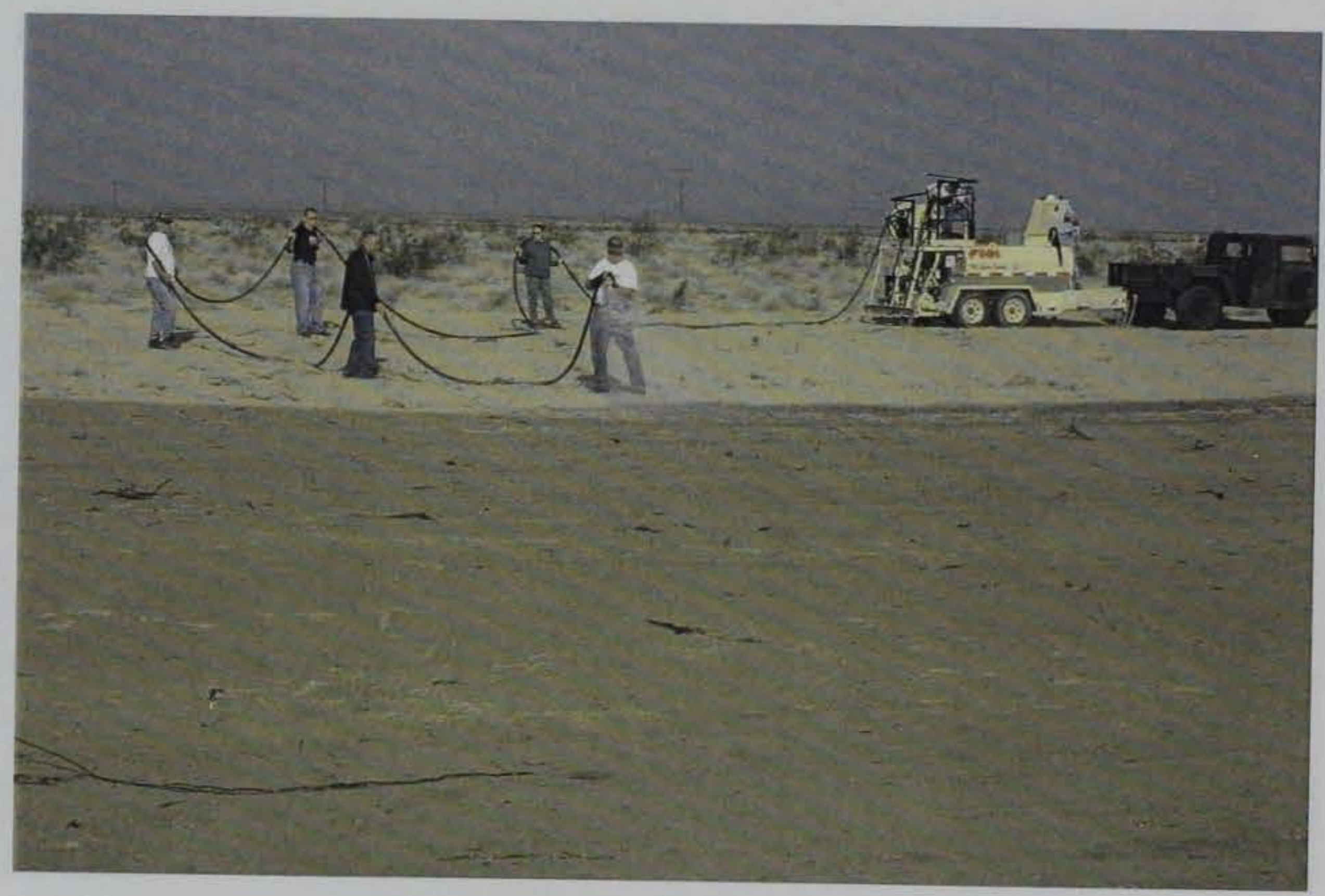

Photo 18. Hose application of dust palliatives using the T-90 Finn hydroseeder 


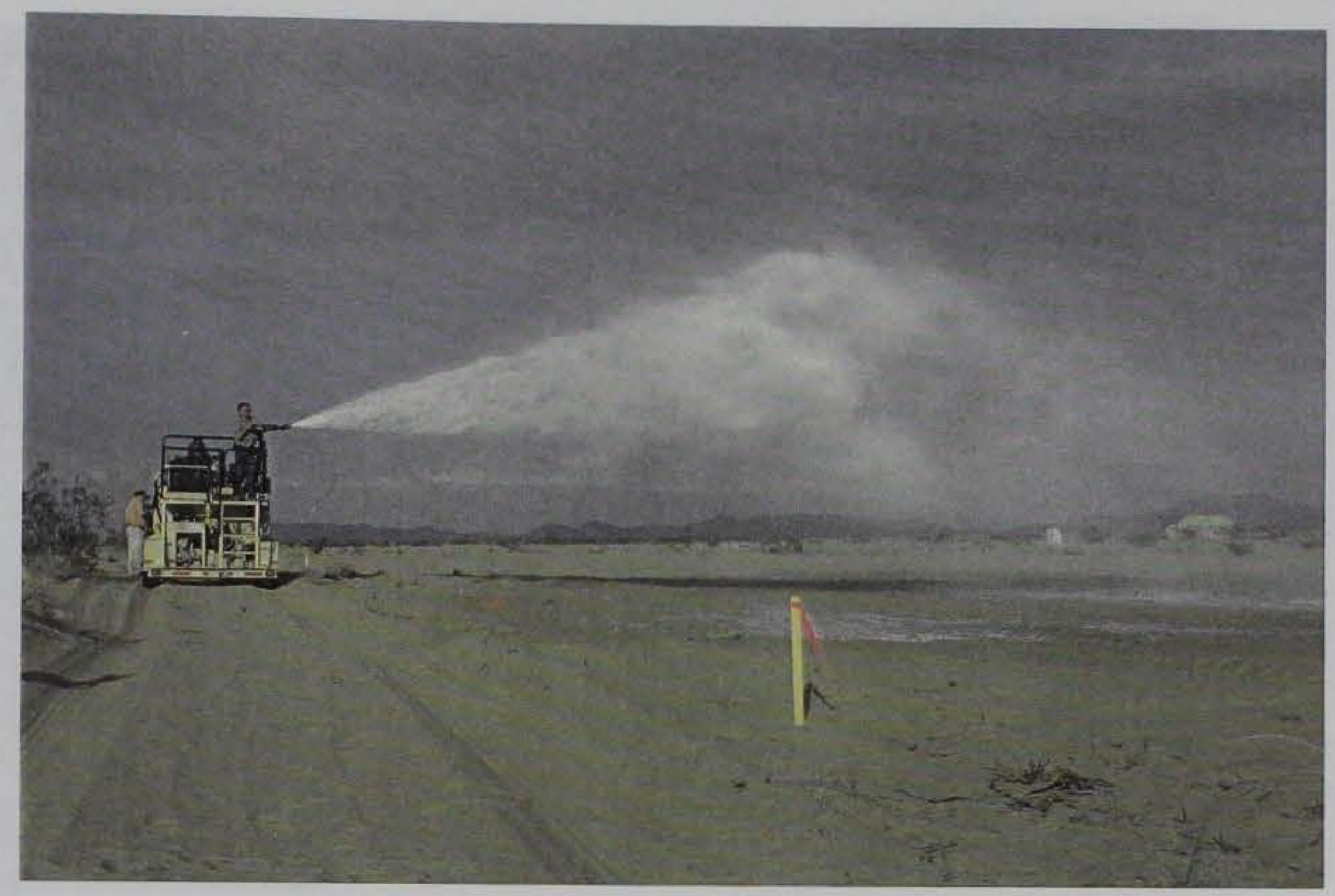

Photo 19. Tower gun application of dust palliatives using the T-90 Finn hydroseeder

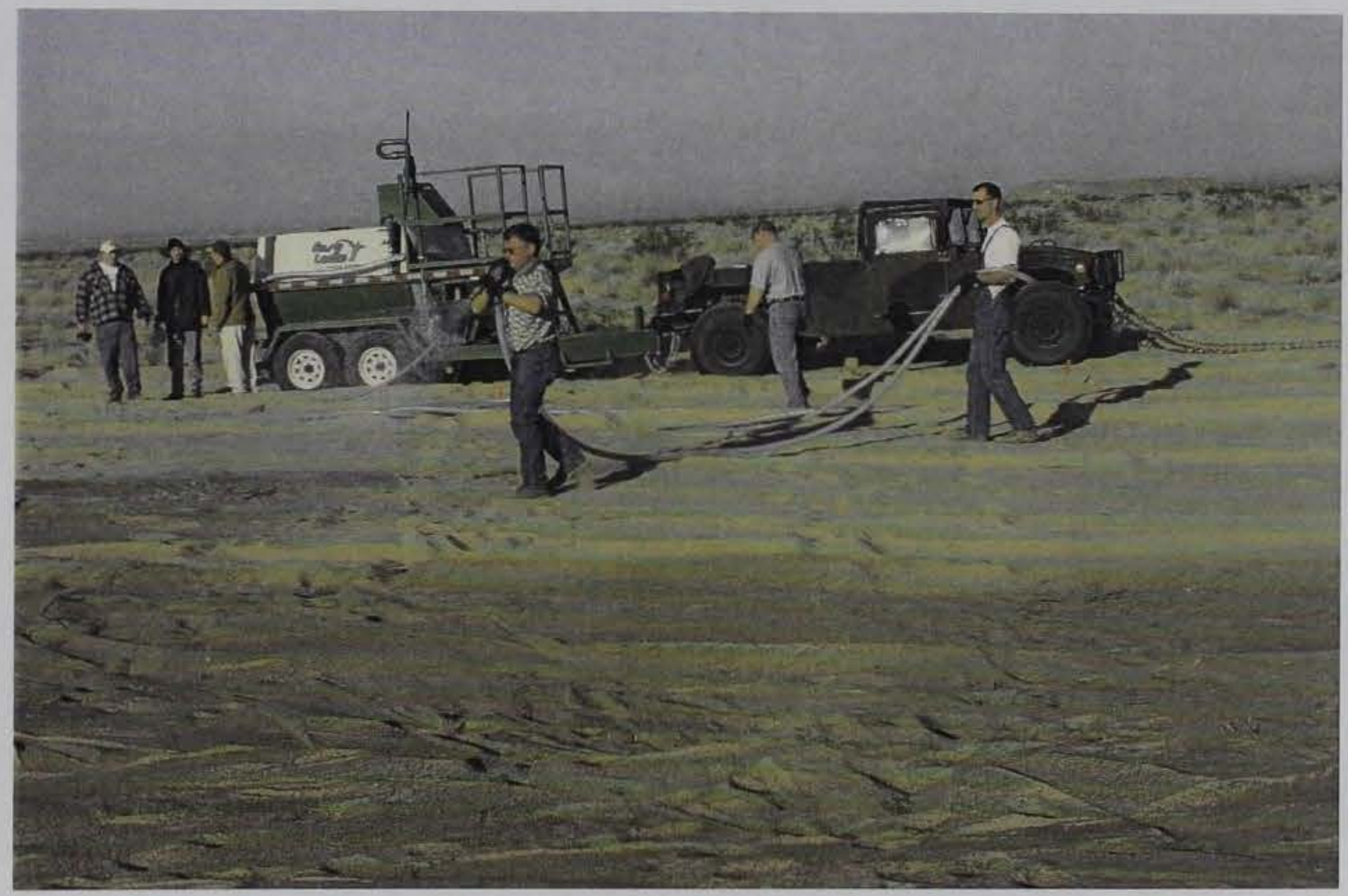

Photo 20. Hose application of dust palliatives using the L-90 Easy Lawn hydroseeder 


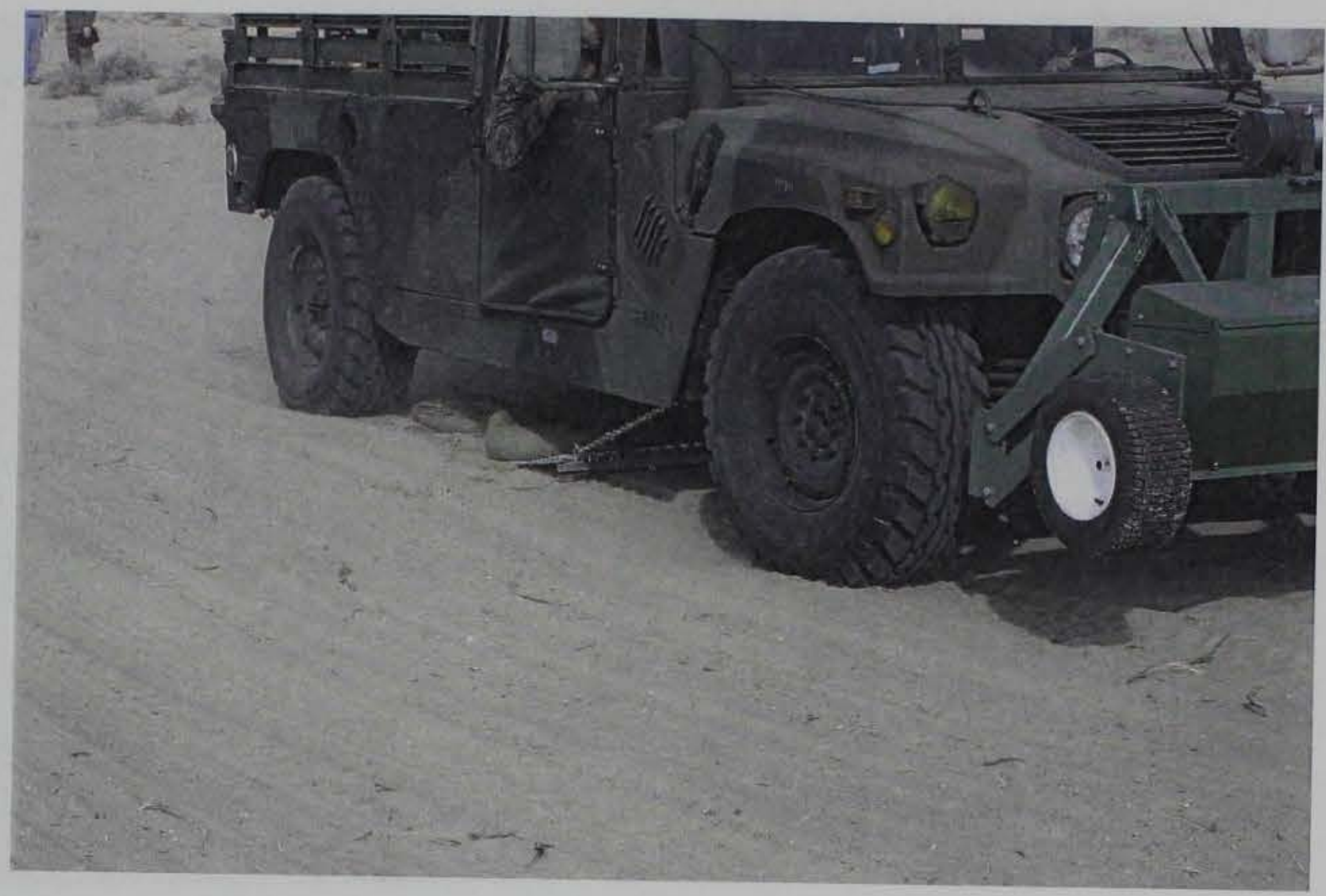

Photo 21. Initial site leveling using the DAV and drag rake

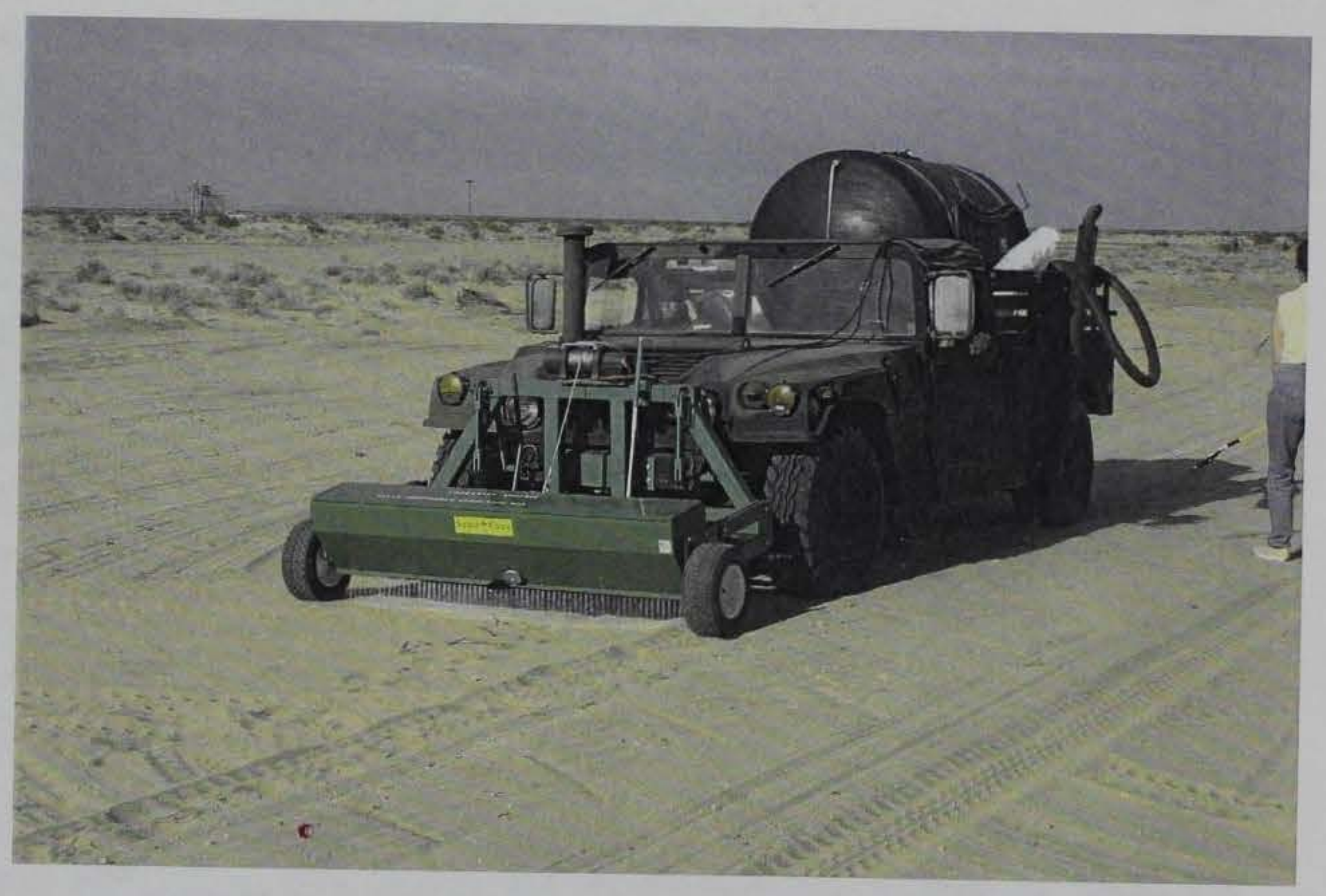

Photo 22. Dry palliative application using DAV's drop spreader 


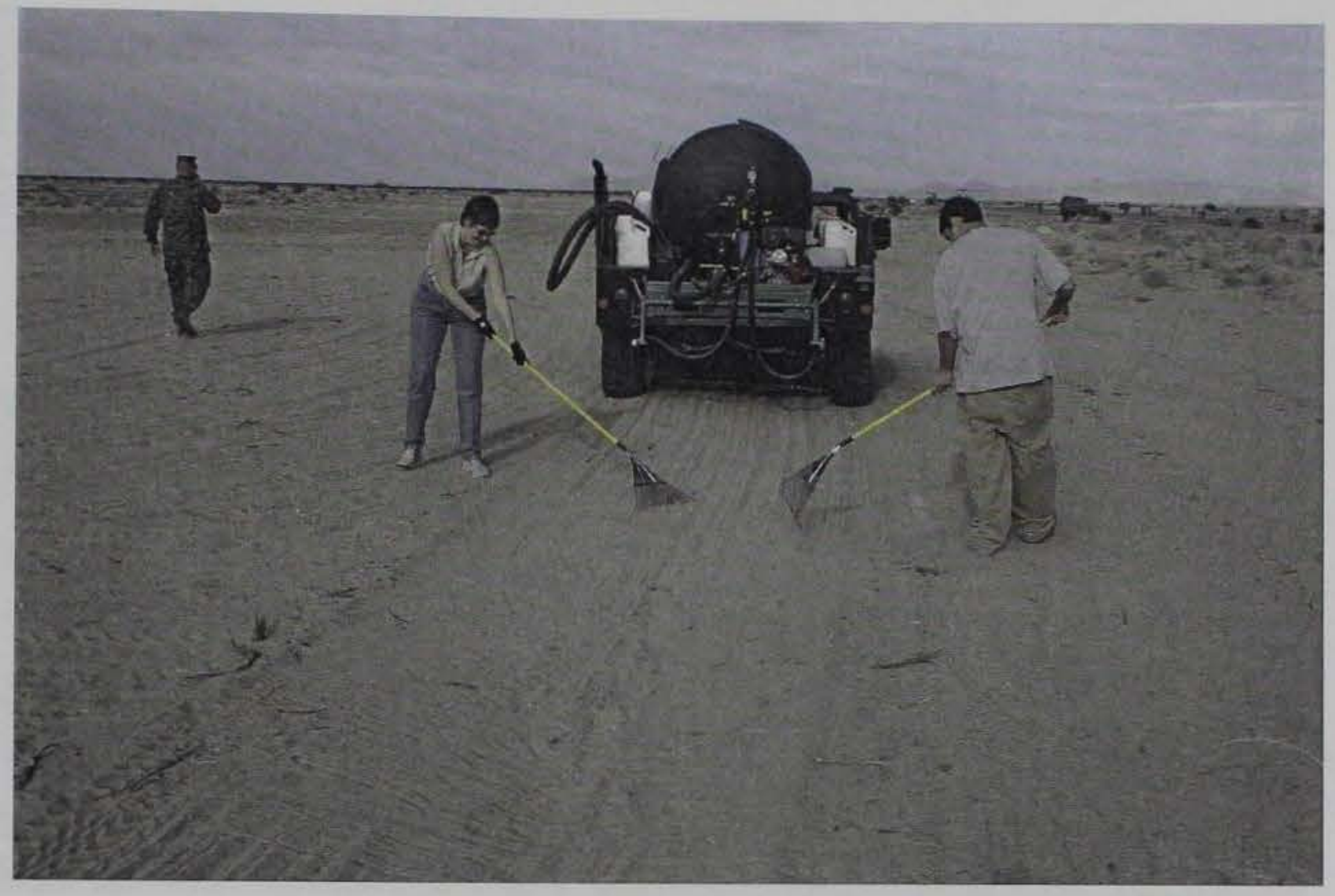

Photo 23. Hand raking dry palliative into the surface behind the DAV application

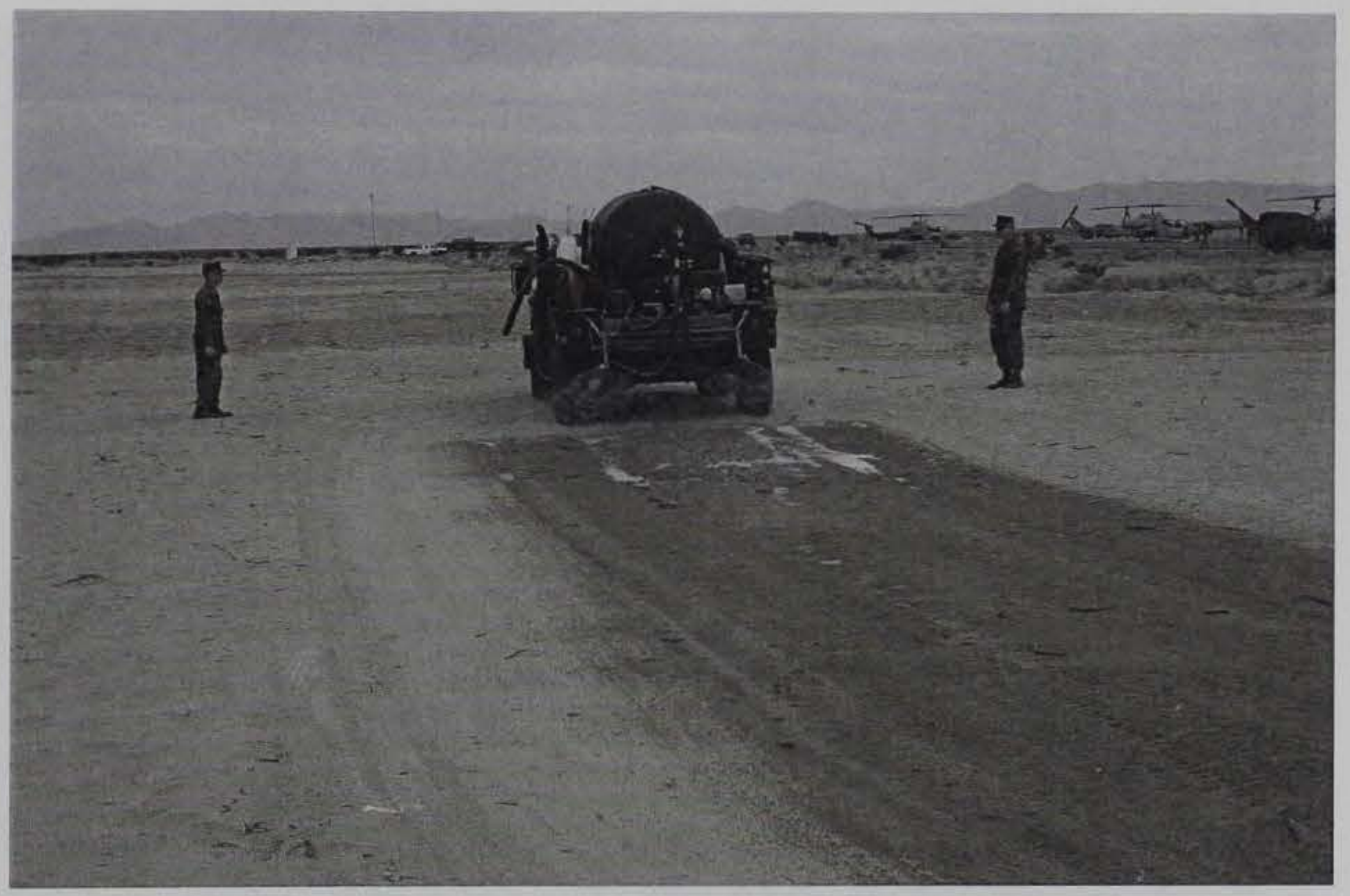

Photo 24. Application of water and PAM emulsion using the DAV system 


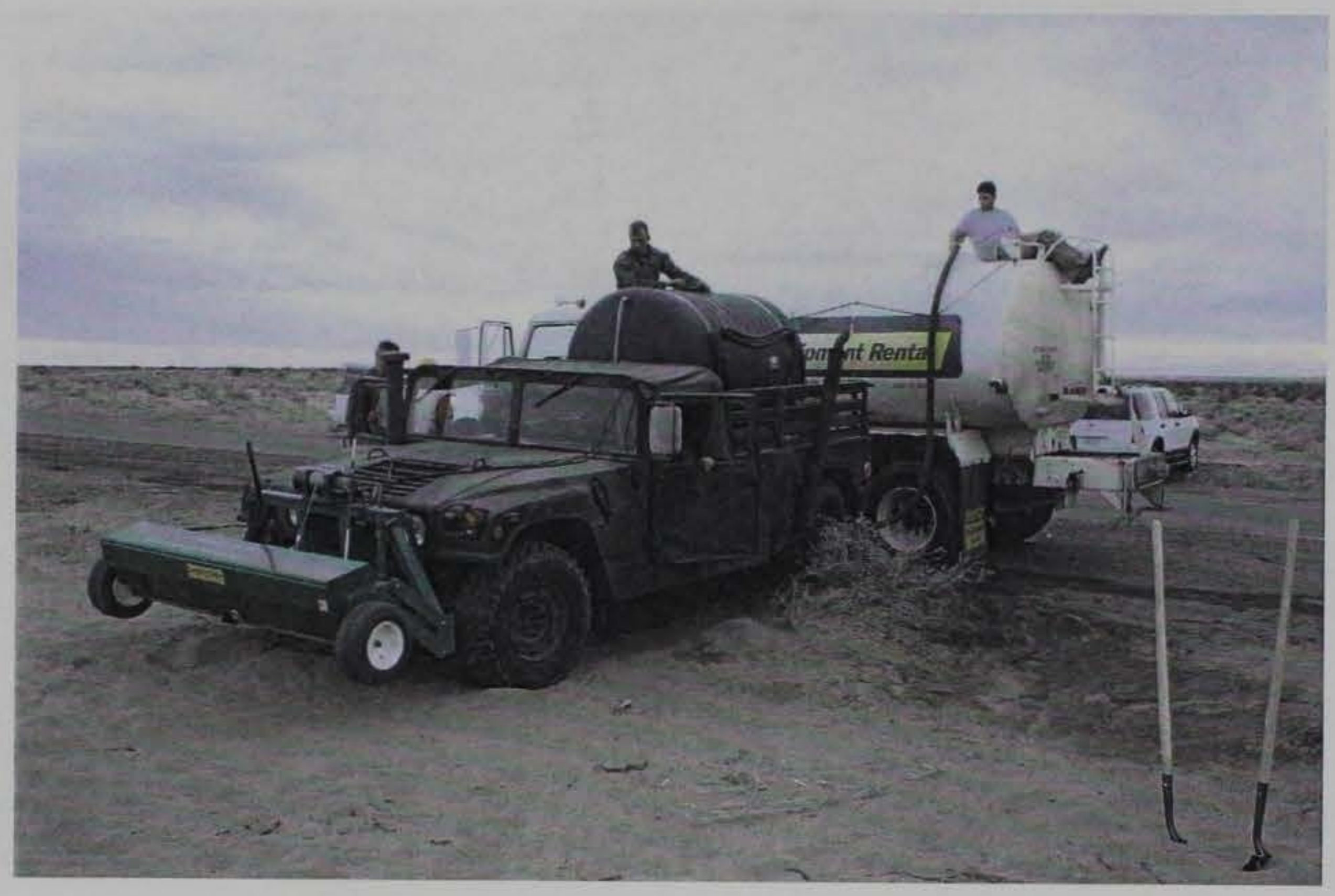

Photo 25. Refilling DAV tank from commercial water truck

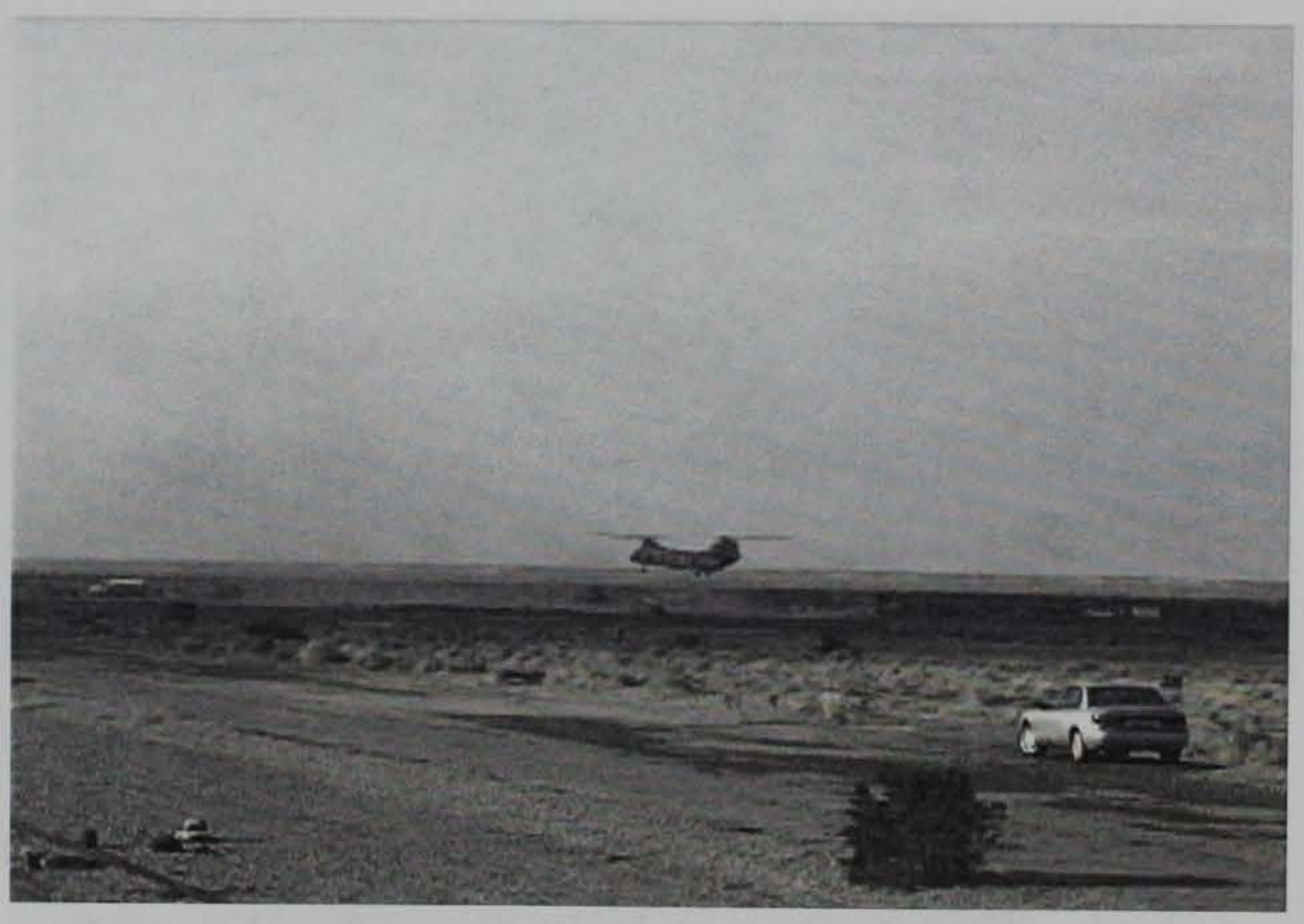

Photo 26. Initial CH-46 operations on Helipad 10 (NRL A) on 21 January 2004 


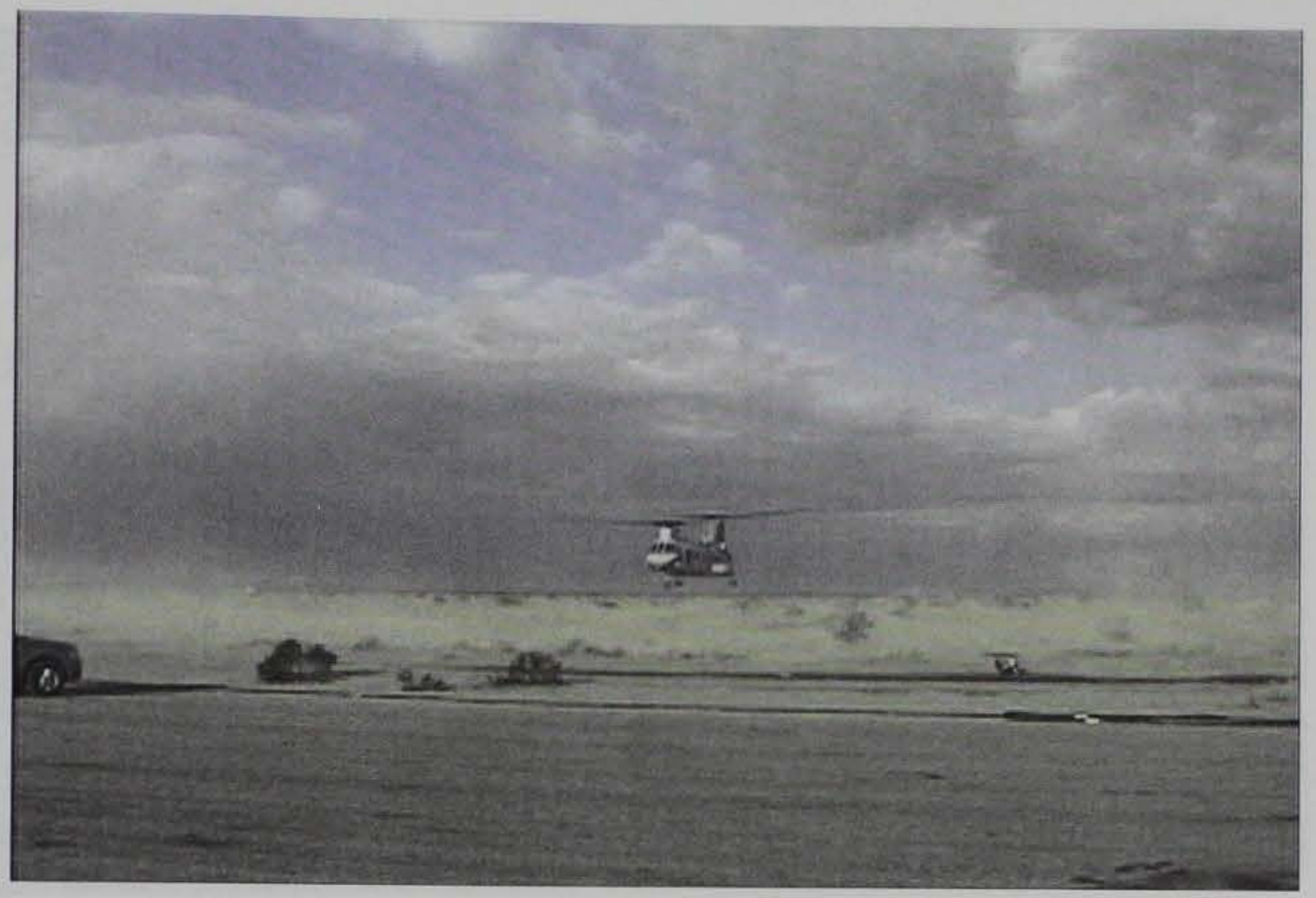

Photo 27. Initial CH-46 operations on Helipad 5 (Soiltac A) on 21 January 2004

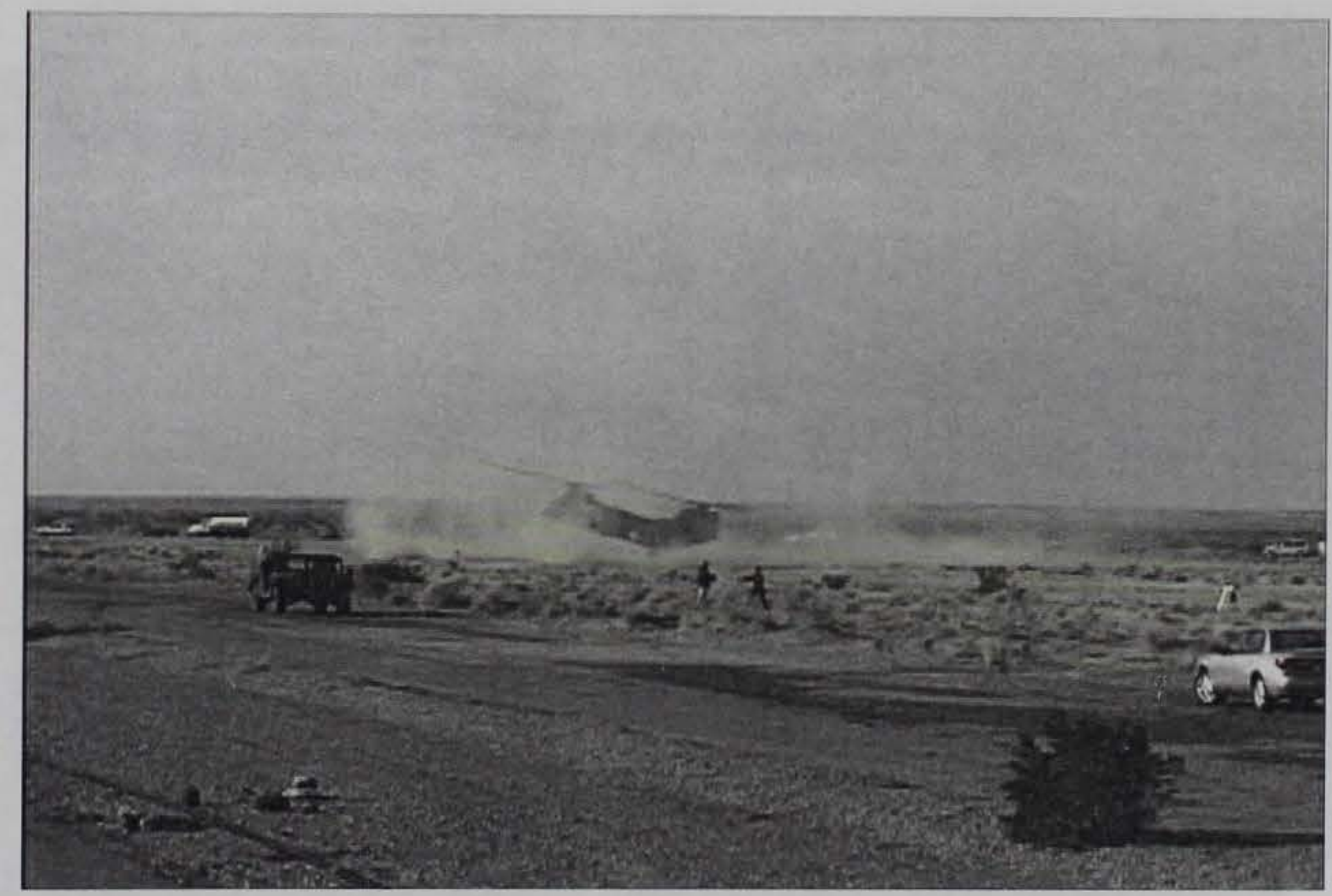

Photo 28. Initial $\mathrm{CH}-46$ operations on Helipad 4 (Envirotac II A) on 21 January 2004 


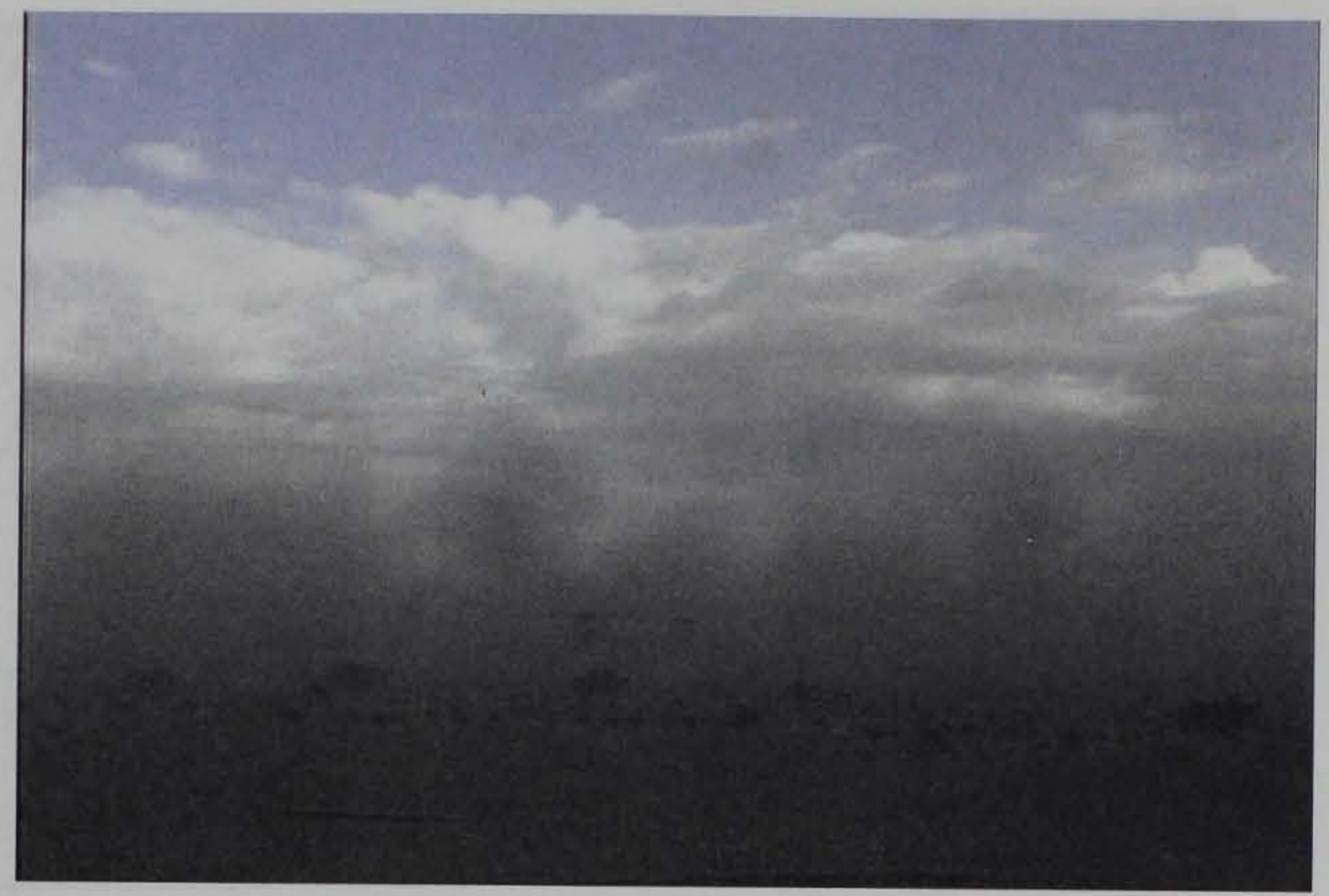

Photo 29. Initial $\mathrm{CH}-46$ operations on the untreated Helipad 18 on 21 January 2004

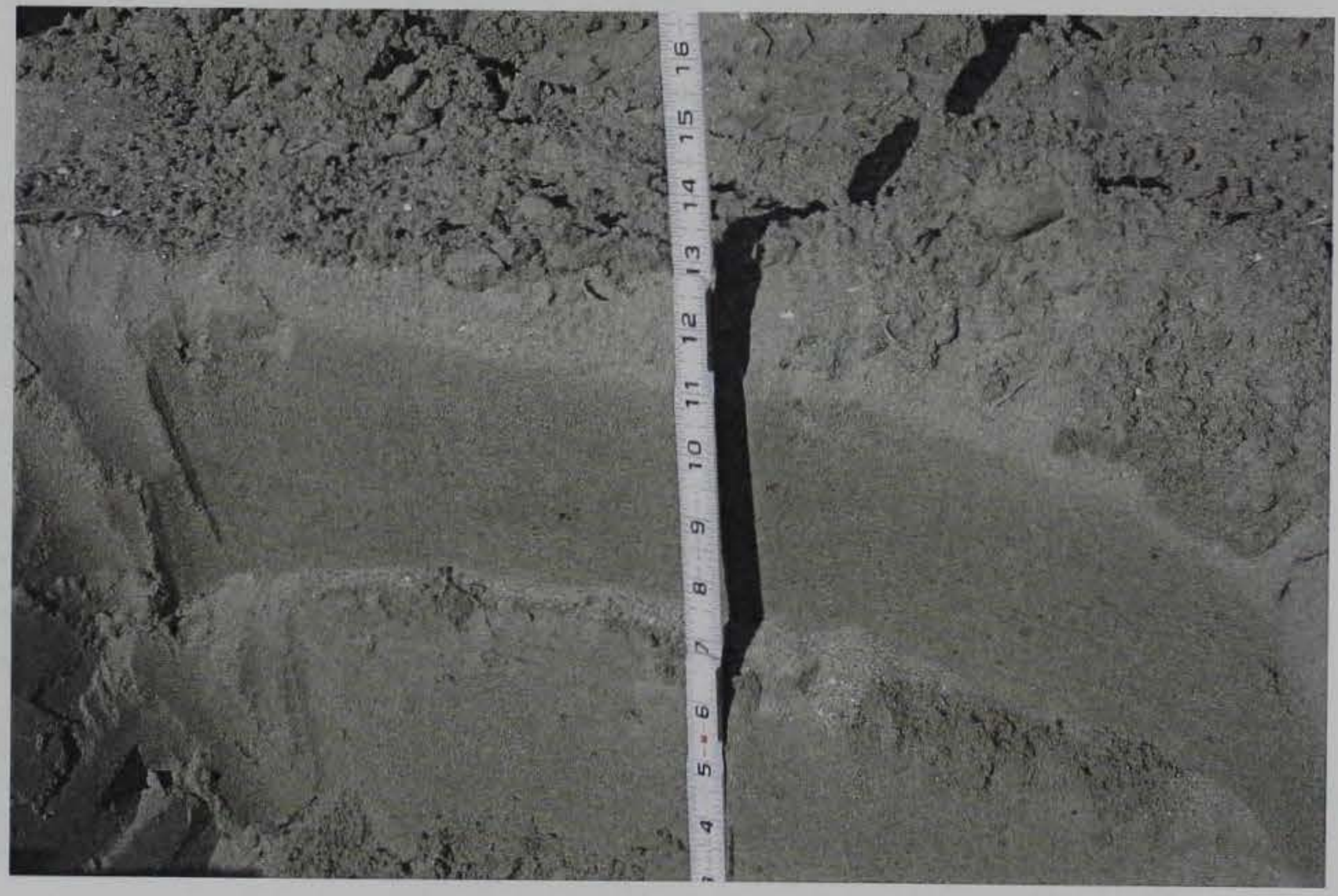

Photo 30. Depth to moisture in untreated buffer zone 


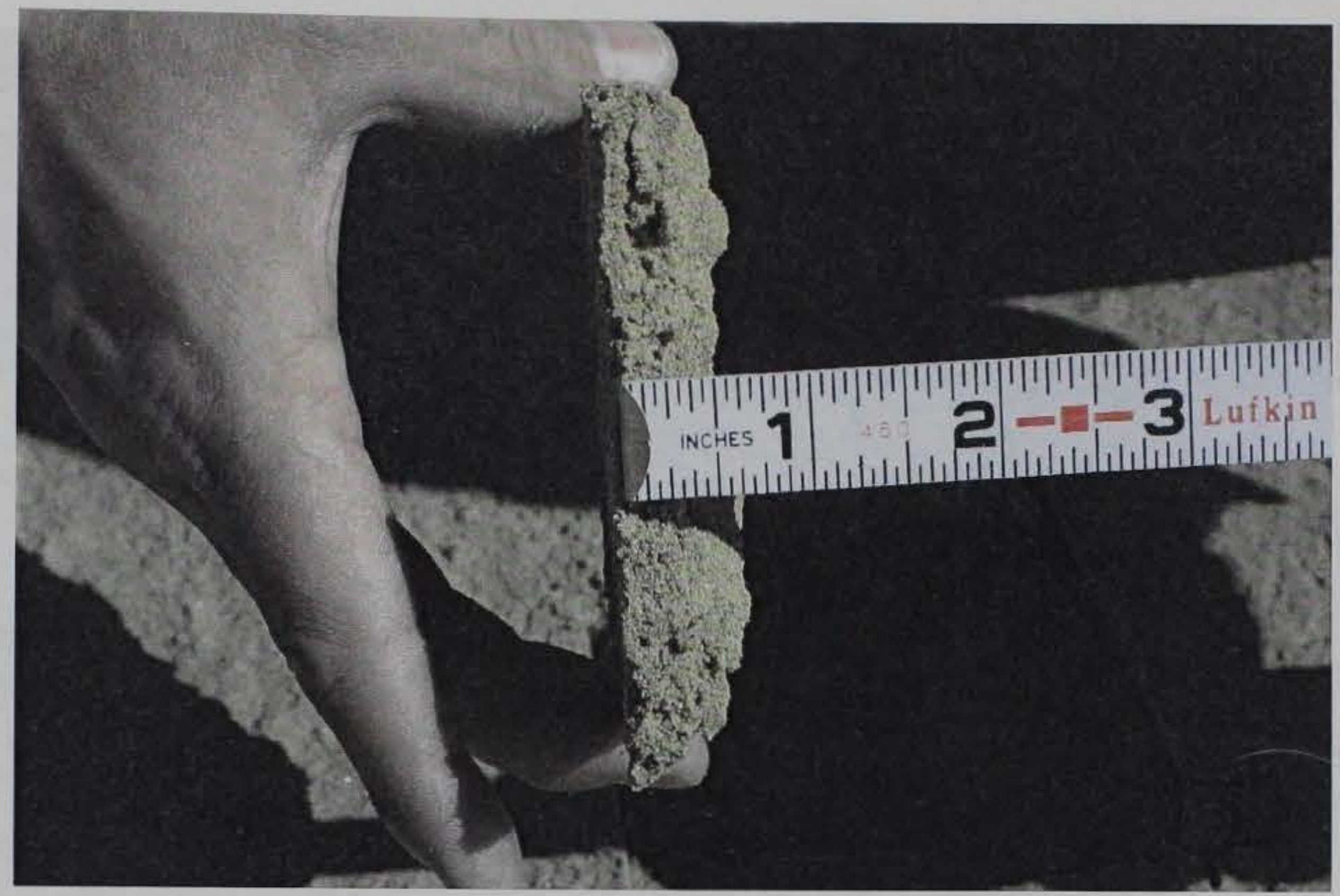

Photo 31. Tri-PAM crust thickness on Helipad 3

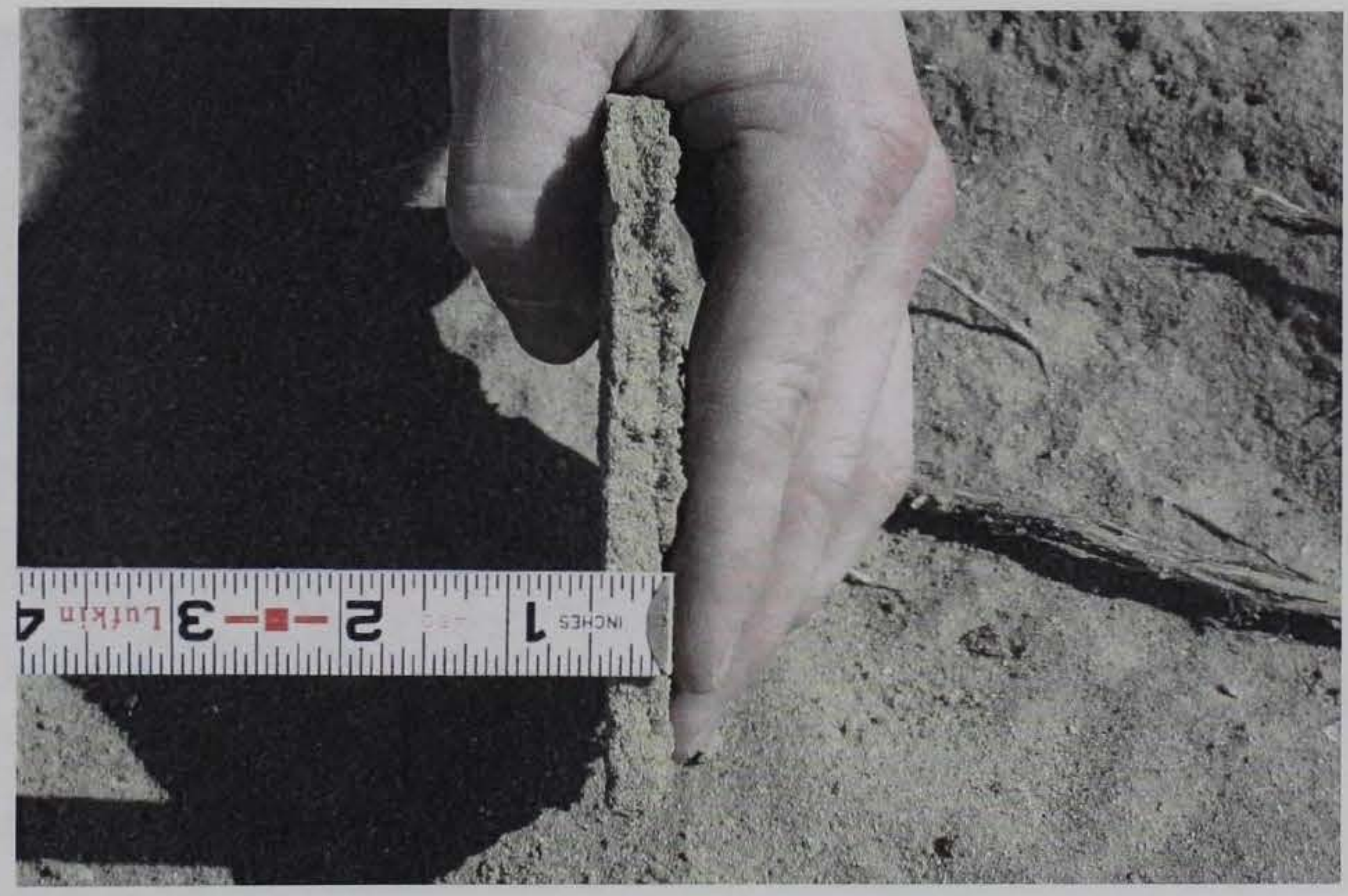

Photo 32. Soiltac B crust thickness on Helipad 6 


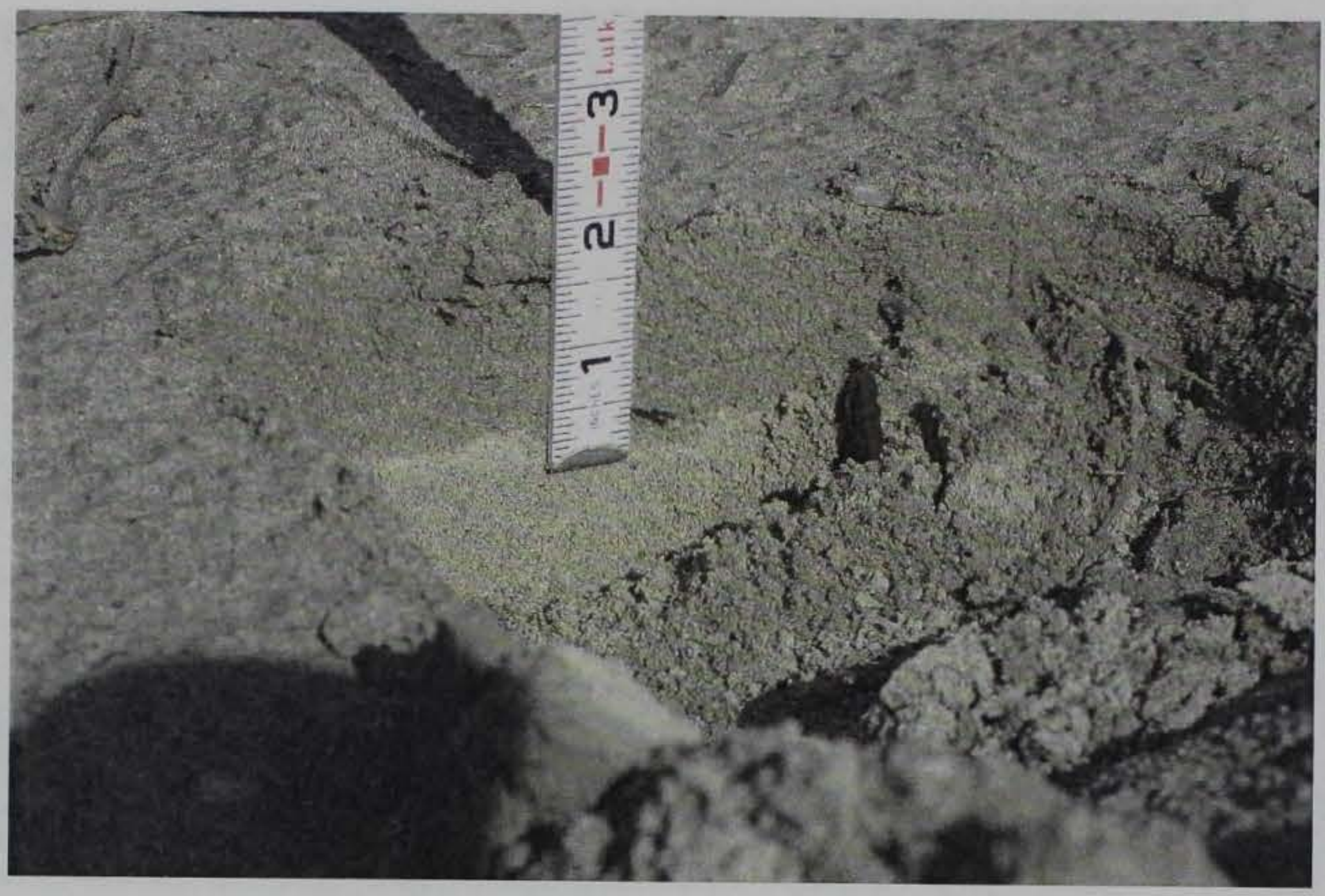

Photo 33. EnviroKleen penetration depth on Helipad 15

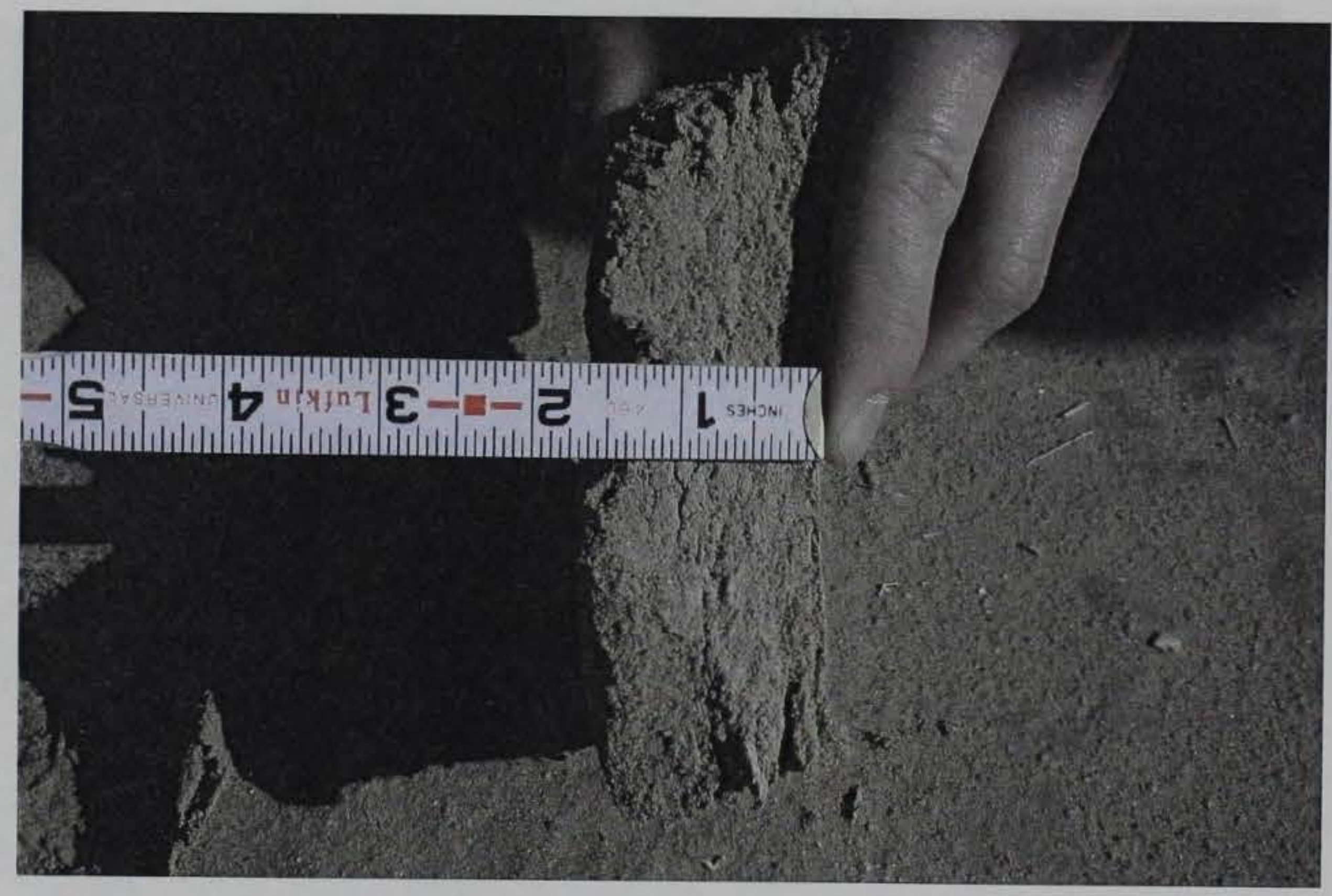

Photo 34. Soiltac A crust thickness on Helipad 5 


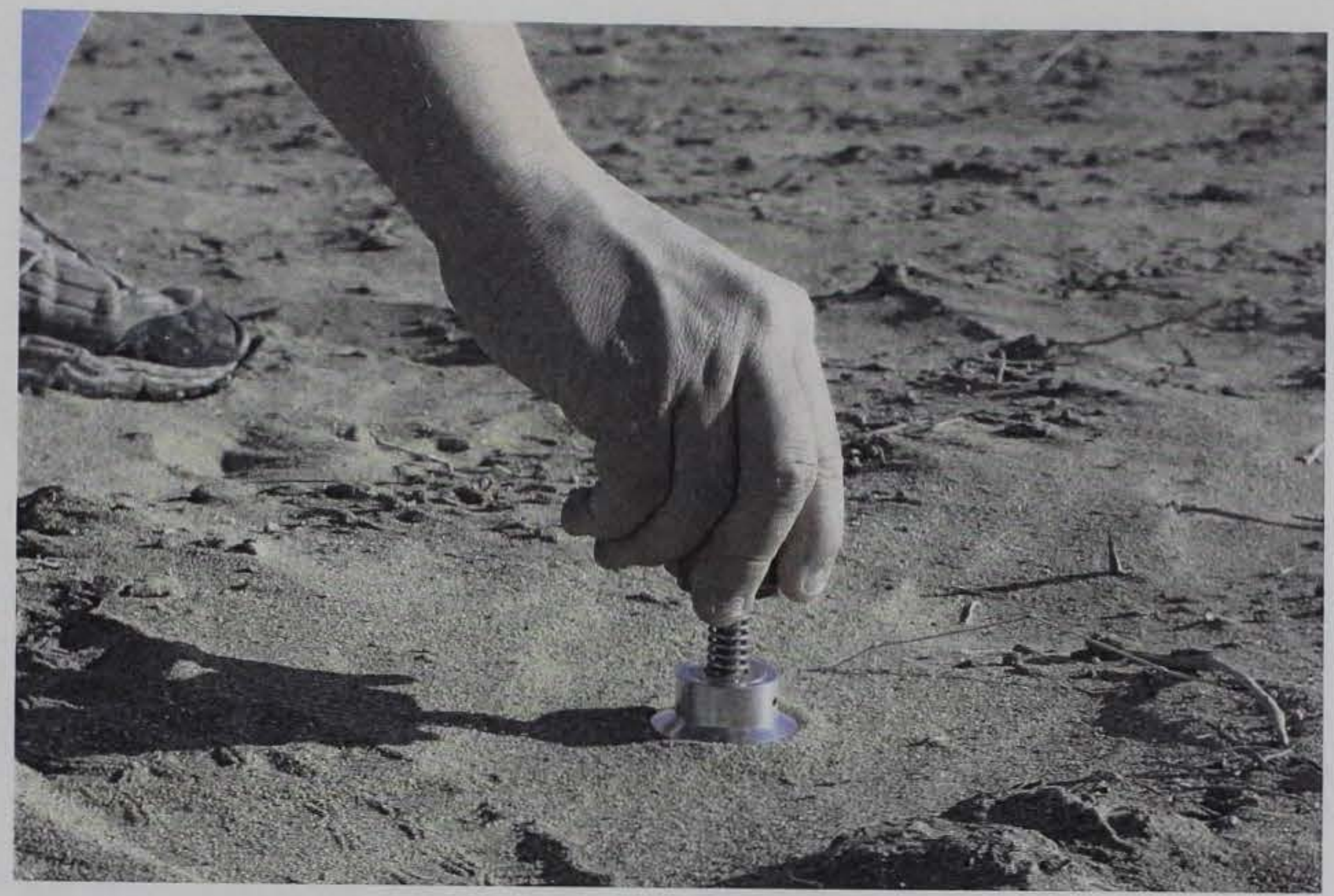

Photo 35. Torvane surface shear strength measurement

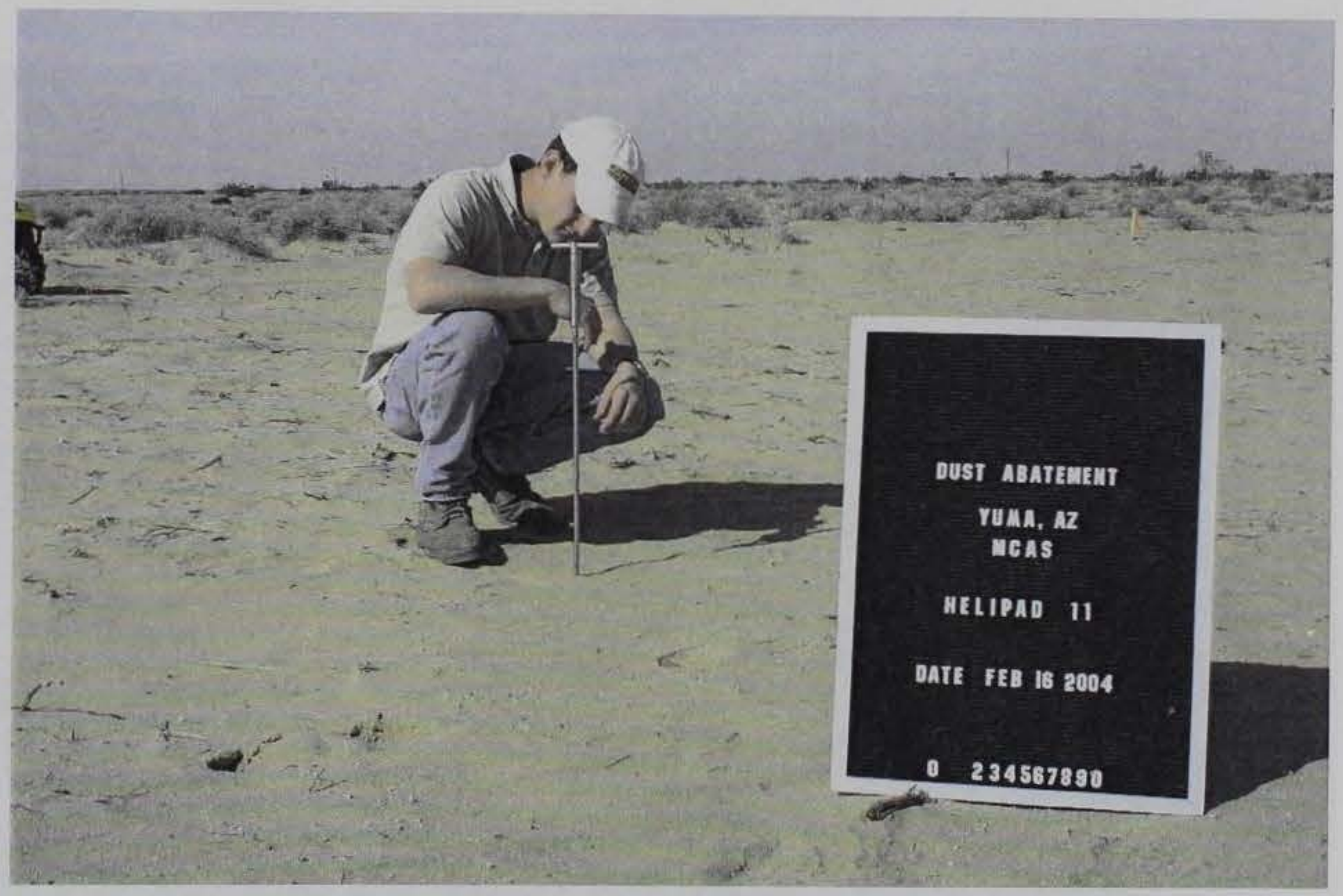

Photo 36. Geonor vane shear measurement on Helipad 11 (NRL B) 


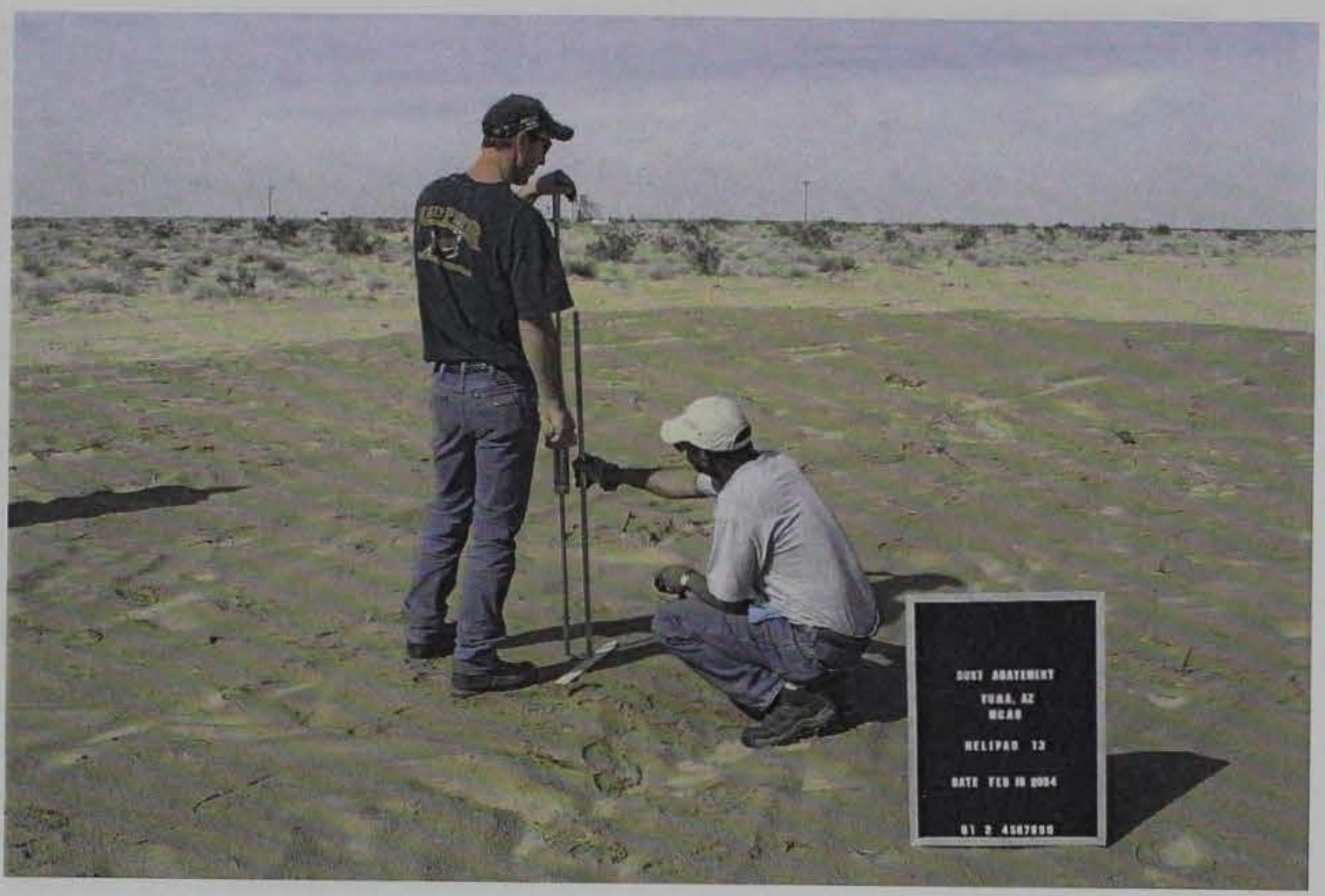

Photo 37. Dynamic cone penetrometer (DCP) testing on Helipad 13 (EnviroKleen B)

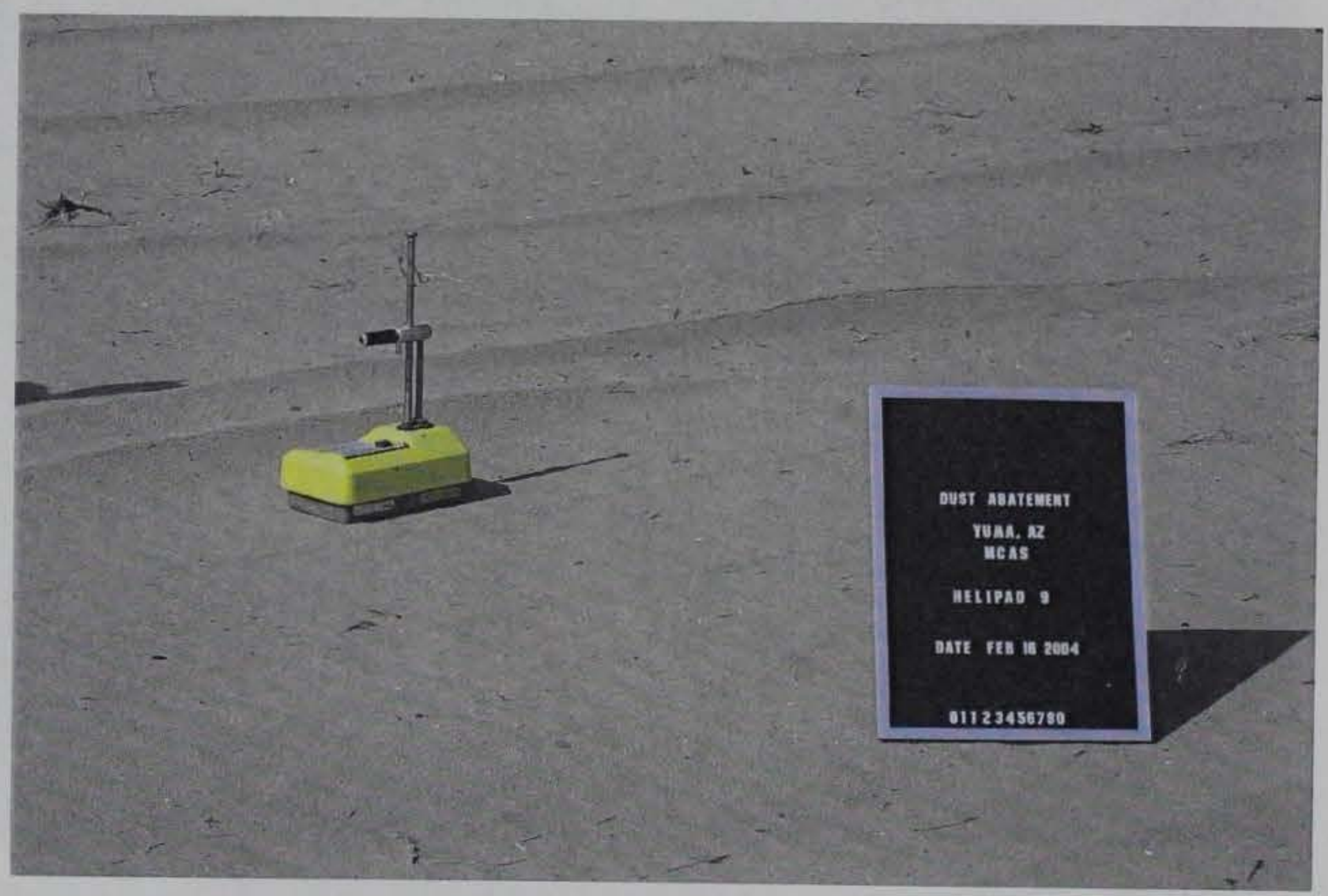

Photo 38. Nuclear gage measurement of moisture and density on Helipad 9 (LDC) 


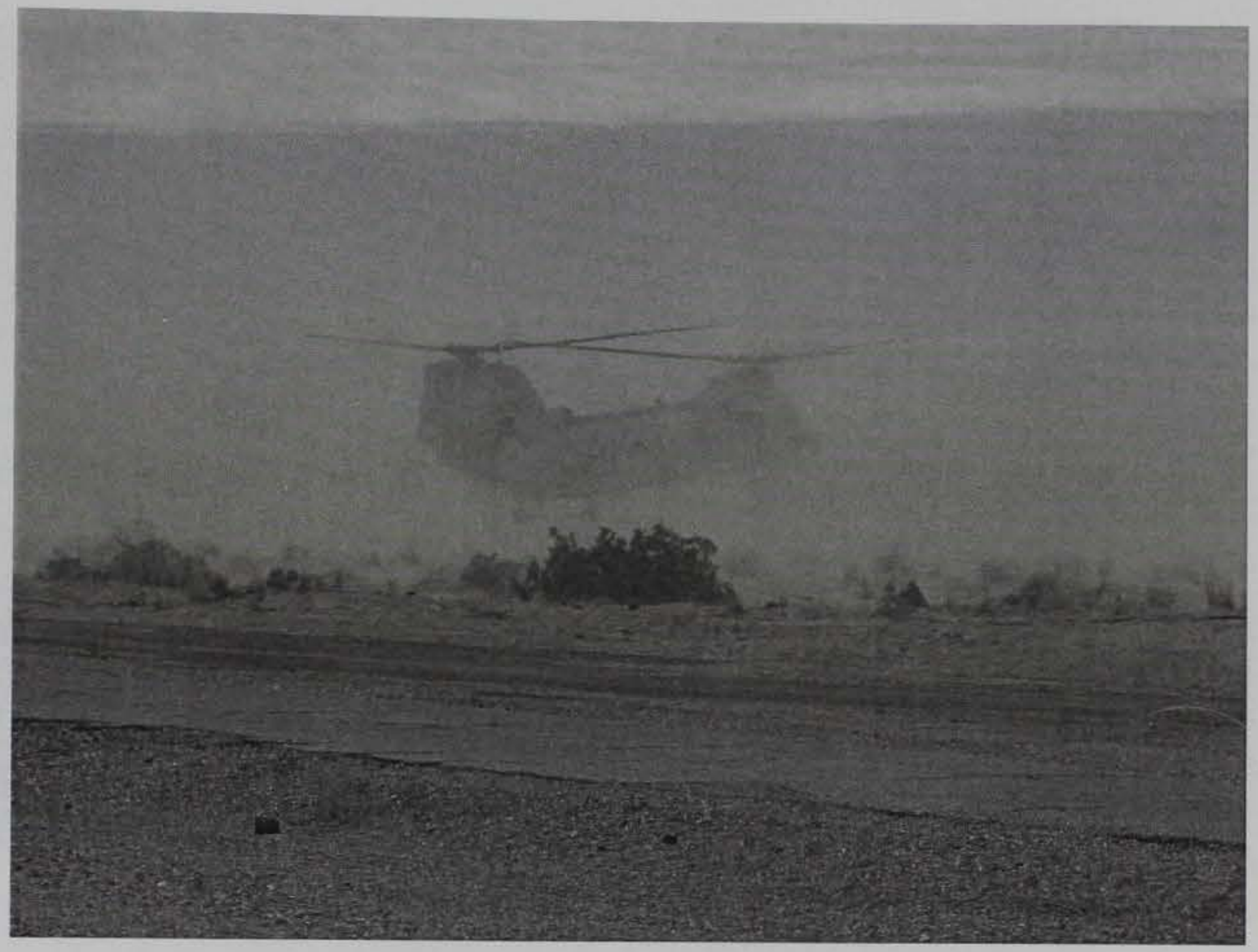

Photo 39. $\mathrm{CH}-46$ operations on Helipad 18 (untreated control) on 18 February 2004

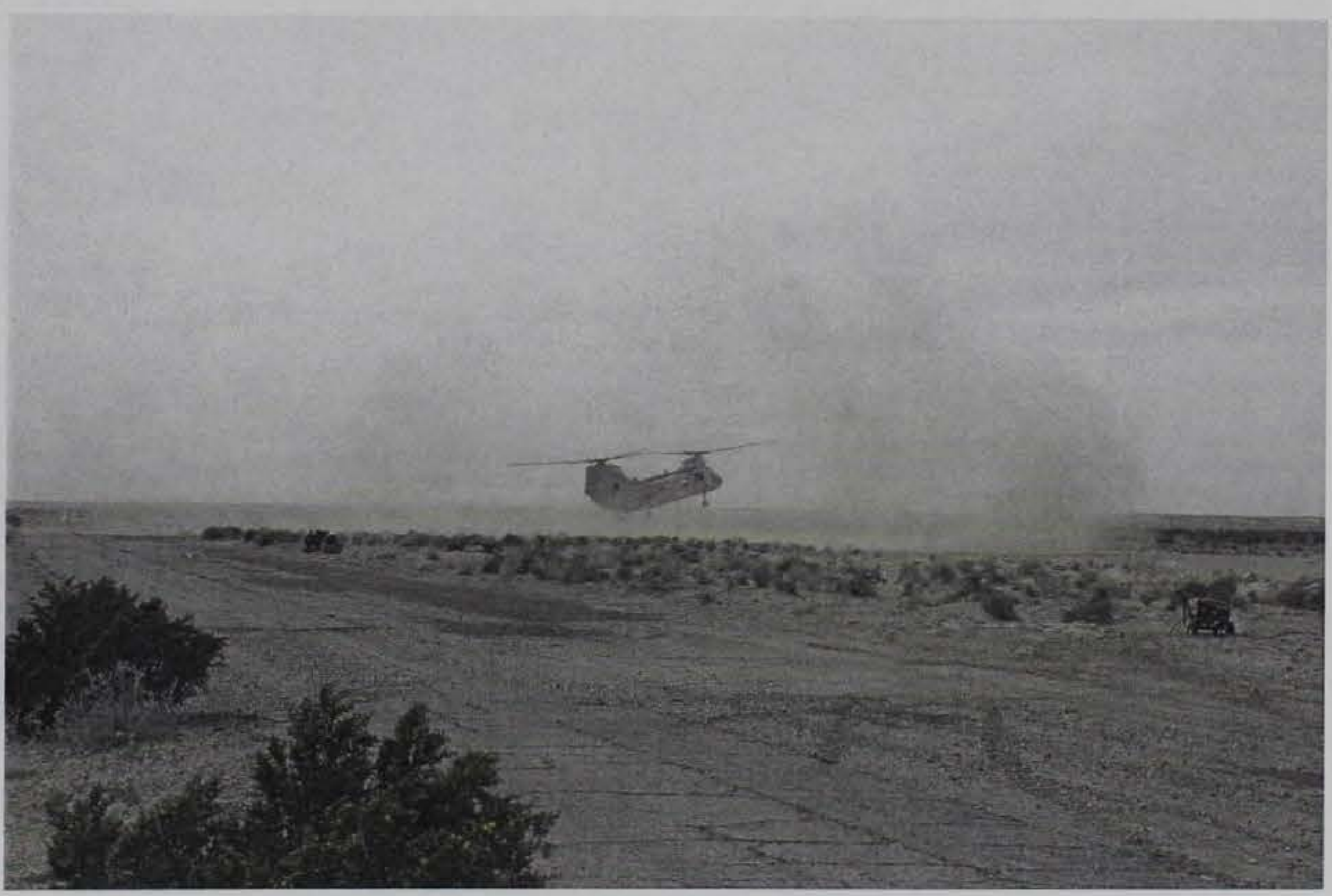

Photo 40. $\mathrm{CH}-46$ operations on Helipad 1 (PolyPlus 100) on 18 February 2004 


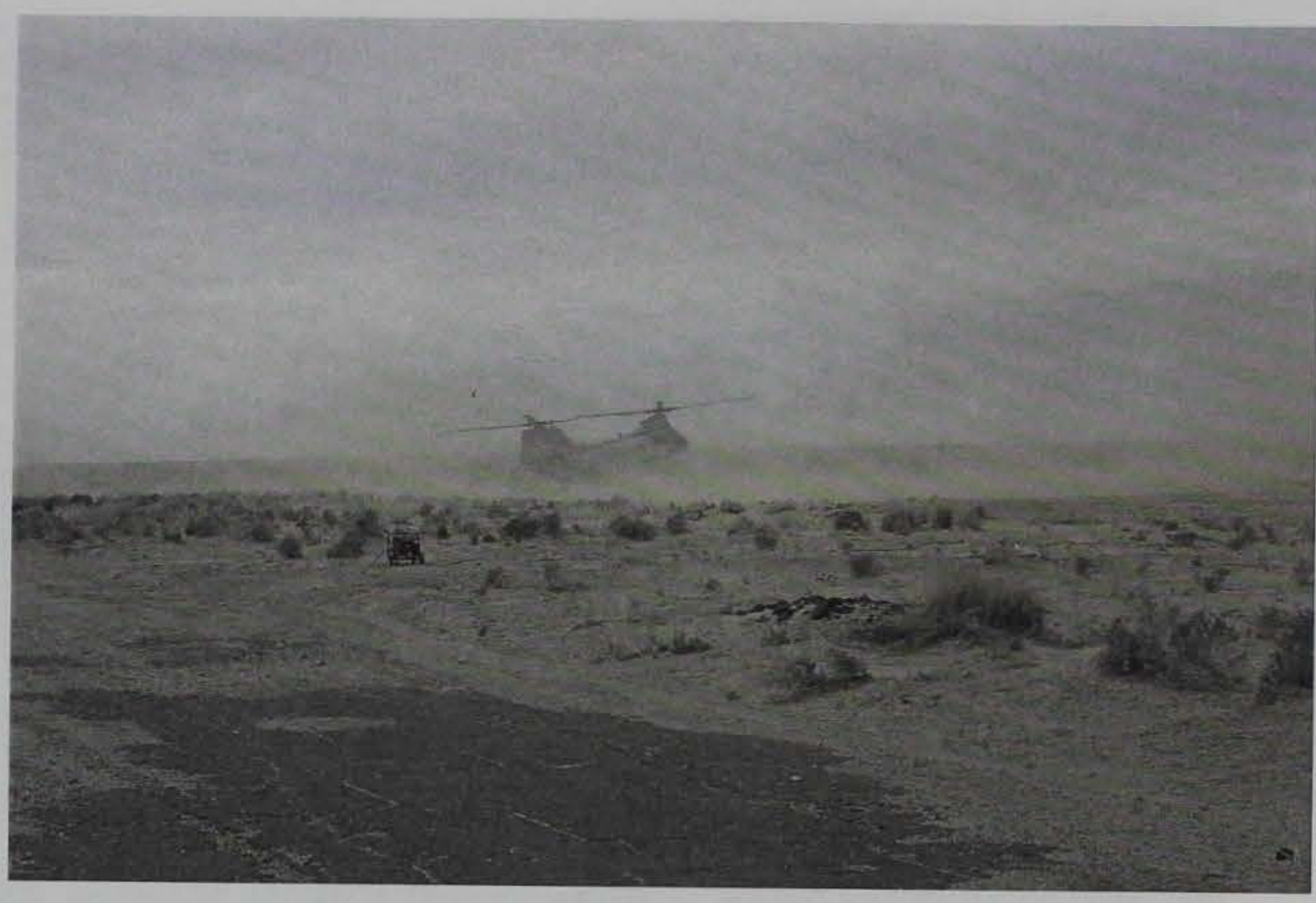

Photo 41. $\mathrm{CH}-46$ operations on Helipad 2 (PolyPlus) on 18 February 2004

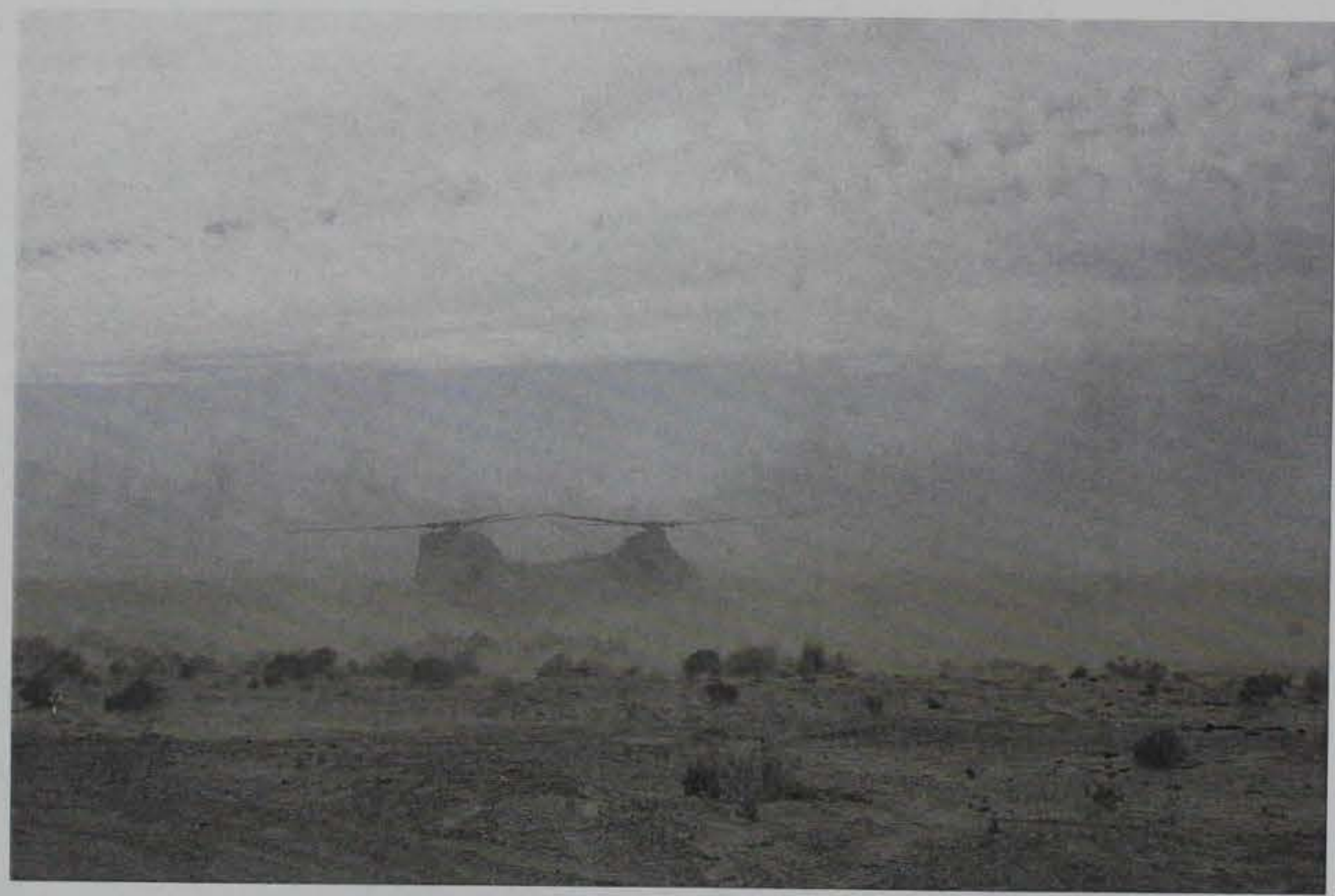

Photo 42. $\mathrm{CH}-46$ operations on Helipad 3 (Tri-PAM) on 18 February 2004 


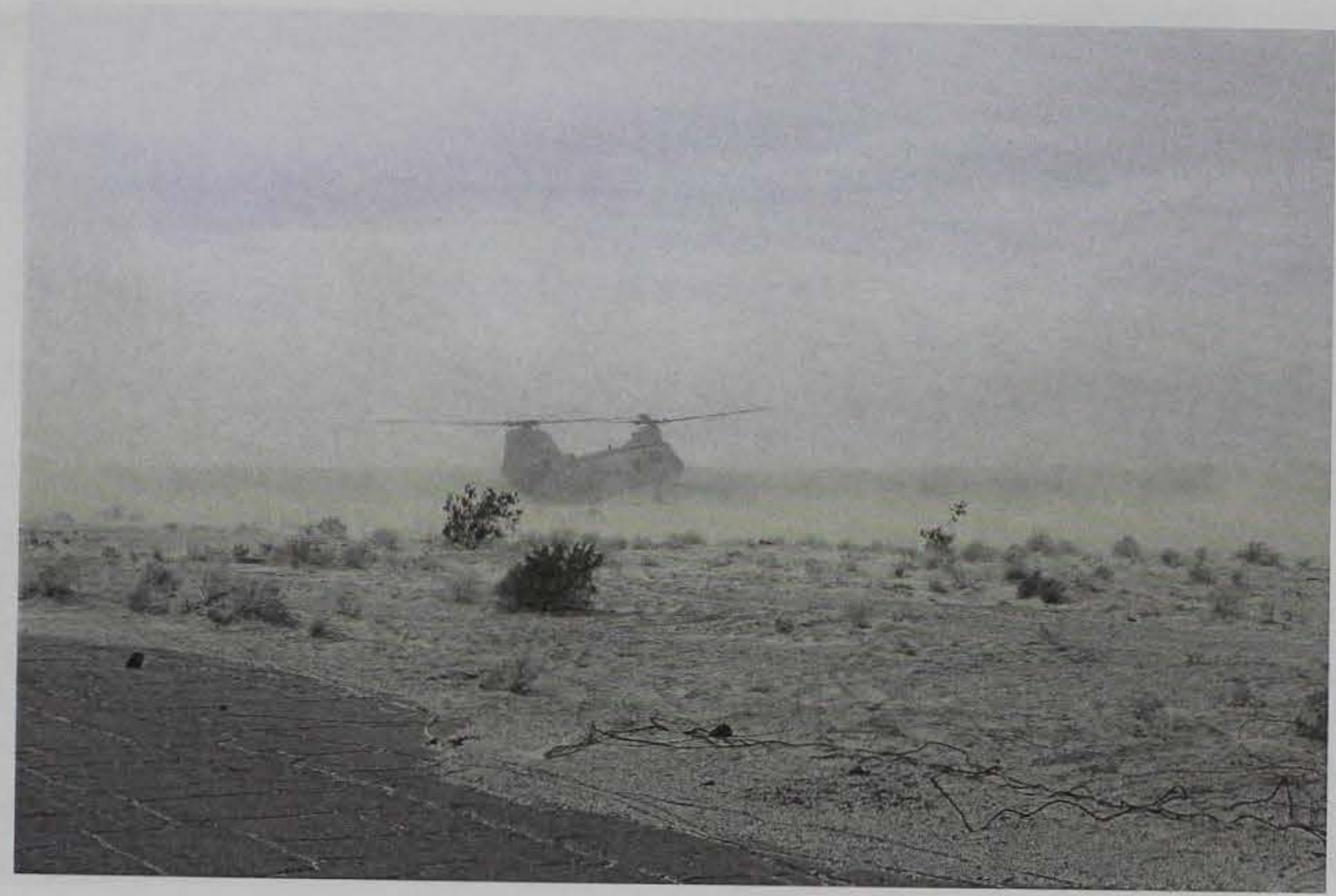

Photo 43. CH-46 operations on Helipad 4 (Envirotac II A) on 18 February 2004

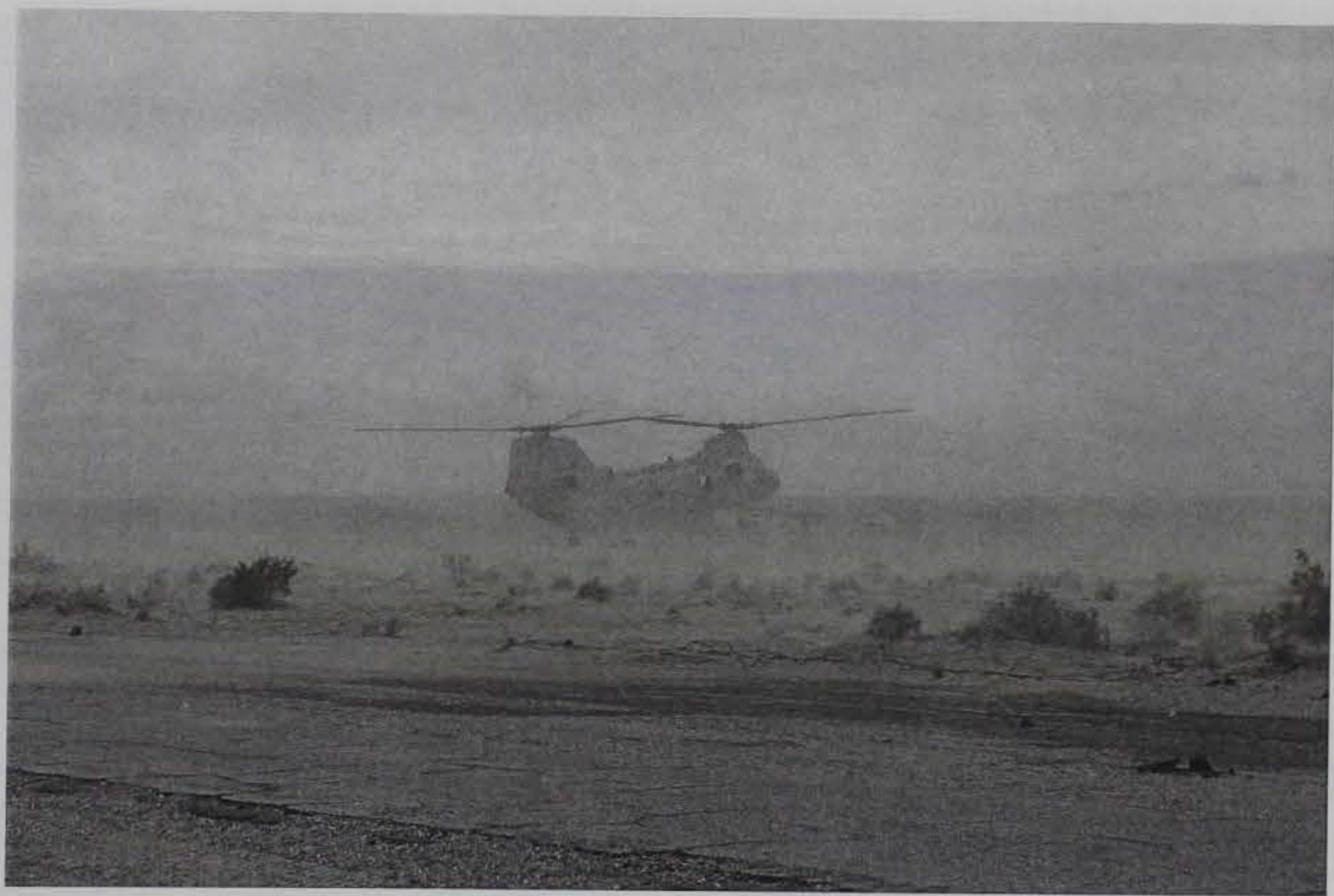

Photo 44. CH-46 operations on Helipad 5 (Soiltac A) on 18 February 2004 


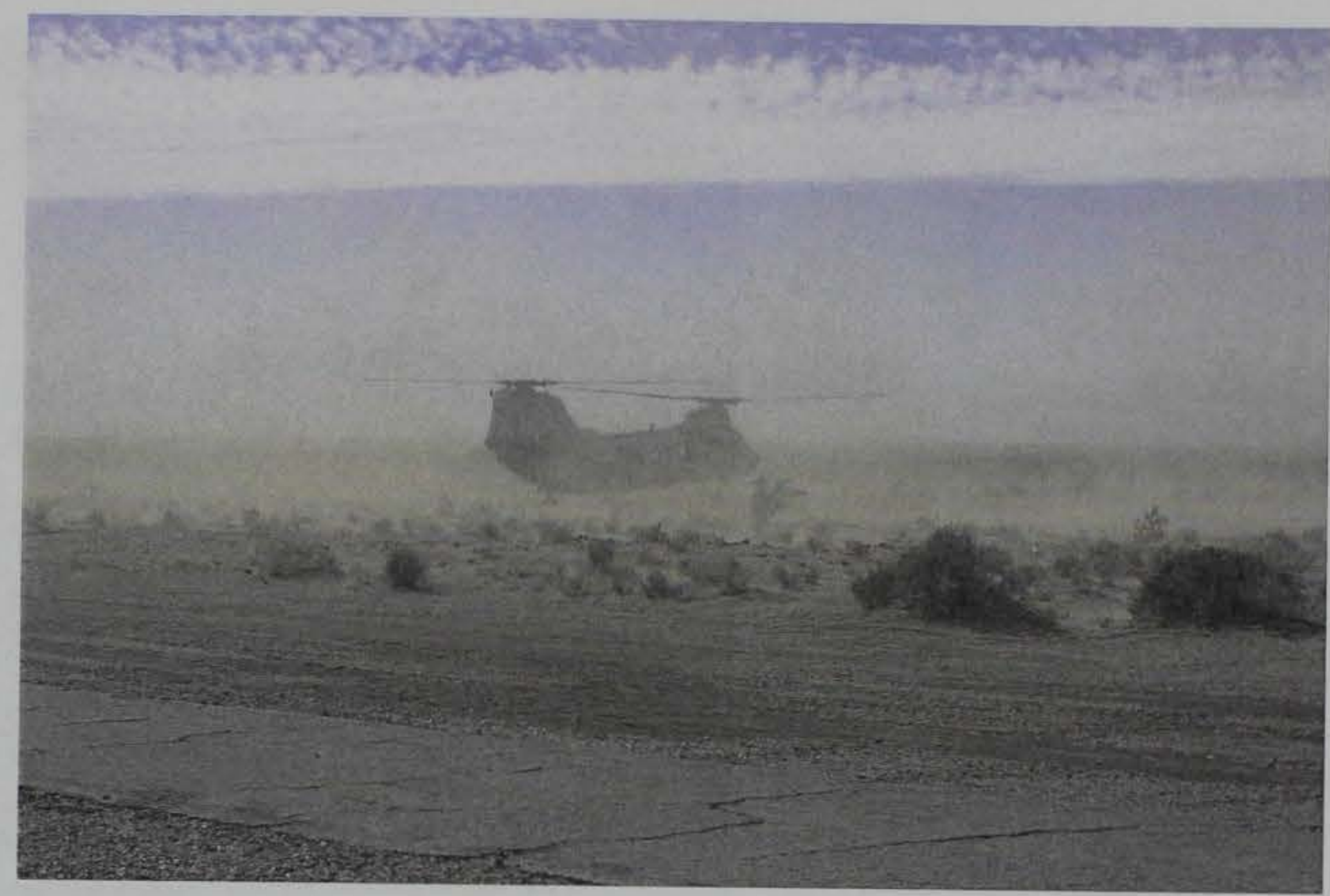

Photo 45. CH-46 operations on Helipad 6 (Soiltac B) on 18 February 2004

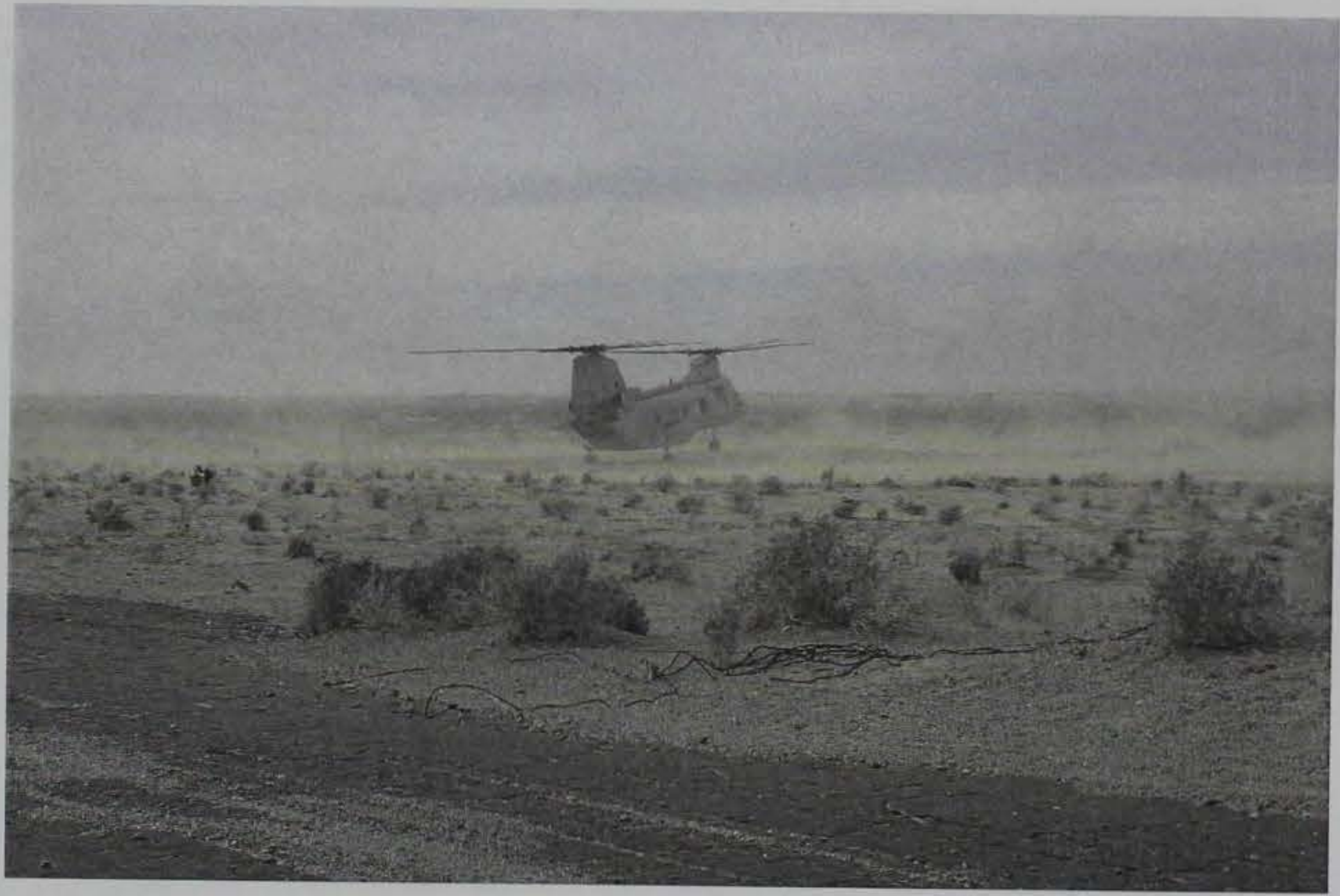

Photo 46. CH-46 operations on Helipad 7 (Envirotac II B) on 18 February 2004 


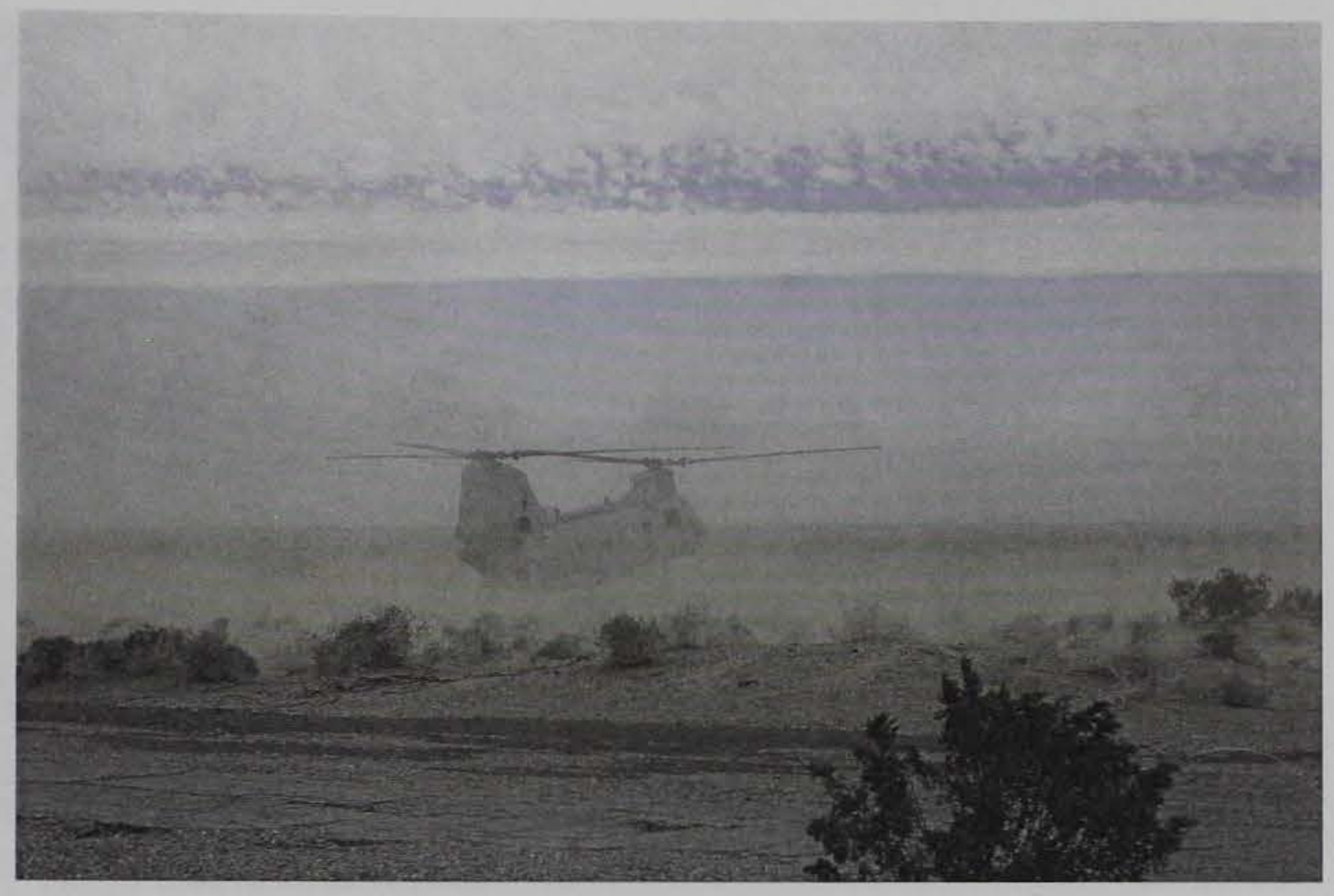

Photo 47. CH-46 operations on Helipad 8 (ECO 110) on 18 February 2004

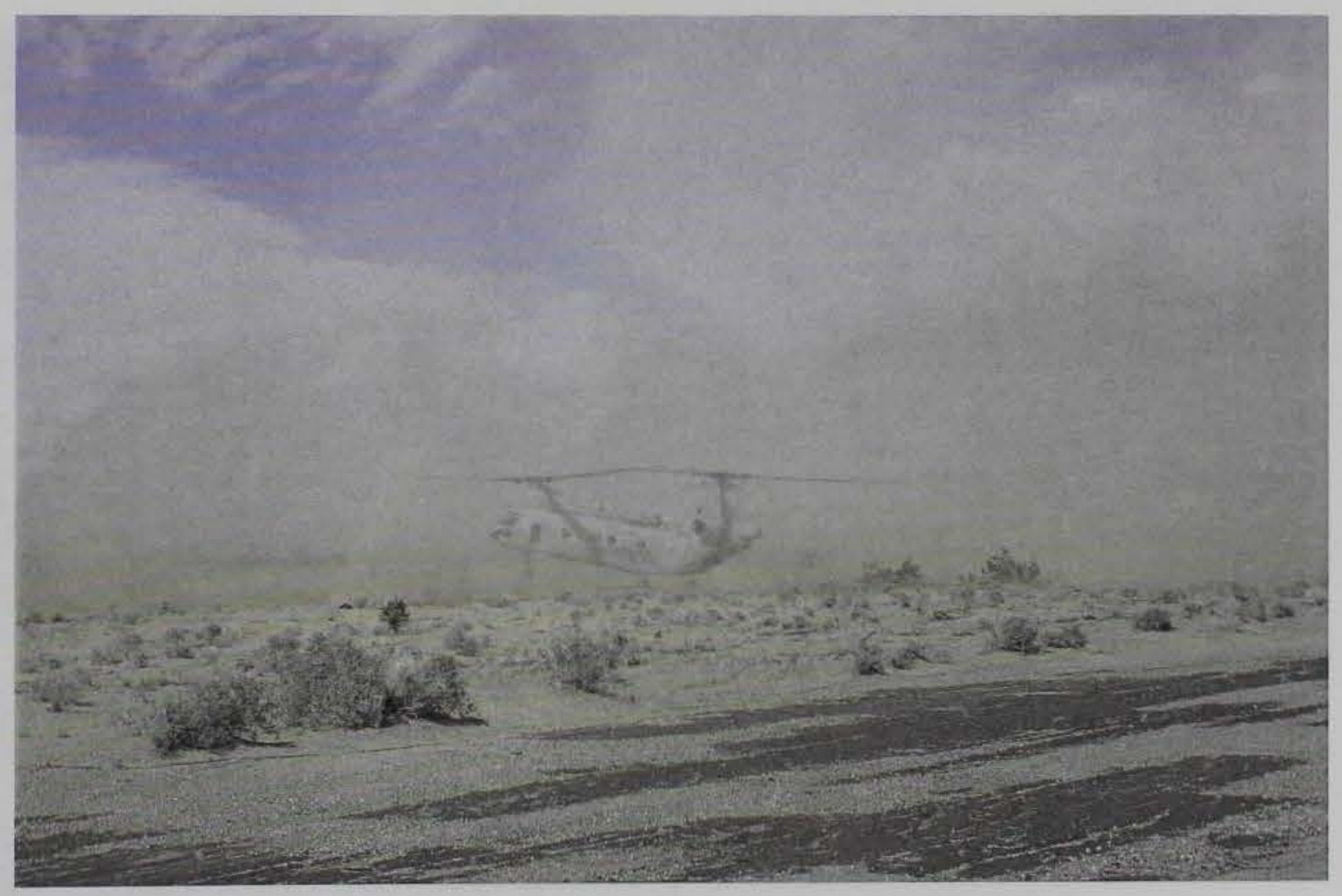

Photo 48. CH-46 operations on Helipad 9 (LDC) on 18 February 2004 


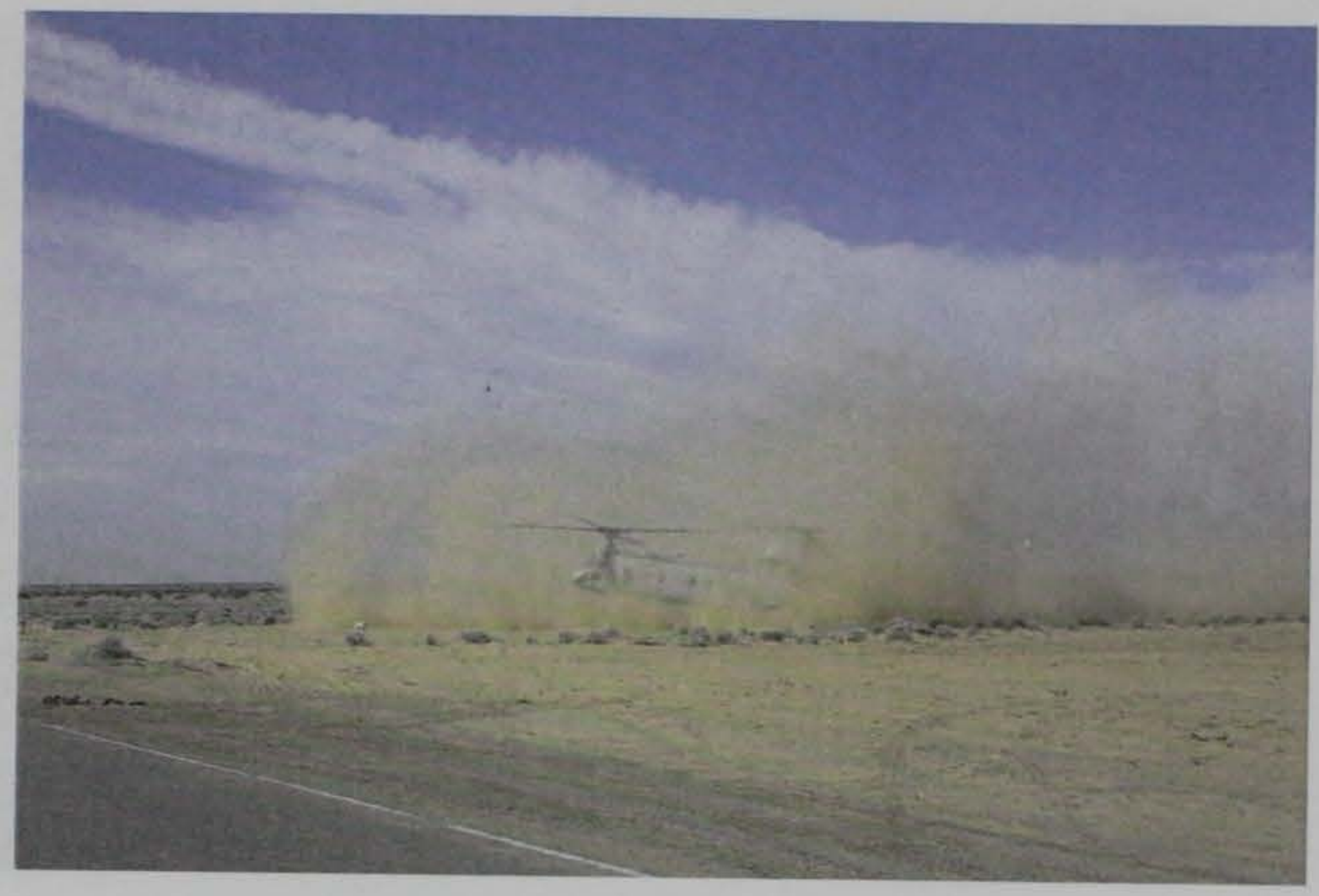

Photo 49. $\mathrm{CH}-46$ operations on Helipad 10 (NRL A) on 18 February 2004

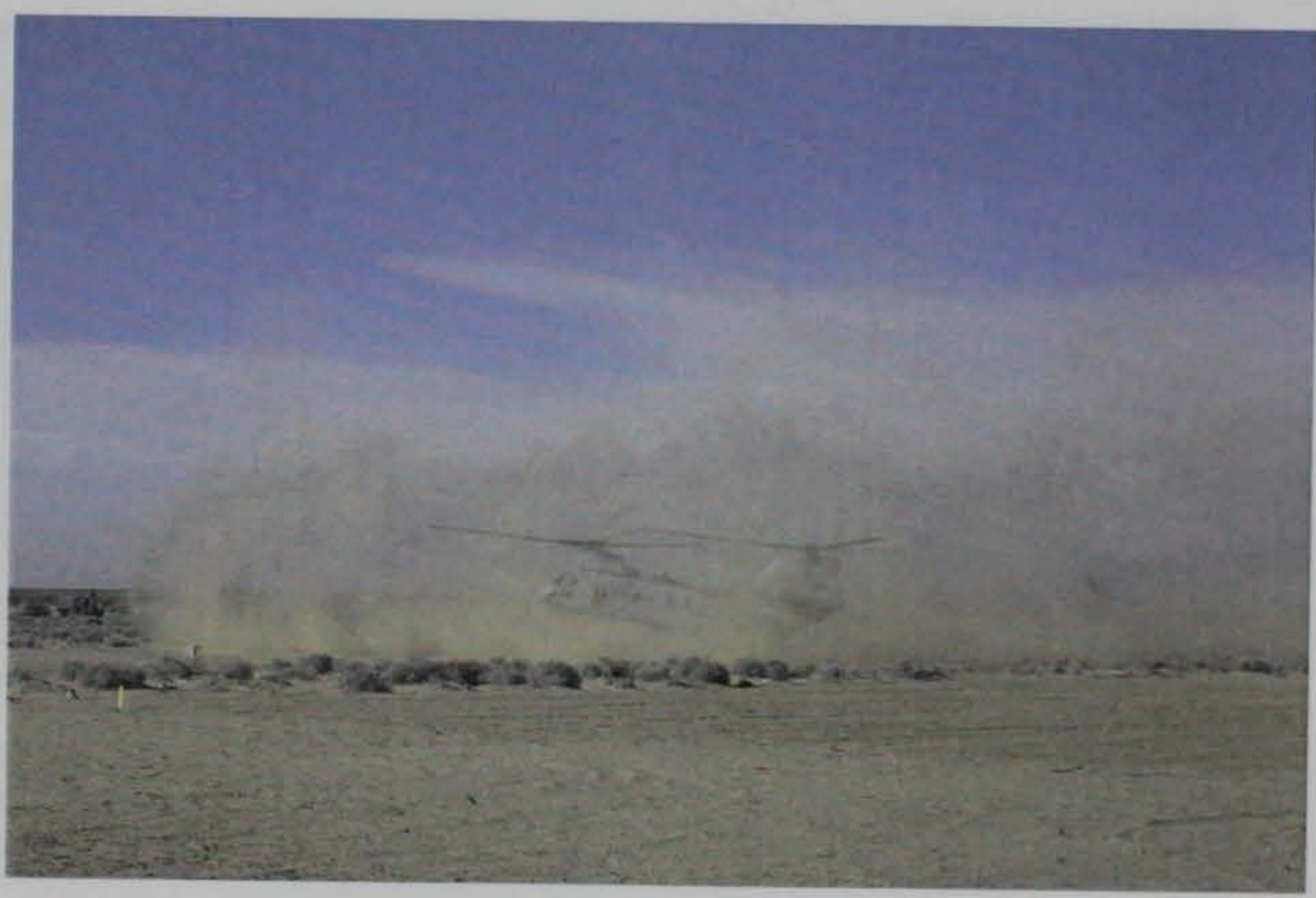

Photo 50. CH-46 operations on Helipad 11 (NRL B) on 18 February 2004 


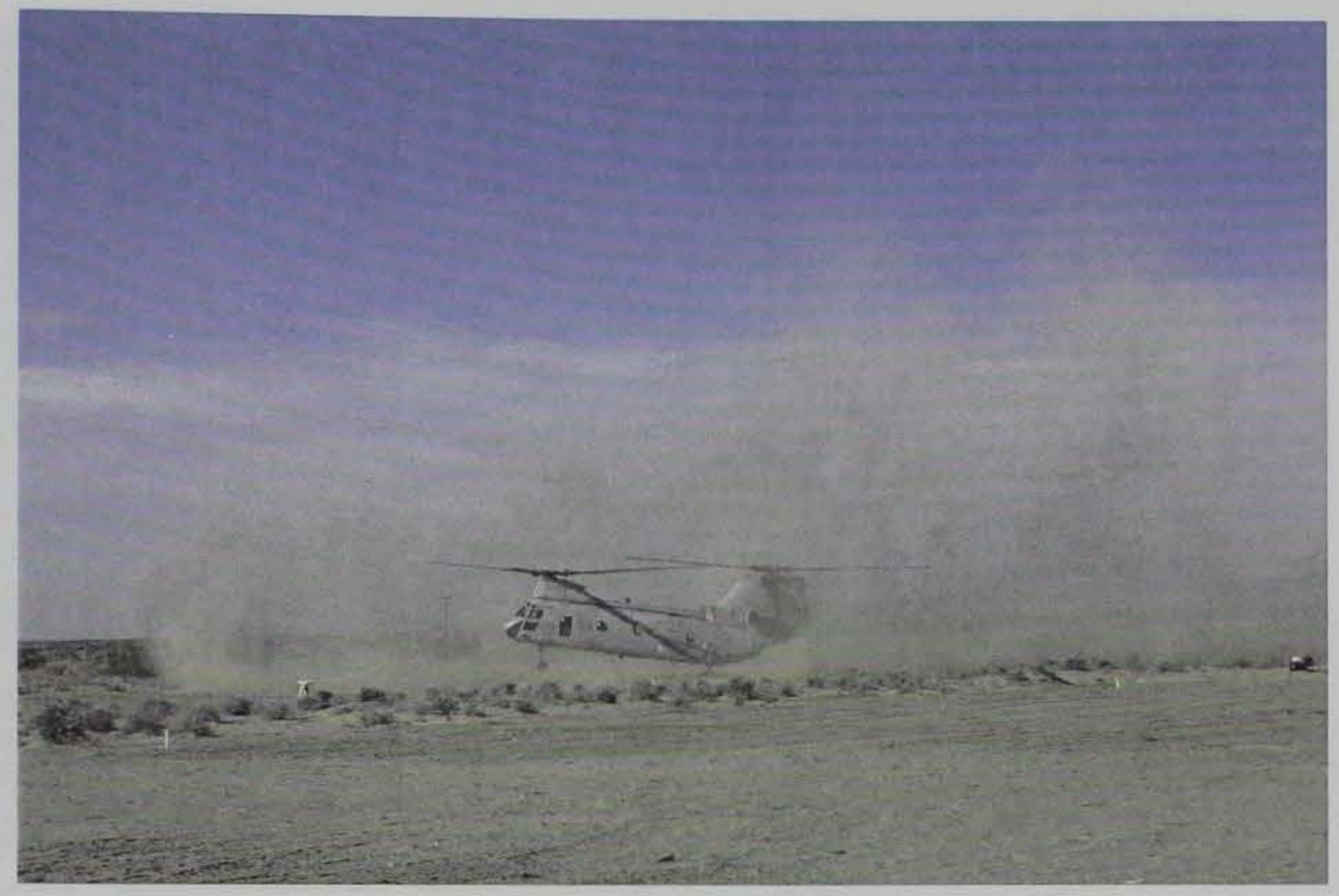

Photo 51. CH-46 operations on Helipad 12 (Road Oyl) on 18 February 2004

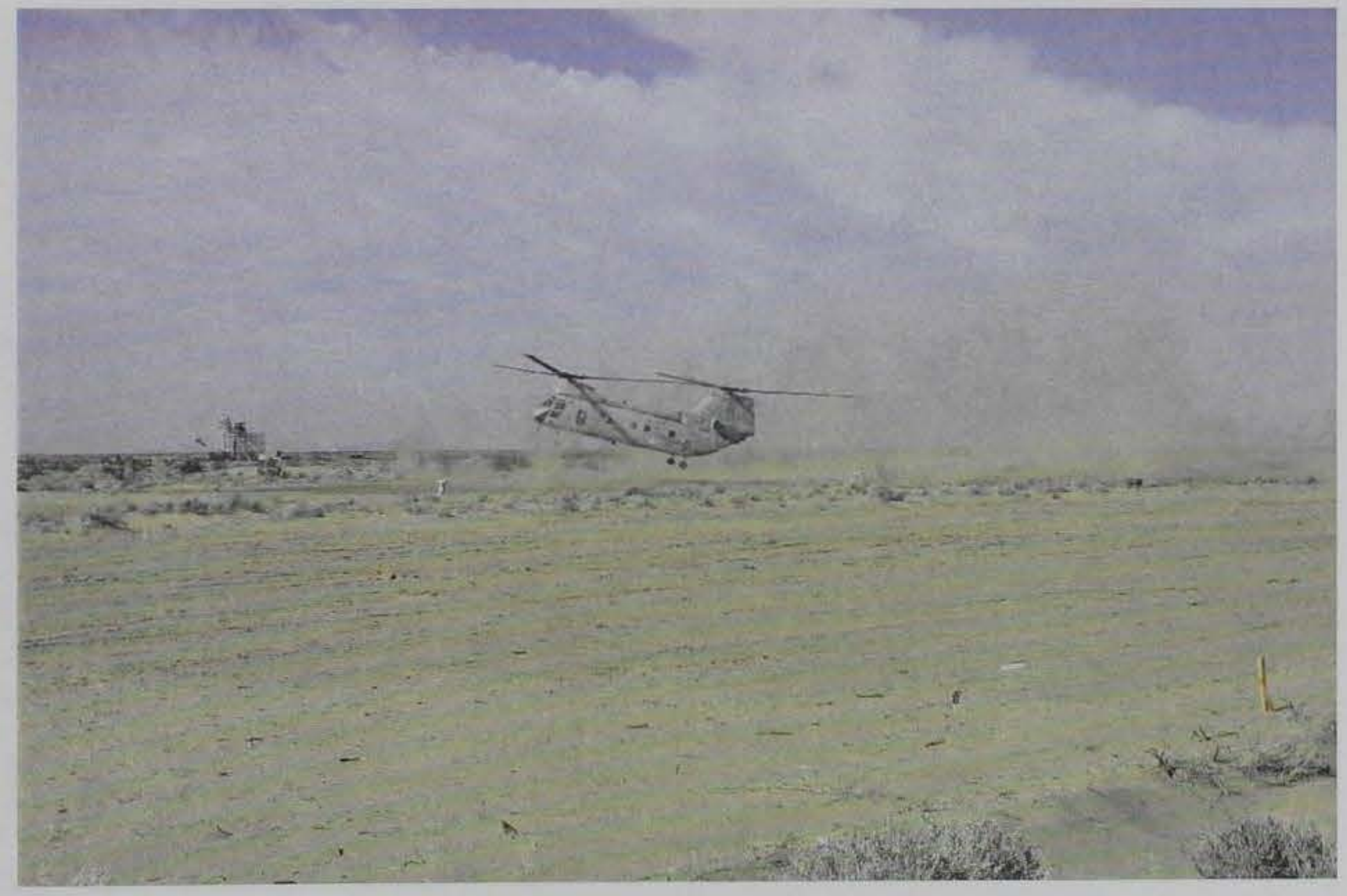

Photo 52. $\mathrm{CH}-46$ operations on Helipad 13 (EnviroKleen B) on 18 February 2004 


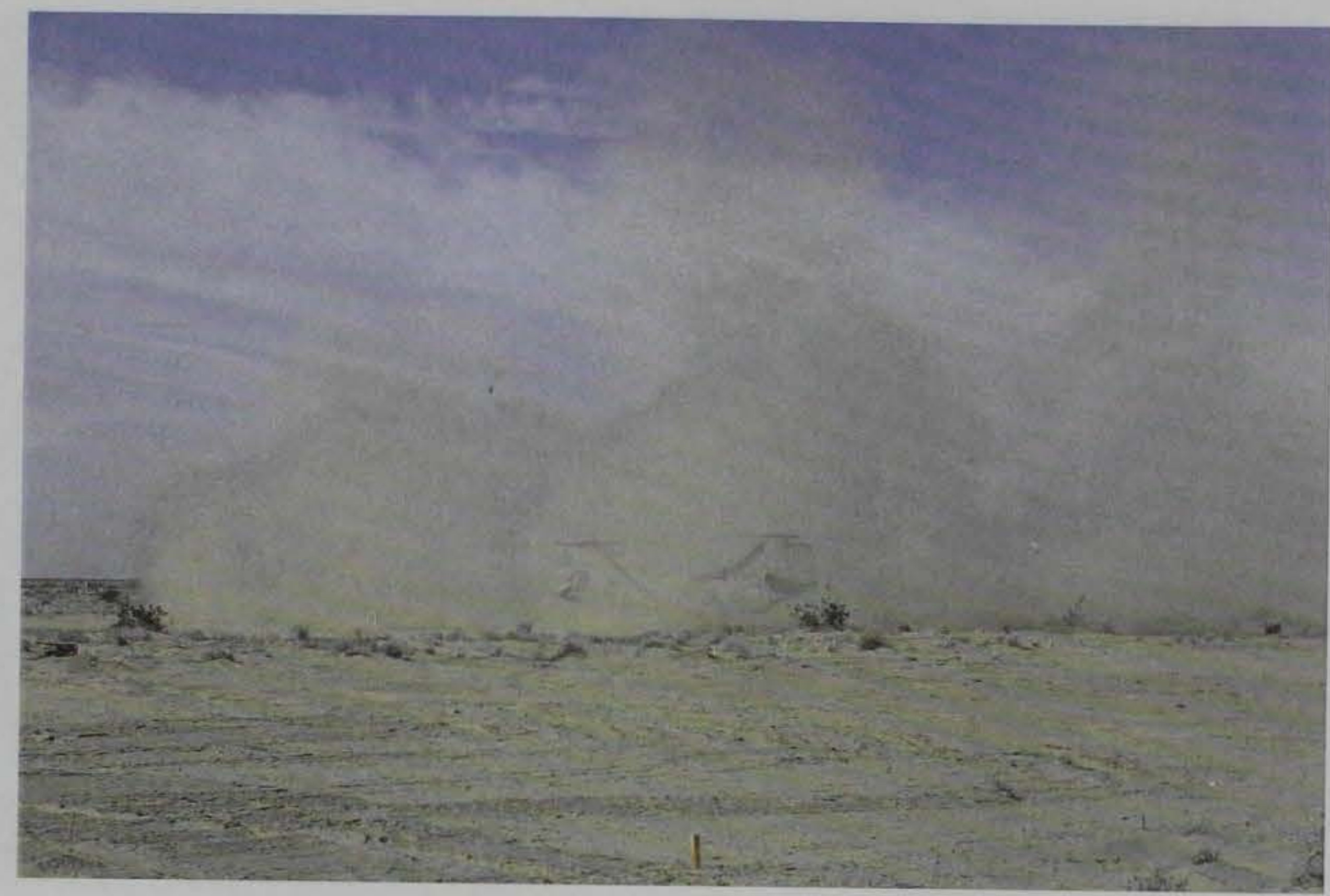

Photo 53. CH-46 operations on Helipad 14 (Dustac A) on 18 February 2004

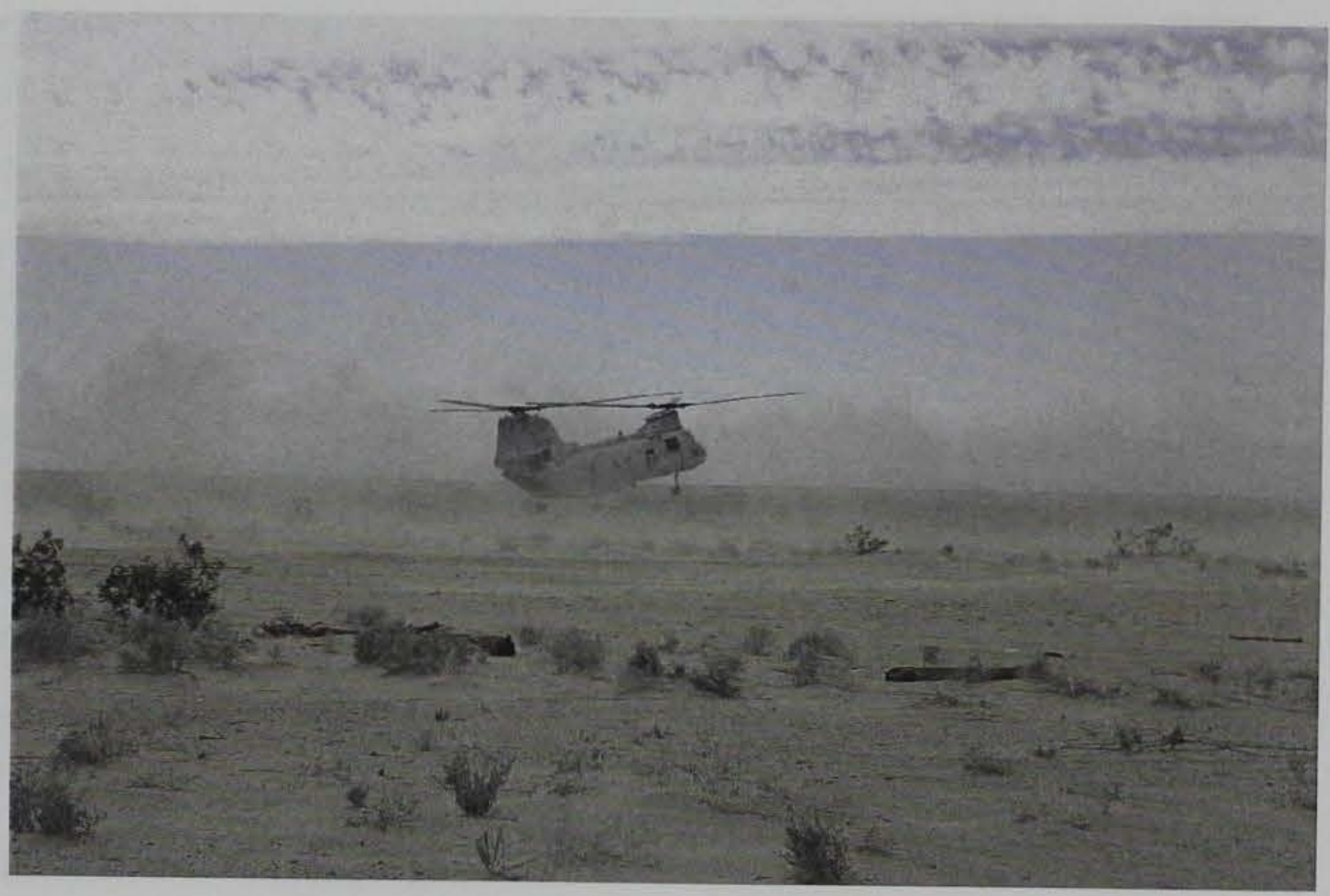

Photo 54. $\mathrm{CH}-46$ operations on Helipad 15 (EnviroKleen A) on 18 February 2004 


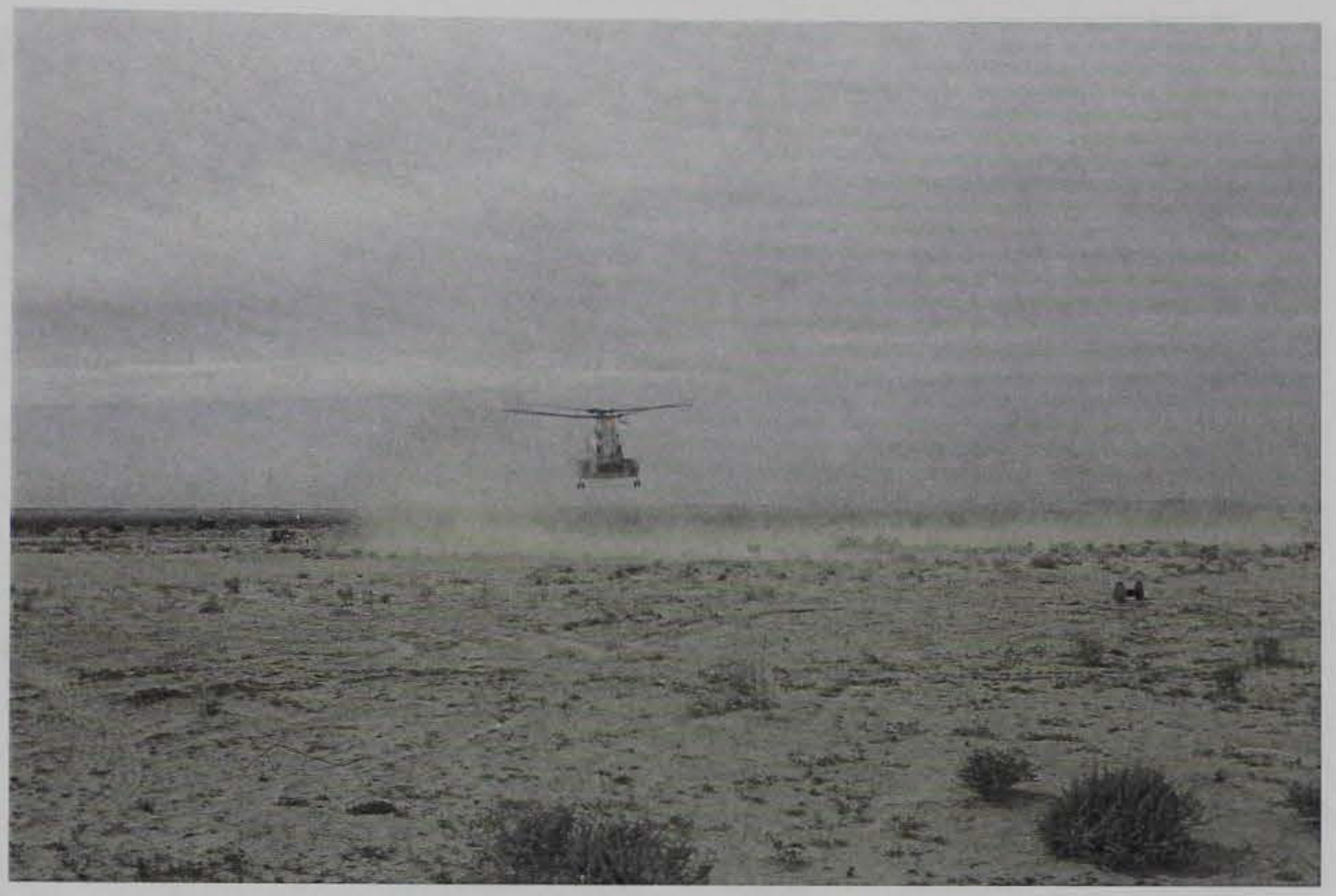

Photo 55. CH-46 operations on Helipad 16 (Soil-Sement) on 18 February 2004

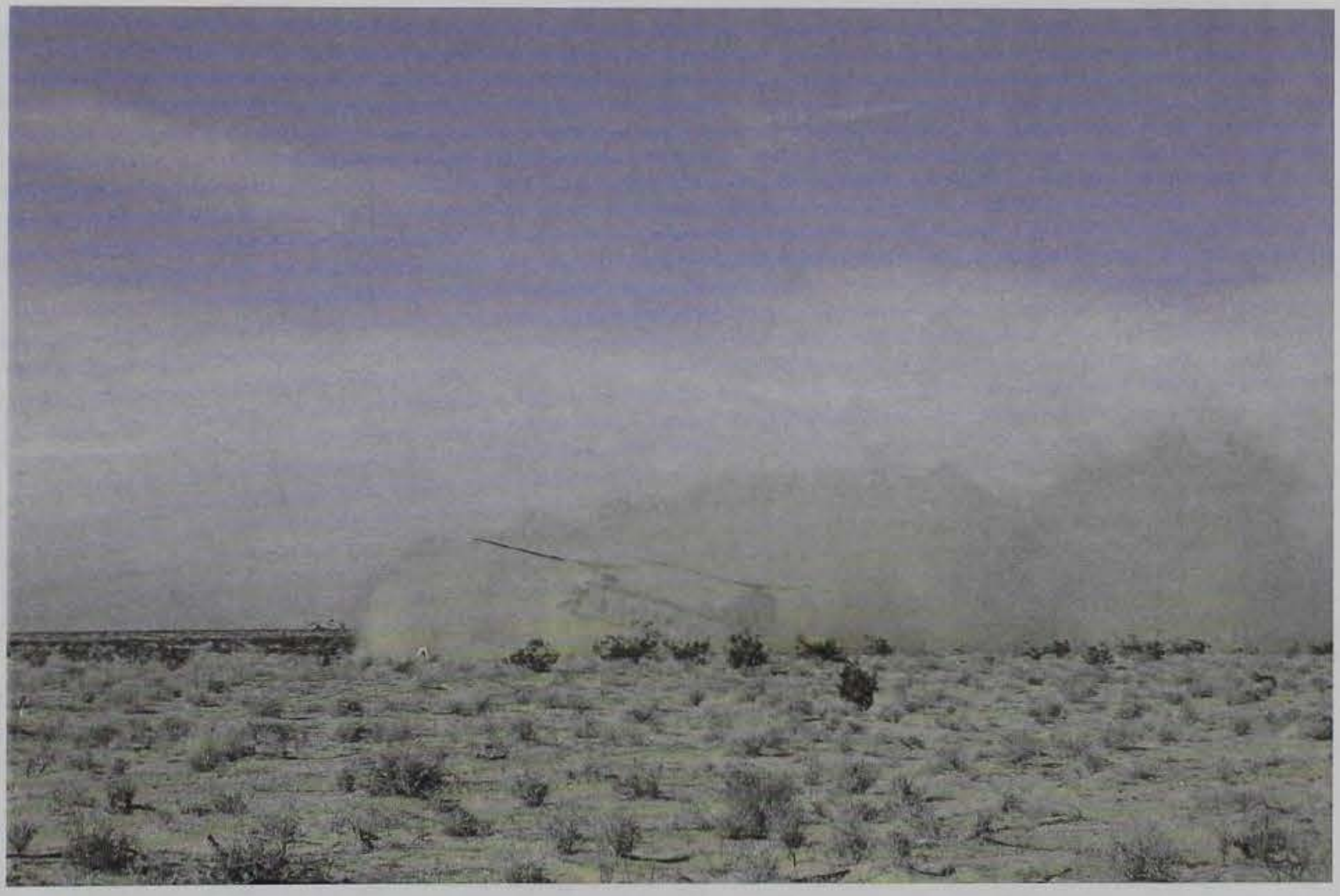

Photo 56. $\quad \mathrm{CH}-46$ operations on Helipad 17 (Dustac B) on 18 February 2004 


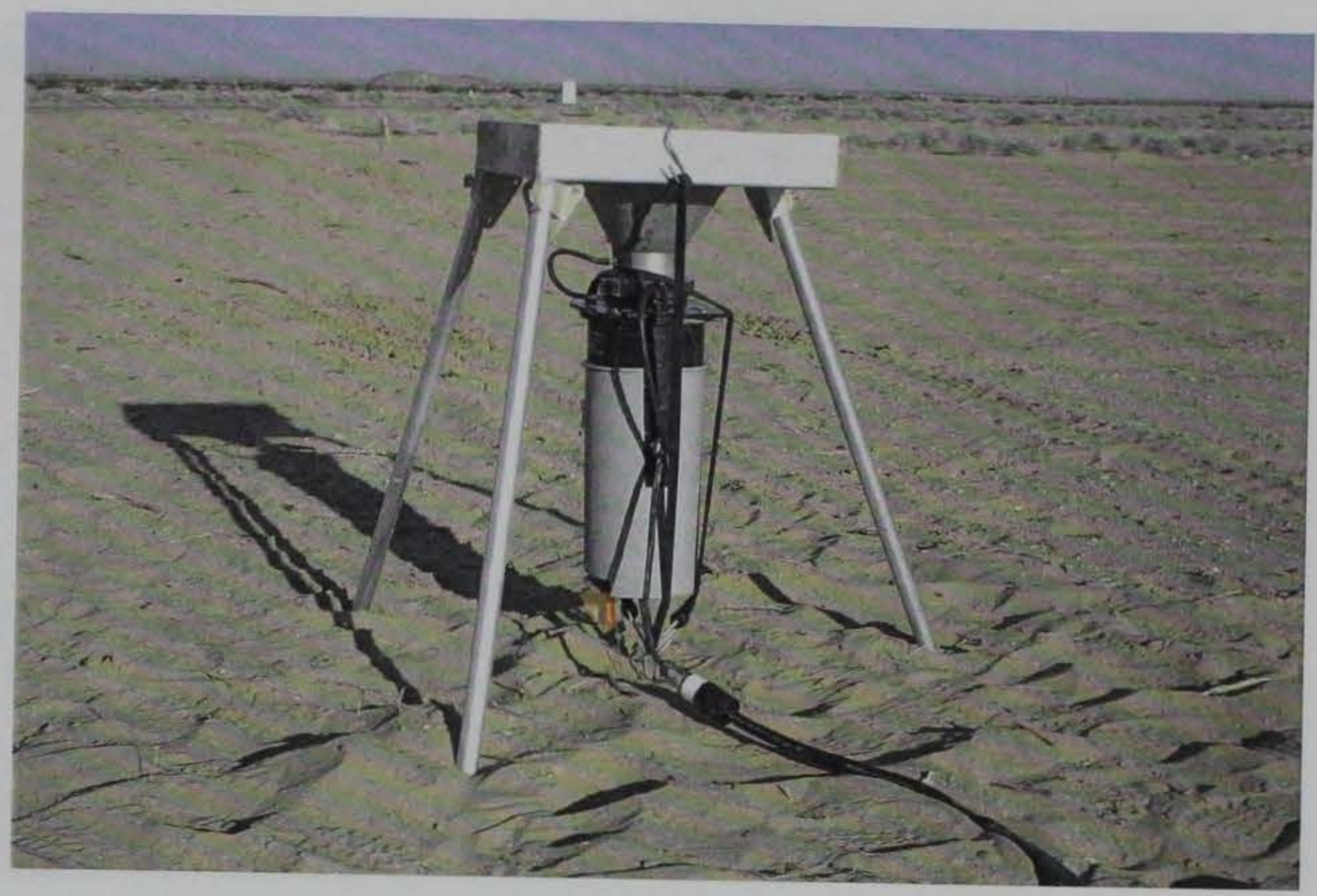

Photo 57. Close-up of stationary dust collector

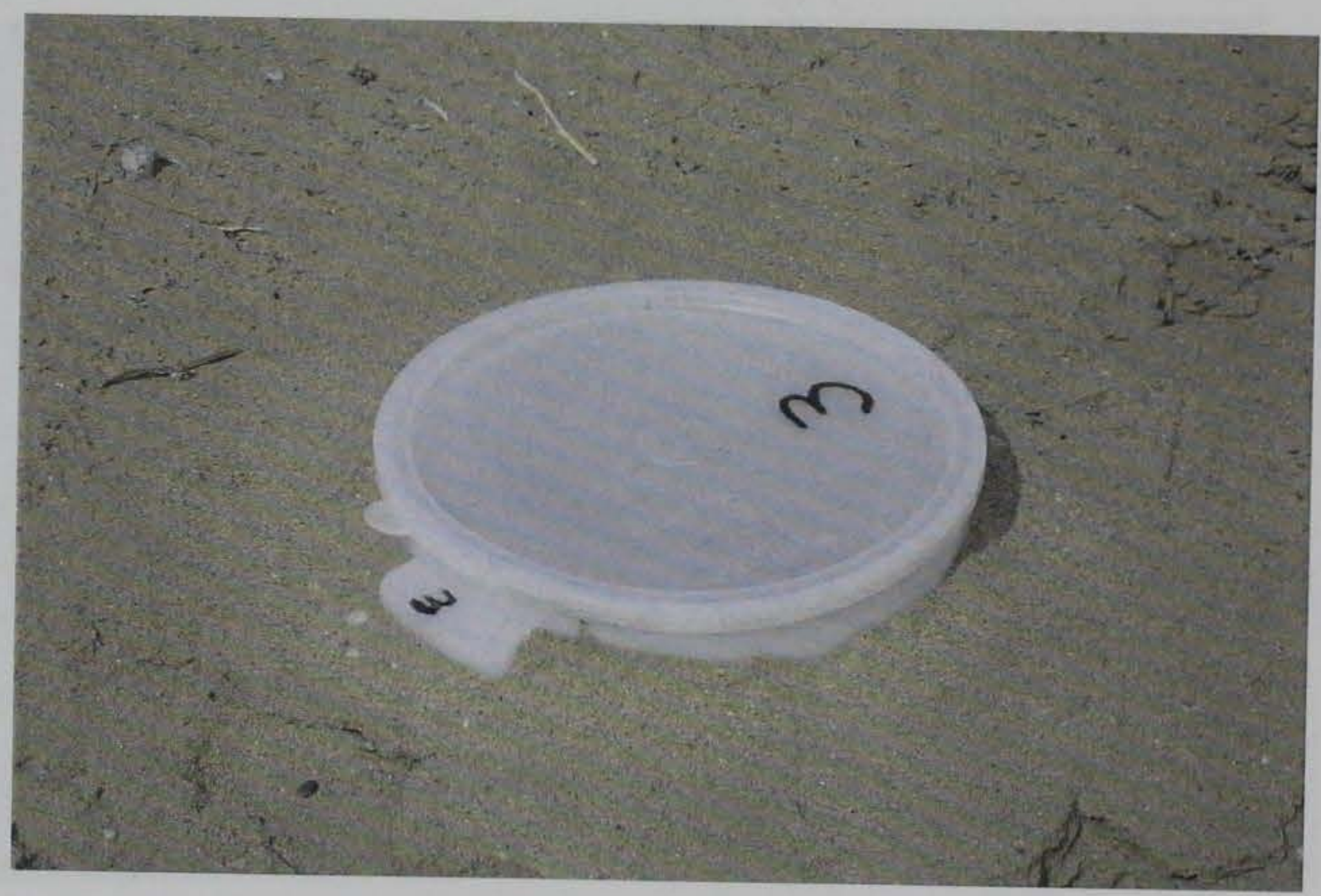

Photo 58. Close-up of gravity bucket for dust collection 


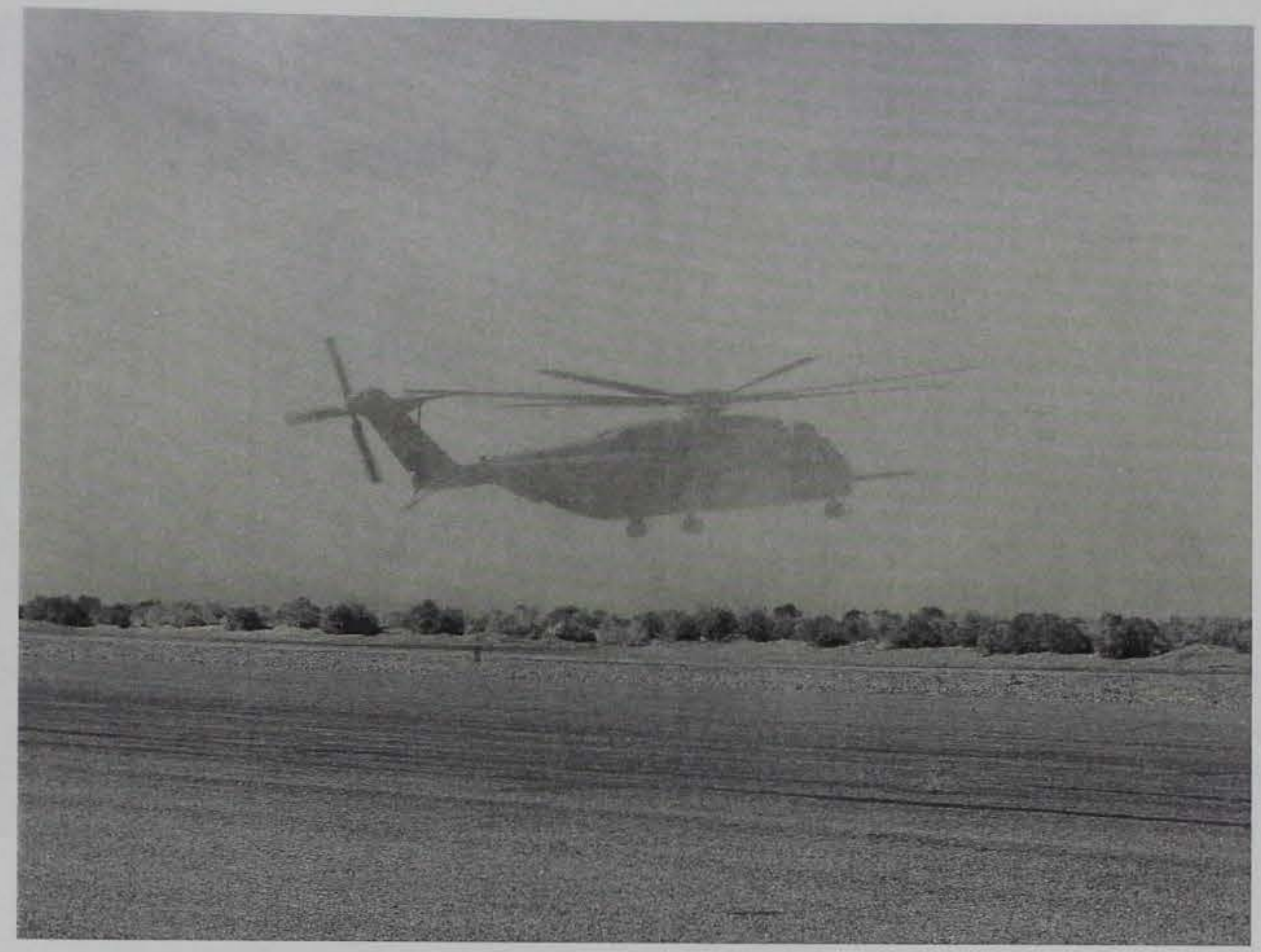

Photo 59. $\mathrm{CH}-53$ operations on Helipad 18 (untreated control) on 19 February 2004

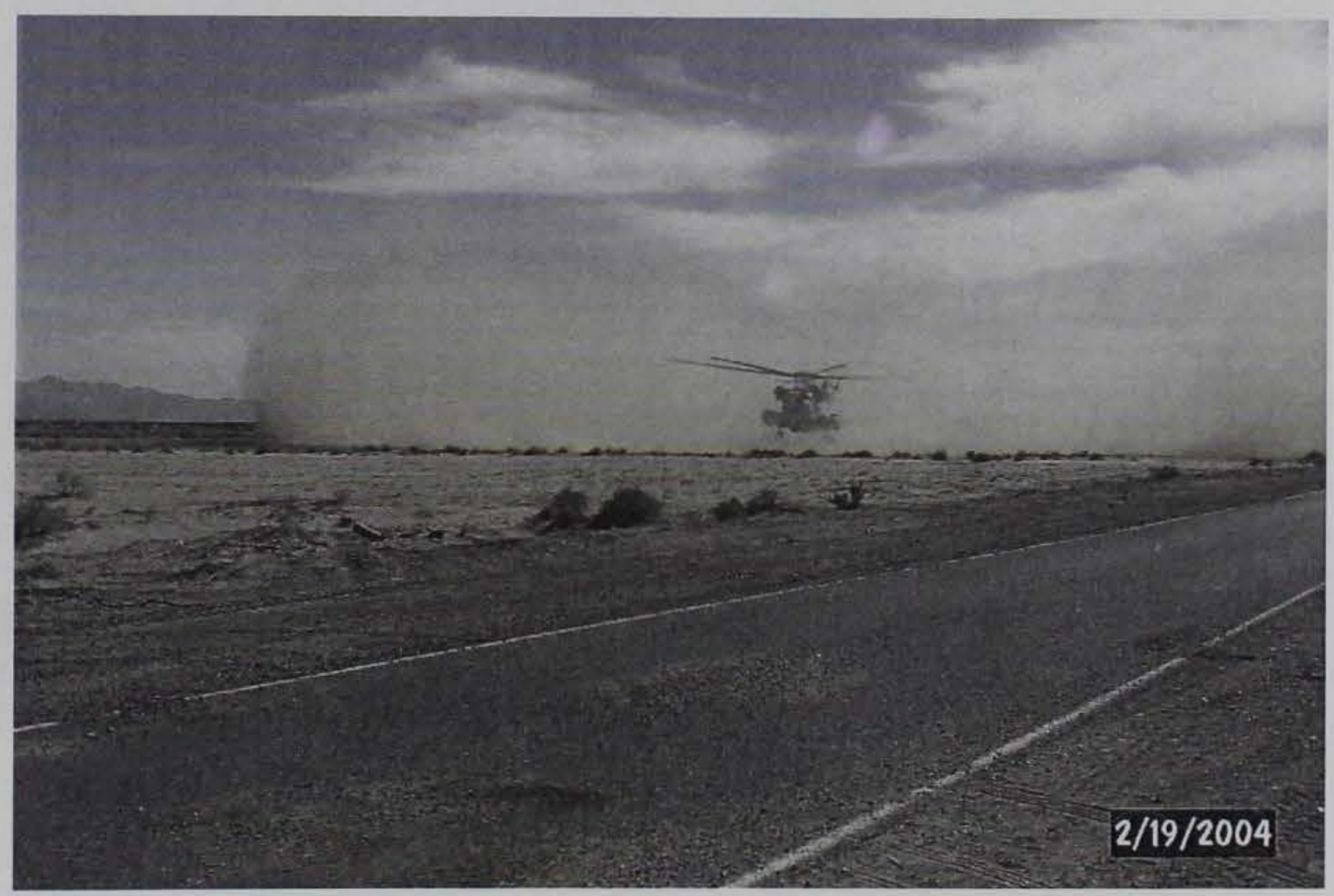

Photo 60. CH-53 operations on Helipad 1 (PolyPius 100) on 19 February 2004 


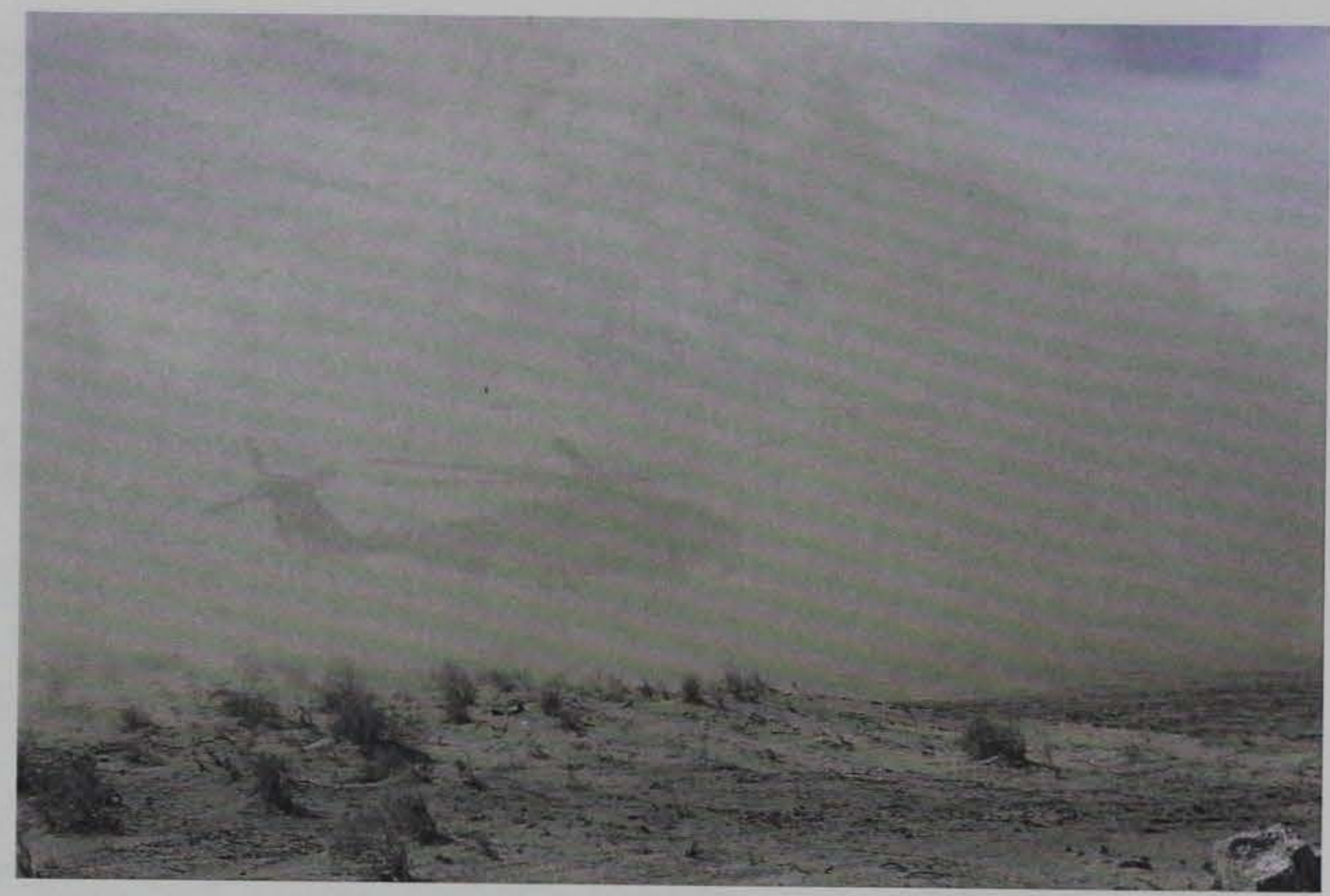

Photo 61. $\mathrm{CH}-53$ operations on Helipad 2 (PolyPlus) on 19 February 2004

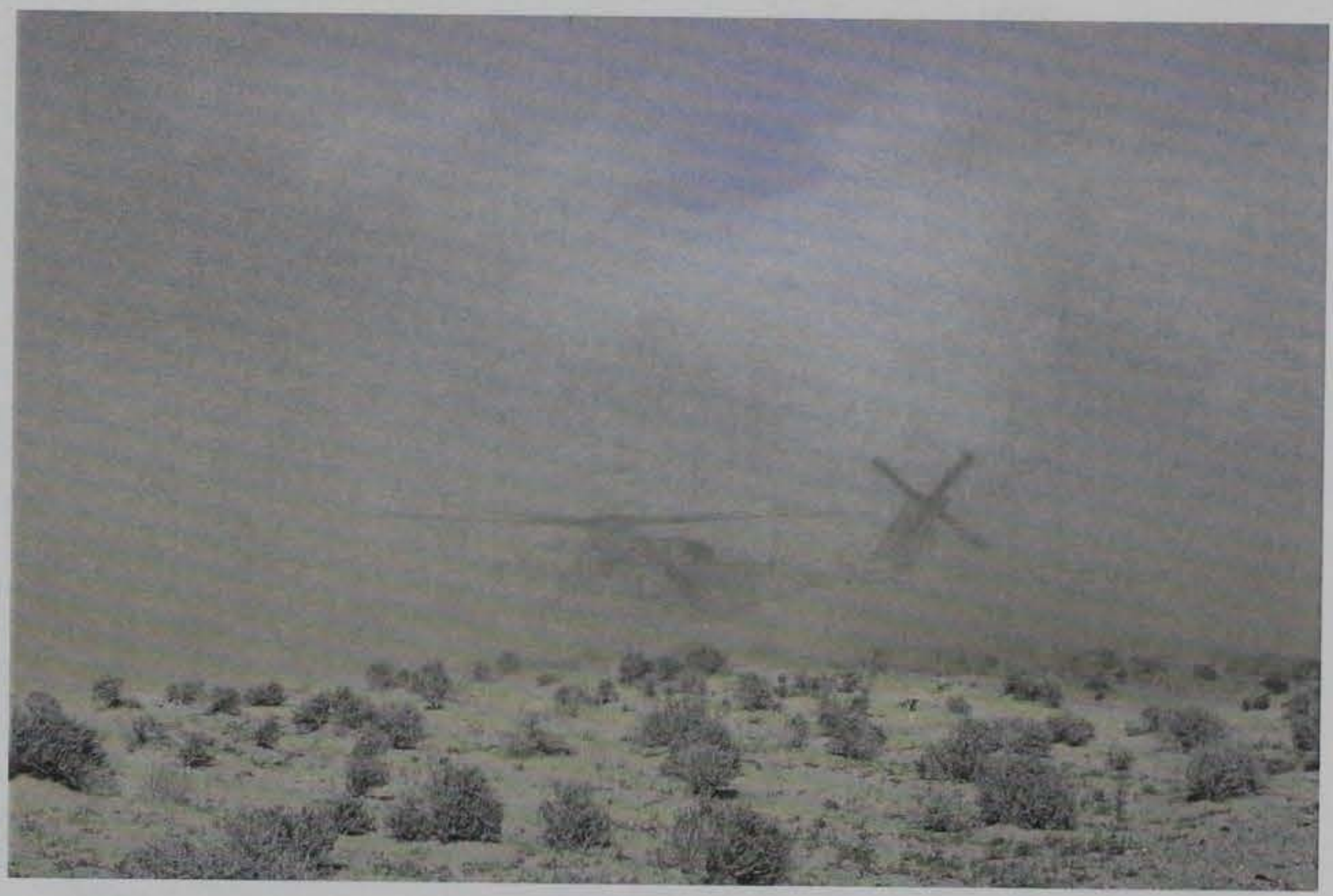

Photo 62. CH-53 operations on Helipad 3 (Tri-PAM) on 19 February 2004 


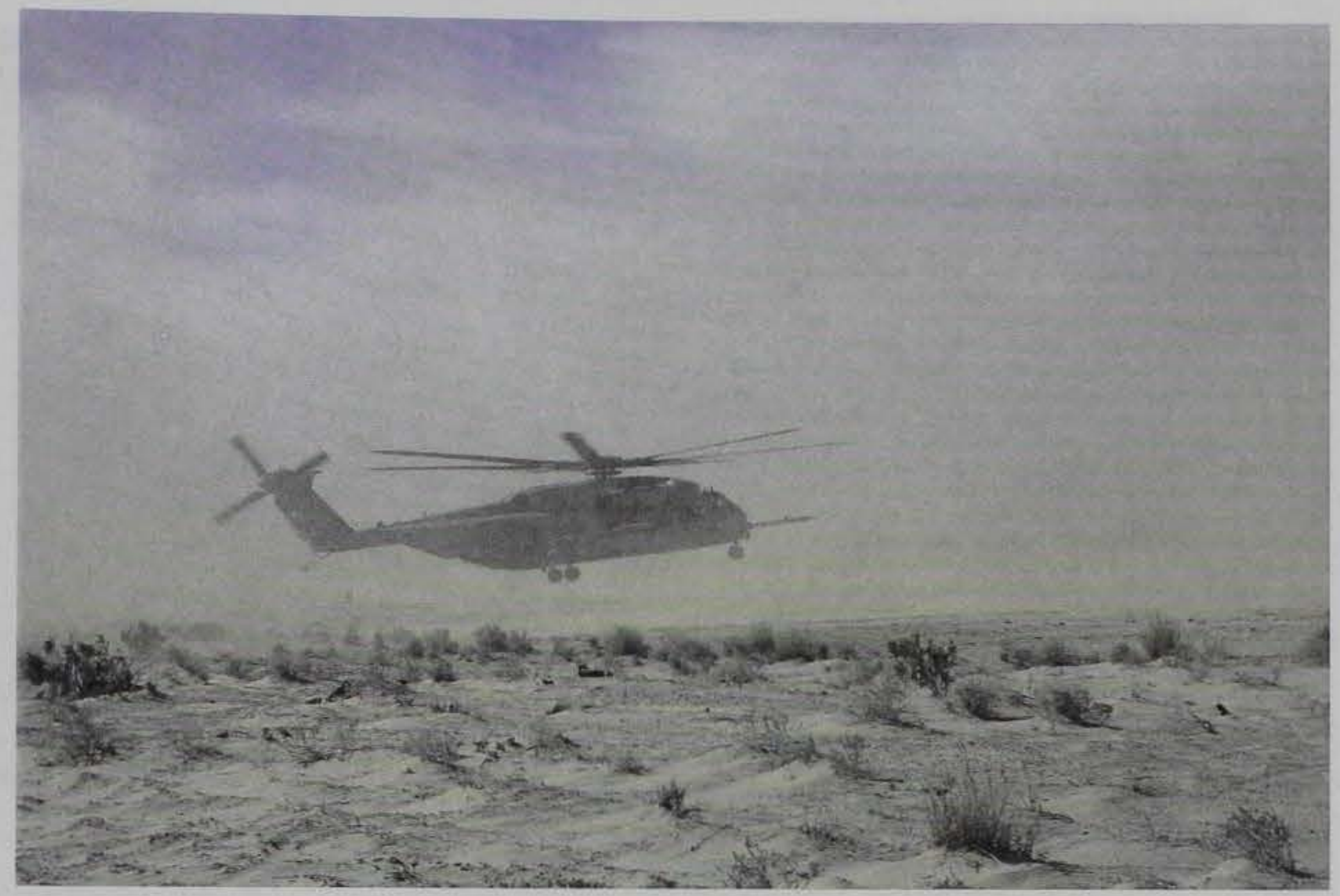

Photo 63. CH-53 operations on Helipad 4 (Envirotac II A) on 19 February 2004

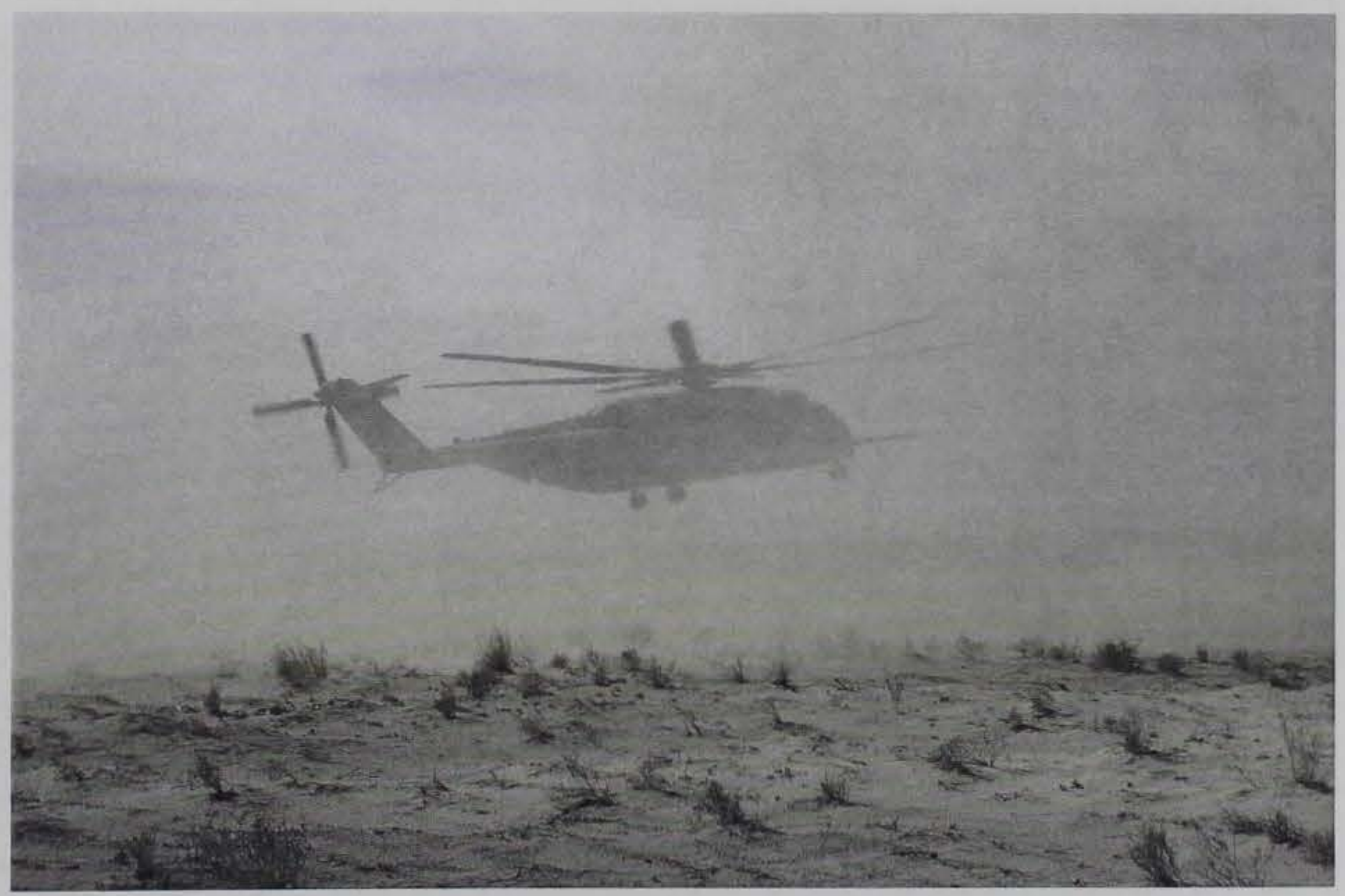

Photo 64. CH-53 operations on Helipad 5 (Soiltac A) on 19 February 2004 


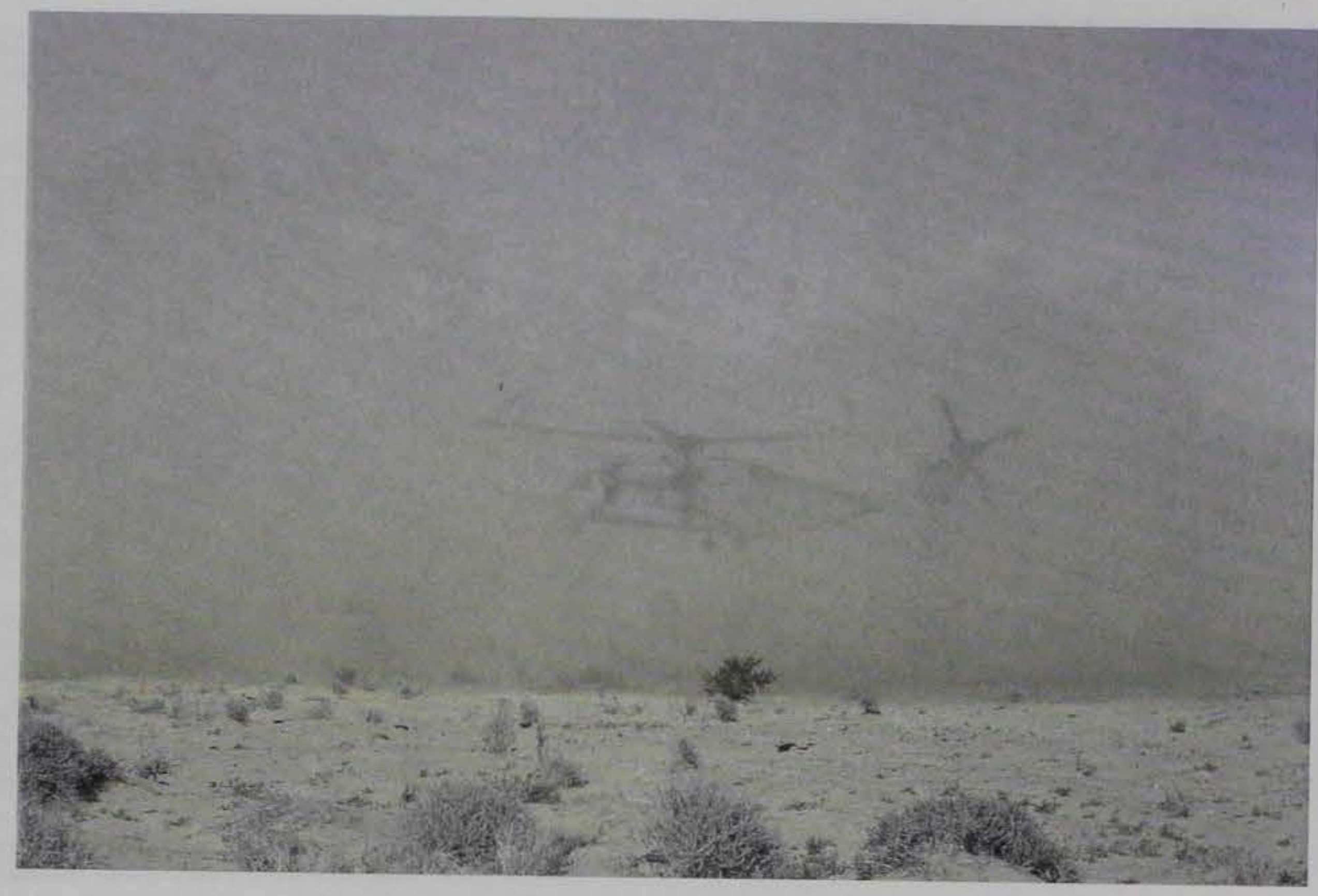

Photo 65. CH-53 operations on Helipad 6 (Soiltac B) on 19 February 2004

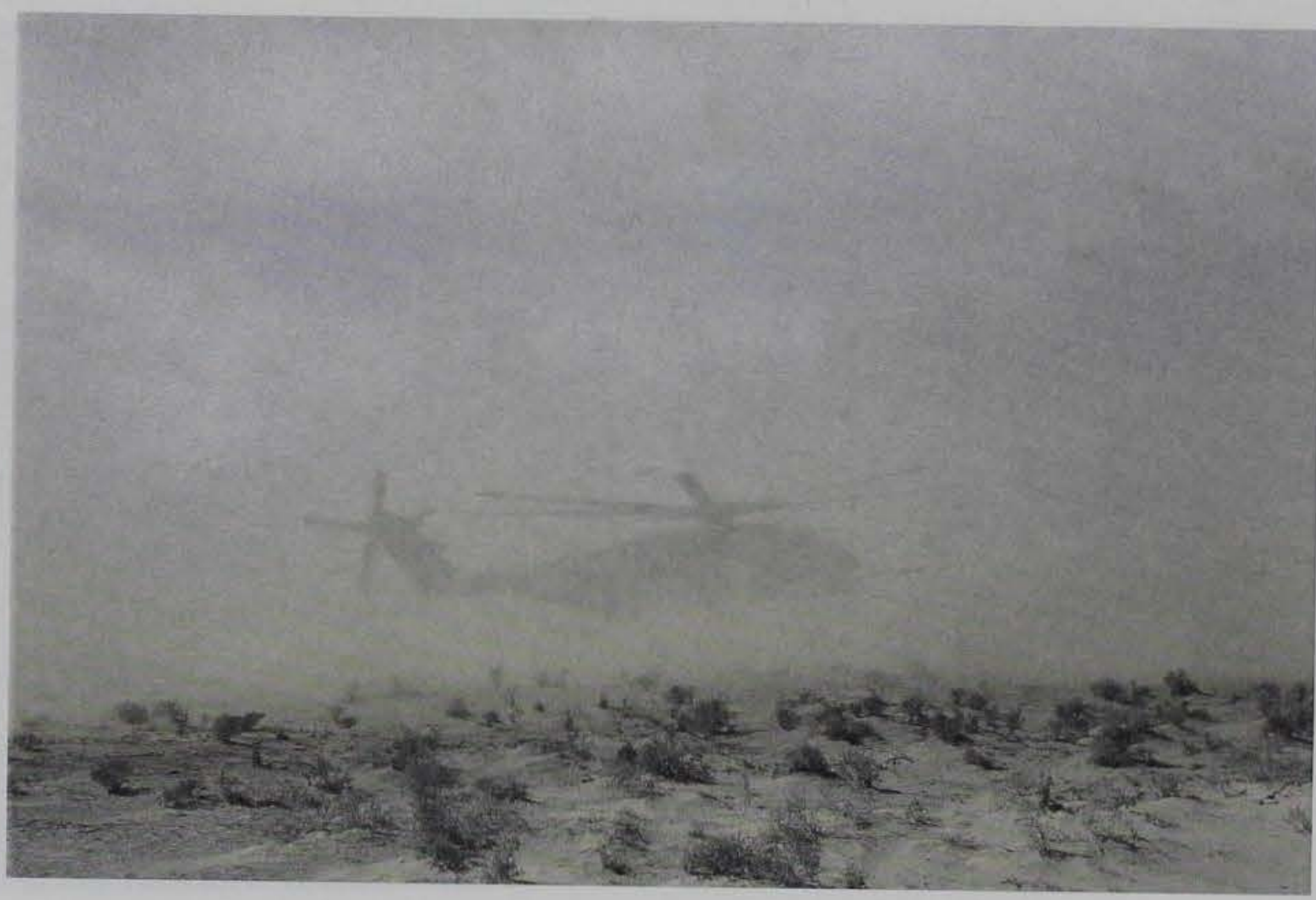

Photo 66. CH-53 operations on Helipad 7 (Envirotac II B) on 19 February 2004 


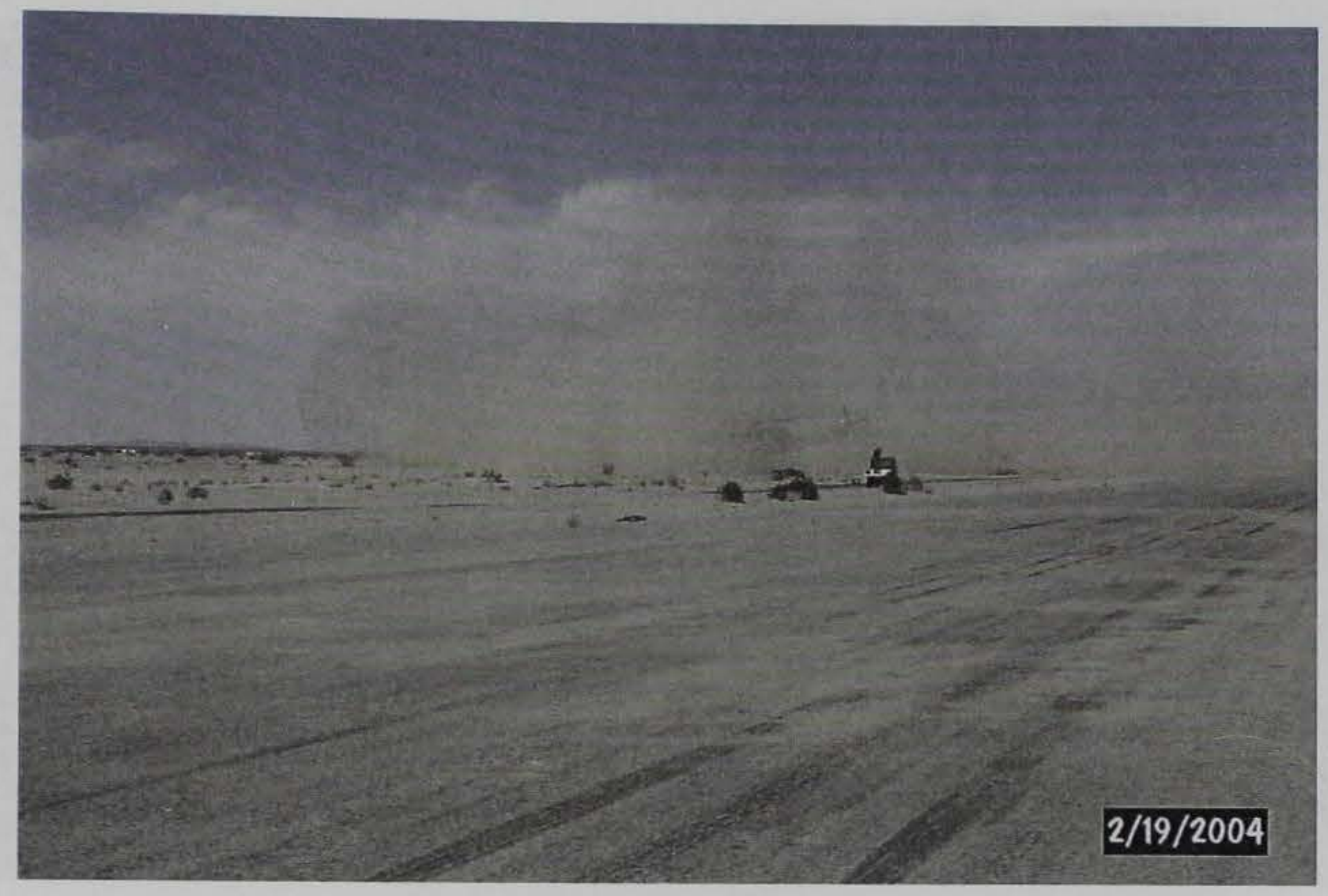

Photo $67 . \quad \mathrm{CH}-53$ operations on Helipad 8 (ECO 110) on 19 February 2004

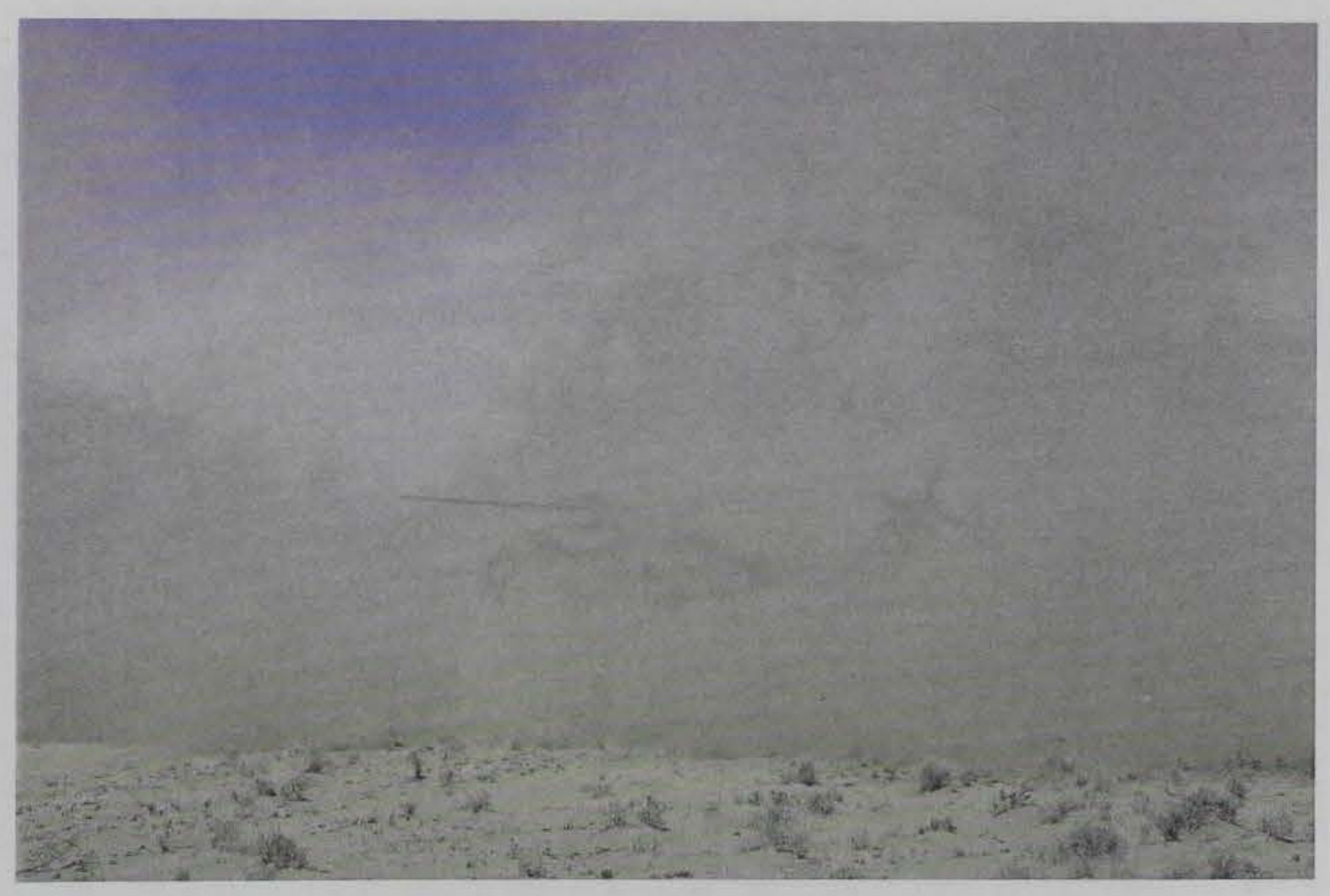

Photo 68. CH-53 operations on Helipad 9 (LDC) on 19 February 2004 


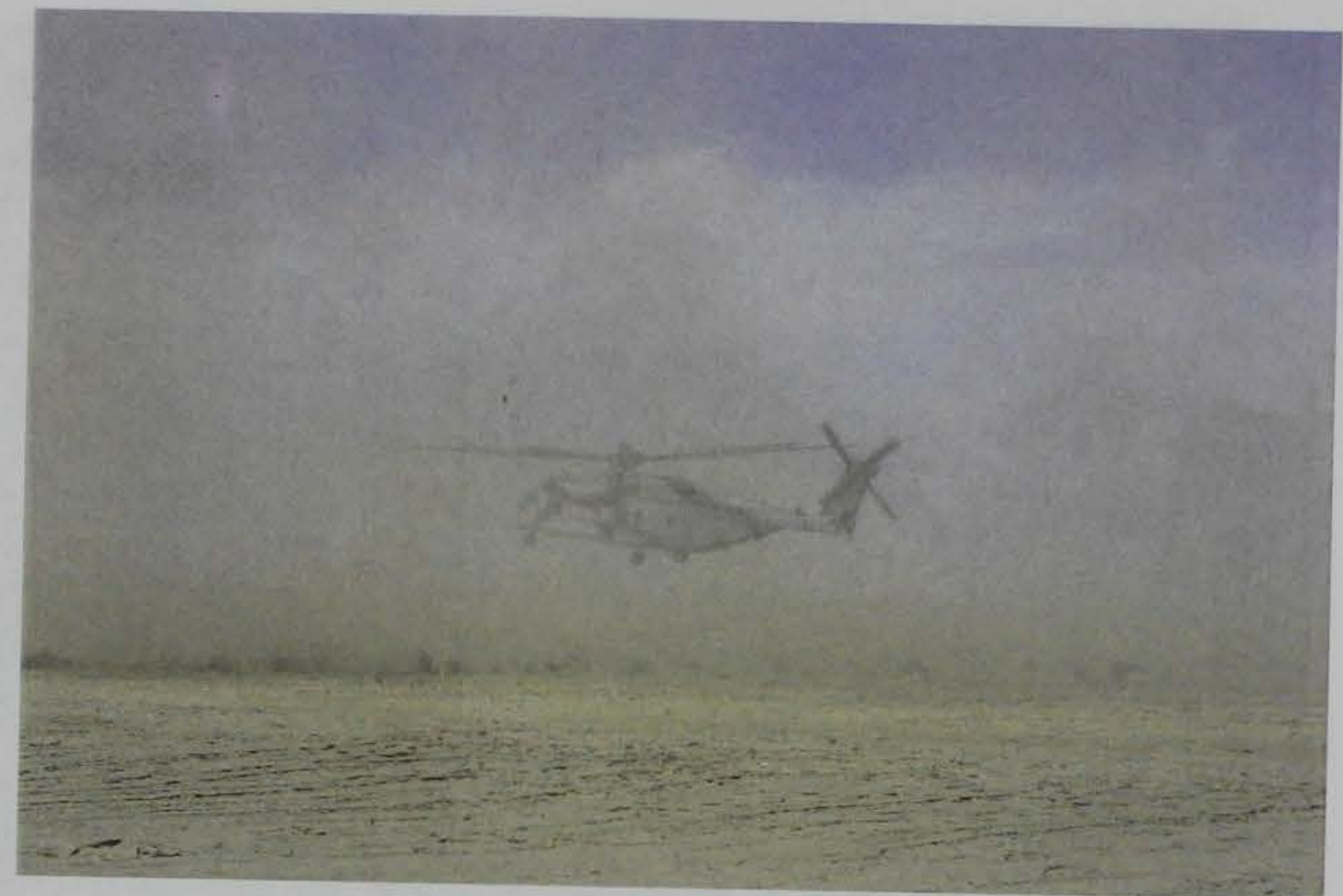

Photo 69. $\mathrm{CH}-53$ operations on Helipad 13 (EnviroKleen B) on 19 February 2004

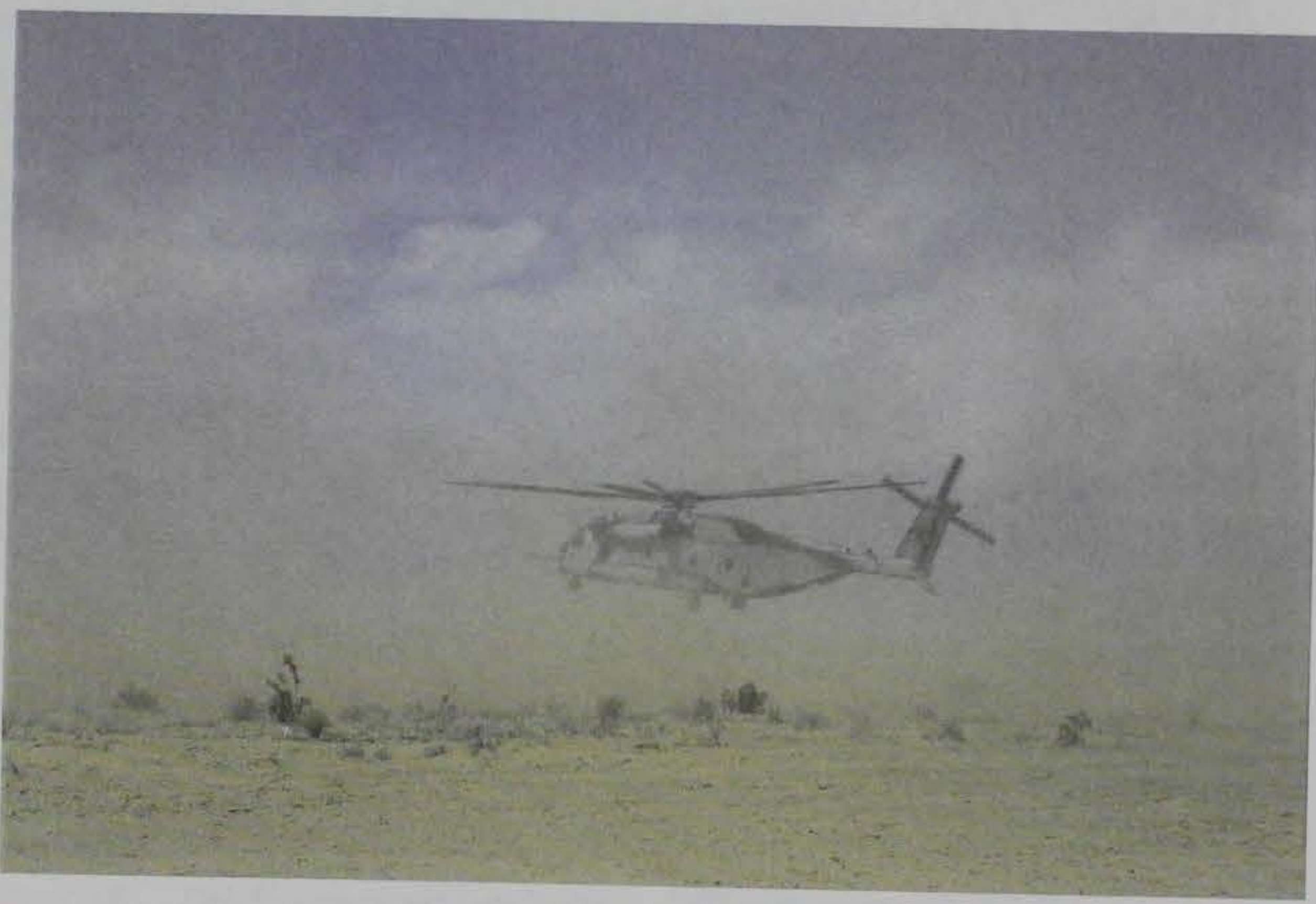
Photo 70. $\mathrm{CH}-53$ operations on Helipad 15 (EnviroKleen A) on 19 February
2004 


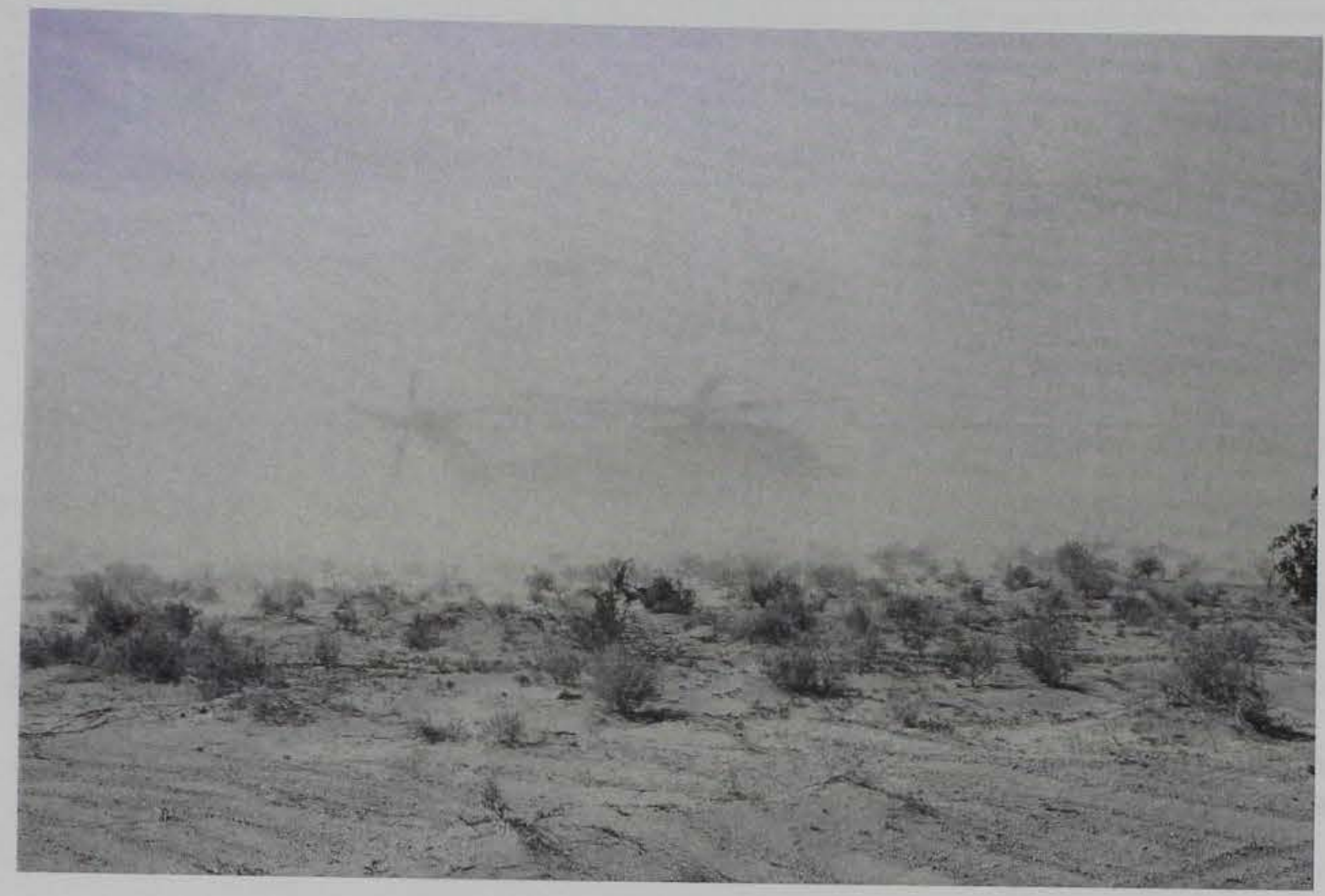

Photo 71. CH-53 operations on Helipad 16 (Soil-Sement) on 19 February 2004

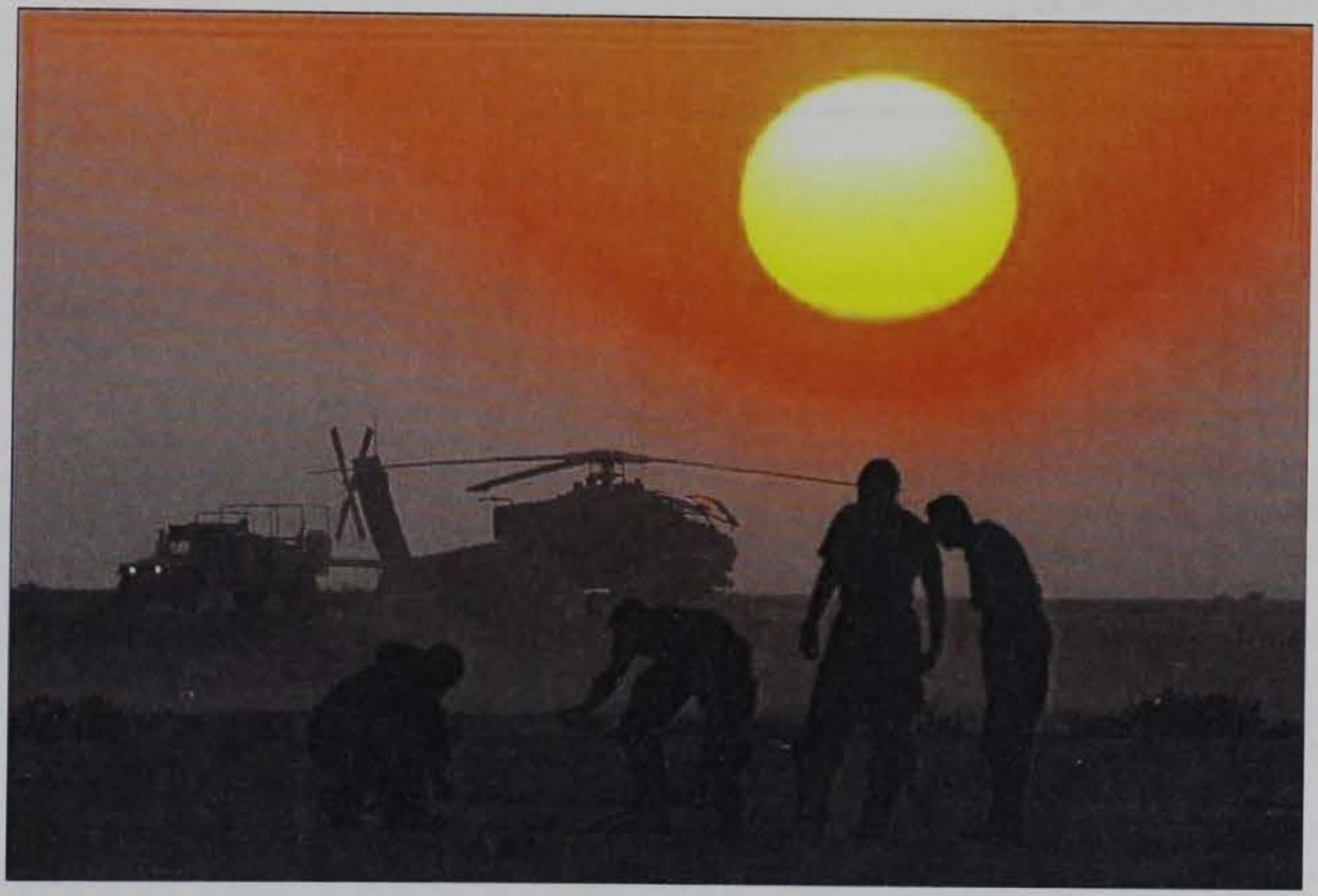

Photo 72. Real world FARP preparation 


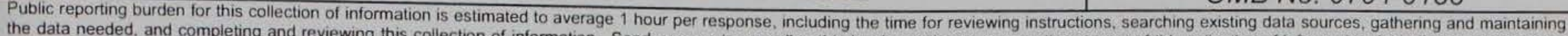

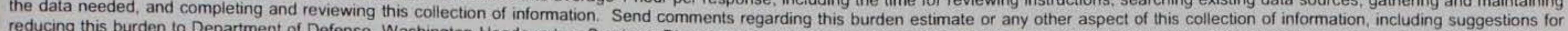

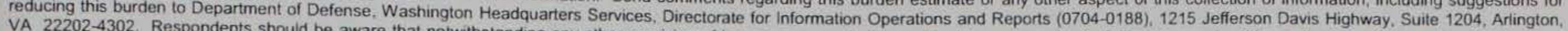

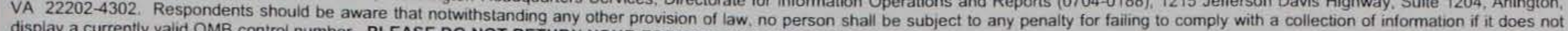

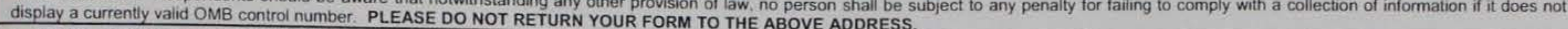
1. REPORT DATE (DD-MM-YYYY)
2. REPORT TYPE

September 2004

Final report

\section{TITLE AND SUBTITLE}

Evaluation of Expedient Methods for Mitigating Dust on Helipads

3. DATES COVERED (From - To)

5a. CONTRACT NUMBER

5b. GRANT NUMBER

5c. PROGRAM ELEMENT NUMBER

\section{AUTHOR(S)}

Jeb S. Tingle, Andrew Harrison, John F. Rushing

5d. PROJECT NUMBER

5e. TASK NUMBER

5f. WORK UNIT NUMBER

8. PERFORMING ORGANIZATION REPORT NUMBER

7. PERFORMING ORGANIZATION NAME(S) AND ADDRESS(ES)

Geotechnical and Structures Laboratory

U.S. Army Engineer Research and Development Center

ERDC/GSL TR-04-10

3909 Halls Ferry Road, Vicksburg, MS 39180-6199

9. SPONSORING / MONITORING AGENCY NAME(S) AND ADDRESS(ES)

10. SPONSOR/MONITOR'S ACRONYM(S)

Headquarters, U.S. Marine Corps Systems Command

2200 Lester Street, Quantico, VA 22134-6050

11. SPONSOR/MONITOR'S REPORT

NUMBER(S)

12. DISTRIBUTION / AVAILABILITY STATEMENT

Approved for public release; distribution is unlimited.

\section{SUPPLEMENTARY NOTES}

\section{ABSTRACT}

The U.S. Army Engineer Research and Development Center (ERDC) was tasked by the Marine Corps Systems Command to develop two dust control systems, one for expeditionary use on Forward Area Refueling Points (FARPs) and one for sustainment use on roads and other large area applications. The project consisted of the evaluation of various dust palliatives and application equipment under controlled laboratory conditions and during field tests. The products of this effort include equipment recommendations, palliative recommendations, and complete application guidance. This report addresses testing performed to evaluate commercial palliatives and palliative distribution systems for expeditionary use in constructing and maintaining FARP sites. Eighteen helipads were constructed at Marine Corps Air Station Yuma using both experimental and commercial palliatives for dust abatement. The application methods were principally topical (spray-on) and expeditionary in nature. Each helipad was subjected to $\mathrm{CH}-46$ rotary-wing aircraft traffic, and selected helipads were subjected to $\mathrm{CH}-53$ traffic. The helipads were evaluated based upon effectiveness in controlling dust, durability, foreign object damage (FOD) potential, and overall surface condition. Pertinent conclusions from the testing conducted are noted, and recommendations for selecting dust abatement methods and materials are provided.

\begin{tabular}{|c|c|c|c|c|c|}
\hline \multicolumn{2}{|l|}{$\begin{array}{l}\text { 15. SUBJECT TERMS } \\
\text { Aviation support } \\
\text { Dust }\end{array}$} & $\begin{array}{l}\text { Dust abatement } \\
\text { Dust control } \\
\text { Dust mitigation } \\
\end{array}$ & \multicolumn{3}{|c|}{ Helipad } \\
\hline \multicolumn{3}{|c|}{ 16. SECURITY CLASSIFICATION OF: } & $\begin{array}{l}\text { 17. LIMITATION } \\
\text { OF ABSTRACT }\end{array}$ & $\begin{array}{l}\text { 18. NUMBER } \\
\text { OF PAGES }\end{array}$ & $\begin{array}{l}\text { 19a. NAME OF RESPONSIBLE } \\
\text { PERSON }\end{array}$ \\
\hline $\begin{array}{l}\text { a. REPORT } \\
\text { UNCLASSIFIED }\end{array}$ & $\begin{array}{l}\text { b. ABSTRACT } \\
\text { UNCLASSIFIED }\end{array}$ & $\begin{array}{l}\text { c. THIS PAGE } \\
\text { UNCLASSIFIED }\end{array}$ & & 92 & $\begin{array}{l}\text { 19b. TELEPHONE NUMBER (include } \\
\text { area code) }\end{array}$ \\
\hline
\end{tabular}

